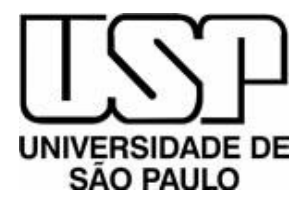

Instituto de Física Instituto de Química Instituto de Biociências Faculdade de Educação

\section{UA \\ UNIVERSIDAD AUTONOMA \\ DE MADRID}

Facultad de Formación de Profesorado y Educación

Departamento de Didáctica y Teoría de la Educación

\title{
SABERES DOCENTES DE ARGUMENTAÇÃO: DINÂMICAS DE DESENVOLVIMENTO NA FORMAÇÃO INICIAL DE PROFESSORES DE CIÊNCIAS
}

\section{Ariane Baffa Lourenço}

Orientadora: Profa. Dra. Maria Lucia Vital dos Santos Abib Universidade de São Paulo

Orientador: Prof. Dr. Francisco Javier Murillo Torrecilla Universidad Autónoma de Madrid

São Paulo, 2013 


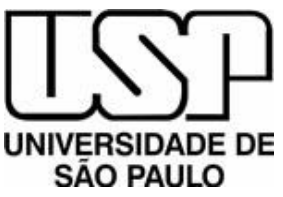

Instituto de Física

Instituto de Química

Instituto de Biociências

Faculdade de Educação

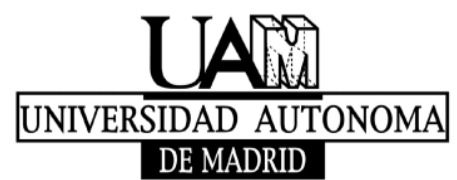

Facultad de Formación de Profesorado y Educación

Departamento de Didáctica y Teoría de la Educación

\section{SABERES DOCENTES DE ARGUMENTAÇÃO: DINÂMICAS DE DESENVOLVIMENTO NA FORMAÇÃO INICIAL DE PROFESSORES DE CIÊNCIAS}

\section{Ariane Baffa Lourenço}

Tese apresentada ao Instituto de Física, ao Instituto de Química, ao Instituto de Biociências e a Faculdade de Educação da Universidade de São Paulo para a obtenção do título de Doutora em Ciências: Área de Concentração Ensino de Física e para a Facultad de Formación de Professorado da Universidad Autónoma de Madrid para a obtenção do título de Doutora em Educação.

São Paulo, 2013 
Autorizo a reprodução e divulgação total ou parcial deste trabalho, por qualquer meio convencional ou eletrônico, para fins de estudo e pesquisa, desde que citada a fonte.

FICHA CATALOGRÁFICA

Preparada pelo Serviço de Biblioteca e Informação do Instituto de Física da Universidade de São Paulo

Lourenço, Ariane Baffa

Saberes docentes de argumentação: dinâmicas de desenvolvimento na formação inicial de professores de ciências. - São Paulo, 2013.

Tese (Doutorado) - Universidade de São Paulo.

Faculdade de Educação, Instituto de Física, Instituto de Química

e Instituto de Biociências

Orientadores: Prof ${ }^{a}$ Dra ${ }^{\text {a }}$ Maria Lucia Vital dos Santos Abib Universidade de São Paulo - Faculdade de Educação

Prof ${ }^{\circ}$ Dro Francisco Javier Murillo Torrecilla -

Universidade Autónoma de Madrid - Facultad de Formación de Profesorado y Educación

Área de Concentração: Ensino de Ciências

Unitermos: 1. Ensino; 2. Formação de professores; 3. Ciência - Ensino USP/IF/SBI-068/2013 


\section{AGRADECIMENTOS}

A Deus por ter me proporcionado todas as condições necessárias para a realização deste trabalho e me guiado na caminhada.

À Professora Maria Lucia pelo apoio, carinho e dedicação a minha formação profissional e pessoal. Obrigada por aceitar-me nesta linda família que é seu grupo de investigação e por sempre com toda a paciência entender os meus momentos, apoiar-me nas minhas decisões e mostrar-me os melhores caminhos a serem trilhados. Querida professora, sou e serei eternamente grata por ajudar-me na elaboração dos meus saberes docentes $:-$. A senhora foi partícipe fundamental na realização deste sonho. Obrigada!

Ao Professor Francisco Javier Murillo Torrecilla, por aceitar-me no GICE (Grupo de Investigação para la Justicia Social) para realizar o meu doutorado co-tutela e por todas as contribuições ao longo deste trabalho. Foi um imenso prazer trabalhar com o senhor, aprendi muito no período que estive em Madri e por nossas conversas via email!

Ao Professor Hernandes. Professor, palavras são poucas para agradecer tudo o que o senhor fez por mim e me ensinou. A nossa parceria desde a minha graduação ajudoume a crescer tanto no âmbito pessoal como profissional. O senhor me deu oportunidades, desafios e sempre confiou em mim no desenvolvimento de diferentes trabalhos no LaDiC (Laboratório de Difusão Científica). Sou imensamente grata, pois se hoje finalizo mais uma etapa profissional da minha vida, saiba que o senhor foi em muitos momentos meu alicerce para que isto acontecesse. Meu querido professor/diretor o meu mais profundo e eterno agradecimento.

À Professora Salete Linhares Queiroz. Professora, a minha aprendizagem contigo iniciou-se na minha graduação e perpassou todo o meu doutorado. Meu conhecimento sobre formação inicial de professores deve-se também à senhora que 
muito me ensinou com sua dedicação e competência na formação de docentes diferenciados. Obrigada!

Ao Professor Manuel Santiago pelas sugestões ao meu trabalho, pelo apoio nos trâmites do meu doutorado co-tutela e pela amizade.

Às Professoras Lucia Helena Sasseron e Elsa Garrido pelas valiosas contribuições no meu exame de qualificação.

Aos professores Juan Guillaron e Luis Mendes por durante os anos em que desenvolvemos nosso projeto Brasil-Cuba termos feito tantas trocas de experiências e conhecimento e por sempre me apoiarem.

À professora Glaucia Gruninger Gomes Costa, pelo apoio nos diferentes momentos da elaboração desta tese e por tantas conversas na busca de melhorias do ensino público.

A minha família por me apoiarem no meu processo educativo e por me darem o apoio necessário nos meus mais diferentes desejos. Agradeço em especial ao meu Bibo Pai que nestes catorze anos que moramos juntos sempre cuidou da sua Biba Filha $:$ com seu amor incondicional. Obrigada pelos chazinhos matinais! Talvez não saiba, mas eles em muitos momentos foram a força do dia.

A minha Gor obrigada por sempre estar aqui, cuidando de mim e me protegendo. Se me perguntarem em outra vida quem quero como irmã não tenha dúvida que escolherei você.

Ao Stefan. Obrigada por transformar momentos difíceis em situações suaves, por me ouvir, por se preocupar e me dar todo o apoio, por mesmo longe estar sempre perto de mim. Obrigada! 
À Valdeci minha amiga de longa data. Muito obrigada pelas inúmeras conversas, passeios, viagens e pelo apoio nas horas mais difíceis.

À Roseli Buonaroti. Pepepe não tenho palavras para agradecer tudo o que você fez e é para mim. Amiga, tenha certeza que nesta caminhada você foi em muitos momentos os meus pés, o meu gps e o meu porto seguro. Pepepe saiba que você é uma das pessoas mais importantes na minha vida. Obrigada por tudo!

À professora Solange Rezende por tantas conversas edificantes, por tanto apoio e por sempre transmitir esta serenidade e confiança que tanto nos contagia. Muito obrigada por sempre estar ao meu lado. Você é um exemplo de mulher, professora e amiga.

À Liz Vazquez, minha companheira de república espanhola (:). Você fez mais fácil a minha existência na Espanha, compartilhou comigo novas experiências, dúvidas, tantos passeios, tantos momentos! Tenho muito que te agradecer, pois você foi o apoio fundamental a uma vivência totalmente nova. Sempre recordo "Lejos de los ojos pero cerca del corazón".

À Lilian, por todo o companheirismo e amizade no período em que estive na Espanha e por continuarmos sempre conectadas e amigas ainda que tão distantes geograficamente.

À Zuly, obrigada por me aceitar como sua inquilina $(;)$, a convivência com você foi um presente. Chegar a um país e encontrar você foi um bálsamo. A nossa convivência (Liz, você e Eu) foi agradável e muito divertida. Obrigada!

A todas as pessoas que contribuíram com a minha estadia em Madri, a quem devo muitos momentos de apoio, sejam eles no âmbito profissional ou pessoal. Everardo, Graziela, Hector, Ana Maria, Gabriela, Reyna, Jessica, Adriana e Anita, companheiros do GICE, obrigada. 
À Doutora Maria Inês Basso Bernardi por todo apoio, carinho e confiança desde a época da minha graduação e por sempre acreditar em mim.

À Doutora Elisangela Matias Miranda, nossa que chique hein! minha amiga, companheira de disciplina, de congressos, de viagens, de trabalhos e de crescimento. Obrigada por tanto apoio.

Ao Taiwo Oladeinde obrigada por estar ao meu lado em muitos momentos, por me ensinar muitas coisas e por despertar em mim desejos de mudanças na busca de um ser melhor. Também não poderia deixar de te agradecer pelo apoio constante nas traduções para o inglês $:$. Thank you.

Aos meus amigos Pedro Colombo Junior e Adriana Puglesi companheiros de disciplina, de congressos, de artigos e de muitas discussões edificantes. Pedro, obrigada também por vivenciar comigo tantas histórias hilárias das nossas idas e vindas de São Carlos para São Paulo $(;$.

À Amanda Murgo, minha jornalista preferida rs. Obrigada pelos momentos atenciosos quando mais precisei e por todas as nossas conversas, que perpassavam diferentes âmbitos e tinham como meta sempre nossa evolução.

Aos meus amigos Cris Cammis, Wilson e Ronaldo pelos nossos passeios culturais, gastronômicos e nossos momentos dançantes. Danke pelos momentos de alegria.

Ao Marcos Marques meu companheiro de caminhadas dominicais.

À Erica Regina Signini secretária do Grupo de pesquisa Crescimento de Cristais e Materiais Cerâmicos, obrigada por sempre estar disposta a ajudar-me de forma carinhosa e dedicada.

Ao Thomas e Ellen secretários do Programa de Pós-Graduação Interunidades no Ensino de Ciências obrigada por me ajudarem de maneira ímpar e competente em 
todos os trâmites desse doutorado Co-tutela. Foram muitos documentos indo e vindo, mas conseguimos. Obrigada!

A todos os licenciandos que fizeram parte desta pesquisa.

Aos meus irmãos acadêmicos Alexandre, Beatriz, Marta, Nizete, Yara, Leonardo, Helder e Monica, por tantas trocas de experiências e sugestões ao meu trabalho. Muito aprendi com os trabalhos de vocês. Obrigada!

A todos os integrantes do Grupo de pesquisa Crescimento de Cristais e Materiais (CCMC) por me permitirem fazer deste grupo a minha segunda casa. Agradeço em especial aos integrantes mais antigos: Inês, Geraldo Frigo, Manoel Roncon, Cássio, Sergio Marcondes e Luis Caraschi, vocês me ajudaram em diferentes momentos da minha formação.

A todos os alunos de iniciação científica, estagiários e alunos de Pré-Iniciação Científica que estão ou passaram pelo nosso amado LADIC (Laboratório de Difusão Científica-CCMC). Cada um contribuiu direta ou indiretamente ao meu desenvolvimento como pesquisadora.

A todos os integrantes do Centro Espírita Paz e Harmonia, por serem o apoio espiritual tão necessário e fundamental em qualquer etapa da vida das pessoas. Obrigada!

A todas as pessoas que contribuíram e estiveram presente nesta jornada, as quais pelo amor ou pela dor me impulsionaram na busca de uma melhoria nos diferentes aspectos da minha vida. O meu mais profundo agradecimento.

Ao Grupo Amor em Gotas que nestes dez anos que estamos juntos me ensinou muito. A cada domingo que vamos à Santa Casa sinto a minha Fé, Esperança e Amor renovados e faço minhas as palavras do Gonzaguinha "Eu fico com a pureza da resposta das crianças: É a vida, é bonita, e é bonita". 
... O professor trouxera de casa os nossos trabalhos escolares e, chamando-nos um a um, devolvia-os com o seu ajuizamento. Em certo momento me chama e, olhando ou re-olhando o meu texto, sem dizer palavra, balança a cabeça numa demonstração de respeito e de consideração. O gesto do professor valeu mais que a nota dez que atribuiu à minha redação. O gesto do professor me trazia confiança ainda obviamente desconfiada de que era possível trabalhar e produzir. De que era possível confiar em mim, mas que seria tão errado confiar além dos limites quanto errado estava sendo não confiar.

Paulo Freire ${ }^{1}$

1 In: FREIRE, Paulo. Pedagogia da Autonomia. Saberes necessários à prática educativa. $7^{\text {a }}$ ed. São Paulo: Paz e Terra, 1996. 


\section{RESUMO}

LOURENCO, A. B. Saberes Docentes de Argumentação: Dinâmicas de desenvolvimento na formação inicial de professores de Ciências. 2013. 254 f. Tese (Doutorado) - Instituto de Física, ao Instituto de Química, ao Instituto de Biociências e a Faculdade de Educação da Universidade de São Paulo, São Paulo e Facultad de Formación de Professorado da Universidad Autónoma de Madrid, Madrid, 2013.

A formação inicial de professores é um momento de suma importância, pois deve fornecer ao licenciando a base teórica dos conteúdos da sua futura área de atuação, e vivências de metodologias que possam usar em sala de aula para potencializar o processo de ensino-aprendizagem. Dentre as temáticas metodológicas destacamos a argumentação, visto que por nossa experiência como formadores de professores, temos notado que poucas são as habilidades dos licenciandos em desenvolver ações que possam promover um ambiente argumentativo em sala de aula. Assim, nesta pesquisa nossos objetivos são estudar as contribuições, de uma dinâmica de formação vinculada ao Estágio Curricular Supervisionado no desenvolvimento de uma prática docente reflexiva e a suscitação e compartilhamento de saberes docentes referentes ao uso da argumentação em sala de aula. Pretendemos assim, contribuir com o planejamento e desenvolvimento de ações nos cursos de formação inicial de professores que venham a preparar o licenciando a abordarem estratégias argumentativas em sala de aula. A pesquisa foi desenvolvida com seis licenciandos de um curso de Licenciatura em Ciências Exatas que cursavam a disciplina de Prática do Ensino de Química. Na referida disciplina, os licenciandos tinham que em sua regência desenvolver e implementar aulas de Química para o Ensino Médio num ambiente argumentativo. Os dados foram coletados nas ações desenvolvidas em cinco momentos, sendo que no primeiro estudamos as concepções que os licenciandos tinham sobre argumentação, no segundo foram desenvolvidas atividades relacionadas ao Estágio de Observação, no terceiro, as atividades tinham por objetivo proporcionar aos futuros professores uma base de conhecimento sobre o uso da argumentação em um contexto de ensino-aprendizagem. No quarto momento, os licenciandos desenvolveram e ministraram sua regência e no último tiveram espaços para reflexão da sua prática docente, desde uma perspectiva individual à coletiva. Como fonte de coleta de dados utilizamos observações com anotações em um diário de campo, entrevistas, questionários, registros de áudio e vídeos, projetos e relatórios da regência e materiais postados no blog da disciplina. Como resultados obtivemos que a dinâmica desenvolvida na disciplina possibilitou aos licenciandos vivenciarem um movimento em que os aspectos teóricos e práticos da ação argumentativa estavam em um constante movimento cíclico, em que em muitos casos a prática foi utilizada para dar sentido a teoria e vice-versa. Estes movimentos foram identificados como sendo o de Reflexão sobre o planejamento da ação, Reflexão na ação e Reflexão sobre a ação, e tinham uma relação direta e cíclica entre a teoria relacionada à argumentação e a prática do licenciando, que envolveu desde o planejamento das atividades referentes à argumentação até sua implementação. Tais movimentos possibilitaram uma mobilização e desenvolvimento de Saberes de Argumentação Docente que forneceram ao licenciando uma base para desenvolver e 
analisar a atividade de natureza argumentativa. Diante aos resultados assumimos que o momento de formação inicial pode e deve ser uma oportunidade para os licenciandos desenvolverem habilidades que venham a possibilitar o desenvolvimento de ambientes argumentativos em suas aulas e que experimentem, reflitam e criem um hábito de compartilhamento de experiências com seus pares no que tange a ações argumentativas. Defendemos assim, a incorporação de conteúdos da argumentação nos programas de formação inicial de professores de Ciências, de maneira que os futuros professores possam ter ferramentas e conhecimento para trabalharem a argumentação em sua prática docente.

Palavras-chave: formação inicial de professores, argumentação, saberes 


\section{RESUMEN}

LOURENCO, A. B. Saberes Docentes de Argumentação: Dinâmicas de desenvolvimento na formação inicial de professores de Ciências. 2013. 254 f. Tese (Doutorado) - Instituto de Física, ao Instituto de Química, ao Instituto de Biociências e a Faculdade de Educação da Universidade de São Paulo, São Paulo e Facultad de Formación de Professorado da Universidad Autónoma de Madrid, Madrid, 2013.

La formación inicial de los docentes es un momento clave para la mejora de la educación, pues aporta a los futuros profesores tanto una base teórica de los contenidos de su futura área de actuación como experiencias metodológicas que puedan usar en clase para mejorar el proceso de enseñanza-aprendizaje. Entre las diferentes estrategias didácticas a disposición de los docentes destacamos la argumentación, ya que por nuestra experiencia como formadores de docentes hemos notado que son pocas las habilidades de los estudiantes para desarrollar acciones que puedan promover un ambiente argumentativo en el aula. Esta investigación se plantea como objetivo estudiar las contribuciones de una dinámica de formación vinculada a una asignatura de práctica docente en el desarrollo de una práctica reflexiva, de promoción y de compartir saberes docentes sobre el uso de la argumentación en el aula. Pretendemos así contribuir a la planificación y desarrollo de acciones en las carreras de formación inicial de los docentes, que los preparen para abordar estrategias argumentativas en el aula. La investigación fue desarrollada con seis estudiantes de la carrera de formación de profesores en Ciencias Exactas que asistieron la asignatura de Práctica de la Enseñanza de la Química para la enseñanza secundaria. Los futuros profesores tenían que desarrollar e implementar espacios argumentativos en la asignatura de Química y como parte de su práctica docente. Los datos fueron recogidos en acciones que ocurrieron en cinco momentos. En el primero estudiamos las concepciones que tenían los futuros profesores sobre la argumentación, en el segundo momento se desarrollaron las actividades relacionadas a las estadías de observación, en el tercero las actividades tenían como objetivo proporcionar a los futuros profesores una base de conocimiento sobre el uso de la argumentación en un contexto de enseñanza y aprendizaje. En el cuarto momento los futuros profesores desarrollaron e impartieron sus clases y en el último tuvieron espacios para reflexión de su práctica docente, desde una perspectiva individual y colectiva. Como fuente de recogida de los datos utilizamos observaciones de notas en un diario, entrevistas, cuestionarios, grabaciones de audio y videos, los proyectos y los informes de las prácticas docente de los futuros profesores y los materiales publicados en el blog de la asignatura. Como resultados obtuvimos que la dinámica desarrollada en la asignatura permitió a los estudiantes experimentar un movimiento en el que los aspectos teóricos y prácticos de la acción argumentativa estaban en constante movimiento cíclico, donde en muchos casos se utilizó la práctica para entender la teoría y viceversa. Estos movimientos fueron identificados como de Reflexión sobre la planificación de la acción, de Reflexión en la Acción, o de Reflexión sobre la Acción. Los movimientos tenían una relación directa y cíclica entre la teoría de la argumentación y la práctica de los futuros profesores, las cuales envolvían desde la planificación de actividades relacionadas con la argumentación 
hasta su implementación. Estos movimientos posibilitaron una movilización y un desarrollo de los Saberes de la Argumentación Docente que sirvieron de base para que los futuros profesores desarrollaran y analizaran actividades de naturaleza argumentativa. Teniendo en cuenta los resultados asumimos que el momento de la formación inicial puede y debe ser una oportunidad para que los futuros profesores desarrollen habilidades que les permitan desarrollar entornos argumentativos en sus clases y experimentar, reflexionar y crear un hábito de compartir experiencias con sus pares con respecto a las acciones argumentativas en el aula. Defendemos así la incorporación de contenidos argumentativos en los programas de formación inicial de profesores de Ciencias, de manera que puedan tener las herramientas y conocimientos necesarios para trabajar la argumentación en su práctica docente.

Palabras clave: formación inicial de profesores, argumentación, saberes 


\begin{abstract}
LOURENCO, A. B. Saberes Docentes de Argumentação: Dinâmicas de desenvolvimento na formação inicial de professores de Ciências. 2013. 254 f. Tese (Doutorado) - Instituto de Física, ao Instituto de Química, ao Instituto de Biociências e a Faculdade de Educação da Universidade de São Paulo, São Paulo e Facultad de Formación de Professorado da Universidad Autónoma de Madrid, Madrid, 2013.
\end{abstract}

The initial training of teacher's is a moment of utmost importance, because it should provide the undergraduate the theoretical basis of the content of their future area of expertise, and experiences of methodologies they can use in classroom to enhance the teaching-learning process. Argumentation was highlighted among the methodological issues, since by our experience as teacher's trainer; we have noticed that there are few undergraduate skills in developing actions that promote an argumentative environment in classroom. Thus, in this study our objectives are to study the contributions of a dynamic training linked to the Supervised Internship in developing a reflective teaching practice, resuscitation and knowledge sharing regarding the use of argumentation in the classroom. Therefore we wish to contribute to the actions of planning and development in the courses of initial teacher's training which will prepare the undergraduates to address argumentative strategies in the classroom. The research was conducted with six undergraduates of Bachelor of Mathematical Science who attended the Teaching Practice of Chemistry discipline. In this discipline, the undergraduates had to, in their regency, develop and implement Chemistry classes for high school in an argumentative environment. Data were collected in the developed actions on five occasions, firstly we studied the conceptions that the undergraduates had about argumentation, secondly activities related to practical curricular training were developed, thirdly the activities aimed to provide a basis for future teachers about the use of argumentation in the context of teaching and learning. Fourthly the undergraduates developed and ministered their regency and lastly they had room for reflection of their teaching practice from an individual to a collective perspective. As a source of data collection, we used observations with journaling, interviews, questionnaires, audio and video recordings, projects and regency reports and materials posted on the course blog. As a result, the dynamic developed in the discipline enabled the undergraduates to experience a movement in which theoretical and practical aspects of argumentative action were in a constant cyclical movement, where in many cases the practical was used to accomplish the theory and vice versa. These movements were identified as being of Reflection on action planning, reflection in action and reflection on action, and had a direct and cyclical relationship between theory related to argumentation and the undergraduate practice, which involved from planning activities related to the argument to its implementation. Such movements enabled the mobilization and development of Knowledge for Teaching Argumentation that provided a basis for undergraduate to develop and analyze activity of argumentative nature. As a result we assume that the initial training can and should be an opportunity for undergraduates to develop skills that will enable the development of argumentative environments in their classes and to experience, reflect and create a habit of sharing experiences with their peers in respect to argumentative actions. We conclude as 
such that embedding of content of argumentation in the initial training program of science teachers, so that future teachers may have tools and knowledge to argue in their teaching practice.

Keywords: initial training of teacher's, argumentation, knowledge 


\section{SUMÁRIO}

INTRODUÇãO E JUSTIFICATIVA DA PESQUISA

1. A Formação iniCial de PROFESSORES NO BRASIL: NORMATIVAS LEGAIS E TEÓRICAS ..............................................................32

1.1. A Educação no contexto brasileiro: uma introdução a Educação Básica.

1.2. Diretrizes ao desenvolvimento de cursos de formação de professores no contexto brasileiro 36

1.3. Formação inicial de professores: uma breve revisão da literatura ............ 41

1.4. O papel do estágio na formação de professores ...................................... 51

2. SABERES DOCENTES EM UMA PERSPECTIVA DE TARDIF E FREIRE

2.1. Saberes docentes

2.2. Saberes docentes e a pesquisa na formação de professores de Ciências: um contexto inicial

3. ArgumentaÇão no EnSINO de CiênCIAS

3.1. Uma introdução: A argumentação no Ensino de Ciências

4. OBjetivos e Metodologia

4.1. Objetivos

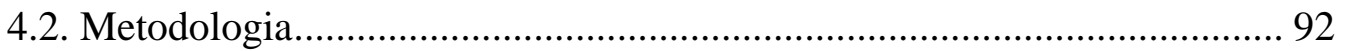

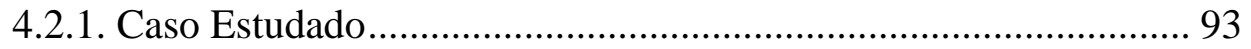

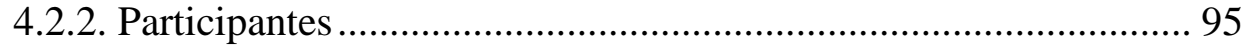

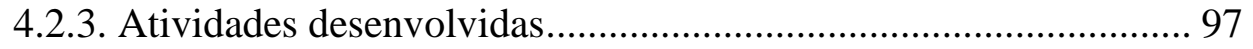

4.2.3.1. Instrumentos de coleta de dados ............................................... 99

4.2.3.1. Primeiro momento: Conhecimento prévio dos licenciandos

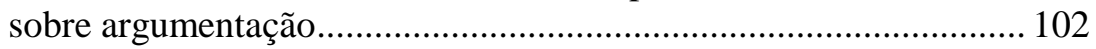

4.2.3.2. Segundo momento: Estágio de Observação ............................... 103

4.2.3.3. Terceiro momento: Atividades sobre argumentação.................. 104

4.2.3.4. Quarto momento: Atividade de regência................................... 108

4.2.3.5. Quinto momento: Reflexão sobre a prática docente................... 110

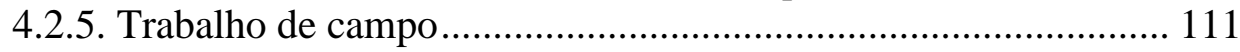

4.2.6. Análise de Conteúdo ............................................................. 112

5. RESULTADOS ......................................................................................... 116

5.1. Construção das categorias de análise .................................................. 116

5.2. Concepções prévias dos licenciandos sobre argumentação ................... 129

5.3. Estágio de Observação ......................................................................... 133

5.3. Atividades sobre argumentação........................................................... 140 
5.4. Atividades de regência

6. DISCUSSÃo

6.1. Concepções dos licenciandos sobre argumentação 195

6.2. Uma trajetória de reflexões sobre a prática docente dos licenciandos

6.3. O desenvolvimento e mobilização de Saberes de Argumentação Docente 220

7. CONSIDERAÇÕES FINAIS

7.1. Síntese dos Resultados 227

7.2. Síntese da Discussão 228

7.3. Limitações da Investigação 230

7.4. Aplicação e contribuições da Investigação 231

7.5. Conclusões 232

7.6. Futuras Investigações 233

REFERENCIAS.................................................................. 235

APÊNDICES .

Apêndice 1. Referências dos trabalhos localizados sobre saberes docentes nas principais revistas brasileiras de Ensino de Ciências

Apêndice 2- referências dos trabalhos localizados sobre argumentação nas principais revistas brasileiras de Ensino de Ciências.

Apêndice 3 - Roteiro para o estágio de observação 250

Apêndice 4- Orientações à elaboração do projeto de regência .252

Apêndice 5- Ficha para anotações das apresentações de compartilhamentos de experiências dos licenciandos. 253

Apêndice 6- Roteiro da entrevista realizada com os licenciandos. 


\section{LISTA DE FIGURAS}

FIgURA 1: ESQUema do MOdELO de TOULMIN ADAPTADO dE SÁ E QUEIROZ (2009). 76

FIGURA 2: ESQUEMA SOBRE OS SABERES DE ARGUMENTAÇÃO DOCENTE UTILIZADOS NA CATEGORIZAÇÃO DOS SABERES DOS LICENCIANDOS 126

FIGURA 3: ESQUEMA QUE REPRESENTA RELAÇÕES ENTRES SABERES DE ARGUMENTAÇÃO DOCENTES E O MODELO DE TOULMIN (2001). 128

FIGURA 4: RESUMO DAS CONCEPÇÕES DOS LICENCIANDOS SOBRE ASPECTOS DA ARGUMENTAÇÃO EM SALA DE AULA EM DOIS MOMENTOS CONFIGURADOS COMO MOMENTO I - CONCEPÇÕES ANTES DE VIVENCIAREM AS ATIVIDADES DA DINÂMICA DE FORMAÇÃO VINCULADA A DISCIPLINA DE PRÁTICA DO ENSINO DE QUÍMICA E MOMENTO II APÓS PARTICIPAREM DA DINÂMICA

FIGURA 5: ESQUEMA DOS MOVIMENTOS DE REFLEXÃO IDENTIFICADOS AO LONGO DAS ATIVIDADES DESENVOLVIDAS PELOS LICENCIANDOS.

FIGURA 6: MAPA CONCEITUAL QUE BUSCA INTEGRAR OS RESULTADOS OBTIDOS AO LONGO DO PROCESSO DE INVESTIGAÇÃO REALIZADO NESTA PESQUISA 


\section{LISTA DE QUADROS}

Quadro 1: Periódicos analisados e quantidade de trabalhos identificados que abordavam a temática de saberes docentes.

Quadro 2: Tipos de saberes elaborados a partir da experiência do estágio. Fonte: Baccon e Arruda (2010).

Quadro 3: Ordem crescente de complexidade dos argumentos de acordo com o modelo de Erduran, Simon e Osborne (2004).

Quadro 4: Periódicos analisados e quantidade de trabalhos identificados. ...

Quadro 5: Perfil escolar e pretensões futuras em relação à carreira docente dos licenciandos sujeitos da pesquisa.

Quadro 6: Relação das atividades desenvolvidas ao longo da investigação.

Quadro 7: Atividades realizadas com e pelos licenciandos e os materiais obtidos.

Quadro 8: Questões aplicadas aos licenciandos para identificar seu conhecimento prévio sobre argumentação.

Quadro 9: Fluxograma com a sequência de atividades realizadas na Oficina de Leitura sobre argumentação.

Quadro 10: Referência dos artigos utilizados na dinâmica de leitura e a relação dos licenciandos que o leram e elaboraram perguntas sobre o texto

Quadro 11: Relação dos licenciandos com os respectivos temas de regência e as séries a quem ministraram a sequência de ensino.

Quadro 12: Categorias dos Saberes de Argumentação Docente relativos ao desenvolvimento de atividades argumentativas em sala de aula 
Quadro 13: Categoria obtida para a concepção dos licenciandos sobre argumentação.

Quadro 14: Categorias obtidas para situações argumentativas que os licenciandos vivenciam como aluno.

Quadro 15: Categorias obtidas para como os licenciandos se sentem a argumentarem em público.

Quadro 16: Justificativa da importância em se trabalhar a argumentação em sala de aula.

Quadro 17: Estratégias e aspectos na visão dos licenciandos que facilitam ou dificultam a argumentação em sala de aula.

Quadro 18: Aspectos mencionados pelos licenciandos e pela docente da disciplina sobre características da argumentação em sala de aula.

Quadro 19: Aspectos mencionados pelos licenciandos e pela docente da disciplina sobre estratégias que podem ser utilizadas na promoção da argumentação em sala de aula.

Quadro 20: Aspectos discutidos pelos licenciandos e pela docente da disciplina sobre as necessidades formativas e atitude do professor no desenvolvimento de atividades que visem à promoção da argumentação em sala de aula.

Quadro 21: Aspectos analisados nas atividades desenvolvidas pelos licenciandos em relação à elaboração, aplicação e reflexão sobre a regência.

Quadro 22: Atividades desenvolvidas por Beatriz para criar um ambiente argumentativo

Quadro 23: Atividades desenvolvidas por João para criar um ambiente da Argumentação durante as aulas de Química do Ensino Médio

Quadro 24: Atividades desenvolvidas por Marta para criar um ambiente argumentativo durante as aulas de Química do Ensino Médio. 
Quadro 25: Atividades desenvolvidas por Pedro para criar um ambiente argumentativo durante as aulas de Química do Ensino Médio.

Quadro 26: Atividades desenvolvidas por Rose para criar um ambiente argumentativo durante as aulas de Química do Ensino Médio.

Quadro 27: Atividades desenvolvidas por Rose para criar um ambiente argumentativo durante as aulas de Química do Ensino Médio. 190 


\section{INTRODUÇÃO E JUSTIFICATIVA DA PESQUISA}

A presente investigação surge a partir de uma preocupação sobre como os cursos de formação inicial de professores podem contribuir para o desenvolvimento de um profissional capaz de proporcionar em aulas de Ciências ambientes propícios a argumentação. A referida preocupação vem da nossa convivência com licenciandos, em especial, de seu último ano de curso, e baseada na formação da pesquisadora, oriunda de um curso de licenciatura, em que percebemos a quase nula habilidade desses profissionais ao se formarem em atuarem com atividades de natureza argumentativa.

Além do despreparo dos licenciandos em atuarem em um campo argumentativo, percebemos que há um grande desconhecimento dos futuros professores sobre ações argumentativas que podem ser realizadas em sala de aula. Há, em nosso ver, uma lacuna entre a formação inicial e o saber do professor para atuar numa perspectiva argumentativa. Percebemos que muitos cursos ainda se pautam unicamente em formar docentes que saibam o conteúdo da sua área de atuação, desconsiderando, em muitas etapas da formação, a necessidade de que o professor desenvolva habilidades que englobem saber ouvir os alunos, fazer com que os mesmos argumentem cientificamente e que transformem a linguagem estudantil cotidiana em científica, como coloca Carvalho (2012).

Tais habilidades requerem dos docentes conhecimentos das metodologias de ensino visando tais resultados, disposição em empregá-las em sala de aula e, 
principalmente, experiências no desenvolvimento das mesmas. Tais experiências não englobam somente $\mathrm{o}$ ato de utilização, mas principalmente sua análise investigativa, em que o professor se coloca como investigador da sua própria prática. Realizando uma análise da afirmativa acima, vemos dois âmbitos de pesquisa que podem ser relacionados diretamente, quais sejam a promoção da argumentação em aula de Ciências e a formação adequada dos professores.

Neste último âmbito, temos que ter claro que esta não se inicia no curso de formação inicial de professores e nem termina nele, pois no caso da profissão docente a convivência direta com a futura prática profissional inicia-se na Educação Infantil e ocorre ao longo de toda a sua carreira escolar. Dentro deste contexto, Penteado (2010) afirma que "Fica, em todos nós que passamos pelos bancos escolares, um professor silenciosamente introjetado, que é preciso desvendar" (PENTEADO, 2010, p. 46).

O foco dos cursos de formação de professores deve ser direcionado aos docentes com o perfil mencionado por Penteado, de modo que suas crenças devam ser refletidas e fundamentadas em novas bases de conhecimento das Ciências da Pedagogia e dos conteúdos específicos para que possam modificar o ensino (MALDANER, 2000). Além disso, os professores precisam estar em constante aperfeiçoamento, o que requer uma contínua aprendizagem e um saber de aprender a aprender.

Em relação à argumentação, é consenso entre os pesquisadores a importância de se desenvolver habilidades argumentativas nos alunos dos diferentes níveis de escolaridade (JIMENEZ-ALEIXANDRE, 2010, DAWSON e VENVILLE, 2009, SIMON, ERDURAN e OSBORNE, 2006 e AUFSCHNAITER et al, 2008, EVAGOROU e OSBORNE, 2013). Destacando alguns motivos têm-se que, pela exposição argumentativa das ideias dos alunos os mesmos constroem explicações dos fenômenos estudados e desenvolvem o pensamento operacional (CARVALHO, 2012). Ao argumentarem, os alunos propõem, apoiam, criticam, avaliam e refinam ideias sobre temas científicos (CROSS et al., 2008).

Ademais, a argumentação colabora com o processo de aprendizagem das Ciências e com debates sociocientíficos e éticos e possibilitam a avaliação e estabelecimento de novas teorias (CAAMAÑO, 2010, EVAGOROU e OSBORNE, 
2013). Ao se criar situações argumentativas em sala de aula é possível trabalhar com explicitações de diferentes pontos de vista, fazer com que os estudantes percebam suas ideias e lacunas e que construam e reconstruam seus pensamentos. Além disso, um Ensino de Ciências com foco na argumentação possibilita que os alunos aprendam sobre a Natureza da Ciência, pois proporciona a oportunidade de envolvêlos na cultura científica.

Outrossim, no mundo em que vivemos, de constantes transformações é necessário que os alunos ao se formarem na Educação Básica, sejam capazes de

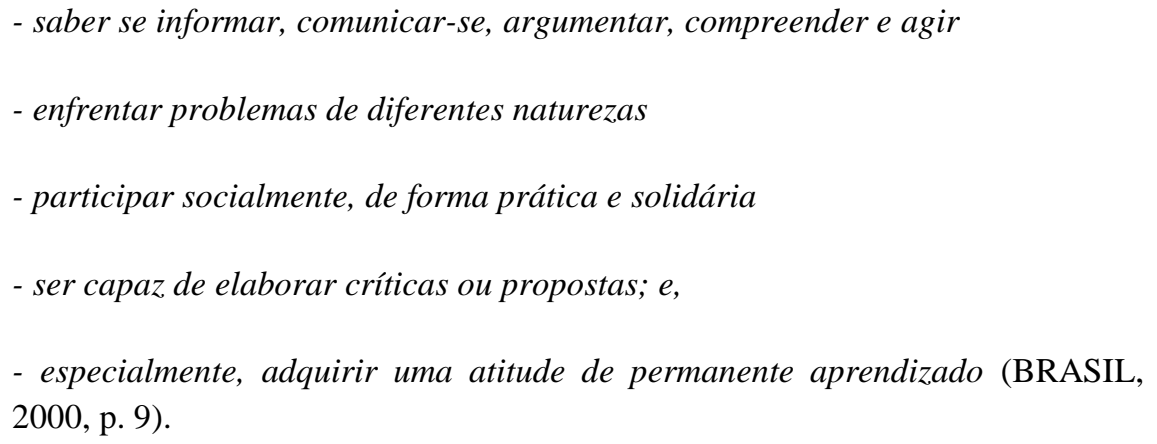

Para isso, os próprios Parâmetros Curriculares Nacionais do Ensino Médio (BRASIL, 2002) apresentam a necessidade de que se utilize em sala de aula métodos de aprendizado compatíveis, que possam gerar condições efetivas para que os alunos possam

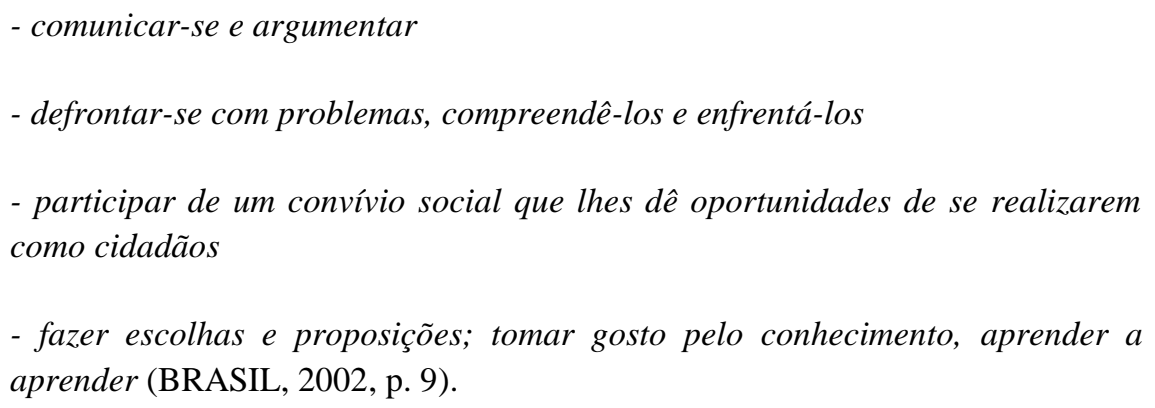

No entanto, para que estes aspectos estejam presentes no cotidiano escolar é fundamental termos docentes capazes de abordá-los. De acordo com Carvalho (2012), isso é possível se o professor possuir habilidades de fazer pequenas e precisas questões, ouvir os alunos, considerar o papel e a importância do erro no processo de aprendizagem e utilizar as ideias destes para a sua síntese entre outros aspectos. As referidas ações podem potencializar a criação de um ambiente 
encorajador em que os alunos adquiram segurança e envolvimento com as práticas científicas, culminando no desenvolvimento da argumentação em aulas de Ciências.

Essas habilidades podem e devem ser trabalhadas nos cursos de formação inicial de professores. Uma vez que esta etapa ocupa um lugar ímpar para uma docência de qualidade, a qual deverá ser pautada, preferencialmente, numa perspectiva investigativa e num trabalho coletivo (BARREIRO e GEBRAN, 2006). É decorrente da necessidade de estudar o desenvolvimento dessas habilidades nesta etapa de formação que realizamos esta investigação. Defendemos a tese de que os licenciandos podem elaborar e/ou aprimorar saberes docentes relativos à argumentação durante a dinâmica de formação ocorrida no processo de Estágio Curricular Supervisionado, os quais podem servir de base para a ampliação e desenvolvimento de outros saberes ao longo da sua carreira profissional docente.

Visando gerar conhecimento sobre esta problemática nos pautaremos em responder duas questões de pesquisa, a saber:

Como se configuram os momentos de reflexão explicitados por futuros professores de Ciências em uma dinâmica de formação vinculada à atividades de Estágio Curricular Supervisionado que priorizam o desenvolvimento de saberes de argumentação?

E, nessa dinâmica de formação,

Quais saberes futuros professores de Ciências desenvolvem no sentido de promover um ensino de caráter argumentativo?

Em vista de termos a argumentação como nosso foco de pesquisa, teceremos algumas considerações sobre a temática. Há na literatura diferentes definições sobre este tema (AUFSCHNAITER, ERDURAN e OSBORNE, 2008, CROSS, TAASOOBSHIRAZI, HENDRICKSC e HICKEYA, 2008, ERDURAN, SIMON e OSBORNE, 2004, JIMÉNEZ-ALEIXANDRE, 2010, JIMÉNEZ-ALEIXANDRE e BUSTAMANTE, 2003, VIEIRA e NASCIMENTO, 2009). No entanto, neste trabalho iremos nos pautar na apresentada por Cross, Taasoobshirazi, Hendricksc e Hickeya (2008) de que a argumentação tem como base um discurso no qual se expõe pontos de vista, baseados ou não em evidências, a respeito de um assunto e pode ser 
direcionada para a argumentação científica em que estudantes propõem, apoiam, criticam, avaliam e refinam ideias sobre temas científicos.

A argumentação apresenta um importante papel no contexto escolar, haja vista que inúmeros trabalhos foram e estão sendo desenvolvidos em que se usam diferentes ferramentas para se criar ambientes propícios à argumentação no Ensino de Ciências. Bargalló e Prat (2010) usaram documentos como textos, vídeos, fotografias etc, com o propósito de formar pessoas interessadas em Ciências e com maior capacidade de argumentar suas ideias. Sá e Queiroz (2009) utilizaram o método de estudos de casos com alunos de um curso de Bacharelado em Química para promover e aperfeiçoar as habilidades argumentativas dos discentes.

Além de trabalhos em que se utilizam diferentes instrumentos para propiciar a argumentação, há aqueles em que os argumentos construídos são objetos de estudos, como apresentado em Capecchi, Carvalho e Silva (2002). Os autores estudaram as interações discursivas que propiciam a argumentação dos alunos em aulas de Física, identificando os componentes de seus argumentos e os padrões discursivos determinados pelas intervenções do professor.

Em Santos, Mortimer e Scott (2007), o foco do estudo foi analisar como a argumentação pode contribuir para discussões de alunos do primeiro ano do ensino médio sobre aspectos sociocientíficos e a necessidade do desenvolvimento de intervenções pedagógicas pelo professor que contribuam para aumentar a capacidade argumentativa dos alunos. Os resultados revelaram que o uso de perguntas que solicitam ao aluno justificar seus pontos de vista pode auxiliar para que percebam a necessidade de melhorar sua argumentação. Os autores indicaram a dificuldade do professor em conduzir o discurso argumentativo em sala de aula, apontando a necessidade de serem desenvolvidas mais pesquisas que os auxiliem a melhorarem a argumentação de seus alunos.

No processo argumentativo em sala de aula o professor tem um papel fundamental, como mostra os resultados apresentados em Chiaro e Leitão (2005). Nesse estudo, os autores analisaram uma aula de história com alunos da quinta série do ensino fundamental. Os alunos foram divididos em dois grupos e tinham que discutir questões a respeito de um texto sobre a escravidão, sendo um grupo mediado 
pela professora e o outro não. Observou-se que ações facilitadoras da argumentação surgiram nos dois grupos, no entanto, as conclusões mais aceitas cientificamente foram feitas pelos alunos em que a professora estava envolvida na atividade.

Ainda em um contexto do papel do professor na promoção do ambiente argumentativo, destaca-se a necessidade destes terem um momento de reflexividade sobre a argumentação, desde uma autoanálise de sua prática a uma análise de suas ações por seus pares (MELO, 2008). Tal indicação apresenta a necessidade de uma prática nos cursos de formação inicial de professores em que os licenciandos avaliem sua atuação e que desenvolvam o hábito da análise ao longo de toda sua carreira docente (BIANCHI, ALVARENGA, e BIANCHI, 2005). Em adição a esta concepção, destacamos que a pesquisa desenvolvida durante a formação inicial, pode fornecer aos licenciandos subsídios ao desenvolvimento de outros projetos dessa natureza quando estiverem atuando como professores (BARREIRO e GEBRAN, 2006).

Diante destes aspectos, estamos de acordo com Archilla (2012) de que existe a necessidade de introduzirmos conteúdos vinculados com a argumentação na formação inicial de professores. Além disso, o referido autor destaca a importância de estudarmos como os futuros professores de ciências adquirem estas habilidades e como podem ser identificadas no seu desenvolvimento profissional. $\mathrm{O}$ autor enfatiza que este é um dos desafios mais relevantes que deve ser tratado no âmbito da Educação em Ciências.

Além disso, os professores não podem ser encarados como simples receptores das pesquisas e inovação didática. Precisam participar de alguma forma no desenvolvimento das pesquisas educacionais, de maneira que se sintam aptos a desenvolvê-las em suas aulas. Além disso, é fundamental que os professores, tanto na formação inicial como na continuada, tenham a pesquisa como princípio formador e como prática, de maneira a construir e reconstruir o conhecimento e a cultura. Superando, desta maneira, o papel do professor como transmissor destes aspectos e desenvolvendo um perfil de professor/pesquisador em uma prática reflexiva na ação e sobre a ação. 
Nesse novo perfil, a sala de aula passa a ser uma situação única, complexa, com incertezas e conflitos de valores, na qual o professor irá refletir, interagir e pesquisar. Neste contexto uma prática compartilhada torna-se fundamental para que o professor possa discutir suas descobertas, comunicar seus avanços e reconstruir suas ações. Além disso, a aquisição e a construção de uma postura reflexiva pressupõem um exercício constante entre a utilização dos conhecimentos de natureza teórica e prática na ação e a elaboração de novos saberes, a partir da ação docente (BARREIRO e GEBRAN, 2006).

Diante do exposto fica evidente não somente a necessidade de se trabalhar com atividades argumentativas em sala de aula, como os professores estarem preparados para o desenvolvimento das mesmas. Nossa experiência, na atuação em disciplinas de estágio de cursos de formação de professores de Ciências, nos revela a pouca habilidade dos licenciandos em relação ao processo argumentativo e até mesmo a falta de conhecimento desta área no processo de ensino-aprendizagem.

Em adendo as considerações acima, estamos de acordo com Archila (2012), de que existe a necessidade de realizar estudos que permitam compreender as formas de argumentação empregada pelos futuros professores de Ciências e há necessidade de formar professores desta área do conhecimento que sejam reflexivos e orientadores de processo educativos inovadores. Assim, buscamos desenvolver um trabalho em que o licenciando se envolvesse em seu processo de aprendizagem e desenvolvimento profissional, assumindo um papel ativo no seu desenvolvimento. Além de participar de um processo de trocas de experiências e materiais de apoio entre os futuros professores, com ênfase a ações de natureza argumentativa.

A organização da nossa pesquisa está dividida da seguinte maneira: na primeira seção apresentamos uma introdução da temática e a justificativa do nosso trabalho, na qual tecemos comentários sobre os caminhos que nos levaram a optar pela temática de estudo e sua importância ao Ensino de Ciências. Apresentamos a seguir aspectos teóricos sobre Educação Escolar num contexto Brasileiro, em que apontamos as diretrizes que a regem e fazemos uma introdução sobre os cursos de formação inicial de professores desde um olhar de leis até os modelos de formação vigentes nas graduações. 
Abarcamos ainda, alguns aspectos do papel do estágio na formação inicial dos professores, visto que as atividades deste trabalho foram vinculadas a uma disciplina voltada ao desenvolvimento do Estágio Curricular Supervisionado de futuros professores de Ciências. Apresentaremos também considerações sobre os saberes docentes desde uma visão dos pesquisadores Tardif (2000) e Freire (1996) e mostraremos trabalhos que buscam analisar e/ou desenvolver esta temática com professores, seja na formação inicial ou continuada. Dentre elas, citaremos pesquisas desenvolvidas por nosso grupo de investigação coordenado pela orientadora desta pesquisa. Finalizamos esta seção com a apresentação de aspectos da argumentação no Ensino de Ciências.

Apresentamos na seção subsequente os objetivos da investigação e a metodologia, na qual explicitaremos o caso estudado identificando o contexto da pesquisa, os critérios de seleção do caso, o perfil dos participantes, as atividades desenvolvidas, o trabalho de campo e a metodologia de análise dos dados. Apresentamos em sequência os resultados e as discussões referentes aos dados. $\mathrm{Na}$ seção de considerações finais discorremos sobre o resumo dos resultados, da discussão, as limitações, contribuições e aplicação da investigação, as conclusões e as futuras pesquisas que podem ser frutos deste trabalho. Finalizamos a tese apresentando as referências bibliográficas e os apêndices. 


\section{A FormaÇÃo INICIAL DE PROFESSORES NO BRASIL: NORMATIVAS LEGAIS E TEÓRICAS}

Os cursos de formação inicial de professores no Brasil são ofertados por estabelecimentos de ensino superior de caráter público ou particular, em que visam à formação de professores para atuarem, dentro da sua especificidade, na Educação Básica e/ou Superior. Em diferentes momentos da graduação os licenciandos devem ter contato com a Lei de Diretrizes e Base da Educação Nacional (LDB), Lei $n^{\circ}$ 9.394, de 20 de Dezembro de 1996 (BRASIL, 1996), a qual é responsável por reger a Educação Brasileira nos seus diferentes segmentos prezando que todos os alunos tenham uma escola de qualidade.

No que concerne à formação de professores, atualmente a mesma é pautada na "Resolução CNE/CP N 1, de 18 de Fevereiro de 2002" (OFICIAL DA UNIÃO, 2002), a qual possui duas complementações, destinada aos estabelecimentos do Estado de São Paulo, sendo a Deliberação CEE 78/2008 (SÃO PAULO, 2008), que fixa as Diretrizes Complementares para a Formação de Docentes para a Educação Básica nos Cursos de Graduação de Pedagogia, Normal Superior e Licenciaturas e a Deliberação CEE no 111/2012 (SÃO PAULO, 2012), que busca complementos às referidas leis e entrou em vigor neste ano de 2013.

Diante da importância destas leis para a formação de professores iremos abordar aspectos das mesmas as quais julgamos relevantes no que tange a formação docente no seu âmbito inicial. Daremos enfoque aos aspectos da lei que são 
referentes ao nível de escolaridade em que os licenciandos que fizeram parte desta pesquisa irão atuar.

\subsection{A Educação no contexto brasileiro: uma introdução a Educação Básica}

Embora a Educação abranja processos formativos que ocorrem na vida familiar, na convivência humana, no trabalho, nas instituições de ensino e pesquisa, nos movimentos sociais, nas organizações da sociedade civil e nas manifestações culturais, a Lei de Diretrizes e Base da Educação Nacional (LDB), se foca na Educação que ocorre em instituições próprias (BRASIL, 1996), e estabelece que a Educação Escolar é formada pela Educação Básica e Superior.

A Educação Básica abrange a Educação Infantil, o Ensino Fundamental e o Ensino Médio e tem como objetivo assegurar a todos educandos uma formação comum indispensável para o exercício da cidadania e meios para progredir no trabalho e em estudos posteriores. Os sujeitos da nossa pesquisa são licenciandos que atuarão nesse nível de educação, mas especificamente no Ensino Fundamental e Médio. Assim, transcrevemos trechos da LDB que apresentam as disposições gerais destes níveis de ensino.

Art. 23. A educação básica poderá organizar-se em séries anuais, períodos semestrais, ciclos, alternância regular de períodos de estudos, grupos nãoseriados, com base na idade, na competência e em outros critérios, ou por forma diversa de organização, sempre que o interesse do processo de aprendizagem assim o recomendar.

\footnotetext{
$\S 1^{o}$ A escola poderá reclassificar os alunos, inclusive quando se tratar de transferências entre estabelecimentos situados no País e no exterior, tendo como base as normas curriculares gerais.

$\S 2^{\circ}$ O calendário escolar deverá adequar-se às peculiaridades locais, inclusive climáticas e econômicas, a critério do respectivo sistema de ensino, sem com isso reduzir o número de horas letivas previsto nesta Lei.
}

Art. 24. A educação básica, nos níveis fundamental e médio, será organizada de acordo com as seguintes regras comuns:

I - a carga horária mínima anual será de oitocentas horas, distribuídas por um mínimo de duzentos dias de efetivo trabalho escolar, excluído o tempo reservado aos exames finais, quando houver; 
II - a classificação em qualquer série ou etapa, exceto a primeira do ensino fundamental, pode ser feita:

a)por promoção, para alunos que cursaram, com aproveitamento, a série ou fase anterior, na própria escola;

b)por transferência, para candidatos procedentes de outras escolas;

c)independentemente de escolarização anterior, mediante avaliação feita pela escola, que defina o grau de desenvolvimento e experiência do candidato e permita sua inscrição na série ou etapa adequada, conforme regulamentação do respectivo sistema de ensino;

III - nos estabelecimentos que adotam a progressão regular por série, o regimento escolar pode admitir formas de progressão parcial, desde que preservada a sequência do currículo, observadas as normas do respectivo sistema de ensino;

IV - poderão organizar-se classes, ou turmas, com alunos de séries distintas, com níveis equivalentes de adiantamento na matéria, para o ensino de línguas estrangeiras, artes, ou outros componentes curriculares;

$V$ - a verificação do rendimento escolar observará os seguintes critérios:

a)avaliação contínua e cumulativa do desempenho do aluno, com prevalência dos aspectos qualitativos sobre os quantitativos e dos resultados ao longo do período sobre os de eventuais provas finais;

b)possibilidade de aceleração de estudos para alunos com atraso escolar;

c)possibilidade de avanço nos cursos e nas séries mediante verificação do aprendizado;

d)aproveitamento de estudos concluídos com êxito;

e)obrigatoriedade de estudos de recuperação, de preferência paralelos ao período letivo, para os casos de baixo rendimento escolar, a serem disciplinados pelas instituições de ensino em seus regimentos;

VI - o controle de frequência fica a cargo da escola, conforme o disposto no seu regimento e nas normas do respectivo sistema de ensino, exigida a frequência mínima de setenta e cinco por cento do total de horas letivas para aprovação;

VII - cabe a cada instituição de ensino expedir históricos escolares, declarações de conclusão de série e diplomas ou certificados de conclusão de cursos, com as especificações cabíveis (BRASIL, 1996, p.20-21).

Quanto ao currículo a ser fornecido na Educação Básica a LDB apresenta que este deve ter uma base nacional comum, a qual deverá ser complementada em cada sistema de ensino e estabelecimento escolar, de acordo com as características regionais e locais da sociedade, da cultura, da economia e da clientela. Em virtude de colaborar com os professores no reconhecimento da complexidade da prática 
educativa e auxiliá-los em sua tarefa de assumir, como profissional, o lugar que lhe cabe pela responsabilidade e importância no processo de formação do povo brasileiro, o Ministério da Educação e do Desporto elaborou e divulgou a todo o país os Parâmetros Curriculares Nacionais (BRASIL, 2000).

Nos Parâmetros são apontadas metas de qualidade para ajudar o docente a desenvolver atividades que possibilitem ao aluno enfrentar o mundo atual como cidadão participativo, reflexivo, autônomo e conhecedor de seus direitos e deveres. São apresentadas nos Parâmetros propostas flexíveis a serem concretizadas nas decisões regionais e locais sobre currículos e sobre programas de transformação da realidade educacional empreendidos pelas autoridades governamentais, pelas escolas e pelos professores (BRASIL, 2000).

No que tange às incumbências dos professores no sistema de ensino optamos por apresentar na íntegra o que diz a LDB. Observamos pela transcrição abaixo que o professor deve fazer parte de todo o processo de ensino tendo uma atuação mais ampla do que somente o espaço físico da sala de aula.

Art. 13. Os docentes incumbir-se-ão de:

I - participar da elaboração da proposta pedagógica do estabelecimento de ensino;

II - elaborar e cumprir plano de trabalho, segundo a proposta pedagógica do estabelecimento de ensino;

III - zelar pela aprendizagem dos alunos;

IV - estabelecer estratégias de recuperação para os alunos de menor rendimento;

$V$ - ministrar os dias letivos e horas-aula estabelecidos, além de participar integralmente dos períodos dedicados ao planejamento, à avaliação e ao desenvolvimento profissional;

VI - colaborar com as atividades de articulação da escola com as famílias e a comunidade (BRASIL, 1996, p.16-17). 


\subsection{Diretrizes ao desenvolvimento de cursos de formação de professores no contexto brasileiro}

Em uma pesquisa ${ }^{2}$ realizada em julho de 2012 no site do Ministério da Educação (MEC, 2012), identificamos que no Brasil as Instituições Públicas ofertavam 3769 cursos de formação de professores (Licenciatura) na modalidade presencial e 308 à distância e as Instituições Particulares disponibilizam 4989 cursos presenciais e 255 na modalidade à distância. A somatória equivale a 9321 cursos de licenciaturas ofertados em todo o território brasileiro.

Todas as licenciaturas têm como base as Diretrizes Curriculares Nacionais para a Formação de Professores da Educação Básica, em nível superior, curso de licenciatura, de graduação plena. Tais diretrizes foram homologadas em 17 de janeiro de 2002 e são apresentadas no documento denominado "Resolução CNE/CP No 1, de 18 de Fevereiro de 2002" (BRASIL, 2002). Apresentaremos trechos das diretrizes que possuem implicações diretas para a formação de professores abordada neste trabalho.

Começaremos com a complementação da referida diretriz no que tange a atuação do licenciando uma vez egresso do curso de graduação. Observamos na transcrição a seguir uma preocupação para que o curso de formação não somente habilite o licenciando em conhecimentos sobre sua área de atuação, mas que forme um profissional envolvido em todo o processo de ensino-aprendizagem e capaz de formar cidadãos diferenciados.

Art. $2^{\circ}$ A organização curricular de cada instituição observará, além do disposto
nos artigos 12 e 13 da Lei 9.394 , de 20 de dezembro de 1996, outras formas de
orientação inerentes à formação para a atividade docente, entre as quais o
preparo para:

I - o ensino visando à aprendizagem do aluno;

II - o acolhimento e o trato da diversidade;

III - o exercício de atividades de enriquecimento cultural;

IV - o aprimoramento em práticas investigativas;

\footnotetext{
${ }^{2}$ A busca foi realizada no endereço eletrônico do Ministério da Educação: http://emec.mec.gov.br/.
} 
$V$ - a elaboração e a execução de projetos de desenvolvimento dos conteúdos curriculares;

VI - o uso de tecnologias da informação e da comunicação e de metodologias, estratégias e materiais de apoio inovadores;

VII- o desenvolvimento de hábitos de colaboração e de trabalho em equipe. (BRASIL, 2002, p.1)

Para que o docente desenvolva e/ou aprimore as habilidades acima mencionadas, é requisito fundamental que na sua formação inicial tenha um espaço para se preparar e se iniciar no ambiente escolar da Educação Básica. Para isso, o curso de formação deve ser concebido seguindo os critérios abaixo descritos.

Art. $3^{\circ}$ A formação de professores que atuarão nas diferentes etapas $e$ modalidades da educação básica observará princípios norteadores desse preparo para o exercício profissional específico, que considerem:

I - a competência como concepção nuclear na orientação do curso;

II - a coerência entre a formação oferecida e a prática esperada do futuro professor, tendo em vista:

a) a simetria invertida, onde o preparo do professor, por ocorrer em lugar similar àquele em que vai atuar, demanda consistência entre o que faz na formação e o que dele se espera;

b) a aprendizagem como processo de construção de conhecimentos, habilidades e valores em interação com a realidade e com os demais indivíduos, no qual são colocadas em uso capacidades pessoais;

c) os conteúdos, como meio e suporte para a constituição das competências;

d) a avaliação como parte integrante do processo de formação, que possibilita o diagnóstico de lacunas e a aferição dos resultados alcançados, consideradas as competências a serem constituídas e a identificação das mudanças de percurso eventualmente necessárias.

III - a pesquisa, com foco no processo de ensino e de aprendizagem, uma vez que ensinar requer, tanto dispor de conhecimentos $e$ mobilizá-los para a ação, como compreender o processo de construção do conhecimento.

Art. $4^{o} \mathrm{Na}$ concepção, no desenvolvimento e na abrangência dos cursos de formação é fundamental que se busque:

I - considerar o conjunto das competências necessárias à atuação profissional; 
II - adotar essas competências como norteadoras, tanto da proposta pedagógica, em especial do currículo e da avaliação, quanto da organização institucional e da gestão da escola de formação. (BRASIL, 2002, p.2)

No que concerne ao Projeto Político Pedagógico dos cursos de Licenciatura o documento (BRASIL, 2002), é enfático na necessidade de serem elaborados com base nas competências objetivas da Educação Básica. Além disso, destacam a necessidade dos referidos cursos ensinarem aos licenciandos mais do que necessitam para ministrar o conteúdo curricular, mas que se formem habilitados a serem docentes que reflitam sobre sua prática, proponham e executem soluções para os problemas da sua atuação.

Art. $5^{\circ}$ O projeto pedagógico de cada curso, considerado o artigo anterior, levará em conta que:

I - a formação deverá garantir a constituição das competências objetivadas na educação básica;

II - o desenvolvimento das competências exige que a formação contemple diferentes âmbitos do conhecimento profissional do professor;

III - a seleção dos conteúdos das áreas de ensino da educação básica deve orientar-se por ir além daquilo que os professores irão ensinar nas diferentes etapas da escolaridade;

IV - os conteúdos a serem ensinados na escolaridade básica devem ser tratados de modo articulado com suas didáticas específicas;

$V$ - a avaliação deve ter como finalidade a orientação do trabalho dos formadores, a autonomia dos futuros professores em relação ao seu processo de aprendizagem e a qualificação dos profissionais com condições de iniciar a carreira.

Parágrafo único. A aprendizagem deverá ser orientada pelo princípio metodológico geral, que pode ser traduzido pela ação-reflexão-ação e que aponta a resolução de situações-problema como uma das estratégias didáticas privilegiadas.

Art. $6^{\circ}$ Na construção do projeto pedagógico dos cursos de formação dos docentes, serão consideradas:

I - as competências referentes ao comprometimento com os valores inspiradores da sociedade democrática;

II - as competências referentes à compreensão do papel social da escola; 
III - as competências referentes ao domínio dos conteúdos a serem socializados, aos seus significados em diferentes contextos e sua articulação interdisciplinar;

IV - as competências referentes ao domínio do conhecimento pedagógico;

$V$ - as competências referentes ao conhecimento de processos de investigação que possibilitem o aperfeiçoamento da prática pedagógica;

VI - as competências referentes ao gerenciamento do próprio desenvolvimento profissional. (BRASIL, 2002, p.3)

Com respeito à iniciação dos licenciandos ao ambiente escolar como futuros docentes as diretrizes abordam que esta não deve ocorrer somente no momento de estágio, mas que deve permear toda a formação do professor. Os cursos devem propiciar aos licenciandos vivências de sala de aula em que possam observar e resolver situações-problema.

Art. 12. Os cursos de formação de professores em nível superior terão a sua duração definida pelo Conselho Pleno, em parecer e resolução específica sobre sua carga horária.

$\S 1^{\circ}$ A prática, na matriz curricular, não poderá ficar reduzida a um espaço isolado, que a restrinja ao estágio, desarticulado do restante do curso.

$\S 2^{\circ}$ A prática deverá estar presente desde o início do curso e permear toda a formação do professor.

$\S 3^{\circ}$ No interior das áreas ou das disciplinas que constituírem os componentes curriculares de formação, e não apenas nas disciplinas pedagógicas, todas terão a sua dimensão prática.

Art. 13. Em tempo e espaço curricular específico, a coordenação da dimensão prática transcenderá o estágio e terá como finalidade promover a articulação das diferentes práticas, numa perspectiva interdisciplinar.

$\S 1^{o}$ A prática será desenvolvida com ênfase nos procedimentos de observação e reflexão, visando à atuação em situações contextualizadas, com o registro dessas observações realizadas e a resolução de situações-problema.

$\S 2^{\circ}$ A presença da prática profissional na formação do professor, que não prescinde da observação e ação direta, poderá ser enriquecida com tecnologias da informação, incluídos o computador e o vídeo, narrativas orais e escritas de professores, produções de alunos, situações simuladoras e estudo de casos.

$\S 3^{\circ} O$ estágio curricular supervisionado, definido por lei, a ser realizado em escola de educação básica, e respeitado o regime de colaboração entre os sistemas de ensino, deve ser desenvolvido a 
partir do início da segunda metade do curso e ser avaliado conjuntamente pela escola formadora e a escola campo de estágio.

Art. 14. Nestas Diretrizes, é enfatizada a flexibilidade necessária, de modo que cada instituição formadora construa projetos inovadores e próprios, integrando os eixos articuladores nelas mencionados (BRASIL, 2002, p.5).

Em complementação as Diretrizes Curriculares Nacionais para a Formação de Professores da Educação Básica, o Conselho Estadual de Educação do Estado de São Paulo, onde esta pesquisa foi desenvolvida, emitiu uma deliberação CEE 78/2008 (São Paulo/2008, p.1), em que "fixou normas complementares à formação dos profissionais docentes em cursos de licenciatura para a Educação Básica, oferecidos pelos estabelecimentos de ensino superior, vinculados ao sistema estadual ressalvada a autonomia universitária".

Buscando uma complementação a referida deliberação o mesmo órgão emitiu no ano de 2012 a Deliberação CEE N 111/2012 (São Paulo/2012), a qual entrou em vigor no primeiro semestre de 2013. Em decorrência dos licenciandos desta pesquisa terem realizado sua graduação anterior à referida deliberação, nos focaremos em destacar aspectos somente da Deliberação CEE 78/2008.

A Deliberação CEE 78/2008 apresenta que o Ensino Fundamental será dividido em 2 ciclos, sendo: $1^{\circ}$ ciclo - anos iniciais do $1^{\circ}$ ao $5^{\circ}$ ano e $2^{o}$ ciclo - anos finais do $6^{\circ}$ ao $9^{\circ}$ ano. Os cursos de graduação voltados para professores do $2^{\circ}$ ciclo e do Ensino Médio deverão dedicar no mínimo, 25\% da sua carga horária total para desenvolver conteúdos curriculares nos licenciandos de maneira a atingir os seguintes objetivos:

I - desenvolvimento de competências básicas em Língua Portuguesa, estatísticas e indicadores educacionais;

II - análise reflexiva dos conteúdos e diretrizes curriculares das disciplinas que é objeto de sua futura atuação docente nos quatro anos finais do Ensino Fundamental e no Ensino Médio;

III - elaboração de práticas pedagógicas adequadas à transmissão dos conteúdos curriculares dos níveis de ensino e desenvolver, nos alunos as competências esperadas, explicitando as formas de transposição didática do conhecimento do professor para aqueles a serem adquiridos pelos alunos." (SÃO PAULO, 2008, p. 4) 
Além disso, na estrutura curricular dos cursos de licenciatura para os anos finais do Ensino Fundamental e no Ensino Médio deverá ser previsto um bloco de apoio às atividades profissionais que contemple: I - estudos de Psicologia da adolescência; II - estudo de processos de avaliação; III - estrutura e problemas do sistema de ensino correspondente ao nível em que irá atuar e IV - integração da disciplina específica com os outros componentes da estrutura curricular.

Como fechamento das ideias concernentes as leis expostas nas seções anteriores, a saber: Lei de Diretrizes e Base da Educação Nacional (BRASIL, 1996), Resolução CNE/CP Nº 1 (OFICIAL DA UNIÃO, 2002), Deliberação CEE 78/2008 (SÃO PAULO, 2008), Deliberação CEE 111/2012 (SÃO PAULO, 2012), observamos que os cursos de formação inicial de professores têm a missão de além de formar um professor que saiba conteúdo programático, também habilite os profissionais capazes de formar cidadãos capazes de serem ativos em uma sociedade de constantes mudanças. Temos neste contexto que a formação inicial assume um papel ímpar para a atuação docente, devendo ser cuidadosamente planejada e desenvolvida.

\subsection{Formação inicial de professores: uma breve revisão da literatura}

Inúmeras são as críticas aos cursos de formação inicial de professores no Brasil. Dentre elas, destacam-se a dicotomia das aulas práticas e teóricas e a falta de uma interação harmoniosa entre os conhecimentos específicos da área e a parte pedagógica (MALDANER, 2000; BROIETTI e BARRETO, 2011). Tais aspectos são intensificados pelo fato de muitos cursos ainda serem resistentes às mudanças e se pautarem, mesmo que de maneira extraoficial, ao modelo " $3+1$ ", em que nos três primeiros anos são trabalhados os conteúdos específicos e no último as disciplinas de natureza pedagógica.

É comum encontrarmos cursos de licenciatura que mantêm resistência em pensar em um ambiente multidisciplinar, o qual possibilitaria habilitações múltiplas, bem como um currículo mais interdisciplinar e integrado (SILVA, 2012; BROIETTI e BARRETO, 2011). A maneira como, em geral, os cursos de formação de professores estão sendo desenvolvidos promove ... 
uma separação da formação profissional específica da formação em conteúdos, cria uma sensação de vazio de saber na mente do professor, pois é diferente saber os conteúdos de Química, por exemplo, em um contexto de Química, de sabê-los, em um contexto de mediação pedagógica dentro do conhecimento químico". (MALDANER, 2000, p. 45)

Tal situação acaba por gerar nos professores e nos futuros professores uma deficiência na sua perspectiva pedagógica, o que interfere no processo de ensino e aprendizagem ocorridos quando assumem a prática docente (MALDANER, 2000). Isso acarreta a necessidade dos cursos de formação de professores aprofundarem as questões pedagógicas, a partir de uma prática em que os licenciandos compreendam a realidade escolar (MELO, 2008). É inegável a importância que estes cursos têm para o progresso e desenvolvimento da sociedade, uma vez que formam profissionais que irão influir em diferentes setores, já que a base cultural do país depende da educação e formação que todos recebem na escola (BIANCHI, ALVARENGA e BIANCHI, 2005).

No caso dos cursos de formação de professores de Ciências, foco deste estudo, estes têm um importante papel na mudança do nível de conhecimento dos alunos da Educação Básica sobre esta área. Atualmente, este conhecimento tem apresentado indicadores negativos como revelam resultados recentes do Programa Internacional de Avaliação de Estudantes (PISA). No entanto, não precisamos dos dados do PISA para sabermos que o Ensino de Ciências no Brasil apresenta problemas, basta frequentarmos as aulas em diferentes escolas e analisarmos o nível de conhecimento dos alunos, o qual em geral, se resume a memorização dos conteúdos.

Para reverter este quadro, o professor de Ciências é partícipe fundamental do processo, pois além de trabalhar os conteúdos de forma significativa precisa atuar como mediador no processo de inclusão científica e tecnológica. Desta forma, os docentes podem contribuir para que os estudantes compreendam as Ciências, transpondo-a quando necessário ao seu cotidiano e motivando-os na curiosidade científica. Para isso, os cursos de licenciatura, entre outros aspectos, devem dar uma preparação suficiente aos licenciandos, para que sejam capazes de superar e responder às representações de mundo presentes na sociedade atual diante das novas 
descobertas científicas e dos avanços tecnológicos (VASCONCELOS e LIMA, 2010).

Além dos aspectos acima mencionados é necessário considerar também que a formação do futuro professor inicia-se muito antes da sua formação "formal". Uma vez que, da Educação Infantil até o Ensino Superior o sujeito desenvolve modelos de professores e concepções alternativas sobre o processo de ensino e aprendizagem, as quais são incorporadas de forma acrítica e sedimentadas ao longo de sua vida escolar. Em geral, interiorizam um modelo em que o professor é o transmissor e conhecedor do saber e o transmite a seus alunos.

Corroborando com estas afirmações Kenski (1991) apresenta um estudo realizado com professores recém-formados, em que estes revelam que ao se verem diante de seus alunos pela primeira vez recuperam a lembrança das metodologias utilizadas por alguns de seus antigos professores e passam a empregá-las e a criar seus próprios modelos. Tais concepções influenciam em muitas vezes de forma negativa no processo de ensino-aprendizagem ocorrido em sala de aula, por isso, é necessário que durante a formação docente o licenciando tenha um espaço para viver uma intervenção reflexiva (PENTEADO, 2010), como ocorre nas atividades do tipo Pesquisa-Ensino.

De acordo com Penteado (2010), este é um processo inquiridor e problematizador da docência, do processo de ensino e do professor introjetado que reside em todos nós, em que visa à superação de problemas pedagógicos constatados. A Pesquisa-Ensino possibilita ...

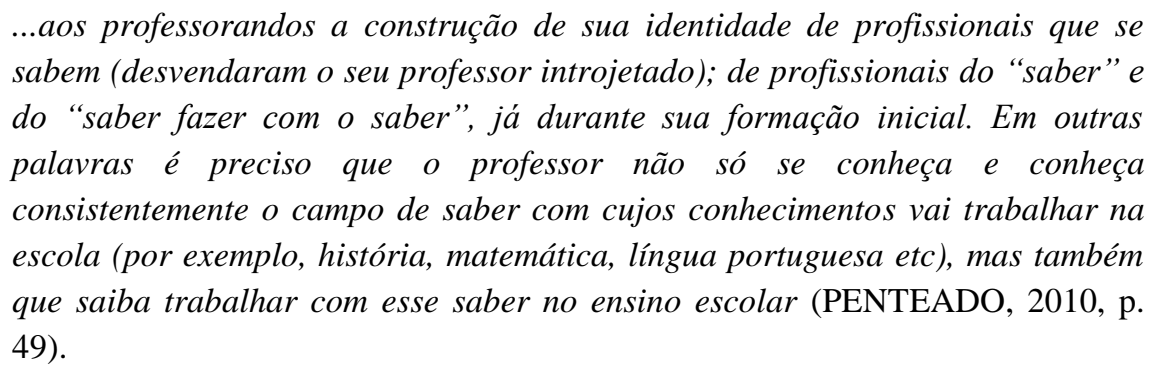
sabem (desvendaram o seu professor introjetado); de profissionais do "saber" $e$ do "saber fazer com o saber", já durante sua formação inicial. Em outras palavras é preciso que o professor não só se conheça e conheça consistentemente o campo de saber com cujos conhecimentos vai trabalhar na escola (por exemplo, história, matemática, língua portuguesa etc), mas também que saiba trabalhar com esse saber no ensino escolar (PENTEADO, 2010, p. 49).

É fundamental que docentes ainda na sua formação inicial tenham contato com atividades numa vertente de Pesquisa-Ensino, para que possam conceber sua prática docente como um momento de desenvolvimento profissional, em que poderão 
desenvolver saberes, os quais se constituem em uma ampla rede tecida a partir de múltiplas perspectivas oriundas de diferentes sujeitos que compõem o ambiente escolar.

Ao considerarmos o Projeto Político Pedagógico dos cursos de licenciatura, percebemos que há dois modelos antagônicos que, em geral, servem como base à sua concepção: o modelo da Racionalidade Técnica, da Racionalidade Prática e de forma ainda inicial o modelo da Racionalidade Crítica. Iremos discorrer nas páginas subsequentes sobre determinados aspectos que caracterizam estes três modelos de formação docente, a começar pelo modelo da Racionalidade Técnica, o qual tem recebido inúmeras críticas, quanto ao seu objetivo e ao papel que atribui ao docente. Este modelo vê a etapa de formação inicial de professores como sendo o momento no qual ocorre uma preparação do licenciando para compreender o funcionamento das regras e técnicas da realidade da sala de aula e desenvolver as competências profissionais exigidas pela sua aplicação eficaz em sua futura atuação docente (JALBUT, 2011).

De acordo com Schön (2000) este modelo tem três componentes do conhecimento profissional: o da disciplina fundamental ou Ciência básica, sobre o qual se apoia ou a partir da qual é desenvolvido, o da Ciência aplicada do qual derivam procedimentos de diagnóstico cotidiano e soluções de problemas e as Habilidades e atitudes, em que são utilizadas o conhecimento básico e aplicado. Para Mizukami (2002), essa visão estabelece que

\section{[...] a ordem de importância vai da Ciência básica à Ciência aplicada e a ordem de aplicação é também uma ordem de dependência: a Ciência aplicada é apoiada no fundamento da Ciência básica. E quanto mais básico e mais geral o conhecimento, mais alto o status de seu produtor. Tudo isso repercute na organização curricular dos cursos de formação profissional, em que a regra é: primeiro, a Ciência básica e aplicada e, só então, as habilidades de aplicação destas aos problemas do mundo real na prática. (MIZUKAMI, 2002, p. 19)}

Na Racionalidade Técnica a prática docente é uma fonte de dados aos investigadores acadêmicos, que detectam os problemas da sala de aula, e em seus laboratórios os estudam e sugerem teorias e técnicas para solucioná-los. Nesta visão cabe ao professor da escola básica o papel de aplicar os conhecimentos da academia aos problemas da sua prática (GARRIDO e CARVALHO, 1999). 
Além disso, não possibilita ao futuro professor colocar em evidência sua criatividade e flexibilidade em adaptar-se às características das situações ocorridas no cotidiano escolar (BROIETTI e BARRETO, 2011). Diante de uma sociedade de constante mudança, ter professores ou outro tipo de profissional, com estas características os tornam debilitados em relação às novas situações conflitantes que vão surgindo diariamente, o que remete a uma lacuna entre o conhecimento profissional e as novas demandas da prática profissional docente (LARRAÍ́N, 2011).

Destaca-se também que, nesse modelo ocorre a incorporação de uma concepção de Ciência Positivista e Empírico-Indutivista, em que se considera a Ciência como detentora de verdades descobertas pelos cientistas. Tal visão acaba por ter implicações diretas nas metodologias em sala de aula, um exemplo, é que as aulas práticas passam a ter um caráter demonstrativo em que se comprova o acerto das teorias ou se chega a elas por meio de generalizações a partir de regularidades observadas. Nesta visão as aulas práticas se reduzem à função de motivar os alunos, para que aceitem melhor os conteúdos e os memorizem mais facilmente.

Tendo as aulas de Química como exemplo, vemos que nessa visão positivista há uma tentativa dos professores em transmitirem o conteúdo seguindo a lógica do conhecimento químico, estruturado pelos especialistas no assunto e não na do aluno que precisa aprender a Química. Tais considerações, realizadas por Maldaner (2000), tiveram como base as aulas de Química, como expresso na citação abaixo, no entanto, elas podem ser extrapoladas para as diferentes áreas das Ciências Exatas.

\footnotetext{
Ao não ser problematizado o conhecimento químico, quando da formação universitária, permanecem as crenças dos professores em uma Ciência positiva, "descoberta" linearmente por pessoas especiais - os cientistas. São essas crenças as responsáveis pelo desenvolvimento de um certo programa e que se repete com incrível regularidade. Elas não permitem ver, criticamente, o programa de ensino e, com isso, procura-se passar ou transmitir uma lógica de conteúdos onde os alunos não encontram nexos, e portanto, não aprendem, achando a matéria de Química muito chata, como eles sempre dizem. (MALDANER, 2000, p. 61-62)
}

De modo convergente, Sannamed e Abeledo (2011), expõem que os cursos de formação que seguem o modelo da Racionalidade Técnica proporcionam aos seus estudantes uma preparação formal que não satisfaz as exigências da ação em sala de aula. Tal desajuste acaba por promover nos licenciandos uma depreciação do seu 
curso que acabam por refugiar-se em rotinas na tentativa de elaborar conhecimentos para sanar os problemas diários.

No modelo da Racionalidade Prática, que busca superar as dificuldades do modelo tecnicista, há espaço nos cursos de formação de professores para os licenciandos fazerem experiências, cometerem e tomarem consciência dos seus erros e refletirem constantemente sobre os problemas e a dinâmica gerada por sua atuação cotidiana (PENTEADO, 2010). Tal prática é recomendada à formação dos professores já que as atividades e as interações ocorridas no cotidiano da sala de aula são marcadas “... por uma atmosfera agitada, imprevisível, permeada por conflitos manifestos e latentes e por constrangimentos culturais e institucionais" (GARRIDO e CARVALHO, 1999, p. 150).

Tal realidade requer que o professor não seja um profissional que somente aplique o conhecimento para resolver problemas técnicos, mas que seja um prático reflexivo, em que organiza sua prática com base em reflexões ocorridas antes, durante e depois da ação (GARRIDO e CARVALHO, 1999). Projetar cursos de formação que trabalhem ativamente com a reflexão do futuro professor, possibilita que este desenvolva habilidades de refletir sobre a sua prática docente, em seus diferentes âmbitos, observando e analisando as reações dos alunos e do seu processo de aprendizagem. Desta maneira, o professor desenvolve atitudes investigativas, em que atua como pesquisador, produtor de saber e do saber fazer docente. De acordo com Garrido e Carvalho (1999), tal situação desloca

\section{[...] o eixo de produção do saber pedagógico da universidade para a escola e para a sala de aula em particular. $O$ saber sobre o ensino não se daria antes do fazer, como estabelece o paradigma da racionalidade técnica. Produz-se no esforço de inovação e de procura de novas soluções para os problemas vivenciados. $E$ o trabalho do pesquisador só poderia se efetivar como fenomenologia da prática, isto é, como "reflexão da reflexão da prática", exercida em conjunto com o professor, parceiro necessário" (GARRIDO e CARVALHO, 1999, p. 150).}

Neste modelo de Racionalidade Prática há três conceitos que integram o desenvolvimento de uma prática na formação de um profissional reflexivo, sendo o Conhecimento na Ação, a Reflexão na Ação e a Reflexão Sobre a Ação (SCHÖN, 2000). O primeiro é um conhecimento técnico ou de solução de problemas que se revelam por meio da atuação do profissional e o qual se tem especial dificuldade em 
torná-lo verbalmente explícito. Está relacionado à ação e ao conhecimento sobre como fazer as coisas e está implícito na ação docente. Quando ocorrem situações em que este tipo de conhecimento não é capaz de resolver, o professor desenvolve uma Reflexão na Ação (FREITAS e VILANI, 2002), em que realiza uma pausa para organizar e refletir sobre a ação que está desenvolvendo.

Na Reflexão na Ação o professor deve considerar as suas e as confusões e incertezas dos seus alunos, deve aprender com seus próprios erros e pensar na atividade da prática ao mesmo tempo em que a realiza, convergindo em um diálogo com a situação e sobre a interação. Jalbut (2011) destaca que durante este processo de reflexão na ação ocorrem momentos combinados, a saber: momento de surpresa do docente com a ação do aluno, momento de reflexão em que o professor pensa sobre o fato e procura compreender a razão de sua surpresa, momento de reformulação do problema suscitado pela situação e o momento em que irá agir testando a nova hipótese.

Para Maldaner (2000), neste tipo de reflexão os profissionais tornam-se pesquisadores no contexto prático em que

[...] conseguem lidar com situações singulares em toda a sua complexidade, com incertezas e instabilidades inerentes a elas, sem recorrer a padrões de procedimentos próprios do modelo da racionalidade técnica” (MALDANER, 2000, p. 125).

Na Reflexão sobre a Ação o professor após a ação e tendo um distanciamento da situação a descreve, analisa e avalia, a fim de compreender e reconstruir em novas bases sua prática. Esta reflexão supõe assim um entendimento do Conhecimento na Ação e da Reflexão na Ação, acarretando na interdependência dos três processos, os quais se complementam constituindo o pensamento prático do professor (MIZUKAMI, 2002 e JALBUT, 2011).

De acordo com Jalbut (2011) usar o conceito de reflexão não significa que o professor deve refletir profissionalmente sobre todas suas ações, pois haverá sempre rotina em sua prática. Desta maneira, há de procurar um equilíbrio entre a reflexão e a rotina, em que irá de forma consciente construir a própria prática de forma reflexiva. Longuini e Nardi (2002) apontam que o fato do professor ser reflexivo, torna-o um pesquisador no contexto prático e "quebra" a concepção de que o ensino 
e a pesquisa educacional sobre sua prática docente são entidades separadas, ideia decorrente do modelo de Racionalidade Técnica.

Assim, os cursos de formação de professores devem propiciar possibilidades para que os licenciados considerem a aula como objeto de estudo, aprendam a problematizá-la e a propor hipóteses para a superação das deficiências detectadas. Desta maneira,

\section{[...] relembrando, continuamente suas representações e sua prática, tornando-se sujeito do processo de construção do "ser professor", e caracterizando-se como um "pesquisador principiante”, como um profissional capaz de produzir conhecimento sobre ensino (GARRIDO e CARVALHO, 1999)}

No modelo da Racionalidade Prática, a prática pedagógica constitui-se como espaço propício a construção da atitude investigativa, possibilitando aos licenciandos o delineamento de caminhos que lhes permitam interrogar e intervir em seu cotidiano pedagógico, como profissionais críticos e conscientes. Desta maneira, rompem com as práticas de reprodução e os cursos assumem uma preocupação com a unidade entre teoria e prática, de maneira a consolidar a interação do saber, o saber fazer e do saber ser (MELO, 2008; BARREIRO e GEBRAN, 2006).

Vimos até o momento dois tipos de racionalidade voltada para a formação de professores: a Técnica e a Prática. Na primeira, os professores apenas utilizam os conhecimentos acadêmicos em sua prática, os quais são desenvolvidos por teóricos e pesquisadores educacionais. Desta maneira, o foco está na aplicação eficiente por parte dos docentes da teoria produzida nas universidades na sua prática escolar, em que seu saber experiencial é desvalorizado (ARAUJO, 2009). Na Racionalidade Prática, busca-se a formação e atuação de profissionais autônomos, investigativos, reflexivos, criativos, aptos a tomarem decisões sobre sua ação pedagógica, em situações instáveis e complexas ocorridas no ambiente escolar e capazes de explicitar suas ações e reflexões.

Neste modelo, a prática do professor é encarada como o ponto de partida e de chegada de sua formação, em que o docente assume um papel central e ativo no processo de investigação e desenvolvimento. Ainda, há de se destacar que na Racionalidade Prática ocorre um equilíbrio entre a dimensão prática e teórica (ARAUJO, 2009; PEREIRA, 2006; GHEDIN, 2001). 
Uma terceira racionalidade pouco difundida e utilizada é a Crítica. Segundo Araújo (2009), a mesma adota uma visão dialética para interpretar a realidade social. Neste contexto, o professor propõe um problema que possibilita a promoção de um diálogo crítico em sala de aula, em que se busca mudanças e transformações em si e nas estruturas sociais vinculadas a educação. O professor compreende as razões de sua ação social orientada por uma dada teoria, de maneira que teoria e prática caminham juntas de forma complementar a um mesmo processo (ARAUJO, 2009). A formação do professor nesta concepção,

[...] valoriza a reflexão como uma prática social, na qual o profissional professor ao socializar suas experiências contribui para si e para o outro na aprendizagem do que é ser professor e o impulsiona a enfrentar os desafios e limites de ser e estar na profissão (ARAUJO, 2009, p. 7).

Neste contexto de Racionalidade Crítica, os professores refletem além dos conteúdos que trabalhados, da sala de aula e da escola e incorporaram como elemento de sua reflexão a sociedade e a maneira como se organiza, assumindo um papel de investigador da sua prática e da realidade social. Neste modelo, a formação docente é concebida em uma perspectiva em que o professor irá trabalhar de forma coletiva e investigar a própria prática no sentido transformador (BATISTA e MORAES, 2009). De acordo com este autor, o referido modelo

[...] compreende o momento vivenciado pelo professor e por seus alunos como oportunidades de questionar os conhecimentos existentes, através de um processo democrático e centrado nos alunos, podendo possibilitar a construção do conhecimento, e, sobretudo, contribuir para elucidar as desigualdades sociais. Portanto, esse é um modelo que destaca uma prática intelectual crítica relacionada com os problemas e experiências cotidianas (BATISTA e MORAES, 2009, p. 1).

De acordo com Zibetti (2007) os cursos de licenciatura têm a necessidade de desenvolver nos futuros professores conhecimentos, habilidades, atitudes e valores que possibilitem aos mesmos construírem seus saberes-fazeres docentes a partir das necessidades e desafios que o ensino como prática social lhes coloca no cotidiano. Além disso, a pesquisa provoca nos licenciandos uma desestruturação de suas certezas, pois enfrentar uma situação concreta, a qual precisa ser refletida não pode ser solucionada na simples reprodução de ideias. Nesse contexto, o licenciando é instigado a procurar respostas para os problemas que estão à sua frente, ou seja, a refletir e a elaborar saberes (BARREIRO e GEBRAN, 2006). 
Sanmamed e Abeledo (2011) afirmam que o ensino é uma atividade prática, portanto, aprender a ensinar implica saber fazer. Tal saber requer um conhecimento da ação, o qual pode ser trabalhado, principalmente no período de Estágio Curricular Supervisionado. Isto porque, este momento da formação possibilita que os futuros professores tenham contato com os diferentes âmbitos e atividades da realidade profissional nas melhores condições possíveis e possibilita adquirirem significação para a maioria das ideias e mensagens que são trabalhadas desde a teoria até seu uso no contexto real de sala de aula. Igualmente, é a oportunidade dos licenciandos se verem, comportarem-se, questionarem-se e aprenderem novas formas de enfrentar os problemas e, fundamentalmente, de sentirem-se um pouco profissionais (GARCÉS e PRIETO, 2009).

A nosso ver, é esperado que o licenciando de hoje não tenha uma formação pautada unicamente no modelo da Racionalidade Técnica, já que não é desejável termos em sala de aula profissionais reprodutores do conhecimento, os quais assumam um papel de executor das orientações. É necessário darmos aos professores uma formação que proporcione conhecimentos, habilidades e atitudes para se assumirem como profissionais reflexivos e investigativos. Profissionais que busquem sempre a renovação de sua ação docente, que considerem sua prática num contexto colaborativo, que estejam sempre atentos à diversidade dos seus alunos e sejam comprometidos com o meio social. Tais características podem ser suscitadas quando se trabalha com modelos de formação como da Racionalidade Prática e Crítica que rompem com o modelo tecnicista.

Consideraremos neste trabalho, principalmente, o modelo de formação da Racionalidade Prática. Iremos nos apropriar de suas orientações no que tange à importância da reflexão docente para a formação e ação em sala de aula. De uma maneira ainda que preliminar, pretendemos incorporar reflexões da Racionalidade Crítica. Procuraremos neste modelo, que os licenciandos busquem na sua formação um aspecto social, com consequências sociais, não apenas uma questão de desenvolvimento individual, mas que percebam a importância da sua ação para os demais envolvidos no processo educativo. Além disso, esperamos que os licenciandos levantem problemas de natureza política concernente a sua ação 
docente, questões que envolvem o conhecimento existente e as condições dos alunos e professores.

Ainda no contexto da Racionalidade Crítica, pretendemos que a formação docente possibilite aos licenciandos trabalharem de forma coletiva, de maneira a incoporarem diálogos críticos em suas práticas e que busquem a promoção de um ambiente de maior igualdade e justiça social. Acreditamos que estes aspectos podem ser suscitados quando envolvemos uma dinâmica com foco na argumentação, já que com ela podemos contribuir para prepararmos de forma igualitária os alunos para uma sociedade de constantes mudanças e que requer a formação de cidadãos críticos.

\subsection{O papel do estágio na formação de professores}

De acordo com Parecer do Conselho Nacional de Educação CNE/CP 28/2001 (BRASIL, CNE/CP 28/2001), o Estágio Curricular Supervisionado (ECS) é uma etapa obrigatória nos cursos de licenciatura. De acordo com o referido documento esta possibilita a capacitação em serviço dos futuros professores, deve ser encarada como uma atividade intrinsecamente articulada com a prática e com as atividades de trabalho acadêmico e desenvolvida dentro de um tempo mais concentrado, mas não necessariamente em dias subsequentes. As atividades ao longo do curso devem seguir as seguintes diretrizes:

Art. $1^{\circ}$ A carga horária dos cursos de Formação de Professores da Educação Básica, em nível superior, em curso de licenciatura, de graduação plena, será efetivada mediante a integralização de, no mínimo, 2800 (duas mil e oitocentas) horas, nas quais a articulação teoria-prática garanta, nos termos dos seus projetos pedagógicos, as seguintes dimensões dos componentes comuns:

I- 400 (quatrocentas) horas de prática como componente curricular, vivenciadas ao longo do curso;

II- 400 (quatrocentas) horas de estágio curricular supervisionado a partir do início da segunda metade do curso;

III- 1800 (mil e oitocentas) horas de aulas para os conteúdos curriculares de natureza científico-cultural;

IV- 200 (duzentas) horas para outras formas de atividades acadêmico científico-culturais (BRASIL, CNE/CP 28/2001, p. 16). 
Em uma posição mais atual, temos as Diretrizes Complementares para a Formação de Docentes para a Educação Básica nos Cursos de Graduação de Pedagogia, Normal Superior e Licenciaturas, e na Deliberação CEE n ${ }^{\circ}$ 111/2012 (SÃO PAULO, 2012), aplicada no Estado de São Paulo, que amplia as referidas resoluções conforme transcrição abaixo. Destacamos que estas novas instruções entrarão em vigor no primeiro semestre de 2013.

$$
\begin{aligned}
& \text { Art. } 10 \text { - O estágio supervisionado obrigatório deverá incluir, no mínimo: } \\
& \text { I- } 200 \text { (duzentas) horas de apoio ao efetivo exercício da docência nos } \\
& \text { anos finais do ensino fundamental e no ensino médio; } \\
& \text { II - } 100 \text { (cem) horas dedicadas às atividades de gestão do ensino } \\
& \text { nelas incluídas, entre outras, as relativas a trabalho pedagógico } \\
& \text { coletivo, conselho de escola, reunião de pais e mestres, reforço e } \\
& \text { recuperaçáo escolar nos anos finais do ensino fundamental e no } \\
& \text { ensino médio. } \\
& \text { III - } 100 \text { (cem) horas de atividades teórico práticas e de } \\
& \text { aprofundamento em áreas específicas (SÃO PAULO, 2012, p) }
\end{aligned}
$$

Uma análise dos requisitos do Parecer do Conselho Nacional de Educação CNE/CP 28/2001 (BRASIL, CNE/CP 28/2001), infere que o estágio tem uma dimensão teórica e prática, subjetiva e concreta e que a inserção do professor em formação na escola não ocorrerá somente nos últimos semestres do curso, mas deverá permear a formação inicial desde o início do processo.

Além disso, o estágio deve estar presente em toda a grade curricular, contemplando tanto as disciplinas de cunho pedagógico como as de conteúdo específico da área de atuação. Desta maneira, será possível ao licenciando colocar em prática situações de ensino que visem transformar o conhecimento científico em escolar. A dimensão da prática da formação não será desenvolvida apenas pelo estágio, já que são destinadas 400 horas de Prática como Componente Curricular, a qual deve ser desenvolvida ao longo do curso (PINTO, 2010; BROIETTI e BARRETO, 2011).

As referidas deliberações enfatizam que o momento de estágio possibilita a construção da identidade no decorrer do exercício da sua profissão. Além disso, possibilita ao licenciando ter contato com a realidade escolar, vivenciando ações em 
que poderão ter uma atuação reflexiva e crítica, criando e mesmo complementando a sua identidade como docente (BARREIRO e GERBRAN, 2006; PINTO et al., 2010).

Nesse contexto de criação e/ou ampliação da identidade profissional, torna-se fundamental que os docentes responsáveis pelas disciplinas de estágio e/ou prática, tenham definido claramente o tipo de professor que desejam formar. É imprescindível também que estes desenvolvam juntamente com os estagiários e os docentes da Educação Básica projetos que possibilitem um aproveitamento máximo do estágio, formando um professor consciente de que a prática docente envolve um comportamento de observação, reflexão crítica e reorganização de suas ações. Nessa concepção o licenciando assume uma postura de “(...) investigador preocupado em aproveitar as atividades comuns de sala de aula e delas extraírem respostas que reorientam sua prática pedagógica com os alunos" (KENSKI, 1991, p. 41).

Além disso, se queremos que os nossos futuros professores tenham uma prática investigativa, devemos proporcionar uma investigação a partir da análise, da reflexão, da crítica e de novas maneiras de se educar. É necessário ver o estágio como um momento que vá além da simples reprodução de modelos, mas que possibilite ao licenciando desenvolver, refletir e mobilizar saberes docentes (CARVALHO, 2012 e BROIETTI e BARRETO, 2011).

Pinto (2010) discorre que é no momento de estágio que os alunos se inserem em realidades escolares e ficam mais próximos dos profissionais do mesmo campo de conhecimento. Tal aproximação, permite a sua integração e identificação com a profissão que escolheu ao ingressar na licenciatura. Esta imersão também contribui significativamente ao desenvolvimento dos saberes dos licenciandos, pois estes terão o contato com seu futuro ambiente de trabalho, enfrentarão situações da prática pedagógica e estabelecerão relações com outros professores.

Olhando agora para a constituição do estágio, temos que, frequentemente, ele é desenvolvido pelas etapas de observação e regência. A nosso ver, o momento de observação deve ser considerado como um processo criativo e fonte de dados à análise da situação real de ensino e aprendizagem ocorrida em sala de aula. Esta etapa configura-se como um espaço rico para a reflexão e formação do futuro professor, pois, como colocam Broetti e Barreto (2011) 
[...] ao fazer suas observações, os estagiários podem ao mesmo tempo em que se deparam com conflitos, propor novas estratégias gerando reflexões que tem por objetivo contribuir na sua formação como um profissional reflexivo, isto é, professores com iniciativa para participar nas discussões curriculares, bem como nas reformas educacionais e que apresentem coerência nos confrontos que encontrarão no ambiente escolar que ás vezes se manifestam de forma caótica" (BROETTI e BARRETO, 2011, p. 183).

Já na etapa da regência, os licenciandos além de terem possibilidades de serem participantes, podem também assumir as funções do professor da Educação Básica, de maneira, que, dentre as várias possibilidades, possam aplicar, refletir e propor mudanças e inovações pedagógicas que tiveram contato na universidade. Nessas ações, a nosso ver, é fundamental que os licenciandos tenham o apoio dos professores tanto da universidade como da Educação Básica, de forma que possam receber contribuições de diferentes esferas de atuação.

Nesse processo, é essencial que o estágio proporcione aos licenciandos oportunidades de refletirem sobre sua prática, de maneira individual e coletiva, o que possibilita que sua experiência torne-se um elemento à aprendizagem colaborativa da docência. No entanto, o Estágio Curricular Supervisionado nem sempre é concebido seguindo os princípios acima descritos, pois muitos professores da universidade o baseiam no modelo da Racionalidade Técnica. Nesta visão, o licenciando aprende a ensinar por meio da observação da prática de ensino bem sucedida de professores da escola básica e pela realização de atividades em que deve aplicar da melhor forma possível, as diretrizes a priori aprendidas, de maneira a reproduzir os modelos de aulas supostamente de sucesso.

Concordamos com Monteiro (2002) de que

[...] não podemos negar que, muitas vezes, em nosso país, o estágio na formação de professores ainda se resume a um processo de "indução profissional na prática quotidiana da escola", com os professores em formação aprendendo por ensaio e erro, a partir de observações feitas sobre as práticas de ensino de variados tipos, sem tempo e espaço para a reflexão e crítica, o que leva à reprodução de "vícios, preconceitos e obstáculos epistemológicos (MONTEIRO, 2002, p. 134).

Se nos basearmos no modelo da Racionalidade Prática e também no da Racionalidade Crítica para orientarmos o estágio dos licenciandos, estes poderão ter 
sua subjetividade, sua história e seus saberes reconhecidos e utilizados como mediadores no processo de construção do conhecimento. Para Monteiro,

[...] a Prática de Ensino, ressignificada, pode se tornar uma oportunidade única e muito rica para a constituição da profissionalidade, com a sensibilidade necessária para a educação das novas gerações" (MONTEIRO, 2002, p. 140).

Tal ideia é corroborada por Maldaner (2000), o qual preconiza que

[...] se defendemos que os professores devem atuar como pesquisadores em sua ação docente, porque diante de situações práticas complexas que exigem a produção de saberes e conhecimentos na ação, a prática da pesquisa deve estar presente, também, na formação inicial. Ou seja, a pesquisa é uma construção histórica e cultural cuja aprendizagem precisa ser mediada de maneira intencional, isto é, na forma de ensino dentro de um currículo de formação (MALDANER, 2000, p. 91).

É preciso assumir o estágio como um momento em que o futuro professor vivencia experiências investigativas, as quais devem ser realizadas com o apoio de professores e colegas, que o auxiliarão a superar as dificuldades e medos suscitados pelas atividades desenvolvidas em sala de aula. Este período deve ser visto também como uma primeira oportunidade de exercício para a reflexão, em que diferentes saberes docentes serão articulados e/ou elaborados.

Ademais, é importante que o professor de prática de ensino trabalhe o fato de que o licenciando no estágio vivencia um momento de ser aluno e professor ao mesmo tempo, o que lhe pode aguçar a sensibilidade para perceber as repercussões das ações educativas desde um olhar de aluno. Assim, é importante aproveitar esta situação e possibilitar aos licenciandos viverem com intensidade esse momento para a realização de reflexões sobre as ações desenvolvidas, na perspectiva do professor reflexivo de Schön (MONTEIRO, 2002).

De forma a concluir as exposições acima, mas não de finalizá-las já que compreendemos que há uma grande rede de significados que envolvem cada órgão, cada ação política e /ou educacional, entre outros aspectos na formação inicial de professores, teceremos alguns comentários sobre o estágio nesta etapa de formação. Observamos claramente uma tentativa dos órgãos competentes em mudar a formação dos cursos de licenciatura numa perspectiva de que o conhecimento específico possui a maior atenção ao longo da formação enquanto o conteúdo didático - pedagógico fica caracterizado em um papel secundário. 
Tal mudança preconiza uma formação em que o momento de estágio assume um caráter de construção significativa da identidade do futuro professor, em que deixa de lado a visão tecnicista da ação docente e assume um papel de investigador da sua própria prática. Nesse momento em que os licenciandos estão assumindo um olhar para a prática docente, é necessário que busquem entender os processos de ensino-aprendizagem ocorridos em sala de aula.

Ademais, torna-se fundamental que nos diferentes momentos do estágio, observação da sala de aula e regência, os futuros professores façam movimentos de relacionarem a prática com a teoria. Tal relação entraria em um movimento de que sua prática ou do professor parceiro possa ser estudada desde um olhar da teoria e de sua prática e que possa novamente voltar-se à teoria, elaborando novas teorias pessoais. Entendemos que nesse processo de mudar, cada um assume um papel único o qual forma um todo construtivo na formação do licenciando.

É nesse contexto de Estágio Curricular Supervisionado, que desenvolvemos nossa pesquisa, em que visamos, entre outros aspectos, que este momento de formação ocorra de maneira que os licenciandos possam desenvolver, refletir, e mobilizar saberes docentes num contexto de investigação de sua própria prática docente. 


\section{SABERES DOCENTES EM UMA PERSPECTIVA DE TARDIF E FREIRE}

Entendemos que a ação docente como concebida atualmente é constituída de um conjunto amplo de atividades que contribuem com o desenvolvimento e mobilização de saberes que vão fornecer uma base para a prática docente. Diante da importância desses elementos no processo de formação de professores, buscamos neste trabalho estudar os saberes docentes que estão vinculados com a promoção de atividades argumentativas em sala de aula. Assim, teceremos considerações sobre estes aspectos nesta seção.

\subsection{Saberes docentes}

Buscando a gênese dos saberes, procuramos resposta à pergunta: $\mathrm{O}$ que é um saber? Usamos duas fontes de conhecimento para responder a este questionamento: o dicionário Michaelis da Língua Portuguesa ${ }^{3}$, no qual tivemos uma descrição geral e uma apresentação da amplitude de possibilidades do que é saber, e o trabalho de Tardif (2010), o qual vem se dedicando ao estudo de saberes docentes.

De acordo com o dicionário Michaelis da Língua Portuguesa, saber é:

1) Estar informado de, estar a par, ter conhecimento de; conhecer: 2) Compreender ou perceber um fato, uma verdade, 3) Ser capaz de distinguir ou de dizer, 4) Ser versado em, 5) Estar habilitado para; ser capaz de; ter os

\footnotetext{
${ }^{3}$ Disponível em: http://michaelis.uol.com.br/
} 
conhecimentos especiais ou técnicos de, 6) Possuir amplos e enciclopédicos conhecimentos, 7) Ter conhecimento prático de alguma coisa ou possuir habilidade nela, 8) Ter de cor, 9) Compreender, poder explicar, 10) Pressupor, prever, 11) Ter a certeza ou a convicção de, 12) Estar acostumado a; estar capacitado para, 13) Ter possibilidade, talento ou mérito para, 14) Conseguir, 15) Procurar informar-se de.

Tal definição nos leva a um entendimento de que saber envolve uma variedade de possibilidades, mas que tem na sua essência o conhecimento por parte do sujeito de uma determinada ação. Focando-nos no contexto escolar, em uma visão docente, fazemos uma interpretação que o saber estaria diretamente atrelado ao conhecimento relacionado às atitudes, aos conteúdos, às habilidades e às ações da prática docente.

Concepções convergentes são encontradas na definição de saber proposta por Tardif (2010), em que saberes são:

[...] os pensamentos, as ideias, os juízos, os discursos, os argumentos que obedeçam a certas exigências de racionalidade. Eu falo e ajo racionalmente quando sou capaz de justificar, por meio de razões, de declarações, de procedimentos, etc., o meu discurso ou a minha ação diante de um outro ator que me questiona sobre a pertinência, o valor deles, etc. Essa "capacidade" ou essa "competência" é verificada na argumentação, isto é, num discurso em que proponho razões para justificar meus atos. Essas razões são discutíveis, criticáveis e revisáveis. (TARDIF, 2010, p. 199)

Reiterando e ampliando a referida definição de saber apresentamos o que preconiza Nunes (2001) de que saber é o resultado de uma produção social, sujeito a revisões e reavaliações, tem sua origem na interação entre os sujeitos, de natureza linguística e inserida num contexto, e que tem valor conforme possibilita manter aberto o processo de questionamento. Apresentamos também as considerações de Tardif (2010) de que a elaboração do saber implica em um processo de aprendizagem e de formação e quanto mais desenvolvido, formalizado e sistematizado é um saber, mais longo e complexo se torna este processo.

Além disso, o mesmo autor (TARDIF, 2000) em outra produção, apresenta que os saberes docentes são temporais, já que são elaborados, ampliados e/ou modificados ao longo do tempo. Apresenta como base a esta afirmação o fato de que grande parte do que os professores sabem sobre o ensino, sobre seu papel docente e sobre como ensinar é oriundo de sua própria história de vida, e, sobretudo de sua 
história de vida escolar, já que antes mesmo de começarem a atuar como docente, estão inseridos em seu contexto de trabalho em um papel de aluno. Para Tardif (2000), a referida imersão produz uma bagagem de conhecimentos, de crenças, de representações e de certezas sobre a prática docente, as quais permanecem estáveis/resistentes ao longo do tempo.

Outro aspecto que leva a considerar os saberes com uma natureza temporal é o fato de que os professores nos primeiros anos de sua prática profissional passam por uma fase de exploração. Tal fase é caraterizada por uma aprendizagem intensa do ofício, a qual está vinculada a uma sobrevivência profissional. Neste processo, o professor deve dar provas de sua capacidade, gerando uma edificação de saberes atrelados às experiências, os quais se constituem em certezas profissionais, em truques do ofício, em rotinas, em modelos de gestão da classe e de transmissão da matéria. Ademais, os saberes docentes são considerados temporais por serem desenvolvidos no âmbito de uma carreira, isto é, de um processo de vida profissional de longa duração (TARDIF, 2000).

Para Tardif (2010), a questão do saber não pode ser tratada como uma categoria autônoma e separada das outras realidades sociais, organizacionais e humanas nas quais os professores se encontram imersos. O saber dos professores está relacionado com sua identidade, sua experiência de vida, com sua história profissional, com suas relações com os alunos em sala de aula e com outros sujeitos pertencentes ao universo escolar. O saber dos professores é sempre ligado a uma situação de trabalho com outros, sejam alunos, colegas, pais e supervisores. É um saber ancorado numa tarefa complexa que é ensinar, situado num espaço de trabalho e enraizado numa instituição e sociedade.

Tardif (2010) apresenta motivos que subsidiam sua ideia de que o saber dos professores tem um cunho social. $\mathrm{O}$ autor considera que os saberes docentes são compartilhados por um grupo de agentes, no caso os professores, que possuem uma formação comum, trabalham numa mesma organização e estão sujeitos a condicionamentos e recursos comparáveis, como programas e matérias a serem ensinadas, entre outros elementos. Depois, porque sua posse e utilização estão 
ancoradas por todo um sistema (universidade, administração escolar, Ministério da Educação, etc) que garante a legitimidade e orienta sua definição e utilização.

O próprio objeto de trabalho do professor é social, pois trabalha no sentido de transformar, educar e instruir os alunos. O saber não é um conteúdo fechado em si mesmo, ele se manifesta por meio de relações complexas entre o professor e seus alunos, e principalmente com o coletivo representado pela turma de alunos. O saber é social, pois os saberes a serem ensinados pelos professores e a maneira de ensiná-los evoluem com o tempo e com as mudanças da sociedade (TARDIF, 2010).

Podemos citar o atual uso do computador na sala de aula como ferramenta de ensino. Há uns vinte anos, os professores não precisavam ter noções sobre computadores, porém esta ferramenta ganhou tamanha repercussão e se tornou tão fundamental a sociedade que grande parte dos professores sentem necessidade de incorporá-la em suas aulas. Para isto necessitaram desenvolver e/ou aprimorar os saberes do uso do computador no seu processo de ensino.

Além disso, de acordo com Tardif (2010), o fato do saber dos professores fazer parte de um processo em construção ao longo de uma carreira profissional, na qual se aprende progressivamente a dominar seu ambiente de trabalho, ao mesmo tempo em que se insere nele e o interioriza por meio de regras de ação que se tornam parte integrante de sua "consciência prática", o faz ter um caráter social.

Ampliando as considerações sobre saberes docentes, temos também os trabalhos de Gauthier (1998), Lee Shulman (1987) e Freire (1996), os quais apresentam características dos saberes e pelos quais podemos observar diferenças e similaridades entre os autores. Tardif (2010) categorizou os saberes docentes em: saberes da formação profissional, saberes disciplinares, saberes curriculares e saberes experienciais. Os saberes da formação profissional são adquiridos tanto durante a formação inicial como contínua dos professores e estão relacionados às Ciências Humanas e da Educação. Esse saber orienta os docentes a planejarem e executarem as atividades educativas em sala de aula, a optarem por metodologias mais adequadas para as atividades dos alunos, a construírem instrumentos de avaliação e a darem suporte pedagógico a outras ações educativas na escola. 
Os saberes disciplinares correspondem aos diversos campos do conhecimento, sob a forma de disciplinas relativas às ciências de referência que são ministradas nos departamentos universitários, independente das faculdades de educação e dos cursos de formação de professores. Os saberes curriculares são definidos pelas instituições escolares e apresentam os saberes sociais por ela definidos e selecionados como modelos da cultura erudita e de formação dessa cultura.

Os saberes experienciais são aqueles elaborados pelo professor no exercício de sua atividade educativa, na qual utiliza vários conhecimentos e formas de saberfazer, os quais são mobilizados e utilizados em função dos diferentes contextos variáveis e contingentes da prática profissional. Possuem um caráter aberto, pois relacionam experiências novas, conhecimentos adquiridos dos professores ao longo de sua trajetória e um saber-fazer que se remodela em função das necessidades do trabalho.

O referido saber é único a cada professor, pois está ligado não somente à experiência profissional do docente, mas também a sua história de vida, sendo formado por todos os demais. Tardif (2010) destaca que o saber experiencial é um saber prático e que sua utilização depende de adequação às funções, problemas e situações específicas do trabalho. É interativo na medida em que é mobilizado e modelado no âmbito de interações entre o professor e outros atores do sistema educativo.

Outro investigador que apresentou os saberes indispensáveis à prática educativa foi Paulo Freire (1996). Para o autor, é necessário que o professor ainda enquanto licenciando se assuma como sujeito da produção do saber e considere que ensinar não é transferir conhecimento, mas sim criar possibilidades a sua construção e produção. Nesta concepção, os estudantes vão se transformando em reais sujeitos da construção e reconstrução do saber ensinado, juntamente com o professor. Assim, a este é requerido também que respeite os saberes com que os estudantes, sobretudo os das classes populares chegam à escola e, principalmente, discutam com estes a razão dos saberes em relação com o ensino dos conteúdos. 
Deste modo cabe ao professor respeitar a autonomia e a identidade do educando, o que exige do mesmo uma prática coerente com este saber. O bom senso do professor servirá como base para este respeito à autonomia, à dignidade e à identidade do estudante. O professor deve estar sempre atento aos seus gestos, pois, pode com uma simples atitude valer como força formadora ao estudante ou desmotivá-los. Freire (1996) relata a importância que a atitude de um professor teve na sua vida, o qual o mesmo sem falar uma palavra, conseguiu despertar no autor uma confiança em si mesmo, conforme relatado a seguir

\begin{abstract}
O professor trouxera de casa os nossos trabalhos escolares e, chamando-nos um a um, devolvia-os com o seu ajuizamento. Em certo momento me chama e, olhando ou re-olhando o meu texto, sem dizer palavra, balança a cabeça numa demonstração de respeito e de consideração. O gesto do professor valeu mais que a nota dez que atribuiu à minha redação. $O$ gesto do professor me trazia confiança ainda obviamente desconfiada de que era possível trabalhar e produzir. De que era possível confiar em mim, mas que seria tão errado confiar além dos limites quanto errado estava sendo não confiar (FREIRE, 1996, p. 43).
\end{abstract}

Ainda para Freire (1996) é requerido ao professor que pense certo e aja como tal, o que implica que

[...] a tarefa coerente do educador que pensa certo é, exercendo como ser humano a irrecusável prática de inteligir, desafiar o educando com quem se comunica e a quem comunica, produzir sua compreensão do que vem sendo comunicado. (FREIRE, 1996, p. 38)

Uma prática docente nesta perspectiva crítica de pensar certo envolve o movimento dinâmico e dialético, entre o fazer e o pensar sobre o fazer. Tal situação requer que o aprendiz de educador, ainda mesmo na sua formação inicial, assuma que o ato de pensar certo é produzido por ele em comunhão com o professor formador, em uma reflexão crítica sobre a prática.

Outro saber, destacado por Freire (1996), é o que diz respeito à natureza da prática educativa, em que o professor precisa conhecer as diferentes dimensões que a caracterizam, de maneira que se sinta mais seguro no seu desempenho como docente. É necessário que o mesmo, juntamente com seus alunos, assuma uma postura dialógica, aberta, curiosa, indagadora e não apassivada, enquanto fala ou ouve. É de destaque também a necessidade do professor saber escutar. Para Freire (1996), isso possibilita um ensino democrático, pois, 
[...] se na verdade, o sonho que nos anima é democrático e solidário, não é falando aos outros, de cima para baixo, sobretudo, como se fôssemos os portadores da verdade a ser transmitida aos demais, que aprendemos a escutar, mas é escutando que aprendemos a falar com eles. (FREIRE, 1996, p. 113)

Consideramos que há uma convergência de ideias entre os dois autores no que se refere aos saberes docentes. Para Tardif (2000 e 2010) e Freire (1996) o contexto social, organizacional educativo e outros aspectos humanos influenciam de maneira ímpar na elaboração de saberes docentes. Consideram o movimento temporal dos referidos saberes os quais se dão início ainda mesmo quando os professores apresentam-se em sua vida escolar, já que passaram anos no ambiente em que agora assume uma conotação profissional. O saber é de natureza idiossincrática, porém formado por uma relação direta com outros agentes sejam no contexto escolar ou fora dele. Destacamos também que os saberes, para os dois autores (TARDIF, 2000 e 2010; FREIRE, 1996), são constantemente desenvolvidos e transformados ao longo de sua trajetória de vida.

Buscamos com estes referenciais analisar nossos dados, de maneira a compreender as origens dos saberes com sua referida categorização no que se refere ao saber da argumentação em sala de aula. Além disso, pretendemos entender as ações dos licenciandos enquanto assumem o papel de professores que buscam possibilitar aos seus alunos um ambiente numa perspectiva argumentativa.

\subsection{Saberes docentes e a pesquisa na formação de professores de Ciências: um contexto inicial}

O estudo sistemático sobre os saberes docentes teve seu início no final dos anos 80, como um movimento reformista para determinar uma base de conhecimento dos professores que possibilitasse contribuir para a melhoria da formação desses profissionais (ALMEIDA e BIAJONE, 2007). Desde então, investigações têm sido elaboradas para entendê-los e até mesmo para criar ambientes favoráveis a sua elaboração.

Teceremos, inicialmente nesta seção, comentários sobre investigações do nosso grupo de pesquisa, sob a coordenação da professora Maria Lucia Vital dos Santos Abib. As produções buscam ampliar a literatura em relação aos saberes 
docentes e foram desenvolvidas em três frentes, a saber: a) estudo dos formadores de professores em diferentes contextos; b) professores em exercício e c) formação inicial de professores. Os trabalhos nos deram um embasamento, para um primeiro entender de como ações desenvolvidas em contextos de formação de professores podem colaborar no desenvolvimento e/ou aprimoramento docente e como se caracterizam determinadas dinâmicas de estágio em detrimento de outras.

No que tange ao estudo dos formadores de professores temos a produção de Rodrigues (2006), a qual trabalhou com formador de professores em exercício o denominado Assistente Técnico Pedagógico (ATP). Azevedo (2009) desenvolveu sua pesquisa com os formadores no contexto da formação inicial de professores, num ambiente que envolvia os docentes da universidade responsáveis por disciplinas vinculadas ao Estágio Curricular Supervisionado.

Rodrigues (2006) investigou um projeto de melhoria do ensino de Ciências para as séries iniciais, focado em atividades investigativas no contexto da Física, em que nove ATPs participaram e levaram o projeto a professores em exercício. Neste contexto de pesquisa colaborativa, que compreendeu a reflexão sobre a ação como eixo de desenvolvimento e o qual trouxe contribuições diretas para as intervenções e ações destes profissionais, foram identificados e promovidos processos de desenvolvimentos dos ATPs. Com um olhar na questão relacionada aos saberes desenvolvidos pelos ATPs, destacamos que a participação dos envolvidos no projeto colaborou mais especificamente ao desenvolvimento de saberes vinculados ao trabalho colaborativo.

Azevedo (2009) estudou os saberes docentes relativo aos processos de orientação de estágio, que se apresentam como essenciais aos formadores de professores. Para isso buscou identificar os saberes de orientação que esses profissionais mobilizam ao orientar os estagiários. Obteve que estes estão divididos em 
A autora apresenta que a reflexão dos formadores junto aos seus licenciandos e seus pares possibilitou a mobilização dos saberes concernentes aos aspectos dialógico e afetivo, de autoformação e auto-organização. Aponta que os saberes voltados à ação colaborativa, os técnicos-científicos e pedagógicos e os relativos aos processos teórico-práticos de aprendizagem da docência precisam de uma maior mobilização, desde um contexto da universidade como também nas parcerias interinstitucionais. Azevedo (2009) aponta a necessidade de se instituir políticas que aproximem os formadores de professores da escola básica para o desenvolvimento do estágio, de que haja uma busca de se instituir nos cursos de formação de professores ações condizentes com o modelo da racionalidade emancipatória e crítica.

Quanto aos trabalhos relacionados ao estudo de saberes de professores em atividade, temos a dissertação de Galindo (2007) e Azevedo (2008). Galindo (2007) em seu trabalho buscou compreender as contribuições que um projeto desenvolvido entre universidade e escola trouxe a instituição e, em especial, aos professores em exercício. Focando no que tange aos saberes docentes, o estudo levanta que os professores explicitaram saberes de duas naturezas sendo os saberes pedagógicos gerais e os pedagógicos de conteúdo, porém não observaram saberes conceituais provenientes da implementação do projeto e que os saberes explicitados foram fundamentais para o desenvolvimento de forma efetiva do projeto.

Azevedo (2008) focou sua investigação no estudo sobre o aprimoramento da docência em ensino de Ciências em um contexto de escolarização das séries iniciais do Ensino Fundamental, em que os professores trabalharam com atividades investigativas na busca de soluções a problemas por eles próprios eleitos. É nesse processo formativo que a autora estudou a contribuição do mesmo para a elaboração de saberes docentes dos professores em atividade.

Ficou evidenciado que a pesquisa-ação realizada pelos professores foi fundamental para o desenvolvimento de diferentes saberes concernentes à aprendizagem, como: a auto-organização, a predisposição ao estudo e a pesquisa, a maneira de ensinar Ciências por meio de atividades investigativas e de articular esse ensino com o processo de alfabetização na língua materna, a construção de práticas colaborativas na escola, entre outros. Para a autora, os saberes identificados são 
coerentes com a opção metodológica dos professores de ensinar Ciências numa perspectiva de investigação, Além disso, revelam a relação do docente com a construção da sua concepção de ensino da sua prática educativa, já que

[...] cada saber declarado tem uma estreita relação com a ação, com o trabalho
em desenvolvimento, sendo decorrentes de reflexões realizadas com e sobre
essas ações. Revelam, também, a concepção em que o professor é visto como
sujeito de suas ações, com capacidade para enfrentar os seus problemas de
ensino, precisar seus motivos e, em “atividade”, buscar as possiveis soluções
para eles. Como sujeito desse processo, mostrou ser capaz de transformar os
seus problemas de ensino nos motivos essenciais de sua aprendizagem.
(AZEVEDO, 2008, p. 179)

Destaca-se ainda, que a natureza do modelo de formação numa perspectiva de pesquisa-ação preza que os docentes assumam uma postura de aprendizes de sua docência, em uma busca constante da melhoria de sua prática. O desenvolvimento do referido modelo nesta investigação também fez grandes contribuições à elaboração de saberes da pesquisadora que assumiu nesta pesquisa o papel de formadora.

Em nossa frente de trabalho que aborda os saberes de professores em processo de formação inicial, temos os trabalhos de Jordão (2005) e Moraes (2010). Jordão (2005) trabalhou com licenciandos de um curso de Biologia, em que analisou as contribuições de uma tutoria e pesquisa-ação no estágio supervisionado para a elaboração de saberes profissionais dos futuros professores. A autora obteve que os saberes que mais foram elaborados e sofreram transformações estavam atrelados ao contexto de sala de aula, a saber: conceituais e pedagógicos do conteúdo atrelados ao ensino da Biologia e práticos e pedagógicos gerais referentes à aprendizagem, ao ensino e às ações pedagógicas do professor, à avaliação, à gestão de classe e aos alunos.

Já os saberes curriculares e os sobre os fins educacionais, que envolve o papel social da escola e do professor de Biologia, não foram muito favorecidos pela metodologia utilizada com os licenciandos. A autora considera que a elaboração e transformação de saberes trouxeram benefícios ao desenvolvimento pessoal e profissional dos licenciandos. Tais contribuições estão intimamente relacionadas às características do processo pesquisa-ação, em que se preza pelo trabalho coletivo, pelo planejamento, pela implementação, análise e replanejamento da ação docente, características que pretendemos obter na nossa pesquisa. 
De caráter fundamental para os referidos benefícios estão os ciclos reflexivos que os licenciandos participaram. De acordo com Jordão (2005) os relatos dos futuros professores mostram que

[...] esse envolvimento lhes proporcionou o sentimento de compromisso com a busca de soluções para seus próprios problemas e a percepção da importância da reflexão constante da atividade docente (JORDÃO, 2005, p. 310).

Ainda destaca o papel fundamental da tutora para a colaboração no desenvolvimento de saberes profissionais. Suas ações versavam em incentivar os licenciandos a refletirem sobre suas dificuldades e conflitos, promovia discussões sobre temas relacionados à prática e apresentava os possíveis problemas nas propostas dos licenciandos.

Além disso, explicitava exemplos de sua prática pedagógica, os quais eram algumas vezes incorporados como modelos aos licenciandos, conduzia as reflexões dos estagiários sobre as ações implementadas, promovia um ambiente de dúvidas e questionamentos das ações dos estagiários e posicionava-se, explicitando saberes e sugerindo ações não elencadas pelos licenciandos. Tais ações foram explicitadas pelos futuros professores como sendo um dos principais elementos mobilizadores de sua aprendizagem. Além disso, o ambiente harmonioso entre a tutora e os estagiários configurou-se como elemento facilitador da transformação e elaboração dos saberes docentes dos licenciandos.

Moraes (2010) estudou de que maneira os processos ocorridos em uma disciplina de Estágio de um curso de Ciências Biológicas, num ambiente de supervisão planejado em uma perspectiva Ecológica de formação, são capazes de confrontar as crenças dos futuros professores sobre a prática docente e contribuir para a elaboração e saberes profissionais dos licenciandos. Contextualizamos que a pesquisadora considera que uma supervisão numa perspectiva Ecológica de Formação visa fundamentalmente criar redes relacionais, em que os indivíduos por meios das interações ocorridas e das reflexões que estas suscitam possam desenvolver-se profissionalmente e socialmente.

Faremos um recorte da pesquisa e nos ateremos a reportar os resultados que concernem aos saberes docentes, os quais são de interesse de nosso estudo. Obtevese que os licenciandos ao descreverem e refletirem sobre sua atuação, revelavam um 
encadeamento de ideias que expressava um planejamento cuidadoso da sua prática docente, em que se evidenciou a elaboração de saberes didáticos gerais, sobre o currículo em geral, sobre o currículo específico, saberes didáticos pessoais e sobre o contexto. De acordo com Moraes ...

\section{[...] o licenciando, na dinâmica das interações que estabeleceu, construía seu conhecimento pedagógico do conteúdo em um amálgama de saberes, que foram se constituindo desde sua visão sobre a prática em contraponto com a teoria, e por meio de processos cíclicos de reflexão e ações subsequentes (MORAES, 2010, p. 259).}

Além disso, a autora considera que as visões de mundo dos licenciados definem sua posição epistemológica frente à construção de seus conhecimentos e saberes. Os processos reflexivos ocorridos em diferentes contextos colaboram à elaboração e reafirmação de conhecimentos e saberes docentes e que a formação inicial representa uma etapa do desenvolvimento profissional. Desta forma, não é possível prever de que forma os conhecimentos e saberes iniciais poderão, ou não, repercutir em sua futura prática docente.

Ampliando nossa visão, para demais trabalhos nacionais que abordam a temática de saberes docentes, realizamos uma pesquisa em seis periódicos da Área de Ensino de Ciências na tentativa de observar as tendências dos estudos sobre saberes docentes envolvendo professores de Ciências. O levantamento foi realizado abarcando o período de 2000 a 2011 e a busca efetuada pela verificação dos termos "saber docente" e "saberes docentes" nos títulos dos trabalhos e palavras-chave. Foram identificados seis trabalhos (Quadro 1), o primeiro foi publicado no ano de 2001 e até o ano de 2006 nenhuma publicação foi identificada, sendo em 2007 e 2009 identificados um trabalho em cada ano.

O fato de a nossa pesquisa ter se pautado na busca de trabalhos que tivessem em seu título ou palavras-chave as expressões anteriormente explicitadas pode ter contribuído à localização de pouco trabalhos. As referências dos trabalhos estão apresentadas no Apêndice 1. 
QUADRO 1: PERIÓDICOS ANALISADOS E QUANTIDADE DE TRABALHOS IDENTIFICADOS QUE ABORDAVAM A TEMÁTICA DE SABERES DOCENTES.

\begin{tabular}{l|c|c}
\hline \multicolumn{1}{c|}{ Periódicos } & $\begin{array}{c}\text { Número de } \\
\text { trabalhos }\end{array}$ & $\begin{array}{c}\text { Ano de } \\
\text { publicação }\end{array}$ \\
\hline \hline Ensaio Pesquisa em Educação em Ciências & 2 & 2009 \\
\hline Investigações em Ensino de Ciências & 2 & 2001 e 2007 \\
\hline Química Nova & 0 & - \\
\hline Ciência \& Educação & 1 & 2010 \\
\hline $\begin{array}{l}\text { Revista Brasileira de Pesquisa em Educação em } \\
\text { Ciências }\end{array}$ & 1 & 2011 \\
\hline Caderno Brasileiro de Ensino de Física & 0 & - \\
\hline
\end{tabular}

Quanto à área de enfoque dos trabalhos tivemos três na área de professores de Física, dois em Ciências (com foco nas Ciências do Ensino Fundamental), um em Química e um em Biologia. Destacamos que um mesmo artigo englobava a Área de Ciências e Biologia. As áreas com maior número de artigos publicados são as de Física e Ciências. Em relação à produção de acordo com o foco temático os trabalhos envolviam o estudo de saberes docentes desenvolvidos pelos professores e/ou futuros professores no ambiente escolar, e mais especificamente alguns abordaram os saberes disciplinares e experienciais.

No trabalho de Campos e Diniz (2001), os autores realizaram uma pesquisa com o intuito principal de levantar dados sobre os saberes que professores possuem e que seriam decorrentes de sua prática profissional. Os autores identificaram, por meio de análise de entrevistas realizada com 20 professores de Ciências e 23 de Biologia, três dimensões da aprendizagem dos professores, a saber: "Os professores aprendem sobre sua profissão: a dimensão profissional", "Os professores aprendem a ensinar: a dimensão pedagógica" e "Os professores aprendem sobre suas características e comportamentos: a dimensão pessoal.

Na primeira dimensão identificaram cinco diferentes campos: condições de trabalho, satisfação profissional, relação teoria e prática, aspectos políticos e percurso profissional. Na segunda dimensão que envolve a questão pedagógica têm-se os aspectos metodológicos e as características dos alunos e na dimensão pessoal identificaram o campo emocional/afetivo e o cognitivo. Os autores (CAMPOS e 
DINIZ, 2001) destacam a importância dos professores reconhecerem sua prática como fonte de aprendizagem, em que devem sentir-se como sujeitos ativos e interativos, movidos por diferentes aspectos. Neste contexto adquirem ou aprimoram habilidades, superando o caráter pouco sistematizado, rígido e individual do saber da experiência, de maneira a articular os diferentes conhecimentos teórico-científico e experienciais. Características estas as quais pretendemos na nossa pesquisa obter por meio da dinâmica de formação ocorrida no estágio.

Laburú, Barros e Kanbach (2007) estudaram a pouca utilização de atividades experimentais nas escolas de maneira a fazer uma relação do professor com o seu saber profissional. Para isso entrevistaram três professores de Física do Ensino Médio, os quais tinham de 12 a 13 anos de experiência em sala de aula e haviam em sua graduação cursado a disciplina "Instrumentação para o Ensino do curso da licenciatura em Física". Os dados revelaram que o "fracasso experimental" ocorrido na sala de aula, é decorrente em certa frequência, de um tipo de relação com o saber profissional de simples emprego e não de vocação, em que o professor apenas desempenha sua função profissional como um meio de sustento. Os autores indicam a necessidade de nos cursos de formação de professores ocorrerem reflexões destes com seu saber profissional.

Arruda, Lima e Passos (2011) elaboraram um sistema didático para analisar a ação do professor em sala de aula, em que analisaram as relações com o saber docente em sala de aula. O instrumento é constituído de uma tabela em forma de uma matriz 3x3 em que aborda as interações ocorridas durante a aula sendo as relações do professor com o conteúdo, do professor com o ensino e do professor com a aprendizagem. Tais segmentos são analisados em três dimensões a da relação epistêmica, pessoal e social. O instrumento foi utilizado na análise de entrevistas realizadas com três licenciandos que cursavam a disciplina de Estágio Supervisionado III, uma das disciplinas da grade curricular do curso de licenciatura em Física.

A análise dos dados revelou que o sistema didático possibilitou obter um perfil de cada um dos estagiários entrevistados, no que diz respeito às gestões da relação com o saber em sala de aula. Revelou que estes apresentam como 
preocupação principal o ensino e sua atuação como docente. Os autores sugerem que o sistema elaborado possa ser utilizado como instrumento para diagnóstico e planejamento na formação de professores.

Os pesquisadores Baccon e Arruda (2010) estudaram a construção de saberes docentes, de cinco licenciandos de Física durante a realização do Estágio Supervisionado. Da análise dos dados obtidos por meio de entrevistas, os autores identificaram que o estágio foi a primeira experiência dos licenciandos como professor e que permitiu desenvolver seus primeiros saberes docentes experienciais, os quais estão compilados no Quadro 2. Os autores observaram que a elaboração dos saberes estava diretamente relacionada à personalidade, à maneira de ser e como os licenciandos reagiam frente aos desafios apresentados pelos alunos, independentemente da interferência e da presença ou da ausência do professor. Além disso, as atitudes e comportamentos dos alunos também podem influenciar na formação dos estagiários, dificultando ou facilitando o exercício da função de professor.

QUADRO 2: TIPOS DE SABERES ELABORADOS A PARTIR DA EXPERIÊNCIA DO ESTÁGIO. FONTE: BACCON E ARRUDA (2010).

\begin{tabular}{c|l}
\hline $\begin{array}{c}\text { Tipos de } \\
\text { saberes }\end{array}$ & \multicolumn{1}{c}{ Características } \\
\hline $\begin{array}{c}\text { Saber o } \\
\text { conteúdo }\end{array}$ & $\begin{array}{l}\text { Refere-se à preocupação com o domínio do conteúdo de Física, para } \\
\text { melhor transmiti-lo aos alunos ou para realizar uma transposição } \\
\text { didática mais adequada. }\end{array}$ \\
\hline $\begin{array}{c}\text { Saber } \\
\text { ensinar }\end{array}$ & $\begin{array}{l}\text { Refere-se ao ato de ensinar, ao saber pedagógico e curricular; ao } \\
\text { saber transmitir e trabalhar os conteúdos no cotidiano dos alunos; } \\
\text { saber preparar aulas utilizando diferentes recursos, saber organizar e } \\
\text { distribuir o tempo no momento de ensino. }\end{array}$ \\
\hline interagir & $\begin{array}{l}\text { Refere-se ao saber interativo, saber relacionar-se com os alunos e } \\
\text { sustentar essa relação; saber gerenciar as relações subjetivas na sala } \\
\text { de aula, intervindo apropriadamente no momento da ação. }\end{array}$ \\
\hline $\begin{array}{c}\text { Saber } \\
\text { pessoal }\end{array}$ & $\begin{array}{l}\text { Refere-se a um saber personalizado, que permite conduzir } \\
\text { satisfatoriamente o processo de aprendizagem, apesar das condições } \\
\text { adversas, das queixas e falta de interesse dos alunos; saber lidar com } \\
\text { seus problemas pessoais, sua frustração, com a insatisfação e, mesmo, } \\
\text { rejeição dos alunos, com as situações inesperadas da sala de aula e da } \\
\text { vida na escola. }\end{array}$ \\
\hline $\begin{array}{c}\text { Refere-se a um saber existencial, relacionado ao estilo e modo de ser } \\
\text { do professor, sua identidade docente e reconhecimento pelos pares; } \\
\text { tem a ver com a forma como se comporta diante dos problemas, sua } \\
\text { flexibilidade, autoridade, tato, autoconhecimento; é um saber sobre } \\
\text { ser professor, sobre como se comportar como professor. }\end{array}$ \\
\hline
\end{tabular}


Langhi e Nardi (2010) investigaram os saberes disciplinares de professores dos anos iniciais do ensino fundamental sobre Astronomia. Os resultados apontaram a necessidade de uma melhor qualificação docente em relação a esses saberes, as metodologias de ensino e demais saberes docentes. Resultado semelhante, porém com outro público de professores, foi encontrado no trabalho de Zanon, Oliveira e Queiroz (2009), em que os autores analisaram as visões de alunos de pós-graduação sobre as necessidades formativas de professores de Química do Ensino Superior. No referido estudo identificou-se que os pós-graduandos enfatizam a necessidade do professor conhecer a matéria a ser ensinada e destacam em menor grau a importância dos saberes relacionados com a metodologia de ensino da referida área.

Vimos nesses artigos, ainda que em uma amostra limitada de trabalhos, de que estudos de diferentes naturezas estão sendo realizados envolvendo saberes docentes de professores de Ciências Exatas. Podemos mapear estes estudos nas seguintes frentes: a) Identificação dos saberes desenvolvidos por professores em processo de formação inicial e em exercício docente, de igual objetivo há trabalhos que têm como foco os formadores de professores que atuam nos contextos supracitados e b) Desenvolvimento de estratégias realizadas com professores em diferentes contextos de formação, na busca de suscitarem a elaboração de saberes docentes no que se refere ao ensino de Ciências.

O nosso trabalho vem a contribuir com as pesquisas que envolvem a formação inicial de professores. Buscaremos desenvolver uma metodologia, atrelada a disciplina de Prática do Ensino de Química, que possa criar um ambiente favorável à elaboração de saberes docentes que envolvem a argumentação científica e entender os movimentos reflexivos e o processo de elaboração dos referidos saberes. 


\section{ARgumentaÇÃo no EnSINO de CIÊNCIAS}

Pesquisas em educação (COLOMBO et al, 2012; VILLANI e NASCIMENTO 2003; LEMKE, 2006; SÁ e QUEIROZ, 2009; JIMÉNEZALEIXANDRE e BUSTAMATO, 2003; CAAMAÑO, 2010) têm mostrado a importância da argumentação científica no processo de ensino-aprendizagem em aulas de Ciências. Procuraremos nesta seção apresentar alguns destes trabalhos, os quais nos deram embasamento para a elaboração desta investigação.

\subsection{Uma introdução: A argumentação no Ensino de Ciências}

É de destaque o papel da linguagem como elemento fundamental para a aquisição do conhecimento científico escolar na área de Ciências. Considera-se em trabalhos como o de Lemke (2006), que aprender Ciências significa se apropriar do discurso científico, isto é, aprender como determinados termos se relacionam entre si e com o contexto em que são utilizados para produzir significados específicos.

As perspectivas acima mencionadas convergem quanto à necessidade de ampliar o conceito de Educação em Ciências e da necessidade de considerar o papel da linguagem nesta área do conhecimento para o seu processo de ensino e aprendizagem (VILLANI e NASCIMENTO, 2003). Desta maneira, entende-se que o conhecimento científico não se faz só de palavras com significados específicos, mas de uma linguagem própria capaz de tornar possível o seu aprendizado e, 
principalmente, o seu desenvolvimento. Assim, ter domínio desta linguagem é essencial tanto para a prática das Ciências quanto para o seu aprendizado (VILLANI e NASCIMENTO, 2003).

Uma competência que colabora na aquisição da linguagem científica é o saber argumentar, já que para isto é necessário escolher entre diferentes opções e raciocinar com base em dados empíricos ou em outras fontes, as quais permitem avaliar a opção escolhida como mais adequada (SÁ e QUEIROZ, 2009; JIMÉNEZ-ALEIXANDRE e BUSTAMANTE, 2003). Além disso, a capacidade de argumentação permite relacionar explicações e provas, usando-as para avaliar enunciados, teorias e modelos, contribuindo na construção do entender das Ciências (JIMÉNEZALEIXANDRE, 2010).

A argumentação científica, ou seja, a justificação de afirmações em Ciências a partir de evidências é um aspecto de suma importância para o entendimento e avanço da ciência. Ela possibilita também a compreensão dos conceitos e a Natureza da Ciência (AUFSCHNAITER et al, 2008; CAAMAÑO, 2010), e pode ajudar os alunos a verem a ciência como um processo social e epistemológico em que o conhecimento é gerado, adaptado, reorganizado e às vezes refutado (EVAGOROU e OSBORNE, 2013).

No entanto, a ciência muitas vezes é apresentada nas aulas sem considerar os aspectos acima mencionados. Além disso, em geral, a interação verbal que predomina no contexto escolar é a do tipo Iniciação-Resposta-Avaliação (IRA). Na iniciação, o professor faz uma pergunta, os alunos respondem e depois o professor avalia a resposta e se quer dar continuidade à atividade faz uma nova pergunta.

Embora, o tipo de interação IRA seja útil para determinados propósitos, não permite discussões aprofundadas em que as ideias dos estudantes e do professor possam ser contrastadas e negociadas. Além disso, não possibilita que os estudantes falem entre si e nem que tenham um espaço para o debate e a comunicação de ideias, o que dificulta a aprendizagem dos conceitos e da compreensão da Natureza da Ciência (CAAMAÑO, 2010).

Em uma aula em um contexto de natureza argumentativa é possível também trabalhar com debate sobre temas sociocientíficos, pois o processo de argumentar 
requer que os estudantes sejam capazes de opinar e chegarem a conclusões a partir de evidências e comparar e avaliar seus argumentos em relação com outras possíveis argumentações. Trabalhar com temas sociocientíficos torna-se importante, pois possibilita também que os alunos sejam capazes de distinguir um bom argumento de um que não seja, o que o contribui para tomada de decisões (CAAMAÑO, 2010).

Os assuntos sociocientíficos fazem referências a debates, polêmicas, dilemas e controvérsias que apresentam mútua relação entre a ciência e sociedade. São assuntos de natureza controversa, de debate público e objetos de influencias políticas, éticas e econômicas em relação com as decisões que sobre tais dilemas se tomam. (HENAO e STIPCICH, 2008).

Diante do exposto, percebe-se que a argumentação deve ser considerada como uma ferramenta valiosa no processo de ensino-aprendizagem das ciências, sendo facilitada quando os estudantes resolvem problemas autênticos ou relevantes, de maneira a colaborar na formação de um cidadão com um maior compromisso social. (ARCHILA, 2012).

Fica evidente que promover a argumentação dos alunos em sala de aula é uma atividade de suma importância. No entanto, de igual importância é a necessidade de se analisar os elementos e qualidade dos argumentos. Visando contribuir com estes aspectos, pesquisadores como Toulmin (2001), Jimenez-Aleixandre (2010) e Simon, Erduran e Osborne (2006), entre outros, se dedicaram e têm se dedicado a estudá-los. Faremos uma breve apresentação dos modelos preconizados por esses pesquisadores.

Iniciamos nossa apresentação com o trabalho de Stephen Toulmin (2001), que embora tenha estudado a argumentação mais em um contexto jurídico, trouxe grandes contribuições à área de Ensino de Ciências, de maneira que é comum encontrarmos produções científicas fazendo menção ao seu estudo. Toulmin (2001) estudou a estrutura e validade de argumentos em diferentes áreas e concluiu que há alguns elementos presentes na argumentação que são comuns nos diferentes campos, sendo eles: Dado, Justificativa, Refutador, Backing ou Conhecimento Básico, Qualificador e Conclusão (SÁ e QUEIROZ, 2009; JIMÉNEZ-ALEIXANDRE, 2010). 
Segundo Toulmin uma argumentação tem uma estrutura básica composta pelos Dados, Justificação e Conclusão (SOLBES, RUIZ e FURIÓ, 2010). Tal estrutura pode ser representada da seguinte forma: "a partir de Dado, já que Justificativa, então Conclusão". Porém, para que o argumento seja completo, é preciso especificar em que condições a justificativa apresentada é ou não válida e indicar um peso a ela, acrescentando-se assim os qualificadores. Estes são especificações das condições necessárias para que a Justificativa seja válida.

As justificativas podem ser garantidas por leis jurídicas ou científicas que as fundamentem, sendo esse processo denominado de backing ou Conhecimento Básico (SÁ e LINHARES, 2009). Pode-se também refutar os qualificadores por meio de refutadores que são as condições capazes de invalidar ou refutar a conclusão. A Figura 1, representa o esquema apresentado por Toulmin para relacionar os elementos básicos da estrutura da argumentação.

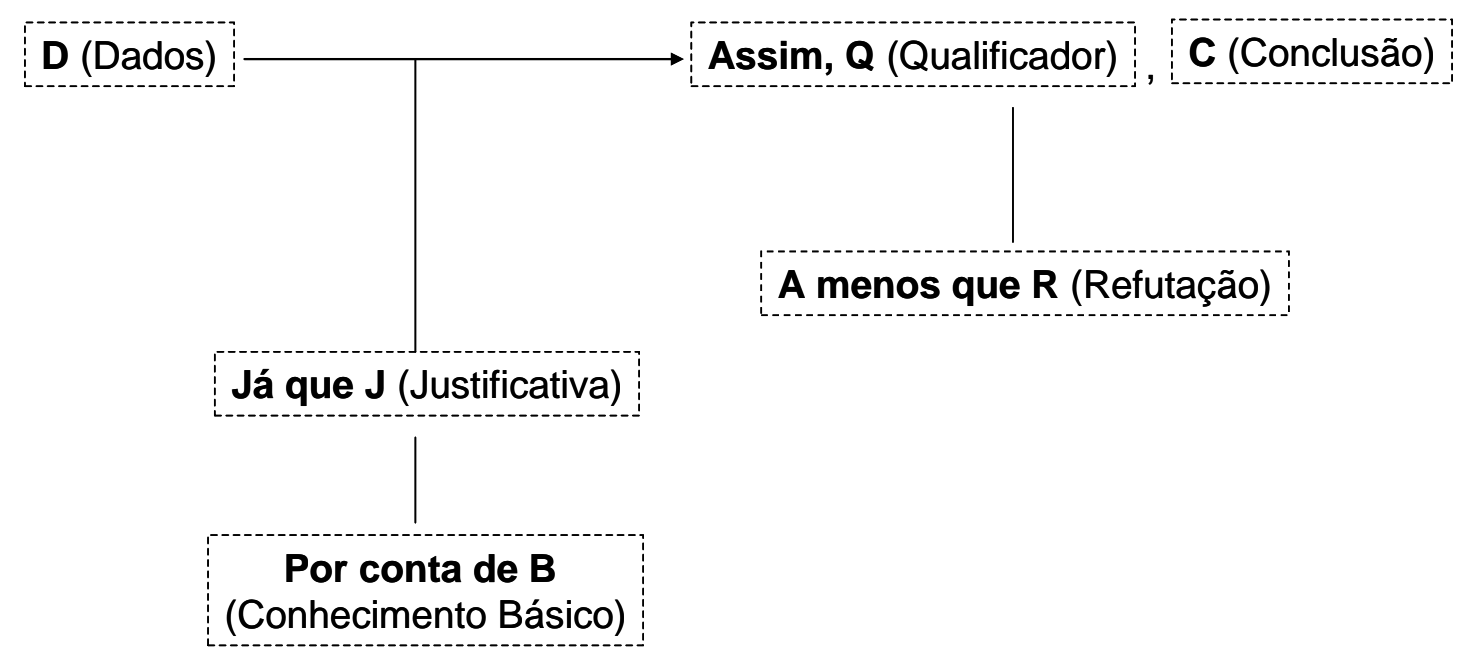

Figura 1: Esquema do Modelo de Toulmin AdAPTAdo de SÁ e QueIROZ (2009).

Nos trechos subsequentes mostraremos uma definição mais ampla de cada elemento do modelo de Toulmin, a começar pelos Dados os quais são informações com o fim de chegar à solução de um problema ou a comprovação de um enunciado (JIMENEZ-ALEIXANDRE, 2010). Embora às vezes se pense nos Dados em termos de números e porcentagens, existem os que são informações qualitativas. 
Quanto aos elementos, a maioria dos alunos tem dificuldade em relacionar Dados com Conclusões. Isso pode ocorrer por diferentes fatores, pois, como os alunos às vezes não identificam as provas relevantes, não sabem relacioná-las ou não reconhecem o modelo ou explicações que emergem das provas disponíveis. Para exercitar o uso de provas é necessário desenvolver atividades em que se promove a construção de justificações a partir delas e não seja considerada como válida uma simples opinião. Esse processo de construção de argumentos, seja em forma de explicações, tomada de decisões ou crítica do enunciado, favorece a construção pelo aluno das explicações científicas (BRAVO e JIMENEZ-ALEIXANDRE, 2010).

A Justificativa é o elemento do argumento que relaciona a Conclusão com os Dados. O seu papel é mostrar que a conclusão que foi feita a partir dos Dados é adequada e legítima. No entanto, os qualificadores e as refutações dão os limites de atuação da Justificativa, complementando a relação entre Dado e Conclusão (VILLANI e NASCIMENTO, 2003). O Backing ou Conhecimento Básico é o que dá a sustentação a justificativa, por meio de conhecimento teórico ou empírico, modelos, leis ou teorias (JIMÉNEZ-ALEIXANDRE, 2010)

O Qualificador Modal é um elemento que também pode modular o argumento. Ele expressa o grau de certeza ou incerteza de um argumento, e outras condições que supõe uma modificação do enunciado, por exemplo, representa os termos: provavelmente, previsivelmente, depende, com segurança e sempre (JIMÉNEZ-ALEIXANDRE, 2010). A Refutação é o elemento que determina as condições para que uma dada Justificativa não seja válida ou suficiente para dar suporte à Conclusão (VILLANI e NASCIMENTO, 2003). Este último elemento é o enunciado do conhecimento que se pretende provar ou refutar, que pode estar relacionado também a uma hipótese.

Estes são os elementos básicos que constituem um argumento em uma visão de Toulmin (2001). A partir deles, pesquisadores fizeram combinações na busca de ampliar a análise do argumento. Dentre os estudos, temos o de Jimenez-Aleixandre, Castro e Pérez (1998), que em seu modelo de análise identificam todos os componentes do argumento de Toulmin nas falas dos alunos, mas específicam os 
diferentes tipos de Dados, afirmações ou enunciados que podem compor os argumentos numa aula de Ciências.

Os autores propõem a criação de subcategorias específicas em relação ao elemento Dado, que pode ser caracterizado como um Dado Fornecido, por exemplo, fornecido pelo professor, livro texto e/ou roteiro de experimento) ou como um Dado Obtido, o qual pode ser classificado como um Dado Empírico, por exemplo, dados que procedem de uma experiência no laboratório ou como Dado Hipotético (VILLANI e NASCIMENTO, 2003; CAPECHI e CARVALHO, 2000). Os Dados Hipotéticos são aqueles fornecidos aos alunos em um problema ou atividade, como mostrado em Jimenez (2010): Dado Hipotético - composição de um alimento, os Dados Empíricos obtidos pelos próprios alunos, por exemplo, a evolução do aumento da temperatura da água até o início da ebulição (JIMÉNEZ-ALEIXANDRE, 2010). $\mathrm{Na}$ fala dos alunos podem ser obtidos também os dados Fornecidos por eles e os Recuperados provenientes do conhecimento prévio que possuem sobre o assunto.

Outro modelo que tem como base o estudo de Toulmin é apresentado por Erduran, Simon e Osborne (2004). Neste modelo, a qualidade dos argumentos é avaliada a partir da combinação dos componentes dos argumentos do padrão de Toulmin (2001), nas falas e textos escritos produzidos pelos alunos. Assim, as combinações que possuem o maior número de componentes são típicas de um argumento mais elaborado. Desta maneira, temos combinações de argumentos com ordem crescente de complexidade conforme pode ser observado no Quadro 3.

QUADRO 3: ORDEM CRESCENTE DE COMPLEXIDADE DOS ARGUMENTOS DE ACORDO COM O MODELO DE ERDURAN, SIMON E OSBORNE (2004).

\begin{tabular}{l|c}
\hline \hline \multicolumn{1}{c|}{ Combinação dos elementos } & $\begin{array}{c}\text { Código da } \\
\text { combinação }\end{array}$ \\
\hline \hline Conclusão/Dado/Justificativa & CDJ \\
Conclusão/Dado/Justificativa/Backing & CDJB \\
Conclusão/Dado/Justificativa/Refutação & CDJR \\
Conclusão/Dado/Justificativa/Qualificador Modal & CDJQ \\
Conclusão/Dado/Justificativa/Backing/Qualificador Modal & CDJBQ \\
Conclusão/Dado/Justificativa/Backing/Qualificador modal/ & CDJBQR \\
Refutador & \\
\hline
\end{tabular}


No ambiente argumentativo de aula de Ciências os processos de raciocínio são explicitados, os estudantes apoiam suas afirmações em provas e avaliam distintas opções, as quais são facilitadas quando o aluno forma parte de uma comunidade de aprendizagem (JIMÉNEZ-ALEIXANDRE, 2010). Esses processos de pensamento tornam-se públicos mediante a linguagem e assim como a argumentação ao requerer raciocínios orais ou escritos também contribui à competência de comunicação linguística, assumindo um papel como instrumento de comunicação.

Para promover um ambiente argumentativo em sala de aula é necessário desenvolver e colocar em prática atividades estruturadas em torno da resolução de problemas e de investigações. É difícil que haja discussão sobre questões de Ciências de forma argumentativa em aulas em que há pouca ou nenhuma interação entre os estudantes e em aulas que são escassas as oportunidades para resolver problemas autênticos, contextualizados e/ou para discutir questões relevantes de Ciências. Desta forma, para analisar a forma que os estudantes desenvolvem argumentos é necessário criar ambientes de aprendizagem em que precisem resolver problemas, investigar, comparar as soluções dadas por distintas equipes e justificar suas opções (JIMÉNEZALEIXANDRE, 1998; GARCIA, DOMÍNGUEZ CASTIÑEIRAS e GARCÍARODEJA, 2002).

Consideramos também que para a suscitação de argumentos é necessário criar ambientes de aprendizagem que requeiram dos alunos a resolução de problemas autênticos. A argumentação nas aulas de Ciências deve proceder de maneira que as discussões possibilitem a construção de explicações coletivas para os fenômenos. Além disso, deve gerar conflitos cognitivos nos alunos, para que tenham consciência de suas ideias, busquem razões para sustentá-las e as comparem com aquelas apresentadas por seus colegas e até mesmo pelo seu professor.

A argumentação pode realizar-se em distintos contextos como teóricos, empíricos, escolha de modelos explicativos, tomada de decisões, confirmações de predições ou avaliação crítica dos enunciados. Em alguns casos, a argumentação não tem implicações sociais, enquanto que há situações em que além das dimensões científicas há um debate social (JIMÉNEZ-ALEIXANDRE, 2010). A argumentação pode oferecer uma visão para que se entenda melhor a própria racionalidade da 
Ciência, analisando seu processo de construção, o contexto de descobrimento para a geração de hipóteses e de justificação para comprová-las e validá-las (SARDÁ, 2000).

Jiménez-Aleixandre (2010) apresenta três tipos de objetivos que podem ser alcançados com a argumentação em sala de aula, sendo que os dois primeiros possuem um caráter transversal enquanto que o terceiro é mais relevante para a aprendizagem de Ciências. Embora sejam apresentados em uma sequência os objetivos podem permear de forma conjunta os diferentes momentos em sala de aula.

O primeiro objetivo está relacionado com a melhoria dos processos de aprendizagem, ou seja, em aprender a aprender, já que contribuem a regulação dos processos de fazê-los públicos e ajudam a desenvolver a competência em comunicação linguística. A competência de aprender a aprender supõe a capacidade para continuar a aprender por toda a vida de maneira eficaz e autônoma.

O segundo objetivo foca na formação de um cidadão responsável, capaz de participar de decisões sociais exercendo o pensamento crítico, como a capacidade de desenvolver uma opinião independente, de refletir sobre a realidade e participar em sua melhora. O terceiro objetivo está voltado ao desenvolvimento de competências relacionadas com as formas de trabalhar da comunidade científica, com o desenvolvimento de ideias sobre a natureza da Ciência que mostrem sua complexidade o que se relaciona com a cultura científica. Além disso, consideramos que a participação dos alunos em ambientes argumentativos os ajudam a aprender a se comunicar, a falar e escrever usando linguagens científicas.

Um dos problemas encontrados quando se trabalha em sala de aula com a argumentação é que os alunos possuem certa dificuldade em relacionar os dados com as conclusões o que gera argumentações pobres. Acar e Roychoudhury (2010) propõem para a melhoria desse quadro a incorporação de atividades em que os alunos tenham que tomar decisões e possam considerar seus valores sobre um problema sociocientífico, avaliando as alternativas à luz das evidências.

Resultado convergente foi identificado por Dawson e Venville (2009) que por meio de entrevistas semiestruturadas, analisaram a argumentação e o raciocínio informal sobre biotecnologia de estudantes australianos de 12 a 17 anos. As 
transcrições foram analisadas utilizando o padrão de argumentação de Toulmin e padrões de raciocínio informal (racionais, emotivos e intuitivos). Os resultados evidenciaram que a maioria dos estudantes não usou dados para justificar suas conclusões e que utilizam a intuição emotiva informal mais frequentemente do que a racional e que o raciocínio informal foi associado com argumentos mais sofisticados (DAWSON e VENVILLE, 2009).

Outros autores, que utilizaram o modelo de Toulmin foram Garcia e Valeiras (2010), analisaram as dificuldades e as potencialidades que os estudantes ao terminarem o Ensino Fundamental na Argentina têm em relação à leitura e a escrita argumentativa. Para isso, propuseram uma série de questões como instrumento para refletir sobre esses processos durante as aulas. Para isso analisaram produções realizadas em aulas de Ciências usando o referido modelo, focando-se nos Dados, nas Conclusões e nas Justificativas. Os autores detectaram que as respostas dos alunos expressavam somente uma Conclusão ou uma relação entre Dados e Conclusão. Tal resultado fez com que os autores sugerissem aos professores destinarem mais tempo e espaços em suas aulas para trabalharem, especificamente, a discussão e a problematização da leitura e escrita científica.

Considerando ainda o contexto de estudar a argumentação em sala de aula, Solbes, Ruiz e Furió (2010) promoveram debates sobre Ciência, Tecnologia e Sociedade em aulas de Física e Química, as quais foram gravadas em vídeo e áudio e juntamente com os trabalhos escritos pelos alunos foram analisadas. A análise foi feita primeiramente identificando os componentes presentes nos argumentos e depois, quanto à qualidade das refutações apresentadas. Como resultado, indicam que os alunos tinham um nível muito baixo de competência argumentativa oral e que os aspectos afetivos influenciam no debate.

Além desses estudos, para uma análise, no contexto nacional de trabalhos sobre argumentação, realizamos uma pesquisa em algumas das principais revistas da área do Ensino de Ciências, no período de 2000 a 2011 e identificamos 18 trabalhos envolvendo a argumentação (Quadro 4). Destacamos que a busca foi realizada considerando a verificação de menções à argumentação ou termos similares nos títulos dos artigos. O Apêndice 2 relaciona os artigos identificados na pesquisa. 
QUADRO 4: PERIÓdICOS ANALISADOS E QUANTIDADE DE TRABALHOS IDENTIFICADOS.

\begin{tabular}{l|c|c}
\hline \multicolumn{1}{c|}{ Periódicos } & $\begin{array}{c}\text { Número de } \\
\text { trabalhos }\end{array}$ & Ano de publicação \\
\hline \hline $\begin{array}{l}\text { Ensaio Pesquisa em Educação em } \\
\text { Ciências }\end{array}$ & 4 & 2002 e 2011 \\
$\begin{array}{l}\text { Investigações em Ensino de } \\
\text { Ciências }\end{array}$ & 5 & $\begin{array}{c}2000,2003,2004, \\
2008 \text { e2010 }\end{array}$ \\
$\begin{array}{l}\text { Química Nova } \\
\text { Ciência \& Educação }\end{array}$ & 1 & 2007 \\
$\begin{array}{l}\text { Revista Brasileira de Pesquisa em } \\
\text { Educação em Ciências }\end{array}$ & 3 & 2009 e 2011 \\
Caderno Brasileiro de Ensino de & 2002,2008 e \\
Física & & 2011 \\
\hline
\end{tabular}

A distribuição dos artigos não é homogênea ao longo do tempo, uma vez que de 2000 a 2004 houve a publicação de um artigo por ano, nos anos de 2005 e 2006 nenhum trabalho foi identificado e a partir de 2007 houve uma variação na quantidade de artigos, sendo o ápice no ano de 2011 com a publicação de 5 artigos. Em relação à área de pesquisa a maioria referia-se a Física (10 trabalhos) e os demais envolviam a área de Ciências, focado no Ensino Fundamental (5 trabalhos), a Química (2 trabalhos) e a Biologia (1 trabalho).

Em relação à produção, de acordo com o foco temático, os trabalhos abarcavam duas naturezas: a interação entre professores e alunos em sala de aula com o intuito de analisar a promoção da argumentação e os argumentos produzidos, e um estado da arte dos trabalhos publicados sobre a temática no período de 2000 a 2009 em revistas da Área de Ensino de Ciências e no Encontro Nacional de Pesquisa em Educação em Ciências (ENPEC). Os trabalhos que focavam a interação professor-aluno foram realizados no âmbito das ações em cursos de formação de professores em que os envolvidos eram os licenciandos e os formadores de professor.

O trabalho de estado da arte publicado por Sá e Queiroz (2011) revelou que a temática argumentação começou a ter considerável importância a partir de 2007, conclusão derivada pelo aumento no número de trabalhos, principalmente nos Encontros Nacionais de Ensino e Pesquisa em Ciências. Tal fato sugere que os 
grupos iniciaram a investigação na temática recentemente, de maneira que há ainda em andamento um processo de consolidação da linha de pesquisa.

Além disso, o referido trabalho revela ainda que as investigações na área de Física são reportadas com mais constância na literatura se comparada às demais áreas e o nível de escolaridade mais privilegiado é do Ensino Médio. Em relação ao foco temático, a maioria dos trabalhos envolve a formação de professores e o desenvolvimento de estratégias promotoras da argumentação. As autoras identificaram a escassa produção no que tange à elaboração de modelos para análise e mecanismos de ensino da argumentação.

Nos demais trabalhos identificados na nossa pesquisa, sete abordavam o modelo de Toulmin, seja ele, como ferramenta a ser utilizada em sala de aula na identificação dos argumentos construídos pelos alunos ou em uma análise dos seus limites e contribuições à área de Ensino de Ciências. Um destes estudos é o de Nascimento e Vieira (2008) que utilizaram o modelo de Toulmin no intuito de refletir sobre as vantagens, limites e contribuições de sua utilização, enquanto ferramenta de análise para as situações argumentativas ocorridas em sala de aula de um curso de formação inicial de professores de Física.

Os autores concluíram que o padrão propicia uma série de possibilidades analíticas, porém com algumas limitações quando da sua aplicação em situações de sala de aula, que provavelmente ocorre pela utilização do modelo fora do seu campo inicial de estudo. No trabalho realizado pelos autores, o padrão foi útil em tornar evidente a gestão do formador no trecho argumentativo analisado, em que o mesmo estabelece, faz circular e avalia as bases da discussão.

Vieira e Nascimento (2007) também publicaram um artigo em que analisam por meio do modelo de Toulmin um episódio de ensino formado por argumentações de licenciandos em Física e o professor formado. Neste episódio ocorreram contraposições de ideias explícitas sobre um domínio de conteúdo específico da mecânica clássica. O uso do referido modelo possibilitou a identificação de alguns elementos discursivos na fala do formador que foram apropriados pelos licenciandos, perceptíveis já que passaram a incorporá-los em seus argumentos. 
Ainda na mesma vertente de usar o modelo de Toulmin na análise de argumentos de licenciandos sobre conceitos de Física, Teixeira, Neto, Freire Jr. e Greca (2010) realizaram um estudo em que concluíram que o modelo foi eficaz para identificar e analisar a qualidade da argumentação construída coletivamente pelos licenciandos. Destacaram que os grupos foram gradualmente complementando o argumento coletivo com agregação de novas garantias, fundamentos, qualificadores e refutadores, o que acentua a importância das atividades para a construção social do conhecimento, porém, o uso do conhecimento básico foi ainda limitado.

Perez, Bebechi, Azevedo, Schreiner, Mattia, Slowik e Oliveira (2011) também utilizaram o padrão de Toulmin, com o intuito de analisar os argumentos produzidos por graduandos de um curso de Ciências Biológicas, os quais tinham que defender determinado ponto de vista sobre os temas "Mercado de Carbono" e “Experimentação Animal". Os autores identificaram que os argumentos dos alunos, em sua maioria, eram compostos de Conclusão-Justificativa e Conclusão-DadoJustificativa em ambos os debates. Tal aspecto remete à conclusão de que os argumentos dos alunos são derivados, principalmente, de opiniões próprias sobre o assunto ou de opiniões formadas a partir de aquisição de fatos aleatórios. Em relação ao momento do debate, os alunos apresentaram uma boa expressividade. Apesar de não formularem os argumentos com base em dados científicos, é necessário incentivar e valorizar nos alunos a importância desse tipo de atividade para o aprimoramento intelectual dos mesmos.

Ainda na vertente de trabalhos que usam o padrão de Toulmin na análise de argumentos produzidos por alunos de cursos do Ensino Superior, temos o estudo realizado por Sá e Queiroz (2007). As autoras analisaram em que medida uma proposta de ensino pautada na resolução de casos foi capaz de estimular a elaboração de argumentos por parte de graduandos em Química e avaliar a qualidade dos argumentos por eles apresentados na resolução dos casos.

O trabalho citado aponta a dificuldade em identificar os componentes do argumento do padrão de Toulmin nas falas dos alunos, em que a principal dificuldade é diferenciar os Dados e Justificativas e Conhecimento Básico. Em relação à estratégia utilizada na promoção da argumentação, as autoras concluíram 
que a natureza do caso tem uma aparente influência em sua resolução e na elaboração de argumentos pelos grupos. Destacam, a necessidade de ensinar aos alunos a "arte" da argumentação, apresentando para eles os componentes do argumento e desenvolvendo estratégias que os levem à produção de bons argumentos.

Ainda no intuito de estudar ferramentas de análise dos argumentos ocorridos em sala de aula Ciências, Sasseron e Carvalho (2011a) apresentaram limites e possibilidades dos referenciais utilizados em pesquisas desta natureza. Focando no modelo de Toulmin, as autoras indicam que o mesmo é uma ferramenta eficaz nos procedimentos de análise das argumentações no ensino de Ciências. Porém há nuances na construção do argumento que precisam ser estudadas, as quais não são abarcadas no modelo de Toulmin.

Em acréscimo as considerações acima, as autoras destacam o papel fundamental do professor na promoção da argumentação em sala de aula, que envolve além de saber fazer perguntas e ouvir os alunos, a necessidade de saber qual o tipo de pergunta que pode e deve ser feita em cada momento da aula. Além disso, defendem que é importante que o professor tenha a compreensão de quando cada um dos elementos do padrão de Toulmin é apresentado nas discussões em sala de aula, e do modo como os significados são negociados até se obter uma ideia que seja aceita por todos e que esteja em conformidade com o conhecimento científico em questão.

As mesmas autoras (SASSERON e CARVALHO, 2011 b) também publicaram um trabalho em que analisam por meio do padrão de Toulmin a construção dos argumentos em sala de aula com alunos do Ensino. No entanto, focam na observação dos indicadores de alfabetização científica ocorridos em aulas de Ciências. O estudo indica a existência de um ciclo argumentativo envolvendo a divulgação da construção do entendimento de um conceito ou de um tema pelos alunos no aparecimento dos indicadores da Alfabetização Científica. O surgimento do ciclo deve-se a alguns fatores como: o cuidado com os Dados existentes os apresentando de maneira que se torne explícita a importância de cada um, a maneira como são trabalhados, ao surgimento das hipóteses, das justificativas e das explicitações. O fim do ciclo caracteriza-se no momento em que 
[...] todas as construções feitas anteriormente são utilizadas com o objetivo de se estabelecerem conexões entre as informações e as variáveis, pois, deste modo, obtém-se uma ideia mais concreta de como os efeitos vistos elou previstos ocorrem. É possível, então, chegar a construções lógicas, objetivas e racionais entre causas e efeitos e, portanto, possuir conhecimentos por meio dos quais os benefícios e prejuízos de cada situação sejam também investigados (SASSERON e CARVALHO, 2011 b, p. 58).

Durante o processo de elaboração do ciclo argumentativo, as autoras (SASSERON E CARVALHO, 2011 b) destacam que foi possível perceber relações entre os indicadores da Alfabetização Científica e o padrão de Toulmin, em que: a) o trabalho com as informações de que os alunos dispõem tem o papel de deixar em evidência o Conhecimento Básico; b) as hipóteses que são trazidas para a discussão estão relacionadas aos Dados; c) a explicação à Conclusão e d) as previsões aos Qualificadores Modais. Para as autoras, a importância destas relações está em que estudando a maneira como os argumentos se constroem em sala de aula e percebendo o ciclo por meio do qual um argumento torna-se cada vez mais completo e coerente, pode-se encontrar bases na orientação para as discussões encaminhadas pelos professores.

Em relação às estratégias utilizadas em sala de aula pelo professor em uma perspectiva da promoção da argumentação, identificamos dez trabalhos os quais tem seu foco em analisar a relação entre a ação do professor em sala de aula, seja ele da Educação Básica ou do Ensino Superior, com a argumentação dos alunos. Em relação à análise em contexto do Ensino Superior temos o trabalho de Vieira e Nascimento (2009, a) que analisaram os Procedimentos Discursivos Didáticos (PDD) que um professor formador utilizou num contexto de formação inicial de professores de Física para gerenciar situações argumentativas de sala de aula.

Os autores identificaram que durante o processo de promoção da argumentação, o formador se posiciona em três papéis: 1) Avaliador de pontos de vista, em que justifica, avalia ou reelabora um posicionamento; 2) Gerenciador de Discussão, em que explicita um posicionamento, sumariza ideias discutidas, enuncia pontos de vistas contrários, elabora feedback eliciativos, interrompe turnos de falas dos licenciandos e apresenta a última palavra do discurso e 3) Ascultador, em que escuta atentamente a fala e a troca discursiva dos alunos. Os PDD identificados são 
aos autores uma unidade discursiva de ação do formador, mesmo que composta de diversos padrões de interações e subcategorias.

Analisando ainda a interação de licenciandos em Física em sala de aula, Nascimento, Platin e Vieira (2008), propõem algumas contribuições sobre os processos de ensino-aprendizagem ocorridos neste contexto, a partir de uma análise dos procedimentos de validação de argumentos. Apontam que o formador pode teorizar ideias intuitivas dos licenciandos de maneira a promover uma racionalidade científica necessária para a prática da docência dos mesmos. Os licenciandos, a partir de episódios dialógicos, podem perceber as dificuldades da transformação das proposições das Ciências Físicas em enunciados da língua natural.

Os autores destacam ainda que na sala de aula a validação do professor não pode ser limitada ao julgamento de falso e verdadeiro das proposições, mas [...] precisa avaliar os argumentos no entorno da "boa" e da "má resposta" e sua relação com a posição interativa do enunciador para incluir o máximo de alunos no jogo argumentativo (NASCIMENTO, PLATIN e VIEIRA, 2008, p. 182). Deve estar atento para que a permanência de dominâncias interativas em sala de aula não silencie vozes importantes para o processo de ensino e aprendizagem, e deve criar sentido nos enunciados, dando-lhes uma validade dentro do domínio do conhecimento científico escolar.

Ainda em relação às estratégias utilizadas em sala de aula pelo professor em um contexto de Educação Básica, temos o estudo de Villani e Nascimento (2003) no qual analisam a influência dos dados empíricos na aprendizagem de alunos que trabalham em grupos em um laboratório didático. Como conclusões, os autores apontam que o laboratório didático tem influencia direta na argumentação dos alunos, por subsidiá-los no discurso, em que os argumentos estão inseridos, com três tipos específicos e distintos de dados: dados fornecidos pelo roteiro; dados empíricos obtidos por meio da atividade experimental e dados resgatados do cotidiano.

Os autores apresentam que há um gênero discursivo específico do laboratório didático, o qual pode ser identificado pela presença de argumentos que utilizam dados empíricos na sua estrutura para contrapor uma opinião defendida por 
argumentos baseados em dados resgatados do cotidiano dos alunos. Nesta direção, esclarecem que:

[...] o laboratório didático introduz elementos específicos, que facilitam o reconhecimento do contexto escolar, e aumentam a probabilidade $e$ a necessidade dos alunos utilizarem argumentos mais adequados e completos, cuja estrutura se aproxima mais da estrutura dos argumentos científicos, em suas respostas a problemas e questões escolares. (VILLANI e NASCIMENTO, 2003, p.206-207)

Capechi e Carvalho (2000) também na linha de analisar a argumentação emergida de atividades de conhecimento físico de cunho experimental, estudaram as interações ocorridas em aulas desta natureza. Identificaram que o discurso da professora na sala seguia um padrão discursivo de Iniciação, Resposta e Feedback. No entanto, tal processo foi realizado de maneira que a professora ao invés de avaliar a resposta do aluno, procurou estimulá-los a acrescentar novas ideias à discussão.

A ação acima citada possibilitou a criação de um espaço cooperativo para a exposição de ideias e a tomada de atitude dos alunos de respeito às diferentes explicações e a autoconfiança para posicionamentos contrários aos dos colegas, assim como a elaboração de argumentos complementares por parte dos alunos. As autoras também identificaram que a atividade de conhecimento físico possibilitou que os alunos apresentassem afirmações com justificativas, relacionando-as aos dados obtidos e elaborassem hipóteses a partir de suas conclusões.

Outro trabalho que envolveu a análise da argumentação em sala de aula foi desenvolvido por Assis e Teixeira (2009). Os autores analisaram a interação ocorrida entre os sujeitos do processo de ensino, professor-aluno, durante a utilização de um texto paradidático em aulas de Física em uma sala de Educação de Jovens e Adultos. Para esta análise os autores utilizaram categorias diferenciadas para analisar a argumentação dos alunos e do professor. Assis e Teixeira (2009) concluíram que o professor teve um papel fundamental no direcionamento da discussão, privilegiou espaços de discussões e viabilizou que os estudantes estabelecessem relações entre os conhecimentos científicos e os de senso comum, bem como a articulação entre os conteúdos científicos e os aspectos sociais, culturais, ambientais e tecnológicos, o que propiciou o interesse dos alunos pela disciplina. 
Também nessa vertente de identificar situações argumentativas Vieira e Nascimento $(2009$, b) desenvolveram um estudo em que apresentam critérios para a identificação destas situações em salas de aulas de Ciências, em que propõem dois critérios marcadores principais para identificá-las, a contraposição de ideias e justificações recíprocas. Padilha e Carvalho (2011) desenvolveram um estudo em que apresentam que a ausência de palavras adequadas nas explicações dos conceitos físicos são superadas pelos alunos a partir do uso integrado de palavras e gestos. Estes últimos complementam o discurso, atribuindo sentido ao que é dito.

Santos, Mortimer e Scott (2001) analisando as interações ocorridas em atividades de debate sobre aspectos sóciocientíficos em aulas de Química do Ensino Médio, concluíram que para o desenvolvimento da argumentação foi fundamental que o professor fizesse perguntas em que os alunos tinham que justificar seus pontos de vista, de maneira a perceberem a necessidade de melhorar a argumentação. No entanto, o estudo indica que há uma dificuldade do professor em conduzir o discurso argumentativo em sala de aula, o que remete a uma necessidade de se desenvolver mais pesquisas que auxilie nesse aspecto. No trabalho de Capecchi, Carvalho e Silva (2002) os autores destacam que a análise das interações discursivas, das diferentes posturas que podem assumir o professor em sala de aula, possibilita a compreensão dos papéis que estas podem representar nas diferentes facetas do ensino, de maneira a contribuir no processo argumentativo.

Podemos inferir que a argumentação apresenta um papel fundamental no Ensino de Ciências, uma vez que: contribui ao entendimento da Natureza da Ciência, ao desenvolvimento de competências relacionadas com as formas de trabalhar da comunidade científica, possibilita à compreensão dos conceitos científicos, o desenvolvimento de diferentes habilidades nos alunos e professores em um contexto das aulas de Ciências, colabora em sua essência ao desenvolvimento de um cidadão que pode ser capaz de atuar criticamente na sociedade nos seus diferentes âmbitos, colabora na melhora dos processos de aprendizagem entre outros benefícios não reportados nesta introdução.

Nas pesquisas reportadas vimos que foram diferentes as estratégias utilizadas tanto para a suscitação da argumentação como para a análise dos argumentos. Quanto 
à promoção de um ambiente argumentativo, as indicações permeiam a necessidade de se criar ambientes de aprendizagem que requeiram dos alunos a resolução de problemas autênticos e investigativos e que colaborem que estes construam seus argumentos (EVAGOROU e OSBORNE, 2013). Além disso, defendemos que os alunos precisam tomar decisões e considerar seus valores sobre problemas em diferentes âmbitos da sociedade e as atividades que participam precisam ter um caráter em que promovam a discussão e a problematização da leitura e escrita científica. 


\section{Objetivos e Metodologia}

Com esta investigação pretendemos aprofundar e gerar conhecimento sobre os cursos de formação inicial de professores da área de Ciências Exatas, desde uma perspectiva das atividades vinculadas ao Estágio Curricular Supervisionado. Estudamos as contribuições de uma dinâmica de formação vinculada ao estágio, ao desenvolvimento de uma prática reflexiva dos licenciandos e a suscitação e compartilhamento de saberes docentes referentes ao uso da argumentação em sala de aula da Educação Básica.

Em vista do nosso propósito, desenvolvemos esta investigação com graduandos de um curso de Ciências Exatas da Universidade de São Paulo. A metodologia de pesquisa foi articulada as atividades de uma disciplina de Prática de Ensino de Química realizadas em um contexto de formação com licenciandos no seu último ano de graduação, e caracterizada como Estudo de Caso.

\subsection{Objetivos}

Buscando respostas às nossas questões de pesquisa iremos nos pautar nos objetivos, a seguir, os quais consideramos que nos dão subsídios para desenvolver esta investigação.

1. Descrever as concepções prévias que estudantes de um curso de Licenciaturas em Ciências Exatas possuem sobre a argumentação e seu 
papel em sala de aula, antes de desenvolverem atividades na disciplina de Prática do Ensino de Química, sobre esta temática.

2. Compreender como licenciandos planejam, ministram e avaliam atividades de regência em que deveriam proporcionar um ambiente favorável à argumentação dos alunos da Educação Básica.

3. Identificar e relacionar a mobilização de saberes docentes dos licenciandos com a dinâmica de formação ocorrida na disciplina de Prática do Ensino de Química vinculada ao Estágio Curricular Supervisionado.

\subsection{Metodologia}

Como abordagem metodológica, utilizamos o Estudo de Caso, o qual é um plano de investigação que envolve o estudo intensivo e detalhado de uma entidade bem definida denominada de caso. Este pode ser um indivíduo, um pequeno grupo, uma escola, um programa etc (ANDRÉ, 1984; COUTINHO e CHAVES, 2002). Na nossa pesquisa, consideramos como caso os fenômenos envolvendo os sujeitos vinculados na disciplina de Prática do Ensino de Química do curso de Licenciatura em Ciências Exatas da Universidade de São Paulo do ano de 2011, os quais tinham como objetivo desenvolver atividades de regência numa perspectiva argumentativa.

Na metodologia de Estudo de Caso ocorre uma interpretação dos fenômenos no seu contexto natural, em que o pesquisador procura descrever sua experiência de forma completa e profunda (ANDRÉ, 1984). No nosso caso, este contexto configurou-se nas aulas da disciplina de Prática do Ensino de Química e das atividades de estágio realizadas em uma escola pública do Ensino Médio da cidade de São Carlos.

Nesta abordagem metodológica utilizam-se diferentes fontes de informação, com as quais se obtém uma variedade de dados coletados em diferentes momentos, possibilitando realizar uma triangulação dos dados. Como fonte de coleta de dados na nossa pesquisa utilizamos observações com anotações em um diário de campo, entrevistas, questionários, registros de áudio e vídeos, relatórios e projetos da regência dos licenciandos e materiais postados no blog da disciplina. 


\subsubsection{Caso Estudado}

A pesquisa foi desenvolvida em uma turma do último ano do curso de Licenciatura em Ciências Exatas com Habilitação em Química. Os licenciandos estavam matriculados na disciplina de Prática do Ensino de Química (PEQ), cujo foco está voltado para a inserção dos mesmos no contexto escolar, por meio de leituras de referencias da área e pelo Estágio Curricular Supervisionado. A seguir, descreveremos o contexto em que a pesquisa foi desenvolvida e os critérios para a escolha do caso.

\section{Contexto da pesquisa}

O Contexto da pesquisa, como já mencionamos, envolve licenciandos do curso de Licenciatura em Ciências Exatas (LCE) da Universidade de São Paulo (USP). O referido curso é sediado no Instituto de Física de São Carlos (IFSC), mas oferecido em conjunto com o Instituto de Química de São Carlos (IQSC) e o Instituto de Ciências Matemáticas e de Computação (ICMC), do campus de São Carlos da USP, sendo ofertado no período noturno com duração de oito semestres.

O objetivo do curso de Licenciatura em Ciências Exatas ${ }^{4}$ é que seus egressos tenham domínio dos conteúdos científicos específicos, das habilidades didáticas diferenciadas e que desenvolvam uma forte visão humanista sobre a educação. Até o ano de 2009, os ingressantes nesse curso cumpriam nos três primeiros anos, um núcleo básico com conteúdos científicos de Física, Química, Matemática e Pedagogia, incluindo três disciplinas anuais de Biologia, tópicos de Astronomia e História da Ciência. No quarto ano, o estudante fazia a opção por uma das três Habilitações - Física, Química ou Matemática - e cursava disciplinas mais específicas da sua área de habilitação, além de realizar um programa de estágio supervisionado.

\footnotetext{
4 Informações obtidas no site do Instituto de Física de São Carlos. Disponível em: http://www.ifsc.usp.br/graduacao/index.php
} 
No ano de 2010 houve uma mudança na grade curricular do curso, de maneira que a opção pela habilitação ocorre no terceiro ano, mas continuando com as disciplinas do núcleo comum. O egresso é habilitado a lecionar na área que optou Física, Química ou Matemática e apto a ministrar aulas de Ciências Físicas e Biológicas para o Ensino Fundamental. Os sujeitos desta pesquisa faziam parte da grade antiga e optaram no quarto ano em cursar as disciplinas requeridas para a Habilitação em Química, dentre as quais está a Prática de Ensino de Química. A referida disciplina tem por objetivo preparar o licenciando ao exercício da docência, a saber: analisar currículos de Química e Ciências, conhecer e saber empregar diferentes metodologias de ensino e de avaliação, elaborar materiais didáticos, realizar o Estágio Curricular Supervisionado, planejar, elaborar e executar minicurso de Química e Ciências entre outros aspectos.

\section{Critério da seleção do caso}

A escolha por realizar o estudo com licenciandos vinculados à disciplina de Prática de Ensino de Química ocorreu devido ao contato da pesquisadora como monitora da mesma, função exercida desde o ano de 2009. A pesquisadora desenvolvia atividades relacionadas ao Estágio Curricular Supervisionado dos licenciandos, as quais incluíam ações no âmbito das escolas e da Universidade tais como: intermediar contatos para realização de convênios em escolas parceiras e campos de estágio, servir de elo entre a universidade e as instituições que sediavam o estágio, encaminhar a documentação específica, contribuir para o estabelecimento de acordo entre as partes, de modo que ambas se beneficiem com o vínculo e colaborar no desenvolvimento das atividades de regência.

Diante do exposto, optamos em realizar a coleta de dados em uma turma na qual já havia contato e na qual os licenciandos já possuíam um vínculo com a pesquisadora. Este aspecto foi importante, pois no decorrer de toda a coleta de dados as atividades foram filmadas e ao final, os licenciandos foram entrevistados, com gravação em áudio e vídeo. Pelo fato da pesquisadora já ter um vínculo com os licenciandos estes, se sentiram à vontade em apresentar suas ideias nos diferentes momentos de pesquisa. 


\subsubsection{Participantes}

Foram sujeitos da pesquisa seis estudantes do curso de Licenciatura em Ciências Exatas que cursavam a disciplina Prática do Ensino de Química no ano letivo de 2011. Para que fizessem parte do estudo, os mesmos assinaram um termo de consentimento em que receberam informações de como seria desenvolvido o estudo e a garantia de seu anonimato. Neste aspecto, com o intuito de preservar a identidade dos mesmos utilizaremos nomes fictícios, os quais serão denominados de Beatriz, João, Marta, Pedro, Rose e Tales.

O Quadro 5 apresenta o perfil relativo à formação dos sujeitos e suas pretensões em relação à carreira docente. Outro aspecto que consideramos na escolha do caso é o fato da pesquisadora ser egressa do curso de Licenciatura em Ciências Exatas, o que despertou um maior interesse em desenvolver atividades neste contexto, como uma maneira de contribuir com o curso que lhe forneceu a base dos seus estudos na sua formação como professora de Ciências e pesquisadora. 
QUADRO 5: PERFIL ESCOLAR E PRETENSÕES FUTURAS EM RELAÇÃO À CARREIRA DOCENTE DOS LICENCIANDOS SUJEITOS DA PESQUISA.

\begin{tabular}{|c|c|c|c|c|c|c|c|}
\hline Sujeito & idade & $\begin{array}{l}\text { Ingresso } \\
\text { ES }\end{array}$ & Profissão & $\begin{array}{l}\text { Formação } \\
\text { escolar }\end{array}$ & $\begin{array}{l}\text { Experiência } \\
\text { como } \\
\text { docente }\end{array}$ & $\begin{array}{l}\text { Interesse em atuar/continuar } \\
\text { atuando como professor }\end{array}$ & Nível de Ensino de interesse em atuar \\
\hline Beatriz & 20 & 2008 & Estudante & $\begin{array}{l}\text { EF: público } \\
\text { EM: público }\end{array}$ & Não tem & $\begin{array}{l}\text { Pretende atuar como docente. } \\
\text { Justificativa: Gosta de transmitir } \\
\text { conhecimento. }\end{array}$ & $\begin{array}{l}\text { EM Particular } \\
\text { Justificativa: Alunos das escolas públicas tem } \\
\text { pouco interesse no estudo. } \\
\text { ES Pública } \\
\text { Justificativa: Os alunos são mais disciplinados. }\end{array}$ \\
\hline João & 25 & 2008 & Estudante & $\begin{array}{l}\text { EF: público } \\
\text { EM: público }\end{array}$ & $\begin{array}{l}\text { Professor de } \\
\text { Química EM } \\
\text { (1 ano) }\end{array}$ & $\begin{array}{l}\text { Tem dúvidas. } \\
\text { Justificativa: Condições atuais } \\
\text { das escolas }\end{array}$ & EM e ES Pública e/ou Particular \\
\hline Marta & 25 & 2006 & $\begin{array}{l}\text { Servidor } \\
\text { público }\end{array}$ & $\begin{array}{l}\text { EF: público } \\
\text { EM: particular }\end{array}$ & Não tem & $\begin{array}{l}\text { Não. Justificativa: Gostaria de } \\
\text { realizar uma pós-graduação } \\
\text { antes. }\end{array}$ & $\begin{array}{l}\text { EM (pública ou privada) } \\
\text { Justificativa: A compreensão dos alunos deste } \\
\text { nível é mais fácil. }\end{array}$ \\
\hline Rose & 23 & 2006 & $\begin{array}{l}\text { Estagiária } \\
\text { empresa } \\
\text { Química }\end{array}$ & $\begin{array}{l}\text { EF: particular } \\
\text { EM: particular }\end{array}$ & Não tem & $\begin{array}{l}\text { Não. } \\
\text { Justificativa: Não gosta de } \\
\text { lecionar e percebeu pelos } \\
\text { estágios que a atuação docente } \\
\text { está cada vez mais difícil. }\end{array}$ & $\begin{array}{l}\text { ES Público e/ou Particular Justificativa: Alunos } \\
\text { deste nível valorizam mais o professor, } \\
\text { colaborando no processo de ensino. }\end{array}$ \\
\hline Tales & 23 & 2008 & Estudante & $\begin{array}{l}\text { EF: público } \\
\text { EM: público }\end{array}$ & Não tem & Sim, após a pós-graduação. & $\begin{array}{l}\text { ES Justificativa: O salário e as condições do } \\
\text { professor do EF e EM. são precários. }\end{array}$ \\
\hline Pedro & 24 & 2007 & Estudante & $\begin{array}{l}\text { EF: público/ } \\
\text { particular } \\
\text { EM: particular }\end{array}$ & $\begin{array}{l}\text { Professor de } \\
\text { Inglês } \\
\text { ano) }\end{array}$ & $\begin{array}{l}\text { Pretende continuar na } \\
\text { profissão. } \\
\text { Justificativa: Acha legal lecionar. }\end{array}$ & $\begin{array}{l}\text { Atuaria em qualquer nível de escolaridade } \\
\text { tendo preferência aos colégios particulares. } \\
\text { Justificativa: Melhores salários. }\end{array}$ \\
\hline
\end{tabular}

Legenda: EF= Ensino Fundamental, EM = Ensino Médio, ES = Ensino Superior 


\subsubsection{Atividades desenvolvidas}

A pesquisa foi desenvolvida em cinco momentos conforme ilustrado no Quadro 6. No primeiro, estudamos as concepções que os licenciandos tinham sobre argumentação, sobre o seu papel em sala de aula e sobre as estratégias de ensino que a favorecem. Neste momento tínhamos como objetivo obter subsídios ao desenvolvimento de atividades sobre argumentação a serem realizadas com os mesmos.

No segundo momento foram desenvolvidas atividades relacionadas ao Estágio de Observação realizado pelos licenciandos em uma escola de Educação Básica. No terceiro, as atividades tinham por objetivo proporcionar aos futuros professores uma base de conhecimento sobre o uso da argumentação em um contexto de ensino-aprendizagem. No quarto momento, os licenciandos desenvolveram e ministraram sua regência e no último tiveram espaços para reflexão da sua prática docente, desde uma perspectiva individual à coletiva. 
QUADRO 6: RELAÇÃO DAS ATIVIDADES DESENVOLVIDAS AO LONGO DA INVESTIGAÇÃO.

\begin{tabular}{|c|c|}
\hline Descrição dos momentos & Atividades desenvolvidas \\
\hline $\begin{array}{c}\text { Primeiro Momento: } \\
\text { Conhecimento prévio dos } \\
\text { licenciandos sobre argumentação }\end{array}$ & $\begin{array}{l}\text { 1.Aplicação de questionário individual } \\
\text { dissertativo para identificar o conhecimento dos } \\
\text { licenciandos sobre argumentação e seu papel } \\
\text { em sala de aula, antes de participarem de } \\
\text { atividades sobre argumentação na disciplina de } \\
\text { PEQ. }\end{array}$ \\
\hline Segundo Momento: & $\begin{array}{l}\text { 1. Realização por parte dos licenciandos do } \\
\text { Estágio de Observação em aulas de Química do } \\
\text { Ensino Médio em escola pública. }\end{array}$ \\
\hline Estágio de Observação & $\begin{array}{l}\text { 2. Postagem dos licenciandos sobre suas } \\
\text { impressões e reflexões do Estágio de } \\
\text { Observação no blog da disciplina de PEQ. }\end{array}$ \\
\hline \multirow{5}{*}{$\begin{array}{l}\text { Terceiro Momento: } \\
\text { Atividades sobre argumentação }\end{array}$} & $\begin{array}{l}\text { 1. Atividade investigativa da prática docente } \\
\text { (primeira parte), por meio da reflexão de vídeos } \\
\text { sobre atividades de conhecimento Físico no } \\
\text { Ensino Fundamental }\end{array}$ \\
\hline & $\begin{array}{l}\text { 2. Oficina de leitura de artigos de periódicos } \\
\text { sobre argumentação em sala de aula. }\end{array}$ \\
\hline & $\begin{array}{l}\text { 3. Apresentação de seminário pela docente da } \\
\text { disciplina de PEQ sobre a importância da } \\
\text { argumentação em sala de aula e os modelos de } \\
\text { análise dos argumentos. }\end{array}$ \\
\hline & $\begin{array}{l}\text { 4. Atividade investigativa da prática docente } \\
\text { (segunda parte), por meio da reflexão de vídeos } \\
\text { sobre atividades de conhecimento Físico no } \\
\text { Ensino Fundamental. }\end{array}$ \\
\hline & $\begin{array}{l}\text { 5. Elaboração de mapa conceitual sobre } \\
\text { argumentação em sala de aula. }\end{array}$ \\
\hline \multirow{5}{*}{$\begin{array}{l}\text { Quarto Momento: } \\
\text { Atividade de regência }\end{array}$} & 1. Elaboração do projeto de regência. \\
\hline & $\begin{array}{l}\text { 2.Espaço para os licenciandos apresentarem } \\
\text { individualmente seu projeto de Regência. }\end{array}$ \\
\hline & 3. Re-elaboração do Projeto de Regência. \\
\hline & $\begin{array}{l}\text { 4. Apresentação Final do projeto de regência na } \\
\text { disciplina de Prática do Ensino de Química. }\end{array}$ \\
\hline & $\begin{array}{l}\text { 5. Implementação da regência na escola de } \\
\text { Educação Básica. }\end{array}$ \\
\hline \multirow{3}{*}{$\begin{array}{l}\text { Quinto Momento: } \\
\text { Reflexão da prática docente }\end{array}$} & $\begin{array}{l}\text { 1. Reflexão individual e coletiva - apresentação } \\
\text { da reflexão da regência durante aulas da } \\
\text { disciplina de Prática do Ensino de Química. }\end{array}$ \\
\hline & $\begin{array}{l}\text { 3. Elaboração de Relatório de regência com base } \\
\text { em orientações. }\end{array}$ \\
\hline & 4. Entrevista individual com os licenciandos. \\
\hline
\end{tabular}




\subsubsection{Instrumentos de coleta de dados}

O Quadro 7 ilustra, de forma resumida, as atividades realizadas com e pelos licenciandos e os instrumentos utilizados para a coleta de dados. Utilizamos questionários, entrevistas, mapa conceitual, registro de materiais na forma de postagens dos licenciandos no blog, projetos e relatórios de regência e gravações em áudio e vídeo das atividades desenvolvidas pelos licenciandos tanto nas aulas da disciplina de Prática de Ensino de Química como nas aulas da Educação Básica.

Teceremos alguns comentários sobre cada tipo de instrumento de coleta de dados com o intuito de apresentarmos os benefícios atrelados a cada um dentro da pesquisa qualitativa e as informações que nos forneceram. Iniciaremos com a entrevista, a qual é um processo de interação social e que ocorreu entre a pesquisadora e os licenciandos, sendo que cada um foi entrevistado individualmente e no ambiente da universidade.

Consideramos na categoria de "Documentos" o questionário aplicado aos licenciandos no começo da investigação, as postagens dos mesmos no blog da disciplina, as quais foram realizadas em diferentes momentos do processo de investigação e os projetos e relatórios de regências. O questionário foi composto de questões dissertativas e versavam sobre o conhecimento dos licenciandos sobre aspectos teóricos da argumentação e da vivência deles sobre esta temática. Antes de aplicarmos os instrumentos aos sujeitos desta pesquisa, o questionário foi apresentado em diferentes momentos ao grupo de Investigação coordenado pela professora Dra. Maria Lucia Vital dos Santos Abib, cujo público são pesquisadores em nível de mestrado e doutorado, que trabalham com o Ensino de Ciências e a Formação de Professores.

O questionário foi inicialmente apresentado no grupo de investigação em que sugestões foram realizadas. Após este momento o instrumento foi aplicado a graduandos do curso de licenciatura, os quais não seriam sujeitos da investigação, mas que apresentavam características semelhantes à população alvo. Uma vez obtidos os resultados, estes foram apresentados ao Grupo de Investigação para novos ajustes no questionário e sua finalização foi aplicado aos licenciandos que fizeram parte desta investigação. 
Quanto às postagens no blog estas envolveram desde relatos do estágio de observação e regência realizados pelos licenciandos, até atividades que realizaram para ampliarem seu conhecimento teórico sobre argumentação. Os projetos e relatórios de regências foram entregues impressos elaborados pelos licenciandos seguindo um roteiro, o qual os guiaram a abordarem os diferentes aspectos que compunham a atividade. Estes instrumentos foram também analisados por pesquisadores das áreas em que esta pesquisa foi desenvolvida.

Esta categoria "Documentos" possibilitou que tivéssemos acessos às impressões ainda recentes dos licenciandos em relação ao estágio, uma vez que após cada dia de atividade tinham que postar suas impressões no blog e um olhar mais distanciado, já que muitos sujeitos comtemplaram em seu relatório aspectos decorrentes do Estágio de Observação. Além disso, pudemos obter acesso ao processo, desde uma visão dos licenciandos, da elaboração, implementação e reflexão das atividades de ensino voltadas a promoção de um ambiente argumentativo em sala de aula, e também ao seu entendimento sobre aspectos teóricos da argumentação, já que algumas ações da etapa de "Atividades sobre Argumentação" foram desenvolvidas via blog da disciplina.

As gravações em áudio e vídeo foram realizadas em diferentes momentos da pesquisa, em que foram comtempladas a gravação de todas as atividades realizadas em sala de aula da disciplina sobre aspectos teóricos da argumentação, das atividades de regência e das destinadas diretamente ao compartilhamento das experiências das ações docentes. As gravações possibilitaram que tivéssemos acesso, já num momento mais distante da ação, detalhes do processo, nos possibilitando analisar o material quantas vezes fossem necessário.

Concordamos com Belei, Gimeniz-Paschoal, Nascimento e Matsumoto (2008), que consideram que por meio da filmagem é possível reproduzir a fluência do processo, ver aspectos do que foi ensinado e apreendido, observar pontos que muitas vezes não foram percebidos no momento da ação e ampliar a qualidade dos dados a serem analisados. Durante a análise das filmagens foi possível registrar as reflexões dos licenciandos, suas linguagens corporais, a entonação das colocações, suas emoções, o posicionamento dos envolvidos no processo, seja na universidade como 
na escola pública, e o clima que envolvia o licenciando nestes diferentes contextos. Registros destas observações foram também realizados pela pesquisadora em um Diário de Campo.

Utilizamos a entrevista na perspectiva de ampliar os nossos dados em relação às atividades com e pelos licenciandos e principalmente de obtermos as impressões de foram falada destes sujeitos em relação às ações sofridas e desenvolvidas no contexto argumentativo. A entrevista foi do tipo semiestruturada, a qual foi direcionada por um roteiro previamente elaborado composto de questões do tipo aberta. Em determinados momentos da entrevista a pesquisadora elucidou questões que os licenciandos apresentaram dificuldades de compreensão.

Antes de realizarmos a entrevista, o roteiro foi previamente analisado por pesquisadores das áreas de Ensino de Ciências e Formação de Professores, os quais faziam parte do grupo de investigação da orientadora deste trabalho, na busca de analisarem se os termos utilizados eram compreensíveis e adequados aos licenciandos. Além disso, buscou-se a identificação de possíveis questões que pudessem gerar dificuldade de interpretação pelos alunos e buscamos analisar se as questões estavam elaboradas de maneira que pudessem obter respostas que contemplassem o objetivo da investigação (BELEI, GIMENIZ-PASCHOAL, NASCIMENTO e MATSUMOTO, 2008). Ao desenvolver as questões, procuramos que estas não tivessem um caráter absurdo, ambíguo, deslocadas, tendenciosas e que levassem em consideração a sequência de pensamento do licenciando, de maneira a seguir um raciocínio lógico para o mesmo (BONI e QUARESMA, 2005).

Faziam parte do instrumento trinta e três questões (Apêndice 6), as quais foram divididas em nove blocos, a saber: Processo de formação, Experiências em relação à argumentação, Concepção sobre atividades argumentativas, Elaboração da regência, Impressão do desenvolvimento da regência, Reflexão em relação à regência, Saberes docentes elaborados no processo de desenvolvimento e execução da regência, Pretensões futuras e Visão geral da prática da disciplina de Prática de Ensino. Além das questões previamente elaboradas, em alguns momentos foi necessária a elaboração de novos questionamentos aos licenciandos, na busca de 
clarificar determinados posicionamentos que expressavam. As entrevistas foram gravadas em áudio e vídeo e posteriormente transcritas.

QUADRO 7: ATIVIDADES REALIZADAS COM E PELOS LICENCIANDOS E OS MATERIAIS OBTIDOS.

\begin{tabular}{|c|c|c|}
\hline Momento & Atividade & Material obtido \\
\hline Primeiro & Questionário & Documento: Questionários respondidos \\
\hline Segundo & Estágio de observação & Documento: Diário do estágio publicado no blog \\
\hline \multirow{5}{*}{ Terceiro } & $\begin{array}{l}\text { Atividade investigativa da prática } \\
\text { docente (Primeira parte) }\end{array}$ & Documento: Texto \\
\hline & $\begin{array}{l}\text { Oficina de leitura de artigos sobre } \\
\text { argumentação }\end{array}$ & $\begin{array}{l}\text { Vídeo: Gravação discussão artigos } \\
\text { Documento: texto no blog }\end{array}$ \\
\hline & $\begin{array}{l}\text { Apresentação do seminário sobre } \\
\text { argumentação }\end{array}$ & Vídeo: Gravação do seminário \\
\hline & $\begin{array}{l}\text { Atividade investigativa da prática } \\
\text { docente (Segunda parte) }\end{array}$ & Documento: Texto descritivo \\
\hline & $\begin{array}{l}\text { Elaboração de mapa conceitual sobre } \\
\text { argumentação }\end{array}$ & Documento: Mapa Conceitual \\
\hline \multirow{3}{*}{ Quarto } & Elaboração do projeto de regência & Documento: Projeto de regência \\
\hline & $\begin{array}{l}\text { Apresentação e re-elaboração do projeto } \\
\text { de regência }\end{array}$ & Vídeo: Gravação de aula \\
\hline & Elaboração do relatório da regência & Documento: Relatório de regência \\
\hline & Reflexão individual e coletiva da prática & Vídeo: Gravação de aula \\
\hline Quinto & Entrevista com os licenciandos & Vídeo: Gravação das Entrevistas \\
\hline
\end{tabular}

\subsubsection{Primeiro momento: Conhecimento prévio dos licenciandos sobre argumentação}

Os licenciandos no começo do ano letivo responderam a um questionário o qual requeria informações relacionadas ao perfil escolar e cinco questões dissertativas (Quadro 8), as quais tinham relação direta com a argumentação. 
QUADRO 8: QUESTÕES APLICADAS AOS LICENCIANDOS PARA IDENTIFICAR SEU CONHECIMENTO PRÉVIO SOBRE ARGUMENTAÇÃO.

\begin{tabular}{l}
\hline \multicolumn{1}{c}{ Questões } \\
\hline \hline Na sua opinião o que é argumentação? \\
\hline $\begin{array}{l}\text { Relate situações que você tenha vivenciado em sala de aula, como } \\
\text { aluno ou como professor em que tenha ocorrido a argumentação. }\end{array}$ \\
\hline $\begin{array}{l}\text { Como você se sente quando passa por situações em que precisa } \\
\text { argumentar em público? }\end{array}$ \\
\hline \begin{tabular}{l} 
Que estratégias dificultam a argumentação em sala de aula e quais \\
favorecem? Por que? \\
\hline O que você pensa sobre incentivar a argumentação dos alunos em \\
sala de aula? Justifique sua resposta.
\end{tabular} \\
\hline
\end{tabular}

\subsubsection{Segundo momento: Estágio de Observação}

Para a realização do Estágio de Observação, os licenciandos acompanharam aulas de Química do Ensino Médio em uma escola pública da cidade de São Carlos. Antecedendo a ida dos licenciandos à referida instituição, foram discutidas nas aulas de Prática de Ensino de Química os objetivos do estágio e a maneira como seria desenvolvido. Os futuros professores receberam um roteiro (Apêndice 3) cuja finalidade era que focalizassem sua observação em aspectos da sala de aula que talvez sem o mesmo não observasse. Optamos por entregar um roteiro, pois o mesmo é um instrumento importante, já que

\footnotetext{
[...] ter um roteiro em mãos não significa limitar-se em responder e refletir sobre o que ali está sendo pedido pode-se ir além, "enxergar" outras possibilidades, sempre em busca de compartilhar experiências, fazer análises, para que assim possam advir reflexões. Além disso, vale destacar que o roteiro, não tem por intenção "ocultar" certos acontecimentos, nem "iluminar" outros, como o próprio nome sugere trata-se de um encaminhamento (BROIETTI e BARRETO, 2011, p. 184).
}

Após cada dia de estágio, os licenciandos publicavam no blog da disciplina na seção "Diário Coletivo de Estágio", suas impressões, observações e reflexões acerca do acompanhamento das aulas. Todas as postagens eram comentadas pela professora ou monitora (pesquisadora) da disciplina e ficavam públicas para que todos os licenciandos tivessem acesso. 
Ao término do primeiro dia de estágio os licenciandos postaram considerações a respeito de aspectos que deveriam ser considerados ao se realizar estágio desta natureza. Tais aspectos foram, em conjunto, discutidos com os licenciandos, a professora e a monitora da disciplina (pesquisadora), buscando identificar e/ou aprimorar as diretrizes a serem usadas na observação na pretensão de um aproveitamento mais significativo dos demais dias de Estágio de Observação.

\subsubsection{Terceiro momento: Atividades sobre argumentação}

Com o intuito de iniciar e/ou ampliar o conhecimento dos licenciandos sobre o uso da argumentação científica em sala de aula, uma série de atividades foram desenvolvidas. Além disso, foram discutidos aspectos teóricos de ações desta natureza. A seguir descreveremos cada etapa realizada.

\section{Atividade investigativa da prática docente (Primeira parte)}

Com o intuito de proporcionarmos aos licenciandos a oportunidade de investigar uma prática docente, apresentamos um vídeo sobre a construção do conhecimento físico em sala de aula para que observassem as estratégias usadas pelas professoras e o processo como o conhecimento científico foi sendo construído pelos alunos. O vídeo "O Problema do Looping" faz parte da série "Atividades de Conhecimento Físico - Física no Ensino Fundamental” produzido pelo Laboratório de Pesquisa e Ensino de Física da Faculdade de Educação da Universidade de São Paulo (LAPEF ${ }^{5}$.

As atividades abordadas no vídeo foram elaboradas de maneira a possibilitar aos alunos do Ensino Fundamental oportunidades de resolverem problemas de Ciências e tomarem consciência das variáveis envolvidas nesta solução, por meio de diálogos argumentativos. A metodologia empregada nestas atividades pode ser caracterizada por alguns momentos. No primeiro, o professor propõe o problema, divide a sala em pequenos grupos e apresenta os materiais da atividade, etapa em que os alunos buscam familiarizar-se com materiais. No segundo momento os alunos argumentam entre si, propondo e testando hipóteses, buscando resolver o problema

\footnotetext{
${ }^{5}$ Disponível em: http://www.lapef.fe.usp.br/
} 
apresentado pelo professor (CAPECCHI e CARVALHO, 2000; COLOMBO et al, 2012).

No terceiro momento é realizada uma discussão (socialização do conhecimento) com toda a sala, em que se tem a formulação das perguntas que buscam a resposta ao "como?" (como foi produzido/resolvido) e "por quê?" (explicações causais). No último momento, os alunos, mediados pela professora, tentam relacionar a atividade com o cotidiano. Durante as atividades os alunos, ao trabalharem sobre propostas, buscam soluções utilizando de uma linguagem cotidiana muito particular que aos poucos, nas explanações com a sala (explicação da resolução do problema), se transforma em uma linguagem mais científica (CARVALHO, 2010). Após assistirem o vídeo, o qual tem a duração de aproximadamente 15 minutos, os licenciandos redigiram um texto cuja orientação consistia em "Elabore um texto apresentando as estratégias utilizadas pelas professoras e como os alunos progrediram em relação à construção do conhecimento".

\section{Oficina de leitura de artigos sobre argumentação científica}

Após a análise do vídeo foi realizada com os licenciandos uma oficina de leitura, a qual foi dividida em cinco etapas conforme Quadro 9. Na primeira foi realizada, pelas formadoras (professor e monitora/pesquisadora) a seleção de artigos sobre argumentação em sala de aula, cujo critério de escolha foi à opção por produções de artigos de periódicos que não fossem extensos, que relatassem experiência do uso da argumentação no cotidiano escolar e que apresentassem diferentes estratégias de ensino que envolvesse a argumentação.

Foram selecionados cinco artigos, os quais têm suas referências apresentadas no

Quadro 10, incluindo a relação de cada licenciando responsável por sua leitura. Todos os artigos foram postados no blog da disciplina. Esta ferramenta ao longo da disciplina serviu como repositório de conteúdos e meio de comunicação entre licenciandos, docente e pesquisadora. 
Na segunda etapa cada licenciando leu um dos artigos, com escolha pessoal, e postou no blog duas perguntas sobre aspectos importantes do mesmo e num período de uma semana escolheram perguntas de um colega e as responderam no blog, consistindo na terceira etapa. Após estas atividades, deu-se a quarta etapa, em que durante uma aula da disciplina os licenciandos discutiram entre si e com a docente responsável pela disciplina as perguntas e respostas para cada artigo, de maneira que houvesse um compartilhamento de ideias entre os envolvidos no processo. Na última etapa os licenciandos construíram coletivamente um texto no blog sobre a argumentação e seu uso em sala de aula, em que se basearam na seguinte orientação:

Com base na leitura e discussão dos artigos apresente aspectos importantes a se considerar quando o professor deseja promover espaços propícios à argumentação em sala de aula (considere as estratégias que podem ou não favorecer a argumentação, a conduta do docente neste tipo de atividade entre outros aspectos).

A construção do texto ocorreu de maneira que inicialmente Beatriz postou algumas considerações sobre os artigos e os demais licenciandos foram sucessivamente postando contribuições à discussão da temática, de maneira que cada postagem vinha a contribuir com as já existentes.

\section{QUADRO 9: FLUXXGRAMA COM A SEQUÊNCIA DE ATIVIDADES REALIZADAS NA OFICINA DE LEITURA} SOBRE ARGUMENTAÇÃO.

\begin{tabular}{c|l}
\hline \multicolumn{1}{c|}{ Etapa } & \multicolumn{1}{c}{ Sequência das Atividades } \\
\hline \hline Primeira & $\begin{array}{l}\text { Seleção dos artigos em periódicos. } \\
\text { Disponibilização dos artigos no Blog da } \\
\text { Disciplina de Prática do Ensino de Química. }\end{array}$ \\
\hline Segunda & $\begin{array}{l}\text { Leitura dos artigos por parte dos licenciandos. } \\
\text { Postagem no Blog pelos licenciandos de } \\
\text { perguntas sobre os artigos. }\end{array}$ \\
\hline Terceira & $\begin{array}{l}\text { Escolha de perguntas e postagem de respostas } \\
\text { dos licenciandos. }\end{array}$ \\
\hline Quarta & $\begin{array}{l}\text { Momento de discussão em sala de aula } \\
\text { (disciplina) para compartilhamento das } \\
\text { perguntas e respostas. }\end{array}$ \\
\hline Quinta & $\begin{array}{l}\text { Construção de texto coletivo no Blog sobre a } \\
\text { temática dos artigos. }\end{array}$ \\
\hline
\end{tabular}


QUADRO 10: REFERÊNCIA DOS ARTIGOS UTILIZADOS NA DINÂMICA DE LEITURA E A RELAÇÃO DOS LICENCIANDOS QUE O LERAM E ELABORARAM PERGUNTAS SOBRE O TEXTO.

\begin{tabular}{l|c}
\hline \multicolumn{1}{c|}{ Referência artigo } & Licenciandos \\
\hline \hline $\begin{array}{l}\text { Chiaro, S.; Leitão, S. O papel do professor na construção discursiva } \\
\text { da argumentação em sala de aula. Psicologia: reflexão e Crítica, } \\
\text { 18(3), 350-377, 2005. }\end{array}$ & João e Rose \\
\hline $\begin{array}{l}\text { Sá, L.; Queiroz, S. L. O. Promovendo a argumentação no ensino } \\
\text { superior de Química. Química Nova, v.30, n.8, p. 2035-2042, 2007. }\end{array}$ & Tales \\
\hline $\begin{array}{l}\text { Altarugio, M. H.; Diniz, M. L. Locatelli, S. W. O debate como estratégia } \\
\text { em aulas de Química. Química Nova na Escola, v. 32, n.1, fevereiro, }\end{array}$ & Beatriz \\
2010. & Marta \\
\hline $\begin{array}{l}\text { Suart, R. C., Marcondes, M. E. R. e Lamas, M. F. P. A Estratégia } \\
\text { "Laboratório Aberto" para a Construção do Conceito de }\end{array}$ & \\
$\begin{array}{l}\text { Temperatura de Ebulição e a Manifestação de Habilidades } \\
\text { Cognitivas. Química Nova na Escola vol. 32, n 3, Agosto 2010. }\end{array}$ & Pedro \\
\hline $\begin{array}{l}\text { Oliveira, A. S. e Soares, M. H. F. B. Júri químico: Uma atividade lúdica } \\
\text { para discutir conceitos químicos. A discussão de conceitos químicos. } \\
\text { Química Nova na Escola, n 21, maio 2005. }\end{array}$ & \\
\hline
\end{tabular}

\section{Apresentação do seminário sobre argumentação}

Após os licenciandos terem lidos artigos e discutidos sobre argumentação a docente responsável pela disciplina ministrou um seminário sobre a temática em que abordou os seguintes aspectos: as diferentes definições de argumentação, a importância desta competência nas aulas de Ciências, as estratégias usadas à promoção da argumentação em sala de aula e os modelos de análise de argumentos.

\section{Atividade investigativa da prática docente (Segunda parte)}

Uma vez que os licenciandos já possuíam um conhecimento sobre argumentação reapresentamos o vídeo "O Problema do Looping” e solicitamos que com base na mesma orientação "Elabore um texto apresentando as estratégias utilizadas pelas professoras e como os alunos progrediram em relação à construção do conhecimento", dada na primeira parte da atividade investigativa da prática docente, elaborassem um texto. Com esta atividade pretendia-se que os licenciandos identificassem agora com uma maior amplitude de conhecimentos, as estratégias 
utilizadas pelas professoras no vídeo para a promoção da construção do conhecimento científico dos alunos do Ensino Fundamental.

Elaboração de mapa conceitual sobre argumentação

A última etapa deste bloco consistiu na elaboração por parte dos licenciandos de um mapa conceitual sobre a argumentação em sala de aula (disciplina), com o intuito que fizessem uma síntese e tivessem um desenvolvimento cognitivo sistematizado em relação ao tema. Para a sua construção, cada licenciando recebeu uma cartolina e cartões para escreverem os conceitos e elaborarem o mapa com base na seguinte questão: "Com base nas discussões e leitura dos textos quais são os aspectos fundamentais para se criar um ambiente argumentativo em sala de aula?".

Após a construção do mapa cada licenciando se dirigiu até a frente da sala e explicou aos seus colegas o mapa que havia elaborado. Com esta atividade fechamos o ciclo de estratégias utilizadas para iniciar e/ou ampliar nos licenciandos uma base de conhecimento sobre a argumentação e seu uso em sala de aula.

\subsubsection{Quarto momento: Atividade de regência}

Neste bloco de atividades, os licenciandos elaboraram um projeto de regência, compartilharam com os colegas, a professora e a monitora da disciplina e tiveram a oportunidade de refletir sobre o mesmo, reelaborá-lo e colocá-lo em ação. Aos licenciandos foi sugerido que elaborassem um projeto de regência contendo uma sequência de ensino, em que as atividades a serem desenvolvidas criassem um ambiente propício para que os alunos do Ensino Médio argumentassem, de maneira a colaborar na construção dos conhecimentos científicos, envolvidos na temática do projeto e de outros aspectos possíveis com a argumentação.

Entregamos aos licenciandos um roteiro (Apêndice 4) para que se orientassem na elaboração do projeto de regência. Cada licenciando ficou responsável por uma turma do Ensino Médio e elaborou individualmente sua regência, cujo tema foi determinado pela professora de Química da escola do Ensino Médio (Quadro 11). 
QUADRO 11: RELAÇÃO DOS LICENCIANDOS COM OS RESPECTIVOS TEMAS DE REGÊNCIA E AS SÉRIES A QUEM MINISTRARAM A SEQUÊNCIA DE ENSINO.

\begin{tabular}{|c|c|c|c|}
\hline Licenciandos & Temática & Série & $\begin{array}{c}\text { Quantidade } \\
\text { alunos (média } \\
\text { por aula) } \\
\end{array}$ \\
\hline Marta & $\begin{array}{l}\text { Impactos sociais e ambientais } \\
\text { decorrentes da extração de matérias- } \\
\text { primas na sociedade. }\end{array}$ & $1^{\circ} \mathrm{A}$ & 16 \\
\hline Rose & $\begin{array}{l}\text { Impactos sociais e ambientais } \\
\text { decorrentes da extração de matérias- } \\
\text { primas na sociedade. }\end{array}$ & $1^{\mathrm{o}} \mathrm{B}$ & 17 \\
\hline João & $\begin{array}{l}\text { Impactos sociais e ambientais } \\
\text { decorrentes da extração de matérias- } \\
\text { primas na sociedade. }\end{array}$ & $1^{\mathrm{o}} \mathrm{C}$ & 20 \\
\hline Beatriz & Fenômenos eletroquímicos & $2^{\circ} \mathrm{A}$ & 18 \\
\hline Pedro & Fenômenos eletroquímicos & $2^{\circ} \mathrm{B}$ & 17 \\
\hline Tales & $\begin{array}{l}\text { Ciclos biogeoquímicos } \\
\text { desenvolvimento sustentável }\end{array}$ & $3^{\circ} \mathrm{A}$ & 25 \\
\hline
\end{tabular}

\section{Apresentação do projeto de regência}

Os licenciandos apresentaram seus projetos de regência durante as aulas da disciplina de Prática de Ensino de Química. Com tal atividade pretendíamos possibilitar momentos de discussões e contribuições entre os discentes, a docente e a pesquisadora, de maneira a possibilitar momentos de reflexão e contribuir com as atividades a serem desenvolvidas na regência. Após a apresentação e discussão dos projetos de regência os licenciandos João, Rose, Tales e Beatriz tiveram que refazer seus projetos e reapresentá-los em aula posterior.

\section{Elaboração do relatório da regência}

Após a regência os licenciandos elaboraram um relatório em que deveriam se pautar nas seguintes orientações ou questões:

a) Apresente um resumo do que havia sido programado para a regência.

b) O que foi efetivamente realizado dentro do que foi planejado?

c) Quais os problemas enfrentados?

d) Que adaptações foram necessárias realizar? 
e) Como se deu a participação dos alunos durantes as aulas e a receptividade dos mesmos frente às estratégias utilizadas para promover a argumentação?

f) Quais os resultados obtidos a partir da sua avaliação em relação aos alunos?

g) Você acredita que conseguiu promover a argumentação dos alunos? Justifique.

h) Quais facilidades ou dificuldades você encontrou para desenvolver uma regência com foco na argumentação?

i) Faça uma avaliação crítica a respeito de sua regência.

\subsubsection{Quinto momento: Reflexão sobre a prática docente}

Foram proporcionados aos licenciandos diferentes momentos para que pudessem refletir sobre a sua prática em sala de aula. Estas reflexões tinham como foco a atuação docente dos licenciandos numa perspectiva de promover a argumentação dos alunos do Ensino Médio em aulas de Química.

\section{Reflexão individual e coletiva}

Todas as regências foram filmadas e a gravação entregue aos licenciandos, os quais a assistiram, e com base na orientação a seguir, selecionaram episódios e compartilharam com os demais discentes e a docente e monitora da disciplina. "Selecione no mínimo dois episódios da gravação da sua regência que queira compartilhar com seus colegas. Os episódios podem estar relacionados às ações em que obteve êxito ou dificuldade, em relação às atividades voltadas à promoção da argumentação em sala de aula ou a aula de modo geral. Sua opinião sobre os episódios deverá ser justificada”.

A atividade de compartilhamento ocorreu da seguinte maneira: cada licenciando apresentava os episódios selecionados. Os colegas, em ficha específica (Apêndice 5), anotavam considerações sobre o episódio apresentado. Após esta etapa o licenciando tecia considerações sobre o motivo da escolha do episódio. Com esta atividade pretendia-se que os licenciandos fizessem uma reflexão individual e 
coletiva sobre todo o processo, indo desde a elaboração do projeto, suas perspectivas até os resultados realmente obtidos.

\section{Entrevista com os licenciandos}

Uma entrevista individual foi realizada com cada licenciando, no intuito de obter mais informações sobre a escolha das estratégias por eles elegidas para a promoção da argumentação durante sua regência, de identificar saberes desenvolvidos ou aprimorados pelos mesmos. Além disso, a entrevista pode ser mais um momento de reflexão sobre a prática docente dos licenciandos. Como explicitado em momento anterior a entrevista foi do tipo semiestruturada e seguiu o roteiro (Apêndice 6), o qual foi dividido em nove blocos, que representaram áreas de conhecimento que embora estivessem separadas, na maioria dos casos, apresentaram forte relação. Os blocos foram constituídos das temáticas:

a) Processo de formação no Ensino Superior do licenciando

b) Experiências em relação à argumentação

c) Concepção sobre atividades argumentativas

d) Elaboração da regência

e) Impressão do desenvolvimento da regência

f) Reflexão em relação à regência

g) Saberes docentes elaborados no processo de desenvolvimento e execução da regência

h) Pretensões futuras e

i) Visão geral da prática da disciplina Prática de Ensino.

\subsubsection{Trabalho de campo}

A pesquisa foi desenvolvida durante todo o ano letivo de 2011, sendo que o Conhecimento prévio dos licenciandos sobre Argumentação (Primeiro momento) foi realizado no mês de abril. Em paralelo, os licenciandos deram início às atividades do 
Estágio de Observação (Segundo momento), as quais foram desenvolvidas ao longo do primeiro semestre.

As Atividades sobre Argumentação (Terceiro momento), em que a pesquisadora e a docente responsável pela disciplina desenvolveram ações com o intuito dos licenciados terem contato com aspectos teóricos sobre a argumentação em sala de aula, foram desenvolvidas nos meses de junho e agosto. As mesmas foram realizadas durante as aulas da disciplina de Prática de Ensino de Química.

As Atividades de Regência (Quarto momento) foram realizadas nos meses de setembro e outubro, sendo desenvolvidas em parte nas aulas da disciplina, em que os licenciandos apresentaram e discutiram seus projetos de regência e, em parte em uma escola pública de Educação Básica do Estado de São Paulo. A referida escola funciona no período matutino e vespertino, sendo oferecido o Ensino Fundamental, Médio e Educação Especial.

A instituição em que as atividades de estágio foram desenvolvidas localiza-se no centro da cidade, cuja população local tem alto poder aquisitivo. Esta condição leva que os moradores em idade escolar, em sua maioria, frequentem instituições escolares de caráter particular. Devido a esta realidade a escola atende alunos de diferentes locais da cidade, principalmente da periferia.

As atividades que envolvia a Reflexão da prática docente (Quinto momento) foram realizadas em diferentes ambientes, sendo no contexto fora da disciplina de Prática de Ensino de Química, já que os licenciandos elaboraram relatórios nas aulas da própria disciplina e no ambiente universitário, já que a entrevista foi elaborada em horário contrário a aula.

\subsubsection{Análise de Conteúdo}

Utilizamos como metodologia de análise dos dados a Análise de Conteúdo (AC) a qual possibilita descrever e interpretar o conteúdo de diferentes tipos de documentos, usando descrições sistemáticas, qualitativas ou quantitativas, de maneira a reinterpretar as mensagens e a atingir uma compreensão de seus significados que vai além de uma leitura comum (MORAES, 1999). 
De acordo com Moraes (1999), os valores e a linguagem natural do entrevistado e do pesquisador, bem como a linguagem cultural e os seus significados, exercem uma influência sobre os dados da qual o pesquisador não pode fugir. De certo modo a Análise de Conteúdo, é uma interpretação pessoal por parte do pesquisador com relação à percepção que tem do material. Não é possível uma leitura neutra, já que toda leitura se constitui numa interpretação.

A matéria-prima da $\mathrm{AC}$ pode constituir-se de qualquer material oriundo de comunicação verbal ou não-verbal, como cartas, cartazes, jornais, revistas, informes, livros, relatos autobiográfico, discos, gravações, entrevistas, diários pessoais, filmes, fotografias, vídeos etc. Porém tais dados precisam ser processados de maneira a facilitar o trabalho de compreensão, interpretação e inferência a que aspira a análise de conteúdo.

É importante considerar na análise dos textos, o contexto, o conteúdo explícito, o autor, o destinatário e as formas de codificação e transmissão da mensagem. Em relação ao contexto, este deve ser explicitado, porém deve-se considerar que não existem limites lógicos para delimitar o contexto da análise, aspecto que dependerá do pesquisador, da disciplina e dos objetivos propostos para a investigação, além da natureza dos materiais em análise.

Moraes (1999) apresenta cinco etapas para nortear a análise de conteúdo, as quais focalizam em especial uma análise qualitativa, podendo também ser empregados em estudos quantitativos. As categorias são: 1) Preparação das informações; 2) Unitarização ou transformação do conteúdo em unidades; 3) Categorização ou classificação das unidades em categorias; 4) Descrição e 5) Interpretação.

O processo de Preparação das informações consiste em duas etapas, na primeira se identifica os materiais que serão analisados, os quais irão contemplar os objetivos da pesquisa. Na segunda etapa, inicia-se o processo de codificação dos materiais, em que se estabelece um código que possibilite identificar rapidamente cada elemento da amostra de depoimentos ou documentos a serem analisados. Este código poderá ser constituído de números ou letras que a partir deste momento 
orientarão o pesquisador para retornar a um documento específico quando assim o desejar.

No processo de Unitarização se faz diversas leituras dos materiais com a finalidade de definir a unidade de análise ("unidade de registro" ou "unidade de significado"). Para Moraes (1999), a unidade é o elemento unitário de conteúdo a ser submetido posteriormente à classificação e podem ser palavras, frases, temas ou mesmo os documentos em sua forma integral, sendo determinado pela natureza do problema, dos objetivos da pesquisa e do tipo de materiais a serem analisados.

É importante que cada unidade de análise seja isolada de maneira a serem reescritas ou reelaboradas, de modo que possam ser compreendidas fora do contexto original em que se encontravam e que possam ser interpretadas sem auxílio de nenhuma informação adicional. A terceira categoria está relacionada à categorização das unidades de análise, as quais devem ser agrupadas considerando a parte comum entre elas, segundo critérios previamente estabelecidos ou definidos no processo. Estes critérios podem ser semânticos, originando categorias temáticas, sintáticos definindo-se categorias a partir de verbos, adjetivos, substantivos etc, ou pode se utilizar critérios com ênfase nas palavras e seus sentidos ou podem ser fundadas em critérios expressivos focalizando em problemas de linguagem.

As categorias devem ser válidas, exaustivas e homogênea. Entende-se por válida que seja adequada aos objetivos da análise, à natureza do material que está sendo analisado e às questões que se pretende responder por meio da pesquisa. As categorias podem ser definidas a priori em que a validade ou pertinência pode ser construída a partir de um fundamento teórico ou podem emergir dos dados em que os argumentos de validade são construídos gradativamente. A exaustividade deve ser considerada na formação das categorias de maneira que estas possibilitem a inclusão de todas as unidades de análise, não ficando nenhum dado significativo que não possa ser classificado. A homogeneidade das categorias indica que a mesma foi criada em um único princípio ou critério de classificação, baseando-se em uma única variável. Moraes (1999) destaca que tal homogeneidade não deve ser garantida apenas em conteúdo, mas igualmente em nível de abstração.

Além dos aspectos acima mencionados é fundamental que as categorias sejam exclusivas, ou seja, um mesmo dado não pode ser incluído em mais de uma 
categoria, e que atendam ao critério de objetividade. Tal critério está relacionado que não deve haver nenhuma dúvida quanto às categorias em que cada unidade de conteúdo deveria ser integrada. Assim, seria possível que diferentes pesquisadores cheguem a resultados semelhantes quando categorizando as mesmas unidades de conteúdo, a partir das mesmas regras de classificação.

A penúltima etapa do processo de análise é a descrição das categorias identificadas. Moraes (1999) destaca que quando se tratar de uma pesquisa numa abordagem quantitativa esta descrição envolve a organização de tabelas e quadros, apresentando não só as categorias construídas no trabalho, como também computando frequências e percentuais referentes às mesmas. Quando tiver um cunho qualitativo a descrição será geralmente de outra ordem, em que para cada uma das categorias será produzido um texto síntese em que se expresse o conjunto de significados presentes nas diversas unidades de análise incluídas em cada uma delas. Geralmente é recomendável que se faça uso intensivo de "citações diretas" dos dados originais.

A última etapa é a interpretação em que se procura compreender as categorias. Tal análise pode ocorrer com base em uma fundamentação teórica claramente explicitada a priori, em que se explora os significados expressos nas categorias da análise com a teoria, ou pode ocorrer de uma teoria ser construída com base nos dados e nas categorias da análise. 


\section{RESULTADOS}

Inicialmente iremos apresentar de forma conjunta o conhecimento prévio dos licenciandos sobre argumentação e as atividades realizadas pelos mesmos para a aquisição de uma base de conhecimento sobre a temática envolvida. Em seguida, para cada licenciando participante da dinâmica de formação dividimos os resultados em duas partes, em que serão apresentados os aspectos do Estágio de Observação e o Processo de Elaboração, Realização e Reflexão da regência.

\subsection{Construção das categorias de análise}

Para a análise dos dados os dividimos em duas partes: na primeira, iremos analisar e discutir o conhecimento prévio dos licenciandos sobre a argumentação e seu papel no processo de ensino e aprendizagem ocorrido em sala de aula. $\mathrm{Na}$ segunda parte, analisaremos as atividades desenvolvidas pelos licenciandos relacionadas à promoção da argumentação em sala de aula de Química do Ensino Médio.

As categorias sobre o conhecimento prévio dos licenciandos sobre a argumentação foram criadas após a leitura minuciosa das respostas a cada questão do questionário. Fizemos inicialmente a impressão de cada resposta e montamos fichas em que cada uma correspondia a uma resposta distinta. Para a categorização, agrupamos todas as fichas referentes a cada questão, em seguida fizemos a transformação de seus conteúdos em unidades, ou seja, em termos em que cada uma 
expressava um conceito, usando as expressões originais dos licenciandos. Uma vez identificadas as unidades, as agrupamos de acordo com sua similaridade.

Em seguida fizemos uma categorização usando termos que abarcavam as ideias com proximidade dos licenciandos, de maneira que as categorias fossem excludentes. Buscamos depois agrupar cada unidade a categoria nomeada, de maneira a termos a frequência em que cada categoria foi identificada nas respostas.

$\mathrm{Na}$ segunda parte analisamos as atividades desenvolvidas pelos licenciandos as quais estavam relacionadas à promoção da argumentação em sala de aula de Química do Ensino Médio. No que concerne a analise dos saberes desenvolvidos e/ou aprimorados pelos licenciandos em relação às atividades argumentativas realizadas em sala de aula e ao longo da disciplina da PEQ, criamos as categorias com base em trabalhos da literatura (Quadro 12) e nos resultados das ações dos licenciandos, ou seja, com base em dados empíricos.

Buscamos uma nomenclatura própria para os saberes identificados nesta etapa do projeto, que designamos como Saber de Argumentação Docente (SAD). A ideia da categorização é expressar os saberes gerais da prática docente essenciais para a promoção da argumentação em sala de aula. Assim, cada saber é denominado pela referida nomenclatura, a qual assume um núcleo comum, acrescida da denominação que a específica. Por exemplo, para o saber que relacionamos ao conhecimento do docente quanto aos conteúdos a serem ensinados em sala de aula, denominamos de Saber de Argumentação Docente Disciplinar.

Definimos seis saberes principais (Quadro 12), a saber:

1. Saber de Argumentação Docente Disciplinar

2. Saber de Argumentação Docente dos Fins Educacionais

3. Saber de Argumentação Docente de Reflexão

4. Saber de Argumentação Docente Sociocientífico

5. Saber de Argumentação Docente Relativo às Estratégias

6. Saber de Argumentação Docente da Aprendizagem Compartilhada. 
Além disso, caracterizamos cinco saberes decorrentes diretamente do SAD Relativo às Estratégias, a saber:

- SAD de Gerenciar Ideias promovendo Justificação

- SAD Promover Feedback

- SAD de Conhecer os Elementos do Argumento

- SAD de Gerenciar ideias Instigando Questionamentos

- SAD da Análise do Argumento

O Saber de Argumentação Docente Disciplinar representa o conhecimento do professor sobre o conteúdo a ser ensinado. O trabalho de Costa (2008) apresenta que para argumentar é necessário que os alunos tenham conhecimento sobre o assunto abordado para que possam explicar e justificar suas hipóteses com fundamento e se sentirem mais capazes de argumentar. Diante destas ideias fazemos uma extrapolação e consideramos que saber o conteúdo não se limita ao aluno, mas se estende ao professor, já que para desenvolver atividades em sala de aula o conhecimento é parte essencial para a promoção da argumentação.

Encontramos também apoio nos trabalhos de Tardif (2010), que considera o Saber Disciplinar como o relativo aos diferentes campos do conhecimento como Ciências Exatas, Humanas e Biológicas, e os quais são abordados nas disciplinas escolares ao longo dos diferentes níveis de ensino. No caso deste trabalho, os conteúdos referentes às Ciências Exatas estão voltados ao Ensino de Química e de Ciências.

Como já mencionamos consideramos que há uma relação direta do SAD Disciplinar com os demais SADs, pois, o conhecimento do conteúdo a nosso ver é um dos pilares para que o professor possa gerenciar as ideias dos alunos e as suas próprias. Isto decorre do fato que o professor precisa conhecer sobre o assunto para instigar questionamentos, fornecer e/ou suscitar justificações aos argumentos apresentados, de fornecer um feedback aos alunos quanto à validade de suas colocações e de conseguir reconhecer o argumento com base em uma perspectiva, por exemplo, do modelo de Toulmin. Ademais, o conhecimento sobre o conteúdo também possibilita ao professor sentir-se com mais segurança para escolher a estratégia que melhor se adequa ao nível de complexidade do assunto abordado, e que possa refletir, dentre outros aspectos, o quanto os alunos aprenderam. 
No Saber de Argumentação Docente dos Fins Educacionais, o professor busca na literatura ou em sua própria prática subsídios para dar a conotação da atividade argumentativa. Com este saber, o professor pode desenvolver e/ou aprimorar seu conhecimento no que tange à escolha e ao desenvolvimento da estratégia argumentativa, e de sua análise. Assim, o SAD dos Fins Educacionais dá apoio também para que o professor analise e reflita sobre sua ação.

Encontramos no trabalho de Perez, Bebechi, Azevedo, Schreiner, Mattia, Slowik e Oliveira (2011) subsídios que fortalecem a necessidade do SAD dos Fins Educacionais. Os autores analisaram a consistência dos argumentos de alunos do Ensino Superior e concluíram que o professor deve trabalhar com textos de natureza científica, de maneira a direcionar a busca dos alunos por informações visando não só a construção de argumentos mais consistentes, mas também a facilitação no uso de diferentes tipos de argumentos como retóricos, dialógicos, racionais e persuasivos. Tal resultado vem corroborar a necessidade do professor ter conhecimento teórico sobre aspectos da argumentação para promover um ambiente argumentativo.

No Saber de Argumentação Docente Relativo às Estratégias, o professor, com base nos conhecimentos teóricos e práticos, desenvolve, seleciona e utiliza estratégias que potencialmente possibilitam um ambiente argumentativo. Aufschnaiter, Erduran, Osborne e Simon (2008) concebem que a frequência em que a argumentação ocorre em sala de aula está fortemente atrelada ao tipo de tarefa que desenvolvem. De acordo com os autores, quanto mais complexa a tarefa, mais elementos do conteúdo precisam ser considerados, o que requer um maior nível de abstração. Tal asserção implica na necessidade do professor utilizar estratégias mais significativas ao desenvolvimento cognitivo dos alunos, o que potencializa a importância deste saber ao docente na promoção de ambientes argumentativo em sala de aula.

Consideramos que quando o professor desenvolve o SAD Relativo às Estratégias ele consegue trabalhar em sala de aula com posicionamentos divergentes entre os alunos, seja por meio do diálogo ou por outras atividades. Além disso, pode promover articulação, sistematização e gerenciamento de suas ideias e a dos seus alunos tentando também incentivar os alunos a questionarem outras afirmações dos 
colegas e do próprio professor, o que significa a gerar o SAD de Gerenciar Ideias Instigando Questionamentos; o SAD de Promover a Justificação; o SAD de Conhecer os Elementos do Argumento e o SAD de Promover Feedback.

$\mathrm{Na}$ busca de darmos sustentação aos SADs Relativo às Estratégias apresentamos referenciais teóricos que embasam a necessidade do gerenciamento de ideias em sala de aula. Santos, Mortimer e Scott (2001) consideram que no processo de argumentação o diálogo tem um papel fundamental, já que em situações desta natureza os alunos precisam expressar e justificar seu ponto de vista. Tais elementos nos remetem à necessidade do professor saber atuar como um suscitador e mediador da dinâmica discursiva.

Brown (2007) considera que os professores podem contribuir para que ocorra argumentação coletiva em sala de aula. Em busca deste resultado é necessário que haja uma negociação de valores entre os sujeitos do processo, os quais envolveriam a expressão de aspectos como virtude, honestidade, moderação das ideias dos sujeitos, a representação, a comparação, explicação, justificação, concordância e validação de palavras-chave, guias de atividades e participação colaborativa em sala de aula.

Em um contexto de pequenos grupos o professor ouve os alunos, observa as atividades, incorporando desafios no que tange à participação destes e na demonstração das diferentes representações, explicações e justificativas dos alunos. Essa ação docente pode ocorrer por meio de perguntas sobre as representações dos alunos, incorporando novos elementos, identificando similaridades e diferenças nas representações, em que são suscitadas representações pessoais, possibilitando o surgimento de explicações e justificativas ao objeto de estudo.

Vieira e Nascimento (2009) apresentam em seu trabalho o que denominam de Procedimentos Discursivos Didáticos em que consideram os principais papéis que um professor deve assumir como formador para que ocorra a argumentação em sala de aula. No referido trabalho, os autores consideram estes aspectos no contexto de um curso de licenciatura. No entanto, a nosso ver tais considerações são pertinentes a professores em qualquer âmbito de atuação. Os papéis estão relacionados ao professor como sendo um Avaliador de pontos de vista, Gerenciador de discussões e Auscultador. 
Nascimento, Platin e Vieira (2008), também apontam a necessidade do professor assumir um papel de auscultador, em que adquire uma postura de ouvinte atento às interações discursivas entre os alunos. Tal ação possibilita que em determinados momentos o professor possa tomar posições, que se traduzem em procedimentos que repercutem no discurso argumentativo ou possibilita sua fomentação ou fechamento.

Considerando agora o Saber de Argumentação Docente Sociocientífico consideramos que este é fundamental para a sociedade atual, já que sabemos que os cidadãos devem receber uma formação que possa contemplar as iniciativas de tomadas de decisões em assuntos de caráter de natureza sociocientífico, podendo inclusive avaliar os impactos de suas decisões em suas vidas (RAMOS e RUZ, 2010; DAWSON e VENVILLE, 2010). Os problemas com caráter sociocientífico geralmente, estão próximos da realidade dos estudantes, são abertos, complexos e controversos, o que permite análises com uma variedade de perspectivas.

Considerando estas necessidades, espera-se que o professor saiba inicialmente que existem questões envolvendo a Ciência, a Tecnologia e a Sociedade e o meio ambiente, e que a população pode assumir um papel ativo nas decisões envolvendo estes aspectos. Além disso, torna-se de suma importância que o professor trabalhe a aplicação do conhecimento científico no contexto de tomada de decisões sociocientíficas, os quais, atrelados aos valores dos alunos irão constituir na base para a tomada de decisão (JIMENEZ-ALEIXANDRE, 2005).

A necessidade de envolver o conhecimento escolar com as ações na sociedade está de acordo com as propostas de Jimenez-Aleixandre (2005), e preconizada fortemente por Paulo Freire (1996). Este último quando aponta a ideia de que é preciso ocorrer uma educação problematizadora no sentido de colaborar com o compromisso social. Para a autora, tal abordagem no Ensino de Ciências contribui para a superação de uma imagem de ciência neutra e imparcial, para uma visão que a compreende como uma construção social oriunda de uma atividade humana.

Assim, entendemos que o trabalho com problemas de caráter sociocientífico colaboram com a compreensão da Natureza da Ciência, já que em geral apresentamse numa linha de problemas sociocientíficos. Desta forma, consideramos que o Saber 
de Argumentação Docente Sociocientífico possibilitará ao professor ter conhecimentos e habilidades que possam promover uma contextualização do conhecimento científico com implicações nas tomadas de decisão da sociedade.

Ao sugerirmos o Saber de Argumentação Docente de Reflexão, consideramos que o professor, em diferentes momentos de sua ação (planejamento, implementação e avaliação) reflete sobre ela, a modifica quando necessário, realiza uma análise após sua intervenção, de maneira que esta poderá auxiliar no planejamento de aprimoramento de ações futuras docente.

Tivemos como base para a elaboração do SAD de Reflexão os trabalhos de Schön (2000), Freitas e Vilani (2002), Maldaner (2000) e Sanmamed e Abeledo (2011), os quais apresentam a necessidade do professor refletir sobre sua ação em diferentes momentos, abarcando o seu planejamento, perpassando pelo momento em que a ação ocorre e após sua ocorrência. Destacamos que para o SAD de Reflexão constituir-se como saber, não basta que ocorram reflexões, mas que se formem um conhecimento explícito e consciente de que esses processos são importantes para a melhoria das ações argumentativas, ou seja, é necessário que sejam explicitadas os porquês.

As reflexões por parte do docente (ou futuro professor) possibilitará nas escolhas de melhores metodologias a serem utilizadas em sala de aula. Ajudará numa constante avaliação de sua prática com relação aos seus objetivos de ensino e de aprendizagem dos alunos, com busca de uma melhoria diária em sua ação como docente. Desta forma, se queremos que os docentes desenvolvam atividades argumentativas em sala de aula de forma efetiva é necessário que tenham essa postura de reflexão sobre sua prática e que tenham consciência dessa importância no aprimoramento de suas ações. Identificamos uma relação direta do SAD de Reflexão com o Saber de Argumentação Docente Relativo às Estratégias, já que o desenvolvimento, a escolha e o uso das estratégias requerem do docente uma reflexão, que permeia os diferentes momentos da atividade, desde a sua concepção ao resultado final.

Ainda num contexto de reflexão consideramos importante que o professor desenvolva o Saber de Argumentação Docente da Aprendizagem Compartilhada. 
Este saber torna-se importante, pois é fundamental que os professores se envolvam coletivamente em um movimento reflexivo, de maneira a perceberem a importância e benefícios em compartilharem suas ações docentes com seus pares e tenham também consciência do seu papel em seu desenvolvimento. Este momento de compartilhamento é importante, pois o compartilhamento com os pares possibilita aos sujeitos expressarem suas ideias e desenvolver conhecimento (EVAGOROU e OSBORNE, 2013).

De acordo com Langhi e Nardi (2011) é importante que os professores de maneira conjunta identifiquem e reflitam sobre os problemas e maneiras de solucioná-los, que pensem e desenvolvam ações que visem melhorar o processo de ensino e aprendizagem e analisem suas práticas docentes. Além disso, nos diferentes momentos do processo de prática docente tanto nos que envolvem seus pares, como os que envolvem os alunos é possível ao professor aprender de forma colaborativa. Também encontramos no trabalho de Zeichner (1993) subsídios da importância dos professores desenvolverem ações de forma compartilhada. 
QUADRO 12: CATEGORIAS DOS SABERES DE ARGUMENTAÇÃO DOCENTE RELATIVOS AO DESENVOLVIMENTO DE ATIVIDADES ARGUMENTATIVAS EM SALA DE AULA.

\begin{tabular}{|c|c|c|}
\hline Categorias & Definição dos saberes & Referencias teóricos \\
\hline $\begin{array}{l}\text { Saber de Argumentação Docente } \\
\text { Relativo às Estratégias }\end{array}$ & $\begin{array}{l}\text { O professor com base nos conhecimentos teóricos e práticos, desenvolve, seleciona e utiliza } \\
\text { estratégias que potencialmente possibilitam um ambiente argumentativo. Nas atividades o } \\
\text { professor identifica e trabalha com posicionamentos divergentes entre os alunos, seja por meio } \\
\text { do diálogo ou por uma atividade, promove articulação, sistematização e gerenciamento de ideias. }\end{array}$ & $\begin{array}{l}\text { Aufschnaiter, Erduran, Osborne e } \\
\text { Simon (2008) }\end{array}$ \\
\hline SAD Análise dos argumentos & $\begin{array}{l}\text { O professor analisa os argumentos suscitados em sala de aula, em que considera fortemente os } \\
\text { modelos de argumentação. }\end{array}$ & Tardif $(2010)$ \\
\hline $\begin{array}{l}\text { SAD de Gerenciar Ideias promovendo } \\
\text { Justificação }\end{array}$ & $\begin{array}{l}\text { O professor justifica suas colocações e/ou cria um ambiente para que alunos justifiquem suas } \\
\text { ideias e apresentem contra-argumentos. }\end{array}$ & \multirow{4}{*}{$\begin{array}{l}\text { Schön (2000); Santos, Mortimer e } \\
\text { Scott (2001); Brown (2007); Vieira } \\
\text { e Nascimento (2009) }\end{array}$} \\
\hline SAD Promovendo Feedback & O professor analisa o posicionamento do aluno e dá retorno quanto a sua validade e pertinência. & \\
\hline $\begin{array}{l}\text { SAD de Conhecer os Elementos do } \\
\text { Argumento }\end{array}$ & O professor tem conhecimento sobre os elementos teóricos que constituem um argumento. & \\
\hline $\begin{array}{l}\text { SAD de Gerenciar Ideias Instigando } \\
\text { Questionamentos }\end{array}$ & $\begin{array}{l}\text { O professor questiona os alunos e faz com que estes se questionem e também o questionem, } \\
\text { gerando discussões. }\end{array}$ & \\
\hline $\begin{array}{l}\text { Saber de Argumentação dos Fins } \\
\text { Educacionais }\end{array}$ & $\begin{array}{l}\text { O professor busca na literatura ou em sua própria prática subsídios para dar a conotação da } \\
\text { atividade argumentativa, ou seja, tem conhecimento sobre os aspectos teóricos da argumentação } \\
\text { e os utiliza no processo de ensino-aprendizagem. }\end{array}$ & $\begin{array}{l}\text { Tardif (2010); Perez, Bebechi, } \\
\text { Azevedo, Schreiner, Mattia, Slowik } \\
\text { e Oliveira (2011) }\end{array}$ \\
\hline $\begin{array}{l}\text { Saber de Argumentação Docente } \\
\text { Disciplinar }\end{array}$ & $\begin{array}{l}\text { O professor utiliza os conhecimentos das ciências de referência e os emprega no } \\
\text { desenvolvimento de aula em uma perspectiva argumentativa. }\end{array}$ & Costa (2008), Tardif (2010) \\
\hline $\begin{array}{l}\text { Saber de Argumentação Docente } \\
\text { de Reflexão }\end{array}$ & $\begin{array}{l}\text { O professor reflete sobre sua ação considerando aspectos do processo de ensino e } \\
\text { aprendizagem, é fundamental que o professor além de refletir explicite e tenha consciência que } \\
\text { esses processos são importantes para a melhoria das ações argumentativas. }\end{array}$ & $\begin{array}{l}\text { Schön (2000); Maldaner (2000); } \\
\text { Freitas e Vilani (2002) e Sanmamed } \\
\text { e Abeledo (2011), }\end{array}$ \\
\hline $\begin{array}{l}\text { Saber de Argumentação Docente } \\
\text { Sociocientífico }\end{array}$ & $\begin{array}{l}0 \text { professor desenvolve atividades argumentativas que envolvem conhecimento científico de } \\
\text { caráter sociocientífico. }\end{array}$ & $\begin{array}{l}\text { Jimenez-Aleixandre (2005); Ramos, } \\
\text { Ruz, (2010); Dawson, Venville, } \\
\text { (2010); Evagorou e Osborne (2013) }\end{array}$ \\
\hline $\begin{array}{l}\text { Saber de Argumentação Docente } \\
\text { da Aprendizagem Compartilhada }\end{array}$ & $\begin{array}{l}\text { O professor se envolve coletivamente em um movimento reflexivo, de maneira a perceber a } \\
\text { importância e benefícios em compartilharem suas ações docentes com seus pares e tem } \\
\text { consciência do seu papel em seu desenvolvimento. }\end{array}$ & $\begin{array}{l}\text { Langhi e Nardi (2011), Zeichner } \\
\text { (1993); Evagorou e Osborne (2013) }\end{array}$ \\
\hline
\end{tabular}


Apresentamos (Figura 2) as relações existentes entre os diferentes Saberes de Argumentação Docente identificados nesta pesquisa. Como podemos observar o SAD está no centro do esquema e dele derivam os demais saberes. Consideramos que este saber fundamenta os demais no que concerne ao fato de que uma vez tendo domínio do conhecimento, o professor pode se sentir mais apto a trabalhar com diferentes estratégias de ensino, de realizar análise do processo de aprendizagem dos alunos, de promover o gerenciamento das ideias dos alunos e de suas próprias e de refletir sobre suas ações com seus colegas.

O SAD dos Fins Educacionais dá um embasamento para o SAD de Reflexão já que uma vez conhecendo o que se pretende de habilidades argumentativas dos alunos, é possível refletir se foi possível ou não desenvolver um ambiente numa perspectiva argumentativa. Este saber também colabora com o SAD relativo às Estratégias, pois colabora para que o professor escolha estratégias mais adequadas a suscitação da argumentação em sala de aula e também para o desenvolvimento de trabalhos numa perspectiva sociocientífica.

O SAD de Aprendizagem Compartilhada colabora com o SAD de Reflexão, já que ao compartilhar suas experiências os professores refletem sobre diferentes aspectos do seu processo de prática docente, o que contribui com sua aprendizagem. Além disso, este último saber possui uma forte relação com o SAD Relativo às Estratégias, pois devido a reflexões o professor escolhe as estratégias visando a ambientes argumentativos, e da mesma forma após as ações, os professores podem voltar a refletirem de maneira que venham a considerar os prós e contras da estratégia escolhida. 


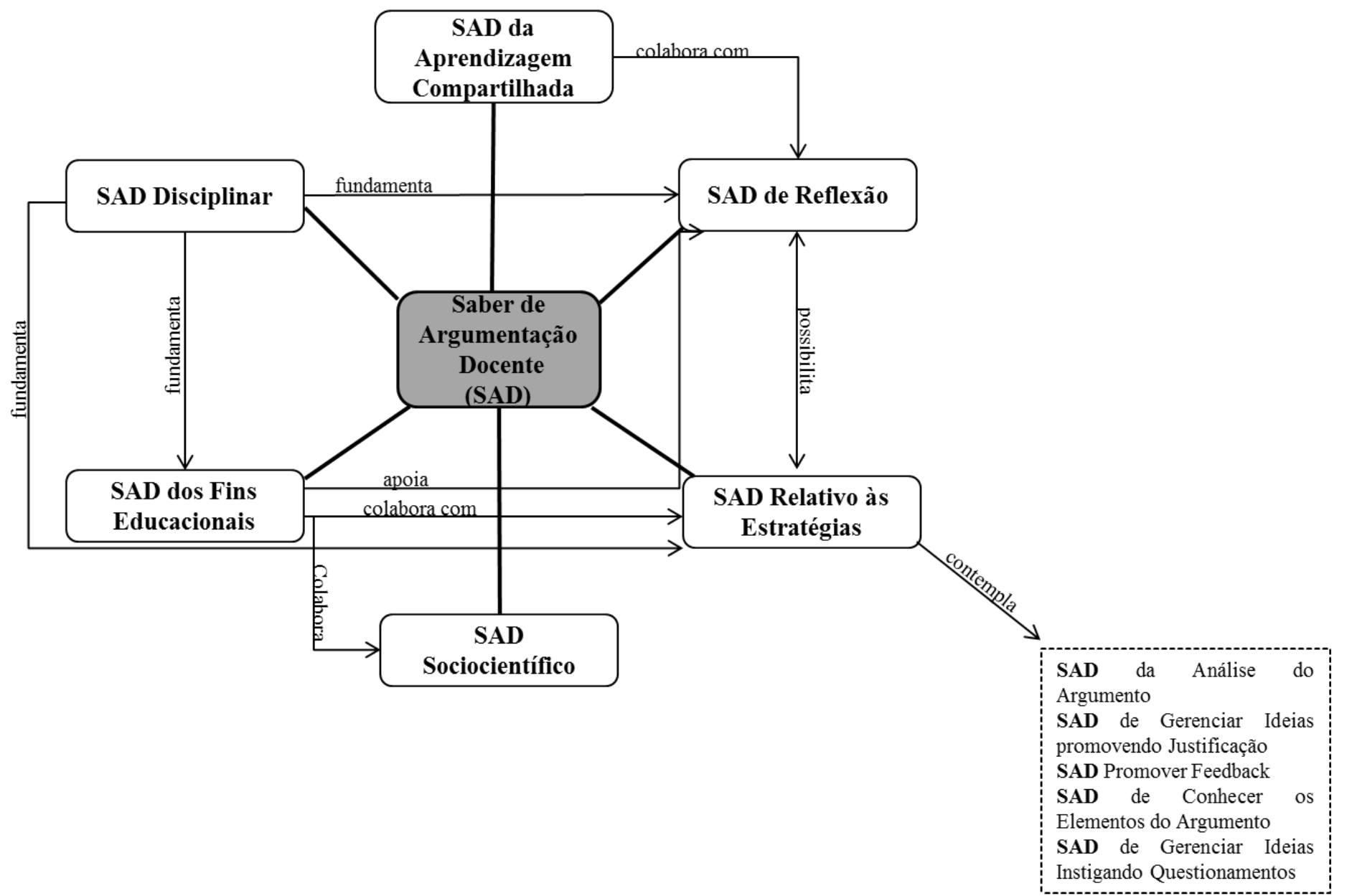

FIGURA 2: ESQUEMA SOBRE OS SABERES DE ARGUMENTAÇÃO DOCENTE UTILIZADOS NA CATEGORIZAÇÃO DOS SABERES DOS LICENCIANDOS. 
Numa busca de identificarmos como os SADs podem colaborar com a suscitação dos elementos de um argumento, fizemos um movimento (Figura 3) em que para cada saber buscamos a relação com os elementos do modelo de Toulmin (Figura 1). Identificamos que o Saber de Argumentação Docente Disciplinar é fundamental para que sejam fornecidos os dados, os quais servem de base à resolução de um problema ou a comprovação de um enunciado. Nesta mesma linha o SAD Sociocientífico pode possibilitar que o professor apresente o problema a ser discutido, o que tem relação direta com os dados.

Além disso, a estratégia (SAD Relativo às Estratégias) influencia também no elemento (dado), pois a partir dela o aluno tem acesso à informação. De igual importância destacamos o gerenciamento das ideias dos sujeitos envolvidos no processo, pois irá conduzir a cognição do aluno numa busca de entender os Dados e a reflexão do docente nos diferentes momentos da atividade. Além disso, conhecer a finalidade da atividade argumentativa (SAD dos Fins Educacionais) possibilitará uma melhor escolha para o fornecimento dos dados aos alunos.

No que concerne à justificativa, ao conhecimento básico, a refutação e ao qualificador modal entendemos que o conteúdo (SAD Disciplinar) torna-se fundamental, pois sem ter conhecimento sobre o assunto abordado tanto aluno como professor, promovem uma discussão em um nível de suposição. As estratégias (SAD Relativo às Estratégias) e seus saberes atrelados, e a reflexão docente (SAD Reflexão) também representam um papel importante, pois são elas que darão a possibilidade de se criar um ambiente numa perspectiva argumentativa.

No que concerne ao SAD Sociocientífico podemos inferir que este colabora com informações que servem de base à justificativa e ao conhecimento básico, presentes no argumento. Além disso, pode fornecer as diferentes consequências relacionadas às conclusões. $\mathrm{O}$ SAD dos Fins Educacionais possibilitará um direcionamento mais significativo da atividade proporcionando um ambiente favorável ao desenvolvimento desses elementos. Consideramos que o SAD de Aprendizagem Compartilhada permeia a suscitação de todos os elementos do argumento, pois a cada diálogo entre os envolvidos no processo argumentativo é possível que se aprenda. 


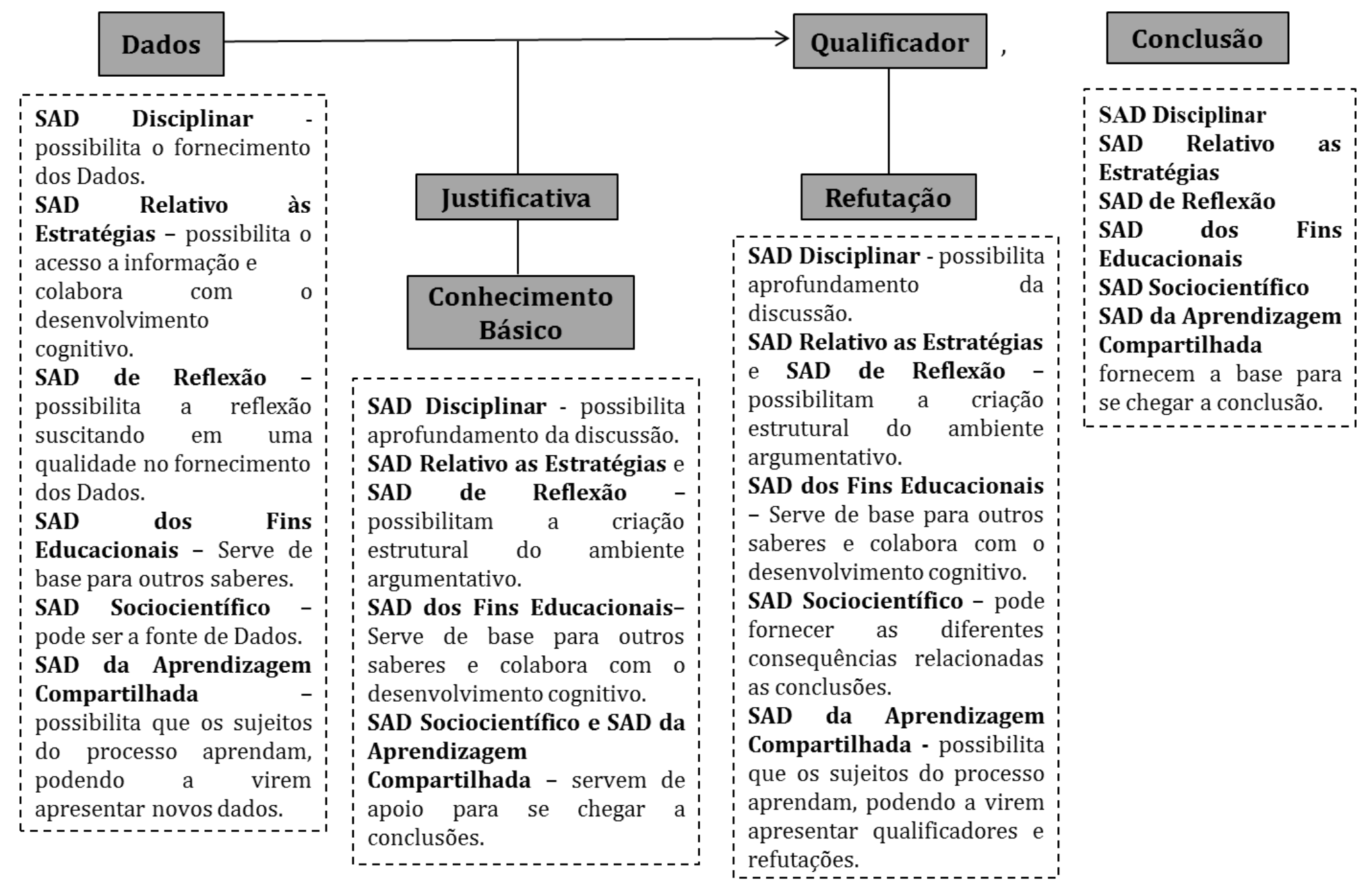

FIGURA 3: ESQUEMA QUE REPRESENTA RELAÇõES ENTRES SABERES DE ARGUMENTAÇÃO DOCENTES E O MODELO DE TOULMIN (2001). 


\subsection{Concepções prévias dos licenciandos sobre argumentação}

Para os licenciandos argumentação é "o ato de expressar ideias, opiniões a um público com a intenção de convencê-lo", conforme ilustrado no Quadro 13 e grifado nas transcrições abaixo (grifos nossos ${ }^{6}$ ). Dos licenciandos, três, Pedro, Rose e Tales, destacam que além de usar argumentos é necessário qualificá-los usando informações, conhecimentos e bases confiáveis para defendê-los.

Argumentação é o uso de conhecimentos vários para defender um tópico de modo convincente, porém nem sempre o lado mais correto (no momento) ${ }^{7}$ sai vencedor, pois a capacidade de argumentação é realmente o ponto-chave. [MARTA], (Fonte: Questionário)

Argumentação ocorre quando duas ou mais pessoas apresentam suas opiniões sobre determinado assunto e as defendem com argumentos favoráveis ou não ao seu ponto de vista. [JOÃO], (Fonte: Questionário)

\begin{tabular}{|c|c|c|}
\hline \multicolumn{2}{|c|}{ Categoria } & \multirow{2}{*}{$\begin{array}{l}\text { Licenciandos } \\
\text { Beatriz, João e } \\
\text { Marta }\end{array}$} \\
\hline $\begin{array}{l}\text { Argumentação é o ato de } \\
\text { expressar ideias, opiniões }\end{array}$ & & \\
\hline $\begin{array}{l}\text { a um público com a } \\
\text { intenção de convencê-lo. }\end{array}$ & $\begin{array}{l}\text { Usando informações e } \\
\text { bases } \\
\text { promovendo ronfiáveis } \\
\text { argumentação qualificada. }\end{array}$ & $\begin{array}{l}\text { Pedro, Rose e } \\
\text { Tales }\end{array}$ \\
\hline
\end{tabular}

Para os licenciandos o processo argumentativo pode apresentar duas conotações, uma em que alunos, argumentam para demonstrar o conhecimento que possuem e outras em que a argumentação tem, para os professores, um papel de transmissão do conhecimento.

Penso no termo "argumentação" em dois âmbitos. No primeiro como aluno em que para afirmar o conhecimento aprendido utiliza-se de argumentos que justifiquem o domínio de conhecimento. No outro âmbito o professor utiliza a argumentação como instrumento didático na transmissão do conhecimento. [TALES], (Fonte: Questionário)

\footnotetext{
${ }^{6}$ Nesta seção de resultados sobre as concepções dos licenciandos sobre argumentação sublinharemos algumas colocações dos futuros professores com o intuito de destacá-las dentro do contexto.

${ }^{7}$ Sempre que necessário escreveremos entre parenteses observações que possam colaborar na compreensão do leitor sobre os apontamentos dos licenciandos em sua fala.
} 
Num contexto em que os licenciandos se posicionam como alunos em um processo de argumentação, três dos seis licenciandos (Quadro 14) apresentam que argumentam enquanto alunos. Nesta situação o fazem quando precisam comprovar a aprendizagem, em uma conotação retórica. Tales e Beatriz colocam que argumentam quando se posicionam a favor ou contra um determinado assunto. Já João é categórico em dizer que, como aluno, nunca teve um espaço para argumentar em sala de aula.

\section{QUADRO 14: CATEGORIAS OBTIDAS PARA SITUAÇÕES ARGUMENTATIVAS QUE OS LICENCIANDOS VIVENCIAM COMO ALUNO.}

\begin{tabular}{l|l}
\hline \hline \multicolumn{1}{c|}{ Categorias } & Licenciandos \\
\hline \hline $\begin{array}{l}\text { Argumentação para averiguar } \\
\text { conhecimentos aprendidos }\end{array}$ & $\begin{array}{l}\text { Rose, Marta e } \\
\text { Pedro }\end{array}$ \\
\hline Espaço de discussão: prós e contras & $\begin{array}{l}\text { Tales } \\
\text { Beatriz }\end{array}$ \\
\hline $\begin{array}{l}\text { Não teve espaço para argumentação } \\
\text { em sala de aula }\end{array}$ & João \\
\hline
\end{tabular}

Observa-se que ainda no papel de quem argumenta os licenciandos apresentam que, para isto, necessitam se preparar, de uma maneira formal, a qual the proporcionará a segurança no processo de argumentação (Quadro 15). Porém, mesmo com preparação há licenciandos que dizem ficarem nervosos, conforme trecho a seguir.

Nervoso, principalmente se não estou preparado para argumentar. Se me preparo, o nervosismo é menor. [TALES], (Fonte: Questionário)

QUADRO 15: CATEGORIAS OBTIDAS PARA COMO OS LICENCIANDOS SE SENTEM A ARGUMENTAREM EM PÚBLICO.

\begin{tabular}{l|l}
\hline \multicolumn{1}{c|}{ Categorias } & \multicolumn{1}{c}{ Licenciandos } \\
\hline \hline $\begin{array}{l}\text { Tranquilo e confiante com } \\
\text { preparo adequado }\end{array}$ & João, Rose e Pedro \\
\hline Inseguro e nervoso & $\begin{array}{l}\text { Tales, Beatriz e } \\
\text { Marta }\end{array}$ \\
\hline
\end{tabular}

Em relação à promoção da argumentação em sala de aula os seis licenciandos se posicionaram favoráveis, sendo em alguns casos expressando sua opinião usando 
adjetivos superlativos, conforme transcrições abaixo (grifos nossos). Os licenciandos apresentam como justificativa sobre o porquê trabalhar a argumentação em sala de aula aspectos relacionados ao auxílio no processo de aprendizagem dos conceitos, na formação do cidadão crítico e na identificação das dificuldades e conhecimento prévio dos alunos, conforme observado no (Quadro 16).

Ótima ideia, pois ela desenvolve muitas habilidades, entre elas o uso da linguagem, pesquisa e análise de referências. [MARTA], (Fonte: Questionário)

Uma boa ideia, porém é preciso passar a eles boas instruções de como fazer, para que sejam argumentos convincentes e não apenas suposições. [ROSE], (Fonte: Questionário)

Acho que ajudaria no desenvolvimento do aluno, pois para ele argumentar ele precisa saber o conteúdo (caso ele não sabia, ele deve procurar aprender) $e$ procurar melhor forma de expor suas ideias, ao expor suas ideias e conhecimento é trabalhado sua forma de expressão (no caso o aluno busca uma melhor forma de transmitir seu conhecimento e suas ideias. [BEATRIZ], (Fonte: Questionário)

QUADRO 16: JUSTIFICATIVA DA IMPORTÂNCIA EM SE TRABALHAR A ARGUMENTAÇÃO EM SALA DE AULA.

\begin{tabular}{l|c}
\hline \multicolumn{1}{c|}{ Categorias } & Licenciandos \\
\hline \hline $\begin{array}{l}\text { Auxilia no processo de } \\
\text { aprendizagem dos conceitos }\end{array}$ & Tales e Beatriz \\
\hline $\begin{array}{l}\text { Auxilia na formação do cidadão } \\
\text { crítico }\end{array}$ & João e Pedro \\
$\begin{array}{l}\text { Desenvolve habilidades de } \\
\text { expressão }\end{array}$ & Beatriz e Marta \\
$\begin{array}{l}\text { Auxilia a identificar as dificuldades } \\
\text { dos alunos }\end{array}$ & João \\
$\begin{array}{l}\text { Identifica conceitos prévios dos } \\
\text { alunos }\end{array}$ & Tales \\
\hline
\end{tabular}

Em relação às estratégias que facilitam ou dificultam a argumentação em sala de aula, os licenciandos mencionaram (Quadro 17), como facilitadoras: atividades em que o aluno participa ativamente do processo de ensino, o uso de métodos investigativos e leitura de textos com discussão em sala de aula. As estratégias que não favorecem são aulas expositivas sem diálogos e o ensino centrado no professor.

Além das estratégias, também foram mencionados aspectos que não favorecem a argumentação relacionados diretamente aos professores, sendo: 
dificuldade do docente em mediar o processo, o medo do aluno em falar em público e sua falta de interesse na aprendizagem.

QUADRO 17: ESTRATÉGIAS E ASPECTOS NA VISÃO DOS LICENCIANDOS QUE FACILITAM OU DIFICULTAM A ARGUMENTAÇÃO EM SALA DE AULA.

\begin{tabular}{|c|c|c|}
\hline \multicolumn{2}{|r|}{ Categorias } & Licenciandos \\
\hline \multirow{3}{*}{$\begin{array}{l}\text { Estratégias } \\
\text { favorecem } \\
\text { argumentação }\end{array}$} & $\begin{array}{l}\text { Atividades em que o aluno } \\
\text { participa ativamente } \\
\text { processo de ensino } \\
\end{array}$ & João e Tales \\
\hline & Métodos investigativos & Pedro \\
\hline & $\begin{array}{l}\text { Leitura de textos com discussão } \\
\text { em sala de aula }\end{array}$ & Beatriz \\
\hline \multirow{2}{*}{$\begin{array}{l}\text { Estratégias que } \\
\text { favorecem } \\
\text { argumentação }\end{array}$} & Aulas expositivas sem diálogos & Pedro \\
\hline & Ensino centrado no professor & João e Tales \\
\hline \multirow{3}{*}{$\begin{array}{l}\text { Aspectos que não } \\
\text { favorecem }\end{array}$} & $\begin{array}{l}\text { Medo do aluno em falar em } \\
\text { público }\end{array}$ & Marta \\
\hline & Falta de interesse dos alunos & Beatriz \\
\hline & $\begin{array}{l}\text { Dificuldade do professor em } \\
\text { mediar o processo }\end{array}$ & Marta e Tales \\
\hline
\end{tabular}

As concepções dos licenciandos sobre argumentação destacam-na como uma estratégia importante no processo de ensino-aprendizagem e na formação de um cidadão crítico e como sendo o ato de expressar ideias, opiniões a um público com a intenção de convencê-lo. No entanto, observa-se que estes, quando assumem o papel de sujeitos que praticam a argumentação, a consideram como sendo um evento em que o preparo intensivo é necessário, não deixando a entender que a argumentação pode ocorrer frequentemente em sala de aula.

Em relação às estratégias que favorecem a argumentação foram mencionadas atividades em que há discussão em sala de aula, na qual se desenvolve um método investigativo e a participação ativa dos alunos. É de destaque que poucas foram as estratégias mencionadas, três no total. Outro aspecto destacado pelos licenciandos é a necessidade de se ter um preparo adequado dos professores à promoção de atividades argumentativas, o que na opinião dos questionados não há muitos professores que 
possuem tais habilidades, levando-se a inferir a necessidade dos cursos de formação de professores trabalharem com tais aspectos.

\subsection{Estágio de Observação}

A apresentação dos resultados sobre o Estágio de Observação será analisado para cada licenciando em separado, com o intuito de descrevermos o processo de mudanças e de aprendizagens de cada um. A relação desta etapa com nossos objetivos de pesquisa é que percebemos que em muitas ocasiões os licenciandos consideraram suas experiências no Estágio de Observação para elaborarem sua regência. Assim, apresentar os dados desta etapa em que os licenciandos têm contato com os alunos da escola básica poderá nos auxiliar a entender suas ações no que tange a implementação de atividades de natureza argumentativa.

Destacamos, que todas as atividades de Estágio foram realizadas pelos licenciandos na mesma escola e com a mesma professora de Química do Ensino Médio. Ao final do primeiro dia de Estágio, cada licenciando apresentou critérios que consideravam importantes em uma observação desta natureza. Critérios estes que foram depois discutidos pela docente da disciplina.

\section{Licencianda Beatriz}

Como elementos a serem considerados durante o Estágio de Observação, Beatriz apresentou: a) reação dos alunos ante a solicitação do professor à realização de exercícios, b) critério de avaliação do professor, c) interesse dos alunos nos conteúdos abordados e d) na presença de alunos com deficiência como os demais se comportam e qual a metodologia de trabalho do professor.

As considerações realizadas pela licencianda em relação ao seu Estágio de Observação envolvem sua impressão de que os alunos do Ensino Médio, em sua maioria, não apresentam interesse no estudo e estão cada dia mais indisciplinados, a licencianda chega a relatar um episódio em que uma aluna discutiu com a professora de Química da escola. Porém, para Beatriz há alguns que se interessam pelo conteúdo abordado, que fazem questionamentos nas aulas e que há uma diferença significativa de uma sala para outra em relação aos aspectos acima mencionados. 
Em relação à postura da professora em suas ações didáticas, a licencianda destaca que a mesma em determinados momentos cria um espaço favorável para que os alunos participem, no entanto, o retorno nem sempre é o esperado. A licencianda relata que neste período de Estágio de observação a professora solicitou que ela ministrasse uma aula sobre Usina Nuclear. Em seu relato, apresenta que teve dificuldades na condução da mesma, mas que questões interessantes, sobre o conteúdo surgiram por parte dos alunos. Destaca-se, também que a mesma procurou orientações para a elaboração de sua aula em diferentes fontes, incluindo profissionais da universidade.

Elaborei uma apresentação no programa PowerPoint, procurei colocar assuntos relacionados com o tema proposto e com o conteúdo de química, tais como: isótopo, fissão nuclear, fusão nuclear e radiatividade. Inseri dois vídeos na apresentação: um sobre o recente acidente da usina nuclear no Japão e outro vídeo elaborado pela revista Veja, sugerido pelo Jair (monitor da universidade). Estudei sobre o tema, li os artigos sugeridos pela professora Joana (docente da universidade), elaborei os slides, mas tive um pouco de dificuldade durante a apresentação. Não foram todos os alunos que se interessaram pela apresentação, além de ocorrer conversas entre eles durante a mesma, mas alguns alunos fizeram perguntas bem interessantes, que eи е o Tales (estagiário) respondemos.Gostei de ver o interesse de dois alunos, que fizeram várias perguntas e colocaram suas ideias sobre o tema, isso ocorreu depois da aula. Na aula seguinte, na mesma sala, foi passado um vídeo sobre o acidente da usina nuclear Chernobyl (na aula do dia 4 de abril os alunos leram um texto sobre esse acidente). (Fonte: Blog)

\section{Licenciando João}

João apresentou como elementos a serem observados em sala de aula: a) o desinteresse dos alunos; b) o desinteresse dos professores e c) o ambiente físico da escola. Em suas observações, João relata as dificuldades do cotidiano de uma professora, em que destaca o pouco tempo efetivo de aula. Aborda que em uma aula de 50 minutos a professora desenvolveu o conteúdo apenas nos últimos 10 minutos e que somente na quarta aula é que ela conseguiu efetivamente escrever alguma coisa na lousa, conforme trecho abaixo

Após o intervalo, fomos para a sala do segundo ano A. Nesta aula, a professora conseguiu, pela primeira vez no dia, escrever alguma coisa na lousa, mas precisamente um quarto da lousa, algo sobre molaridade. (Fonte: Blog) 
Outro episódio destacado é que em uma aula a professora, inicialmente, verificou quem havia realizado a tarefa e obteve que a maioria não a tinha feito, então tentou realizar com os alunos os exercícios. No entanto, eles demonstravam total desinteresse. João aborda também a falta de estrutura física da escola, relata que ao tentar ir ao laboratório para pegar algumas vidrarias se deparou com uma porta sem maçaneta, o que o impossibilitou a obtenção dos materiais. O licenciando, ao terminar seu relato de Estágio de Observação, evidência que existem alguns mecanismos que ocorrem nas escolas que dificultam a ação docente.

\section{Licencianda Marta}

Quantos aos elementos de observação, Marta elencou: a) ambiente físico; b) disposição dos grupos dentro das salas; c) materiais didáticos utilizados nas aulas; d) reação da professora em relação às atitudes dos alunos; e) perspectiva do professor em relação aos estagiários e e) prioridades dos alunos.

Marta inicia sempre seus relatos destacando o tempo que a professora perde para tentar colocar os alunos sentados de forma a minimizar as conversas paralelas e para fazer a chamada. A licencianda cita que ao chegar à sala de aula esperava encontrar as carteiras dispostas em fileiras. No entanto, para sua surpresa, as mesmas eram agrupadas de acordo com as afinidades entre os alunos. Esse aspecto foi tratado por Marta com a professora a qual explicou o que promoveu tal situação, conforme pode ser observado no trecho abaixo.

Neste dia, a professora me contou a evolução do arranjo das carteiras nas salas
da escola. Originalmente, todos se sentavam em fileiras como na minha época.
Depois, os alunos criaram um U na sala, alegando que assim poderiam ver as
pessoas que estavam falando algo dentro da sala. Esse arranjo deteriorou-se
para uma disposição disforme, que contribui para a bagunça geral. Na última
reunião da escola, havia sido decidido que todos deveriam sentar-se separados
para diminuir a conversa, mas com uma aula de 50 minutos, perder 10 só para
arrumar a sala é uma perda considerável de tempo. (Fonte: Blog)

Marta relata que nas salas de aula onde o estágio foi realizado existiam alguns estudantes portadores de deficiência auditiva. Nessas salas a professora procurava escrever as respostas dos exercícios na lousa, o que não faz nas outras salas. O que indicava uma busca da professora em tornar o conhecimento mais acessível a esses 
alunos. No entanto, muitas das informações eram transmitidas aos alunos de forma verbal, o que dificultava o entendimento e a participação destes alunos.

No seu relato, a licencianda também destaca episódios em que os alunos se mostram bem interessados pelo assunto abordado nas aulas e outros em que não mostram o menor interesse, vindo em muitos casos a atrapalhar a dinâmica da aula. A licencianda destaca que, mesmo a professora sendo receptível aos estagiários, ela (estagiária) acredita que estes modificam o ambiente de sala de aula de uma maneira que vem a distrair os alunos, já que estes querem conversar com o estagiário, obter informações sobre a universidade, saber de seus gostos e inclusive saber que músicas gostam.

\section{Licenciando Pedro}

Os elementos de observação sugeridos por Pedro envolvem: a) observação da maneira como a aula é conduzida pela professora; b) reflexão por parte do licenciando como ele agiria se fosse o professor da situação vivenciada; c) ter contato com os cadernos do governo ${ }^{8}$ no que concerne ao ensino de Química e ao projeto do professor e d) ter contato com o quadro de profissionais da escola para ouvir suas histórias, a fim de ter um panorama da realidade escolar.

Pelo fato de Pedro ser egresso do Ensino Médio da escola em que foi realizar o Estágio, o mesmo apresenta uma análise das mudanças ocorridas desde sua saída. Os aspectos por ele mencionados levam-nos a entender que a escola com o passar dos anos, apresentou uma melhora significativa no que diz respeito à violência e à estrutura física. No entanto, ainda destaca problemas dessa natureza, conforme trecho abaixo.

\footnotetext{
${ }^{8}$ O governo do Estado de São Paulo instituiu no ano de 2007 o Programa São Paulo Faz Escola cujo objetivo foi a implementação de um currículo pedagógico único para todas as mais de 5 mil escolas da rede pública estadual.Com o programa, todos os alunos da rede estadual receberam o mesmo material didático e seguem o mesmo plano de aula. A Coordenadoria de Gestão da Educação Básica disponibiliza aos alunos da rede estadual o conteúdo do currículo proposto (Currículo, Cadernos do Gestor, Cadernos do Professor e Cadernos do Aluno) a fim de consolidar a articulação com o currículo em ação nas salas de aula de todo o Estado. Fonte: http://www.educacao.sp.gov.br. Destacamos que na linguagem do cotidiano escolar estes materiais tendem a serem chamados de "Caderno do Governo", como mencionado pelo licenciando Pedro.
} 
[...] como ex-aluno da escola gostaria de apontar alguns aspectos que a escola evoluiu desde meu tempo, a escola está mais bem frequentada sem problemas de gangues, tal como acontecia na minha época, aperfeiçoou a estrutura da escola, espaço físico: modificou e reformou o pátio, colocou portões e portas nas salas. Contudo, ainda ocorrem certos problemas como indisciplina pontuando: conversa em sala da aula, dispersão, falta de atenção e falta de interesse por parte dos alunos, problemas estes que também aconteciam na minha época de aluno. (Fonte: Blog)

Pedro aborda em vários de seus relatos a dificuldade da professora em fazer com que os alunos parassem de conversar e prestassem atenção na explicação. $O$ próprio licenciando apresenta um possível motivo do desinteresse dos alunos, argumentando que, pelo fato destes serem oriundos de um nível social baixo e passarem por dificuldades, não relacionam a Química ao seu cotidiano, conforme trecho abaixo.

Quanto aos alunos, bom como na minha época os alunos vem de diversas realidades (bairros, nível social, passam por dificuldades etc), o que explica a atitude deles para com a química, uma vez que por causa destas realidades eles não vivenciam (entendem as aplicações dos conceitos químicos) ou vivenciam muito pouco a química no seu dia-a-dia. (Fonte: Blog)

O licenciando, em suas postagens, apresenta que a professora utiliza constantemente o caderno do Governo como recurso em suas aulas. Destaca que, mesmo a professora usando do método de contar os vistos no caderno para emitir uma das notas, muitos dos alunos não fazem a lição e alguns apresentam poucos vistos.

A professora da escola básica solicitou ao estagiário que fizesse uma apresentação sobre molaridade, na qual o mesmo fez uso de demonstração experimental para abordar o assunto. Estratégia que, segundo Pedro, em uma sala de aula colaborou no entendimento dos alunos em relação à temática e, na outra, por falta de tempo e de material apropriado, não surtiu o efeito desejado. Pedro, destacou também três episódios de violência na escola, não diretamente relacionados às aulas de Química, mas que compunham o quadro escolar, conforme pode ser observado nos trechos a seguir.

A primeira aula foi na primeira série do Ensino Médio A, logo que entramos na sala notei uma certa agitação na sala ao lado que pertencia à primeira série do ensino médio C. Essa agitação era um desentendimento entre alunas. A professora foi averiguar a situação, enquanto eu fiquei na sala do primeiro A, 
não sei a causa desse desentendimento e nem como ocorreu (de maneira violenta ou não). (Fonte: Blog)

[...] ao fim do intervalo fui para a sala do primeiro $C$, enquanto me dirigia para lá, na diretoria observei um aluno que foi agredido no banheiro por outro aluno de outra sala e que também iria conversar com o diretor. (Fonte: Blog)

[...] Então, após irmos ao laboratório escolher a vidraria apropriada para atividade retornamos à sala dos professores. Enquanto estávamos na sala do professores conversando sobre como conduzir a atividade e como lidar com a câmera, pude observar 2 alunos do fundamental que haviam se agredido $e$ estavam para conversar com o diretor. (Fonte: Blog)

\section{Licencianda Rose}

Os elementos que Rose destaca como fundamentais ao realizar um Estágio de Observação, envolvem: a) comportamento dos alunos em sala de aula (discurso, organização, interesse pela disciplina); b) comportamento do professor diante ao desinteresse dos alunos e c) conteúdo abordado em sala de aula.

Em relação às atitudes dos alunos em sala de aula a licencianda destaca a indisciplina dos mesmos, a falta de interesse nos conteúdos abordados e em muitos casos o desrespeito com a docente. Rose destaca que em muitos momentos os alunos simplesmente não participavam das aulas, se negavam a realizar a prova, e mesmo ao olhar de três pessoas (estagiários e professora) "colavam", ouviam música e realizavam conversas paralelas, conforme pode ser observado no trecho a seguir.

Eu e o Tales ajudamos a professora a fiscalizar os alunos nas provas para que eles não "colassem”. Mas percebemos que mesmo sob o olhar de três pessoas, os alunos não se sentiam intimados e perguntavam ou copiavam as questões dos colegas ao lado. Tanto é que em uma sala de primeiro ano, a professora se sentiu incomodada com essa situação e mandou chamar a direção e três alunos tomaram advertência por esse ato. Notou-se também em algumas turmas, a falta de respeito com o professor durante a prova, pois alguns alunos usavam fone de ouvido para escutar música enquanto faziam a prova. (Fonte: Blog)

Rose dá um destaque a uma situação ocorrida em sala de aula que ao se formarem grupos para a realização de uma atividade a aluna com deficiência auditiva a princípio não foi aceita em nenhum grupo. Os argumentos utilizados pelos alunos eram que não sabiam se comunicar com a aluna, sendo que somente após a insistência da professora um grupo a recebeu. A licencianda destaca que nem os 
alunos, nem a professora possuíam uma preparação adequada para se comunicarem com alunos com deficiências. No entanto, a mesma se alegra ao saber que dois professores resolveram realizar o curso de linguagem de sinais e inclusive já estavam tendo resultados positivos em relação à comunicação com a aluna.

\footnotetext{
Durante o intervalo uma boa notícia, fiquei sabendo que dois professores estão fazendo curso gratuito de libras para poder se comunicar com a aluna deficiente auditiva do terceiro ano. Uma professora me disse que ficou feliz, pois tentou se comunicar com a aluna especial, com o pouco que aprendeu no curso e a aluna correspondeu. (Fonte: Blog)
}

Quanto à professora, a licencianda relata que esta encontra-se desmotivada em lecionar, por causa da falta de respeito e desinteresse dos alunos. No entanto, segundo Rose, a docente mantém o comprometimento com suas atividades docentes, realiza as provas em coerência com o que ensina em sala de aula e tenta fazer com que os alunos participem de suas aulas.

\section{Licenciando Tales}

Tales, não fez nenhuma sugestão dos elementos a serem utilizados na observação das aulas. O licenciando em seu relato focou bastante no desinteresse dos alunos pelo ensino e na indisciplina, tendo presenciado e relatado uma ação que envolve falta de respeito em relação à professora. Quanto às ações da professora, Tales menciona que a mesma tem grande preocupação em preparar a aula, em usar o caderno do governo e de ser coerente em relação ao conteúdo abordado e à prova, conforme pode ser observado no trecho abaixo.

Com relação às provas, achei muito interessante o jeito que a professora fez as provas. Esta abrangia todo o conteúdo contendo questões de múltipla escolha, de verdadeiro ou falso e dissertativas. Tive oportunidade de olhar a prova do primeiro colegial e a apostila na qual a professora se baseou para fazer tal avaliação. Pelo que observei a avaliação concorda com o conteúdo ensinado na apostila. (Fonte: Blog)

Um aspecto observado pelo licenciando foi à dificuldade que os alunos possuem em interpretar os enunciados das questões, o que por muitas vezes acaba gerando erros nas respostas. Além disso, são poucos os que se interessam em fazer perguntas relacionadas aos assuntos abordados. 


\subsection{Atividades sobre argumentação}

Os dados da oficina de leitura foram analisados e identificados nas falas dos sujeitos envolvidos no processo, os aspectos referentes à argumentação em sala de aula. Os mesmos foram divididos em três categorias Argumentação (Quadro 18), Estratégias de Ensino (Quadro 19) e Necessidades do Professor (Quadro 20). Observamos que foram abordados aspectos que remetiam diretamente às estratégias a serem desenvolvidas em sala de aula, com ênfase na atitude do professor para fomentar um ambiente argumentativo e de aspectos gerais da argumentação.

QUADRO 18: ASPECTOS MENCIONADOS PELOS LICENCIANDOS E PELA DOCENTE DA DISCIPLINA SOBRE CARACTERÍSTICAS DA ARGUMENTAÇÃO EM SALA DE AULA.

\begin{tabular}{|c|c|}
\hline & Características \\
\hline \multirow{5}{*}{ 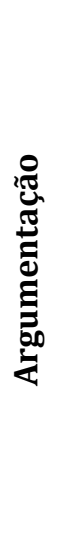 } & $\begin{array}{l}\text { Argumentação é uma atividade social, discursiva em que } \\
\text { temos que justificar os pontos de vista e considerar as } \\
\text { perspectivas contrárias as nossas. }\end{array}$ \\
\hline & Pode ocorrer em diferentes contextos. \\
\hline & $\begin{array}{l}\text { Não envolve somente o debate entre duas pessoas, pode } \\
\text { ser realizada, por exemplo, em uma apresentação. }\end{array}$ \\
\hline & $\begin{array}{l}\text { Auxilia na compreensão dos alunos em relação aos } \\
\text { conceitos científicos e da Natureza da Ciência. }\end{array}$ \\
\hline & Auxilia no desenvolvimento do senso crítico do aluno. \\
\hline
\end{tabular}




\section{QUADRO 19: ASPECTOS MENCIONADOS PELOS LICENCIANDOS E PELA DOCENTE DA DISCIPLINA SOBRE ESTRATÉGIAS QUE PODEM SER UTILIZADAS NA PROMOÇÃO DA ARGUMENTAÇÃO EM SALA DE AULA.}

\section{Características}

Auxilia na identificação dos conhecimentos prévios dos alunos e visa uma mudança de determinado assunto.

O professor deve agir como mediador sendo flexível para direcionar as conclusões do debate para o esperado por ele.

0 professor deve selecionar conteúdos que promovam a discussão dos alunos e a construção dos argumentos.

0 aluno deve ter um papel ativo.

Os alunos precisam ter espaço para discutir com seus colegas.

0 professor pode avaliar além do conteúdo a manifestação de habilidade cognitiva e o desenvolvimento de argumentos por meio da escrita.

É importante ser uma atividade de caráter investigativo.

Diminui o distanciamento entre o aluno e o professor, pois fazem parte do mesmo processo de descoberta e criação de atitudes e ações que levam à melhor compreensão dos conceitos.

Auxilia no desenvolvimento da linguagem Química.

Aluno apresenta um maior envolvimento nas etapas da atividade.

Os alunos precisam elaborar com qualidade e fundamentar os argumentos no intuito de convencer o próximo.

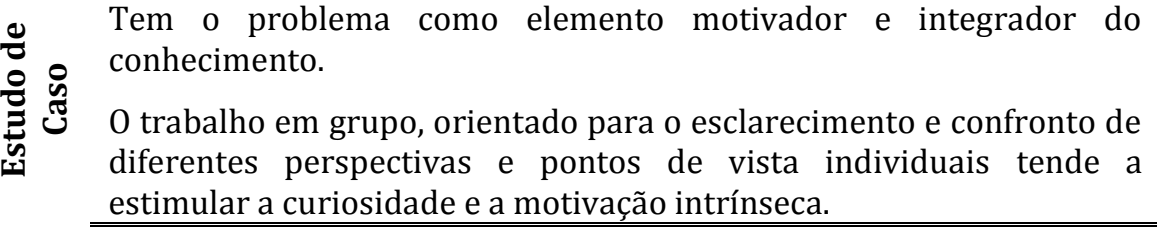

\section{QUADRO 20: ASPECTOS DISCUTIDOS PELOS LICENCIANDOS E PELA DOCENTE DA DISCIPLINA SOBRE AS NECESSIDADES FORMATIVAS E ATITUDE DO PROFESSOR NO DESENVOLVIMENTO DE ATIVIDADES QUE VISEM À PROMOÇÃO DA ARGUMENTAÇÃO EM SALA DE AULA.}

\begin{tabular}{cl}
\hline \hline & \multicolumn{1}{c}{ Características } \\
\hline \hline & Conhecer os elementos básicos de um argumento (Modelo de Toulmin). \\
& Conhecer pesquisas em que se analisa se existe espaço para a \\
& argumentação nas salas de aulas de Ciências. \\
& Analisar a qualidade dos argumentos. \\
& Ter em sua formação espaços para leitura de trabalhos relacionados à \\
& nesta perspectiva. \\
& Ter conhecimento de que a maneira como realiza uma pergunta ao aluno \\
pode influenciar na promoção ou não da argumentação.
\end{tabular}


O vídeo utilizado para trabalhar a atividade investigativa da prática docente, inicia com o professor propondo um problema experimental a ser resolvido em grupos de 4 a 5 alunos. Para todos os licenciandos a primeira ação realizada pelas docentes foi à escolha do problema, o qual consistiu em um experimento de caráter investigativo em que os alunos precisavam colocar uma "bolinha" em uma cestinha ao final do looping. No entanto, somente um licenciando no primeiro texto identifica o caráter investigativo do problema, os demais apenas o descrevem. Já após o estudo, os licenciandos abarcam este aspecto em seu texto. Por exemplo, no primeiro texto da licencianda Marta, esta apenas descreve a atividade realizada, já no segundo identifica a natureza do experimento e como este possibilita a construção do conhecimento por parte dos alunos.
As professoras utilizaram uma atividade prática, no caso, um loop com uma cestinha e bolinha. As professoras pediram que os alunos soltassem a bolinha no trilho do loop e acertassem a cesta. [MARTA 1] (Fonte: Texto da licencianda)
A atividade não é um experimento para verificar algo já visto na teoria, mas uma proposta onde os próprios alunos constroem seu conhecimento a partir da manipulação de objetos e socialização de suas impressões e deduções com a orientação das professoras. [MARTA 2] (Fonte: Texto da licencianda)

Além da apresentação da natureza do problema, outros aspectos são mencionados no segundo texto pelos licenciandos, que concernem à elaboração do experimento. No primeiro texto, os licenciandos em sua maioria mencionam, apenas que o mesmo foi realizado, e somente a Marta e a Beatriz descrevem aspectos da sua execução, conforme descrito nos trechos abaixo.

Os alunos puderam tentar várias vezes até acertar sem serem interrompidos pela professora. [MARTA 1] (Fonte: Texto da licencianda)

No início da realização desse experimento os alunos tiveram dificuldades em resolver o problema, após várias tentativas eles começaram a entender o experimento e consequentemente a "resolver o problema" proposto pela professora. Os alunos com suas próprias capacidades intelectuais chegaram na "solução do problema". [BEATRIZ 1] (Fonte: Texto da licencianda)

Já no segundo texto, os licenciandos destacam que os professores solicitam que todos os alunos deveriam participar da atividade. Além disso, mencionaram que durante a atividade os alunos, por tentativas e erros, levantaram hipóteses, controlaram variáveis e criaram relações para a solução do problema. 
Durante o experimento os alunos percebem que jogando a bolinha somente no começo do trilho, ela não atinge a cesta, pois sai do trilho antes de alcançar o ponto da cesta. Então eles começam a testa diferentes posições de arremesso da bolinha, até que eles acertam. [ROSE 2], (Fonte: Texto da licencianda)

Os alunos entraram em contato com o experimento tentando encontrar a solução. Este foi o ponto em que cada aluno vivenciou a situação apresentada e tentou encontrar a resolução do problema por meio de tentativas e erros. [TALES 2], (Fonte: Texto do licenciando)

Durante a atividade pode-se observar o desempenho dos alunos que por tentativa e erro, conseguiam criar uma relação com a altura de lançamento da bolinha com o destino final, isto é, o cestinho. [PEDRO 2], (Fonte: Texto do licenciando)

No segundo texto, os licenciandos destacaram o papel do professor como mediador, mencionaram que as perguntas do professor direcionavam a discussão, de maneira que as diferentes ideias fossem expostas, trabalhando com as variáveis apresentadas pelos alunos, levando a uma conclusão coletiva. Outro aspecto mencionado foi o fato do professor contextualizar o assunto abordado e de dar espaço para os alunos falarem, o que possibilitou ter um feedback do conhecimento dos mesmos. Pode-se observar tais ideias nos trechos a seguir dos licenciandos Beatriz, João, Marta e Tales.

O professor no momento da discussão foi um mediador da discussão, fez perguntas baseadas nos seus objetivos, além disso, direcionou os alunos para que não fugisse dos seus objetivos, além disso, perguntou onde eles encontravam isso no dia-a-dia, fazendo assim uma contextualização. Percebeu também que o professor deixou os alunos exporem suas ideias, o que é importante, pois assim, o professor pode perceber o que os alunos aprenderam. [BEATRIZ 2], (Fonte: Texto da licencianda)

[...] fica evidente que a maioria dos alunos possuíam uma certa concepção em relação ao experimento e diante da não validade deste conhecimento, eles tinham que buscar novas respostas e assim mudando suas concepções. Ainda nesta etapa a discussão contribuiu para o refinamento das ideias dos alunos, pois várias possibilidades foram levantadas para a ocorrência do fenômeno, mas ao final o professor conseguiu direcionar e mostrar aos alunos quais ideias eram mais corretas na experiência em questão. [JOÃO 2], (Fonte: Texto do licenciando)

[...] o fato de terem que compartilhar suas ideias diante do grupo favoreceu o desenvolvimento das habilidades de expressão e linguagem dos alunos, pois eles devem contar de forma clara o que aconteceu e como fizeram. [MARTA 2] (Fonte: Texto da licencianda) 
[...] a terceira estratégia consiste na explicação do aluno com suas palavras ao fato. Observa-se nesta etapa que o aluno tenta relacionar o que viu e vivenciou com seus conhecimentos utilizando-os como argumentos para explicar o fenômeno. Ainda utiliza dos termos que conhecem como "velocidade", "devagar", "rápido", "alto", "força”, para tentar explicar, juntamente com gestos das mãos. Nota-se aqui uma tentativa de construir um argumento, a partir de seus conhecimentos prévios, dos fatos observados. [TALES 2], (Fonte: Texto do licenciando)

A última ação realizada pelos alunos do vídeo e também identificada pelos licenciandos foi a representação da atividade desenvolvida por meio de desenho e textos. Observamos que no primeiro texto apenas a licencianda Rose, menciona tal ação, já no segundo, esta é identificada por quatro dos seis licenciandos. De acordo com estes, a referida atividade permitiu uma sistematização do conhecimento dos alunos, conforme mencionado nos trechos a seguir.

[...] no último passo, é pedido aos alunos para fazerem uma descrição em papel
sobre toda a experiência, tanto com palavras quanto com desenhos, está etapa
pode ser considerada um exercício de fixação para os alunos e também, uma
forma de ordenar suas ideias utilizando todos os elementos familiares
(desenhos) e os que estão sendo aprendidos (linguagem escrita). [MARTA 2],
(Fonte: Texto da licencianda)

[...] esta é outra forma de tentar identificar nos seus textos argumentos que expliquem o fenômeno. [TALES 2], (Fonte: Texto do licenciando)

Podemos destacar que os licenciandos após o estudo sobre as atividades de formação de conhecimento sobre argumentação, conseguem perceber aspectos importantes da aula analisada, sendo a importância da escolha do problema, o qual deve proporcionar um ambiente investigativo aos alunos, a necessidade de que todos tenham a oportunidade de manusear o aparato experimental, o surgimento de hipóteses, variáveis e o uso destes aspectos à construção do conhecimento. Destacaram também, a importância de proporcionar espaço aos alunos para que possam apresentar seus argumentos sobre como resolveram o problema e de ações dos professores que proporcionam a elaboração de argumentos por parte dos alunos.

Em uma análise qualitativa, observamos que, em geral, os licenciandos no primeiro texto apresentaram um caráter mais descritivo às atividades e já no segundo realizam uma análise do motivo de determinada ação e o que ela proporcionou na construção do conhecimento dos alunos. 


\subsection{Atividades de regência}

Serão apresentados os resultados de cada licenciando em relação ao processo inicial de elaboração do projeto de regência até os momentos de reflexão realizados individualmente e coletivamente. Iremos seguir uma sequência de apresentação dos dados, os quais não estarão divididos em itens como expresso no Quadro 21, mas poderão ser identificados no decorrer do texto.

\section{QUADRO 21: ASPECTOS ANALISADOS NAS ATIVIDADES DESENVOLVIDAS PELOS LICENCIANDOS EM RELAÇÃO À ELABORAÇÃO, APLICAÇÃO E REFLEXÃO SOBRE A REGÊNCIA.}

\begin{tabular}{l} 
Aspectos a serem observados \\
\hline \hline 1. Vertente escolhida pelo licenciando para abordar a temática. \\
2. Estrutura da regência. \\
3. Descrição da(s) atividade(s) escolhida para promover a argumentação. \\
4. Concepção do licenciando sobre o papel que a(s) atividade(s) argumentativa \\
deveria assumir em sua regência. \\
5. Dificuldades e/ou facilidades no desenvolvimento das atividades de natureza \\
argumentativa. \\
6. Como ocorreu a participação dos alunos ante as atividades desenvolvidas pelo \\
licenciando. \\
7. Quais características/ações um professor precisa ter/fazer para desenvolver \\
atividades de natureza argumentativa em sala de aula. \\
8. Reflexão do licenciando em relação a todo o processo.
\end{tabular}

\section{Licencianda Beatriz}

Beatriz tinha como tema de regência Eletroquímica e a ministrou para alunos do segundo ano do Ensino Médio. A licencianda optou conduzir as duas primeiras aulas de forma expositiva alternando sua apresentação com os recursos de lousa/giz e PowerPoint (Quadro 22). Para Beatriz, a atividade elaborada envolvia a realização de um experimento em que ela manipularia o aparato experimental e faria questionamentos buscando promover a argumentação dos alunos. 


\section{QUADRO 22: ATIVIDADES DESENVOLVIDAS POR BEATRIZ PARA CRIAR UM AMBIENTE ARGUMENTATIVO}

DURANTE AS AULAS DE QUÍMICA DO ENSINO MÉDIO.

\begin{tabular}{|c|c|}
\hline Aula & Atividades desenvolvidas \\
\hline $\begin{array}{l}1^{o} \text { e } 2^{\circ} \text { aula } \\
\text { (100 minutos) }\end{array}$ & $\begin{array}{l}\text { Aula expositiva sobre a temática usando } \\
\text { lousa/giz e o PowerPoint. }\end{array}$ \\
\hline $\begin{array}{l}3^{\circ} \text { e } 4 \stackrel{\text { o aula }}{ } \\
(100 \text { minutos })\end{array}$ & $\begin{array}{l}\text { Realização de experimento com } \\
\text { realização de questionamento aos alunos } \\
\text { com o intuito de suscitar discussão. }\end{array}$ \\
\hline
\end{tabular}

A atividade de argumentação foi baseada na estratégia de Laboratório Aberto, em que a licencianda tentou fazer perguntas que pudessem identificar as hipóteses dos alunos durante a realização de um experimento. Destacamos que o experimento foi realizado em caráter de demonstração. Beatriz optou por esta estratégia por ter tido contato com o artigo de Suart e Marcondes (2010) durante a disciplina de Prática do Ensino de Química, que mostrava resultados positivos na promoção da argumentação ao trabalhar com laboratório aberto com alunos do Ensino Médio.

(considerações de Beatriz sobre a atividade de natureza argumentativa realizada) Eu tentei desenvolver o Laboratório Aberto e tentei fazer perguntas antes, perguntando para ver o que eles achavam que estava acontecendo para ver se eles sabiam alguma coisa, tentando responder algo que eu estava esperando. (Fonte: Entrevista)

(considerações de Beatriz sobre o critério base para a escolha da estratégia) Então, como eu tive a experiência na disciplina de argumentação (se referindo a um dos artigos utilizados na oficina de leitura), como eu falei, eu achei interessante e como no conteúdo tinha muito experimento ai eu achei que seria um bom método para o conteúdo que foi aplicado na regência. (Fonte: Entrevista)

A licencianda aponta que teve algumas dificuldades em relação ao desenvolvimento da atividade no que concerne à elaboração de perguntas que iria realizar aos alunos, considera que não há materiais que possam orientar os professores neste desenvolver metodológico ligado ao uso das questões em atividades experimentais.

(considerações de Beatriz sobre os aspectos referentes à elaboração da atividade argumentativa) Eu acho que o entendimento, assim, pra elaborar as questões, que eu fiz, eu acho que teria que ser melhor. Não sei. Talvez 
estudando. E ainda mais que normalmente, quando tem um experimento, é um experimento para comprovar coisas teóricas, né? E ali era um experimento que eles teriam que entender o que estava acontecendo de fato. E eu pelo menos não encontrei nenhum material que me ajudasse a elaborar estas questões. Sabe, algum material que tivesse algumas questões que pudesse me orientar eu elaborar as minhas questões. (Fonte: Entrevista)

Ao analisar sua regência, Beatriz considera que seus alunos argumentaram o que expressa num grau de "mais ou menos", pelo fato de não terem falado muito. Também, atribui este resultado à falta de compreensão dos alunos em relação à atividade, à falta de conhecimento deles sobre o assunto e o grau de complexidade da temática quando comparado a outros conceitos da área de Química. Além disso, considera que seu papel como mediadora ficou aquém do ideal.

(considerações de Beatriz sobre o critério utilizado para concluir se os alunos haviam ou não argumentado) Eu acho que eles poderiam ter falado muito mais do que eles falaram. Eu esperava que eles comentassem e falassem muito mais do que eles falaram e discutiram. (Fonte: Entrevista)

Analisando as falas da licencianda, abaixo transcritas, percebemos a explicitação de um entendimento que sua ação, como docente, é essencial para o sucesso ou fracasso de qualquer atividade que visa à aprendizagem dos alunos. Percebemos que elenca motivos para o insucesso de sua atividade na promoção da argumentação.

Entre os motivos considera o fato dos alunos não terem aprendido significativamente os conceitos sobre a temática o que dificultou a discussão. Considera também o fato dela como docente não ter conseguido gerar questões numa perspectiva argumentativa e não conseguir conduzir o diálogo dos alunos de forma que pudessem justificar seus diferentes pontos de vista, o que contribuiria para aprender os conceitos.

(considerações de Beatriz sobre a suscitação da argumentação dos alunos durante as aulas) Eu acho que mais ou menos. Porque eu acho que os alunos ficaram meio confusos, porque eu acho que eles talvez não entenderam bem, ou deveriam ter estudado mais, ou que foi passado na aula anterior para compreender melhor o experimento para eles poderem tentar pensar, né? Talvez algumas questões que eu não fiz e tentei responder junto com eles. Eu fiz algumas questões e eles não respondiam e ai eu respondia por eles. Talvez não gerou muita discussão. Eu também acho que não gerou porque alguns não sabiam o conteúdo e acho também que era um conteúdo difícil de aprender. (Fonte: Entrevista) 
(consideraçães de Beatriz sobre a gestão da argumentação em aula) Eu fiz lá a pilha ai eu perguntava: Gerou energia? Por que gerou? Alguns respondiam e alguns não estavam nem ai. Mas assim, não teve nenhum momento que gerou muita discussão... teve um momento que um aluno disse que a placa tinha corroído e o outro achava que não tinha corroído, mas ai eu não consegui fazer discussão entre os dois, sabe. Eu perguntei mais não gerou a discussão, eu perguntei porque ele achava e perguntei o porque a outra achava, mas a outra só achava não tinha um motivo porque ela achava aquilo, ai não gerou a discussão entre eles. (Fonte: Entrevista)

Em uma análise do que modificaria na regência, Beatriz destaca que talvez se tivesse deixado os alunos realizarem o experimento, estes se sentiriam mais a vontade de responder aos seus questionamentos. Considera também que fez mais uma atividade demonstrativa do que um experimento aberto. Além disso, afirma que deveria ter trabalhado com os alunos mais a parte conceitual da temática, pois sentiu que estes não a tinham compreendido em sua totalidade, o que dificultou a participação na atividade experimental.

(considerações de Beatriz em relação ao que modificaria em uma nova apresentação da mesma regência) Eu acho que talvez deixando os alunos realizar um experimento em grupo e indo em cada grupo, e fazendo o questionário, e eles tentando responder de forma mais individual, talvez eles iam responder mais...Eu acho que eu fiz mais um experimento demonstrativo do que um de laboratório aberto, eu tentei questionar os alunos, mas eles não participaram. (Fonte: Entrevista)

Falando o que eu acho da minha regência, eu acho que eu deveria ter trabalhado muito mais a parte do que é oxidação o que é redução para depois tentar ir para o laboratório aberto, porque eles tinham dificuldade, eles sabiam que gerava corrente, eles viam que a plaquinha mudou, mas não sabiam explicar. (Fonte: Entrevista)

Embora não tenha obtido sucesso em sua regência, Beatriz considera fundamental a realização em sala de aula de atividades que criem um ambiente argumentativo, pois estas colaboram com o desenvolvimento cognitivo do aluno tornando-o uma pessoa mais culta, de melhor comunicação, mais crítica e ajuda o professor a direcionar o processo de ensino. A explicitação por parte da licenciada dos motivos aos quais se devem utilizar atividades argumentativas em sala de aula revela um Saber de Argumentação Docente dos Fins Educacionais.

Tal saber é fundamental na escolha da atividade a ser utilizada em sala de aula, já que sabendo aonde se quer chegar fica mais fácil escolher a estratégia que 
mais se adeque aos seus objetivos. Nos trechos abaixo tracejados ${ }^{9}$, identificamos a explicitação de Beatriz sobre algumas finalidades das atividades argumentativas. Para a licencianda, atividades desta natureza têm por objetivo desenvolver no aluno a capacidade de pensar, de se expressar e de ser mais crítico diante as decisões a serem tomadas.

(considerações de Beatriz sobre o motivo de ser importante desenvolver atividade argumentativa em sala de aula) Porque você desenvolve a capacidade de pensar do aluno e desenvolve uma maneira dele falar porque se ele não fala de uma forma correta a pessoa não vai entender... Acho que vai torná-lo (o aluno) uma pessoa até mais culta. Vai saber se expressar melhor, de forma mais clara. Evai poder ser crítico diante as coisas. (Fonte: Entrevista)

(considerações de Beatriz sobre a função da atividade argumentativa) Eu acho que na atividade argumentativa dava para perceber melhor que o aluno sabe eo que ele está entendendo e tentar focar no que você quer ensinar mesmo além do aluno se tornar uma pessoa mais crítica. (Fonte: Entrevista)

Em relação aos aspectos que dificultam a argumentação dos alunos, a licencianda destaca o desinteresse dos mesmos e a falta de conhecimento dos alunos em relação à temática. Para ela estes aspectos impossibilitam promover em sala de aula uma discussão mais fundamentada. Além disso, Beatriz destaca o fato dos alunos não terem o hábito de participar de atividades de natureza argumentativa.

(considerações de Beatriz em relação aos aspectos que dificultam a argumentação dos alunos) Eu acho que muitos têm preguiça de pensar e também a falta de atividade de argumentação que tem na sala de aula. E a base teórica dos alunos que dependendo eles não têm muito conhecimento e vai discutir alguma coisa mais avançada e não da para discutir sem conhecimento. (Fonte: Entrevista)

Ao realizar uma reflexão sobre as atividades desenvolvidas no curso as quais foram fundamentais a sua formação como docente, a licencianda destaca as vinculadas à disciplina que envolviam ações na escola de Educação Básica. Beatriz também aponta que durante as atividades sobre argumentação aprendeu muito com as discussões dos textos, pois podia compartilhar conhecimento com os demais sujeitos do processo.

\footnotetext{
${ }^{9}$ Ao longo da seção "Resultados" usaremos a marcação de tracejado para destacar as explicitações dos licenciandos de seus SADs.
} 
Para Beatriz, esse movimento de discussão, de planejamento, de implementação e análise das atividades de caráter argumentativo possibilitou o desenvolvimento de um conhecimento, que usando a nossa categorização podemos considerá-lo como SAD Relativo às Estratégias. Nos grifos abaixo, vemos Beatriz externando que aprendeu mais sobre suas ações docentes nas disciplinas vinculadas ao estágio, pois, foram nelas que pode além de vivenciar, obter conhecimento sobre a prática docente.

(consideraçães de Beatriz em relação à contribuição do curso, graduação, na sua formação como docente) Bom! Eu acho que as aulas teóricas foram importantes, algumas aulas práticas também foram importantes porque da base teórica para a gente. Mas acho que principalmente a disciplina de prática de ensino tanto de química quanto de ciências são elas as mais importantes onde eu mais aprendi. Porque você tem que ir elaborando o plano de aula um projeto de regência você vai à escola, você tem mais contato com os alunos, você aplica a aula. Aí eu acho que ganha mais experiência e mais conhecimento. (Fonte: Entrevista)

(considerações de Beatriz em relação às contribuições das atividades desenvolvidas durante a disciplina) Eu acho que aquela roda de discussões (se referindo a uma das etapas da oficina de leitura) foi onde eu mais aprendi. Ah! Porque às vezes algo você podia não entender direito e ai um entendia de uma forma que talvez facilitasse para minha compreensão. (Fonte: Entrevista)

(considerações de Beatriz em relação às contribuições que a regência proporcionou a sua futura atuação docente) Porque mesmo que é uma experiência mesmo com os erros que teve é só tentar melhorar. Eu acho que com os erros desta dá para melhorar e tentar fazer outra melhor. (Fonte: Entrevista)

Em relação aos aspectos que aprendeu ao desenvolver uma atividade de natureza argumentativa, a licencianda destaca a mudança na sua concepção no processo de ensino, pois conseguiu perceber que o conteúdo pode ser abordado em uma perspectiva além da tradicional. Beatriz, ainda destaca que um professor que deseja desenvolver uma atividade de natureza argumentativa, necessita saber argumentar e envolver os alunos nas atividades.

Vemos nas transcrições abaixo uma busca da licencianda por mostrar que sua concepção sobre a prática docente foi alterada, pois migrou de um modelo tradicional para um em que o aluno assume um papel mais ativo no processo de ensinoaprendizagem. Para Beatriz, essa nova prática, no que compete a promoção do ambiente argumentativo, requer do professor um conhecimento prático da 
argumentação e de mediar o diálogo. No entanto, a licencianda destaca que teve dificuldades em desenvolver tais aspectos na sua regência.

(considerações de Beatriz em relação ao que aprendeu no desenvolvimento da atividade de natureza argumentativa) Eu aprendi a tentar olhar de outra maneira o conteúdo da disciplina que eu for ministrar, porque não precisa ser transmitida da forma que está no livro, pode ser transmitida de outra forma tentando trazer os alunos a participarem. (Fonte: Entrevista)

(considerações de Beatriz em relação ao conhecimento que um professor precisa ter para desenvolver atividades numa vertente argumentativa) Eu acho que ele tem que saber argumentar bem também, para poder elaborar boas questões e ministrar bem. Tem que também saber chamar os alunos para a atividade. (Fonte: Entrevista)

\section{Licenciando João}

A temática de João envolvia os impactos sociais e ambientais decorrentes da extração de matérias-primas na sociedade, com foco na extração de ferro e cobre, e estava destinada a alunos do primeiro ano do Ensino Médio. João, ao preparar seu projeto inicial de regência, o estava focando somente nos aspectos socioambientais e apontava como justificativa o fato de estar se baseando nos Parâmetros Curriculares Nacionais do Ensino Médio (BRASIL, 2000), os quais preconizam a formação de um cidadão crítico.

(considerações de João sobre o foco que daria a sua regência) Olhando o PCN ele tem uma vertente que ele diz da formação do cidadão crítico em relação a alguns temas da sociedade eu foquei mais nessa parte por quê? Isso seria mais ou menos o que eles teriam que saber conhecimentos prévios sobre as atividades de extração, seria eles já tem que ter um conhecimento do que é extração e das transformações químicas que ocorrem. Então eu já estou indo com isso na cabeça de que eles sabem isso, que foi dado durante o ano. Por quê? Porque eu quero focar mais no impacto deste tipo de atividade na sociedade ... o objetivo geral é que eu quero que eles compreendam estes impactos. (Fonte: Vídeo- Aula Prática do Ensino de Química)

Após a discussão do projeto inicial durante uma aula da disciplina de Prática do Ensino de Química, João o modificou, pois sentiu a necessidade de englobar em sua regência aspectos das transformações químicas que ocorrem na indústria siderúrgica.

Vou trabalhar com transformação química porque eu tinha voltado muito para a parte do impacto social, mas lendo algumas coisas mais aprofundadas eu vi que 
realmente tem que falar um pouco de transformação química. (Fonte: VídeoAula Prática do Ensino de Química)

A sequência de ensino elaborada por João contava com quatro aulas, em que optou por trabalhar a parte teórica via apresentação em PowerPoint e nas três aulas seguintes as atividades de caráter argumentativo. As atividades desenvolvidas estão apresentadas no Quadro 23.

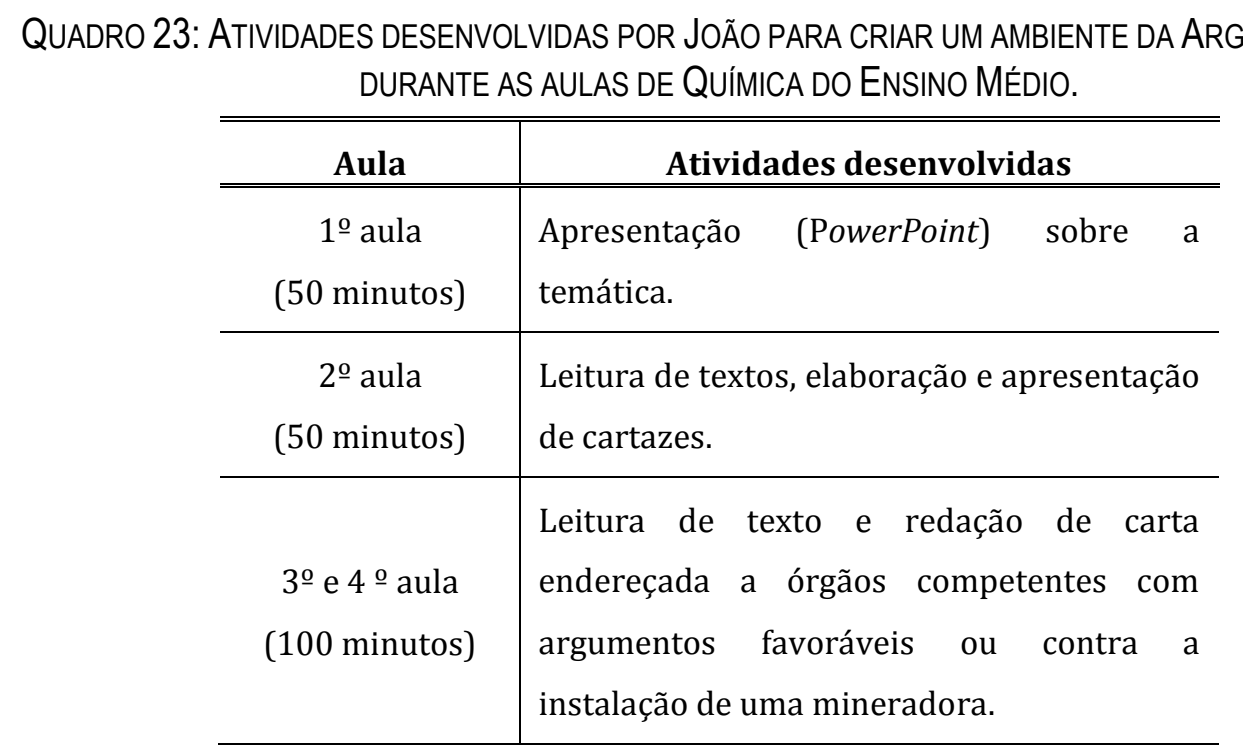

$\mathrm{Na}$ primeira aula, João fez uso de recurso audiovisual em formato de PowerPoint para abordar os conceitos com os alunos. Na segunda e terceira trabalhou com uma dinâmica de leitura de textos, os quais continham vantagens e desvantagens da extração mineral ao meio ambiente e à sociedade em geral. Nesta atividade, os alunos se dividiram em grupo (sendo entregue um texto diferente para cada grupo), e, inicialmente, cada aluno fez a leitura individual do texto e destacou pontos importantes. Em seguida, discutiram com os demais integrantes do grupo os pontos mais relevantes e fizeram um cartaz em que apresentaram aos demais colegas da sala seus apontamentos.

Para João, a atividade com uma vertente mais argumentativa e com caráter de avaliação foi desenvolvida na quarta aula. Na referida atividade, os alunos produziram um texto em que tinham que apresentar argumentos em relação à instalação de uma mineradora em sua região. Como base para a elaboração da carta, João resgatou os conceitos apresentados pelos alunos nos cartazes. Para o 
licenciando, os alunos participaram da atividade, reação ao qual o mesmo não acreditava que aconteceria.

[...] eles participaram da atividade argumentativa mesmo... não foi o que a gente esperava, 100\%, mas pelo menos eles participaram e é uma coisa que eu achei que não aconteceria ... (Fonte: Entrevista)

Em relação ao desafio de ter que elaborar uma atividade com foco na argumentação João apresenta que inicialmente teve certo desconforto e até mesmo receio em ter que elaborar uma regência com esta vertente. Ao longo de suas ações identificou como dificuldade o fato de não ter experiência em atividades desta natureza e também dos alunos da escola básica terem pouca prática em atividades argumentativas.

(consideraçães de João sobre sua reação ao saber que teria que desenvolver uma regência numa perspectiva argumentativa) Ah, no primeiro momento eu achei ... que seria impossível ... por mais que tenha visto tudo, eu senti muita dificuldade, mas depois que chegou no final e mais na hora que eu fui aplicar, que eu senti a facilidade. No processo eu sentia dificuldade, mas na hora que eu apliquei, que depois que você vê resultado também, né, por mais que não... a gente, né, não tem um "nossa senhora", tal, mas eu achei que foi mais fácil. (Fonte: Entrevista)

Para a elaboração da regência, João refletiu em qual atividade seria mais propícia à experiência dos alunos. O licenciando argumenta que desconsiderou usar um debate, pois este não seria adequado ao tempo reduzido que tinha e pelo fato dessa atividade poder inibir os alunos. Fica evidente na transcrição abaixo (grifos nossos) o SAD Relativo às Estratégias, pois, João explícita que escolheu esta estratégia por possibilitar trabalhar com os alunos divididos em pequenos grupos, num contexto de discussão possibilitando o ambiente argumentativo.

(considerações de João sobre a escolha da estratégia argumentativa) ... enu achei que um debate, por exemplo, também não se encaixaria por quê? Uma pelo tempo que eu tinha e pelo que eu queria tratar nas aulas e outra por eles ficarem meio acanhados na hora de falar. Então eu pensei "Não vamos tentar escrever com eles e também para trabalhar isso a interpretação de texto, que eles teriam que ler, e a atividade”. (Fonte: Entrevista)

Para João, a atividade argumentativa deveria possibilitar que os alunos transferissem para seu cotidiano os conceitos ensinados e, em especial, que pudesse contribuir para que estes desenvolvessem um espírito de cidadão crítico. Esta consciência do licenciando sobre o papel que a estratégia argumentativa deveria 
assumir em suas aulas possibilitou identificarmos o SAD dos Fins Educacionais e SAD Sociocientífico.

Observamos pelo texto destacado abaixo (grifos nossos) que ao considerar que os alunos deveriam aprender de forma a extrapolar os conceitos a seu cotidiano, o licenciando está apontando e justificando uma das finalidades de se trabalhar com a argumentação em sala de aula, levando a uma explicitação do SAD dos Fins Educacionais. Ao justificar que esta extrapolação deveria vir a contribuir com a formação de um cidadão crítico que atue ativamente em questões da sociedade, temos uma explicitação de João em seu SAD Sociocientífico.

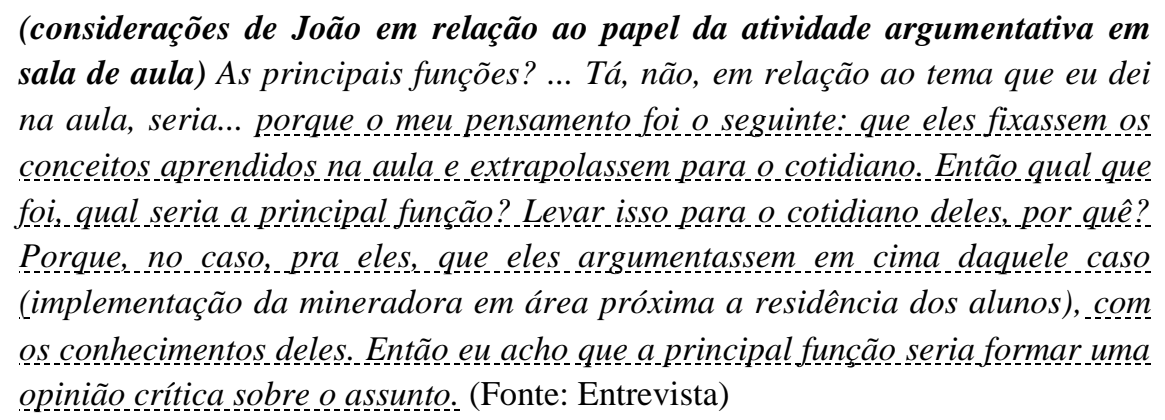

João se mostra satisfeito com sua regência, já que conseguiu, de uma maneira considerada por ele como satisfatória, fazer com que os alunos argumentassem. Para ele, a sequência em que as atividades foram realizadas possibilitou que os alunos fossem formando uma base de conhecimento em que pudessem entender os conceitos ensinados e extrapolassem para o seu cotidiano. João acredita que suas ações contribuíram para a promoção de um ambiente argumentativo.

Em relação ao seu posicionamento frente à efetividade das estratégias na promoção da argumentação, João revela-se totalmente satisfeito, pois conseguiu que todos os alunos participassem das atividades.

\footnotetext{
(considerações de João sobre a participação dos alunos na atividade argumentativa) ... uma coisa que eu fiquei feliz foi que todo o mundo participou, né? Isso aí pra mim já foi um ganho que eu achei demais. Ainda mais com tudo que a gente ouve né, que é escola pública, que a gente assistia aula com eles... eu participei da Feira de Ciências, que não foi uma adesão total de todos os alunos. Então, aí eu adotei essa estratégia. Todo mundo participou? Ponto positivo. (Fonte: Vídeo- Aula Prática do Ensino de Química)
}

Destacamos que o licenciando fez uma reflexão sobre suas concepções prévias sobre os alunos e os resultados obtidos com sua ação docente, expressando 
um SAD Relativo às Estratégias. Fica evidente uma mudança de posicionamento (grifos nossos), já que inicialmente João considerava que os alunos não participariam das atividades, e após as ações percebeu que é possível desenvolver atividades diferenciadas em sala de aula. Tal reflexão é um passo fundamental para uma mudança de sua postura docente.

\begin{abstract}
(considerações de João sobre a participação dos alunos na atividade argumentativa) Eu acho que eles gostaram, eu achei. Isso aí é uma coisa que eu acho que vale destacar. Porque eles participaram da atividade argumentativa mesmo, que foi a produção do texto, e lógico, não foi o que a gente esperava, né, 100\%, mas pelo menos eles participaram e é uma coisa que eu achei que não aconteceria. Tanto a atividade argumentativa quanto a outra atividade a a exposição dos cartazes. (Fonte: Entrevista)

(consideraçães de João sobre a sua ação como docente) A minha postura eu achei que foi legal, com os alunos, eu pensei que fosse ficar mais nervoso, não fiquei. Sabe eu pensei que não conseguiria estimulá-los, isso que eu achei interessante que muitas vezes a gente sabe as coisas sabe passar só que eu acho que estimular o aluno também é legal. Eu acho que eu consegui fazer isso, mas tem muita coisa para melhorar também viu. (Fonte: Entrevista)
\end{abstract}

Em relação ao desenvolvimento da argumentação dos alunos, João apresenta que alguns não conseguiram entender a atividade, pois não seguiram uma ordem de raciocínio. Concluiu este aspecto, pois, os alunos apresentaram os pontos positivos e negativos da extração mineral, sem seguir uma ordem. Podemos identificar nesta justificativa (grifos nossos) do licenciando o SAD de Análise do Argumento, já que João apresentava os critérios que utilizou para afirmar a qualidade dos argumentos dos alunos.

(consideraçães de João sobre a sua ação como docente e a promoção da argumentação em sala de aula)... em relação à qualidade, eles confundiram muito na hora de expressar a opinião deles. Então, por exemplo, não seguiu muito uma, uma ordem, "ah, eu acho..." dos impactos ambientais, por exemplo, eles colocaram as coisas ruins e depois, mas também tem as coisas boas. Então. não seguiu muito uma ordem, eles meio que misturaram, assim.... "ah, tinha lá coisa ruim por causa disso e disso", depois ia para uma coisa boa depois

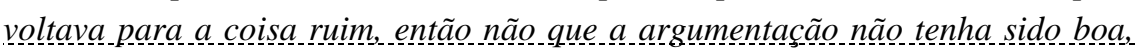
mas acho que como ela foi colocada. A estrutura dela. Então por isso que eu digo que foi mais ou menos né pela quantidade dos que argumentaram e pela estrutura que os que argumentaram, como eles colocaram. (Fonte: Entrevista)

Em relação a sua aprendizagem como docente, ao desenvolver uma regência com foco na argumentação, João aponta dois aspectos: o primeiro foi que achou que os alunos não iriam participar ativamente das atividades, no entanto, a participação 
foi efetiva demandando um pouco mais de tempo para serem desenvolvidas. Esse aprender do tempo é algo que se adquire na sala de aula, e em muitos casos, com um parceiro mais experiente. Além do aprender sobre o tempo percebemos, mais uma vez um entender do licenciando de que dependendo da ação do professor este tem a participação dos alunos em suas aulas. Tais aprendizagens podem ser classificadas num SAD Relativo às Estratégias, em que o licenciando aponta justificativa sobre o que aprendeu em relação a ações das estratégias docentes, como destacado na transcrição abaixo (grifos nossos).

Primeiro em relação à elaboração da regência, eu acho que, uma coisa que eu aprendi em relação ao tempo, né, você acha que vai dar uma aula então o que acontece... no meu caso, os alunos trabalharam mais até do que eu imaginei. Então o tempo excedeu: de três aulas foram para quatro aulas. (Fonte: Entrevista)

O segundo aspecto de aprendizagem diz respeito à própria concepção da atividade argumentativa e ao fato de poder ter um contato com uma metodologia diferenciada, já que mesmo na universidade o que predomina é um modelo tradicional de ensino. Nesse pensar, observa-se uma relação entre o SAD Relativo às Estratégias no qual o licenciando explicita os motivos de escolher determinadas estratégias em detrimento a outras, analisando cada escolha e sua relativa consequência num âmbito do processo educativo, indicando a necessidade de se analisar cada ação.

\footnotetext{
(em relação à aplicação da regência) Acho que a própria atividade argumentativa, assim, como é que eu posso te dizer? Deixe-me pensar aqui... eu aprendi a trabalhar essa, com a atividade argumentativa, tá, é uma coisa que eu não saberia fazer ... Então eu aprendi a fazer esse tipo de atividade, sair um pouco do tradicional e apresentar isso, e trazer isso pra sala de aula eu acho que isso aí vai me ajudar muito como professor. Por quê? Trabalhar com PowerPoint querendo ou não eu trabalhei aqui quatro anos né (se referindo ao período de graduação). Então isso aí se você apresenta como eu apresentei no primeiro dia re realmente para dar uma margem uma segurança. Só que trabalhar em sala de aula com giz lousa e você leva uma cartolina e conseguir atingir certo objetivo acho que isso é muito difícil. E isso eu aprendi, essa estratégia eu achei que vai valer muito a pena a que eu vou levar isso aí comoprofessor. (Fonte: Entrevista)
}

Além disso, para João o docente que deseja desenvolver uma atividade argumentativa necessita ter os conceitos de argumentação bem definidos e conhecer os elementos que definem um argumento. Em seu ponto de vista é fundamental 
também que o professor ao desenvolver qualquer tipo de atividade tenha claro o que pretende do aluno e valorize cada etapa de desenvolvimento do mesmo. Em especial, para que professores possam trabalhar com atividades argumentativas é importante abordar o conceito de argumentação com os próprios alunos. Obteve-se também que o licenciando apresenta mais uma vez os motivos da escolha da estratégia, em que considera a importância do professor ter claro o que deseja do aluno frente às atividades e saber conduzir a atividade de maneira a motivar os alunos.

(considerações de João em relação aos aspectos a serem considerados no desenvolvimento de atividade argumentativa) Então vocês viram quando agente fala em apresentação (se referindo à apresentação dos alunos) também a gente pensa que é assim né, que eles vão chegar lá, não porque é uma coisa assim. Foi o que eu falei é a mudança que a gente também tem que ter de saber o que eles vão querer. Porque, para levantar, para ir lá, ler o que estava escrito, o título. Então eu falei para eles olha o mais difícil era deles terem achado no texto e grifado, você tem que selecionar, então eles grifaram um monte de coisas depois eles grifaram o que selecionaram, para colocar no cartaz. Então acho que o. mais difícil eles conseguiram fazer que foi o cartaz. E apresentar depois que teoricamente seria mais fácil, que eu falei não só lê o cartaz o que colocarame e. porque, foi uma guerra foi uma luta ... Eu participei muito da apresentação, eles falavam lá mas eu explicava também para depois na aula de hoje eles tiveram que produzir o texto. (Fonte: Vídeo- Aula Prática do Ensino de Química)

Além disso, João destaca a importância de discutir com os alunos os elementos que compõem um argumento, explicitando um SAD de Conhecer os Elementos do Argumento. Neste aspecto, o licenciando justifica que se os alunos souberem o que é argumentação poderão trabalhar de forma mais efetiva nas atividades.

(considerações de João sobre os saberes necessários a um professor para desenvolver uma atividade argumentativa) Acho que ele tem que ter o que é uma argumentação bem definido. O conceito de argumentação, acho que isso aí.: sabe não precisa saber o passo a passo, lá, isso não precisa saber que a argumentação é... o argumento você tem lá o dado das coisas tem que ter também a conclusão, né você tem que ter essa estrutura bem definida na sua cabeça, ... e tem que saber que você tem que cobrar do aluno também né. Por que... o que acontece? A gente vai com um pensamento foi o que eu falei: você tem lá bem definido o que é argumentação na sua cabeça só que o aluno nó no vai saber direito.... Uma coisa que eu faria também na minha regência, se eu tivesse lá umas duas aulas, antes trabalharia com eles o conceito de argumentação. "Olha gente, argumentação é isso, isso, isso e acabou”. Para quêe? Para que na hora que eles fossem fazer a atividade né... Aí o que acontece? Você leva depois para eles como é que funciona certinho e isso eu acho que também daria para terfeito. (Fonte: Entrevista) 
João confirma em sua própria experiência os aspectos acima mencionados, afirma que ter um espaço de discussão nas aulas da disciplina de Prática do Ensino foi fundamental para seu entendimento sobre argumentação e o desenvolvimento de sua regência, expressando um SAD de Reflexão, em que explícita que os momentos de discussão são fundamentais para a aprendizagem da docência.

(considerações de João sobre as atividades desenvolvidas na disciplina de PEQ) Eu acho que o ponto da discussão que a gente fazia com você (pesquisadora), com a professora (docente da disciplina) e os alunos (demais licenciandos), eu acho que isso foi o ponto alto da nossa disciplina, ainda mais para a atividade argumentativa. Por quê? Foi o que falei, muitas vezes a gente argumenta, tem o raciocínio só que eu não tinha muita base teórica da coisa, né. Então o que acontece chegava lá se você pegar - tem até a filmagem - se você pegar a primeira aula que a gente discutiu um tema e pegar a última aula você vai ver uma evolucão. Exatamente, né, por estar discutindo sempre e ter a base teórica disso. Então eu acho que isso foi um ponto principal e que eu adorei também. (Fonte: Entrevista)

Em relação à reflexão sobre sua regência com foco na argumentação, o licenciando inicialmente apresenta que modificaria suas aulas, dando menos ênfase ao uso do recurso audiovisual e acrescentando experimentos, caso tivesse tempo hábil. Ao ter que assistir suas aulas pode ter outro "olhar" de sua regência, e o compartilhamento com seus colegas trouxeram novas visões e principalmente a oportunidade de ter um momento de crescimento com a ajuda de todos. Percebe-se o papel fundamental que o licenciando atribuiu ao momento em que teve que refletir e compartilhar suas ações com seus colegas, o qual ocorreu numa vertente de crescimento mútuo. $\mathrm{Na}$ transcrição abaixo podemos identificar o SAD da Aprendizagem Compartilhada, em que o licenciando aponta a importância de se ter momentos de reflexões conjuntas para seu crescimento como docente.

(considerações de João sobre os momentos de reflexão realizados durante a disciplina) Isso é importantíssimo. Nossa, é... porque é o seguinte: você said da sala às vezes você acha que deu uma péssima aula às vezes você acha que deu uma ótima aula. Só que o que acontece? Você se vendo, dando aula á uma coisa que muda sua concepção total. Aí você se vendo, você ter que pegar trechos e. apresentar para outras pessoas, pegar pontos positivos e negativos, isso te dá uma margem para autocrítica, tá, que é poderosa, que mexe né, com o brainstorm lá, sabe, dá uma chacoalhada na cabeça, então isso aí eu acho que é muito importante, isso aí tem que ter, tem que ter mesmo, todo o ano, e outra: além de você se autoavaliar, as pessoas estão te avaliando ali e você sabe que não tão te avaliando ... para te jogar para baixo. Não, estão te avaliando de uma forma crítica para você crescescer. (Fonte: Entrevista) 
Para João, o desenvolvimento de atividades argumentativas muda a visão do professor, de maneira que deixa de ver o aluno como uma "tábula rasa" para ser um sujeito ativo no processo de ensino-aprendizagem, assumindo uma atitude mais crítica em sala de aula.

(considerações de João sobre os benefícios das atividades argumentativas em sala de aula) Ele (aluno) para de ser aquela tábula rasa que a gente não considera. Ele começa a ser um agente mais crítico, ele consegue agir mais sobre a realidade dele, isso eu acho muito importante para o aluno. Ainda mais no Ensino Fundamental e Médio. Que ele está meio perdido não sabe muito o que quer. Então você trabalhando isso, ele consegue até formar uma personalidade dele, eu acho muito importante isso aí. (Fonte: Entrevista)

Além disso, João considera que as atividades de natureza argumentativa devem ser desenvolvidas já nas séries iniciais e perpassar até o Ensino Superior. Desta forma o aluno será preparado, sem ficar com receio de argumentar e o professor apto a desenvolver tais atividades. Para o licenciando, a falta de ações como essa acaba por gerar dificuldades em trabalhar com esta vertente em sala de aula.

\footnotetext{
(considerações de João sobre a dificuldade dos alunos em argumentarem) De prática deles (se referindo aos alunos), que não tem isso nunca, né. Não só deles como da gente aqui da universidade, sabe. Eles não têm isso nunca, não sabem o que é, então se você insere desde as primeiras séries, das séries iniciais, quando você está lá no terceiro ano, no primeiro ano do Ensino Médio, eu acho que isso fica muito mais fácil. Então o que acontece? Eu acho que é o medo do novo. Você chega lá no terceiro colegial e você não sabe o que é uma argumentação, né, você fica com medo de fazer. (Fonte: Entrevista)
}

Em uma análise geral de sua regência, João destaca dois momentos. No primeiro relata que havia preparado uma atividade com perguntas em que os alunos deveriam responder em uma folha. No entanto, como a aula estava sendo realizada na sala de vídeo, os alunos não levaram caderno, o que em um momento deixou o licenciando sem saber como agir. Nesta situação a professora de Química da escola básica, interviu na aula do João sugerindo a ele solicitar aos alunos responderem oralmente as questões. Diante desta vivencia, João destaca a importância do professor saber contornar os imprevistos ocorridos em sala de aula.

(considerações de João sobre imprevistos ocorridos em sala de aula) Uma coisa que eu achei interessante foi assim. Eu preparei cinco questões que eram da aula para eles responderem, mas como todo mundo foi para a sala de vídeo, ninguém levou caneta e papel. Ai eu falei tragam a semana que vem. Ai a 
professora (de Química da escola) estava do lado e falou: João não dá para responder oralmente? Pronto, era uma coisa que eu não tinha pensado e ela me ajudou. Ai eu pensei é importante termos essa manha, de não deu certo uma coisa sair rápido. (Fonte: Vídeo aula Prática do Ensino de Química)

No segundo momento, João apresenta a evolução de seus alunos na participação em sala de aula. Destaca que na primeira aula quando pediu que respondessem oralmente a diferença entre transformação física e química, teve um pouco de dificuldade na participação dos mesmos. No entanto, no decorrer da sequência de ensino conseguiu a participação ativa dos alunos.

(João reproduzindo cenas ocorridas em sala de aula) João: André (aluno) responde: Não tenho vergonha André vamos lá responde: Não tenho vergonha. Ai eu falei e ai pessoal vamos lá. Ai uma menina pegou e falou não, transformação química é isso e não sei o que. Ai eu disse legal. E transformação física é aquilo. Então a turma estava meio parada... A turma era difícil mesmo de trabalhar e esse foi o primeiro dia, eles não me conheciam direito, conheciam de eu ficar sentado, mas eu nunca tinha conversado com ele, então teve certa resistência. (Fonte: Vídeo aula Prática do Ensino de Química)

(considerações de João sobre sua impressão da turma) Eles tinham que pegar o texto grifar o que eles achavam que era impacto ambiental e o outro grupo o que era benefício e colocar na cartolina e ir lá apresentar. Agora você me fala como eu ia fazer com uma sala animada desta que eles apresentassem lá na frente? (risos) Mas ai no final a gente conseguiu fazer... (Fonte: Vídeo aula Prática do Ensino de Química)

João dá destaque a um aluno, que inicialmente não queria participar das atividades. João relata sua atitude frente ao desinteresse inicial do aluno e suas inserções no grupo de alunos para que se interessasse em participar da atividade. Além disso, expressa o seu aprender em ter que dar aos alunos um período de adaptação para que participasse das atividades, configurando em um SAD Relativo às Estratégias, pois indica a importância de considerar o tempo de adaptação aos alunos frente às atividades.

(João reproduzindo cenas ocorridas em sala de aula) Na segunda aula em que iam fazer o cartaz ele (aluno) chegou atrasado, ele chegou e puxou uma cadeira para sentar no outro grupo. Ai eu falei olha não pode, você tem que sentar neste grupo. "Não esse grupo é dos pior" (aluno). Eu falei chegou atrasado vai sentar nesse grupo. Ai ele sentou, e fez assim oh (bocejou alto). E eu quieto. Não e eu que quieto. Ai passei de grupo em grupo e fui no deles e falei: $E$ ai vocês não vão fazer nada? "Ah a gente não sabe”. Como não sabe? Vocês não sabem ler? Ah falei, fui meio rígido também. Ai ele disse "Não porque não sei o que". Ai eu disse ah você não sabe desenhar? Porque ele estava desenhando um dia. Ele 
estava desenhando umas letras e disse faz o cartaz. Ai começaram devagar, devagar, mas foi. (Fonte: Vídeo aula Prática do Ensino de Química)

Vocês viram porque eu coloquei o comeco da primeira aula?. (se dirigindo aos envolvidos na aula de reflexão da regência ocorrido na disciplina) Só parara mostrar que na primeira aula eu perguntei para eles a galera não respondeu. Nessa dai (se referindo à atividade do cartaz), na segunda aula eles já participaram e na terceira também. Vi que é necessário um período de adaptação aos alunos para que participem. (Fonte: Vídeo aula Prática do Ensino de Química)

Em sua futura atuação como docente, João apresenta que desenvolver a regência com foco na argumentação contribuiu para ter uma experiência diferenciada no processo de ensino. Além disso, destaca que esta vivencia colaborou para que ao atuar futuramente como professor já tenha uma segurança em desenvolver atividades desta natureza. O licenciando dá um destaque especial de ter tido no estágio a oportunidade de desenvolver uma atividade de natureza argumentativa, a qual considera como um momento ímpar na sua futura atuação docente.

(considerações de João em desenvolver uma regência com foco na argumentação)... Acho que me deu uma experiência de saber fazer uma atividade diferenciada em sala de aula, uma segurança também, porque eu acho. que muito do que o bicho vai pegar agora quando comecar a dar aula vai ser a inexperiência a insegurança. Então você ter trabalhado isso já antes no estágio, eu acho que vai dar uma seguranca para você fazer mais a vontade isso. Por que qual que é o problema? Você assume uma aula lá e vai trabalhar e não dá certo da primeira vez, então você fala "caramba", acho que te corta e você nunca mais vai fazer isso, né. Mas como você fez estágio então você viu tem coisa que dá certo tem coisa que dá errado. Próxima vez que eu for fazer isso já vou ter as coisas certas, vou tentar corrigir algumas outras coisas, então eu acho que isso aí foi muito bom. (Fonte: Entrevista)

Refletindo sobre a metodologia que utilizou, João concluiu que o uso do recurso audiovisual forneceu uma maior segurança e possibilitou por meio de vídeos e imagens aproximar os alunos da realidade do tema. No entanto, considera que se refizesse a regência usaria também experimentos, em que trabalharia de outra forma os conceitos químicos.

Foi bom pela segurança, para eu me sentir seguro porque o Power Point te dá uma segurança, mas eu acho que eu mudaria (numa nova oportunidade de regência) tentaria fazer alguma dinâmica. Eu traria também alguns, se tivesse mais tempo, né, lógico, algum tipo de experimento que eu acho legal. (Fonte: Entrevista) 
João declara-se totalmente satisfeito com sua regência, apresenta aspectos que poderiam ser modificados, e sente que superou suas expectativas, tanto em sua capacidade de desenvolver uma atividade com uma vertente argumentativa como com a participação dos alunos.

(considerações de João sobre a potencialidade da atividade argumentativa) A primeira aula foi uma aula tradicional, a segunda aula, que eu acho que eles aprenderam mais, que foi na construção dos cartazes, tá, que eles não aprenderam só do conteúdo mas também eles se soltaram mais. Só que eu acho que deveria ter tido mais tempo para fazer essa aula, por quê? Porque eles chegaram na atividade argumentativa n não estava muito forte, fixo os conceitos, tá. (Fonte: Entrevista)

Mas sinceramente, eu gostei, gostei mesmo. Até no final eu agradeci eles e disse que não esperava a recepção que eles tiveram. (Fonte: Entrevista)

Da ação do licenciando durante sua regência pudemos identificar algumas situações consideradas potencialmente significativas à promoção de um ambiente favorável a argumentação dos alunos do Ensino Médio.

(apresentação do cartaz dos alunos do grupo 2 na escola de Educação Básica) João: Isso, oh também cai naquele mesmo tema que os meninos colocaram também, a aplicação dos minerais no cotidiano. No deles, eles (se referindo a apresentação do outro grupo) colocaram mais das aplicações do cotidiano, que a gente usa mais, vocês colocaram mais para a indústria ... oh o que eles estão falando aqui, também da importância histórica que a partir da revolução industrial teve intensificação desta atividade. (Fonte: Vídeo Regência na Escola de Educação Básica)

(apresentação cartaz do grupo 4) João: pessoal oh queria levantar dois pontos que eu achei bem legal. Por mais que estamos com dois temas a abordagem foi um pouco diferente cada um falou de uma coisa. Eles (grupo 3) falaram mais dos impactos da natureza, ... e o que que é legal aqui (se referindo a apresentação do grupo 4) eles colocaram o porque, o porque que tem esta extração. Então o crescimento populacional, com a demanda de recursos que a gente precisou, precisou aumentar a extração desses minerais. Então quanto mais consumista a sociedade é, mais minerais a sociedade irá precisar... (Fonte: Vídeo Regência na Escola de Educação Básica)

Então o que ela colocou (se referindo a aluna do grupo 4) ... afeta a flora, afeta a fauna também não é só a flora contaminação das águas que o grupo da Fernanda (grupo 3) também colocou. E aqui? E para a gente frear isso ai? Isso é uma reflexão que o autor faz no texto (entregue aos alunos para a elaboração dos cartazes), este texto eu peguei do portal do MEC, do portal do professor. Se agente quiser diminuir este impacto temos que repensar o nosso modelo industrial e nosso modelo de vida também. (Fonte: Vídeo Regência na Escola de Educação Básica) 
Identificamos nas gravações das aulas de João outro momento da regência em que poderíamos detectar um esforço do licenciando em promover um ambiente argumentativo em sala de aula, observado nas transcrições abaixo. Percebemos que João conduz a aula de maneira que os alunos não somente apresentem suas conclusões, mas também justificativas que as embasem. Tal busca ocorreu na atividade planejada pelo licenciando para promover a argumentação dos alunos.

(João fazendo a leitura da atividade aos alunos) João: Imagine a seguinte situação: você mora na região do Pantanal desde que nasceu e essa região está sofrendo uma série de transformações ambientais e sociais, uma delas está relacionada à instalação de uma grande empresa metalúrgica. Ninguém sabe ao certo quais os impactos destas atividades ao meio ambiente, você está inconformado com a situação. Por isso decide escrever uma carta ao técnico do escritório regional do Instituto Brasileiro de Meio Ambiente e Recursos Renováveis situado em sua cidade. (Fonte: Vídeo Regência na Escola de Educação Básica)

(explicação do João em relação à atividade) João: Então o que acontece você mora nessa região e instalou uma empresa de metalurgia que vai extrair ferro e cobre desta região. Você quer algumas explicações, você quer saber quais são os impactos que isto pode causar. E você vai escrever isso para o cara lá do IBAMA. (Fonte: Vídeo Regência na Escola de Educação Básica)

(leitura da atividade) João: Você deve nesta carta demonstrar sua preocupação, argumentar em relação aos impactos sociais e ambientais que podem ser provocados pela ação dessa empresa, utilizando seu conhecimento sobre a atividade mineradora e solicitar providencias quanto a elaboração de um estudo e de um relatório em relação a estas atividades. (Fonte: Vídeo Regência na Escola de Educação Básica)

(explicação do João em relação à atividade) João: Então vocês vão te que pegar tudo o que nos vimos sobre o vídeo, sobre a aula que eu dei, o que vocês escreveram nos cartazes, que eu coloquei aqui também para direcionar, e colocar para a pessoa. Sei lá, olá meu nome é tal, ta acontecendo isso na minha região, e pelo que eu sei, essa atividade, dar um exemplo, acontece isso e isso com o meu ambiente, eu queria saber o que vocês vão fazer? ... O que devemos fazer agora, colocar para a pessoa tudo o que a gente que deve fazer e o que a gente sabe sobre esta atividade. Ok? (Fonte: Vídeo Regência na Escola de Educação Básica)

Percebemos que João nos diferentes momentos de sua regência procurou direcionar as atividades para que os alunos relacionassem o conteúdo científico aprendido em sala de aula com um problema do seu cotidiano e que tomassem uma atitude numa perspectiva de cidadão crítico. 


\section{Licencianda Marta}

Marta tinha como temática o impacto da extração mineral na sociedade, a qual seria analisada na perspectiva de uma visão socioambiental. A regência estava voltada a alunos do primeiro ano do Ensino Médio. A licencianda optou por abordar as transformações que ocorrem com a matéria bruta até o produto final, levando-se em conta os produtos intermediários. Marta discutiu em suas aulas os impactos gerados pelo setor extrativista e industrial. Como metodologia de ensino nas duas primeiras aulas a licencianda fez uma apresentação em PowerPoint e nas seguintes desenvolveu uma atividade que, em sua concepção, promoveria a argumentação dos alunos (Quadro 24).

A atividade consistia em entregar, a dois grupos distintos de alunos, textos em que seriam destacados os aspectos positivos e negativos da mineração. Após a leitura os alunos tinham que elencar, individualmente e depois em pares, os aspectos mais significativos do texto. Em seguida, alguns integrantes dos grupos foram trocados de grupo de maneira que em uma mesma equipe ficassem alunos que continham textos com aspectos positivos e negativos.

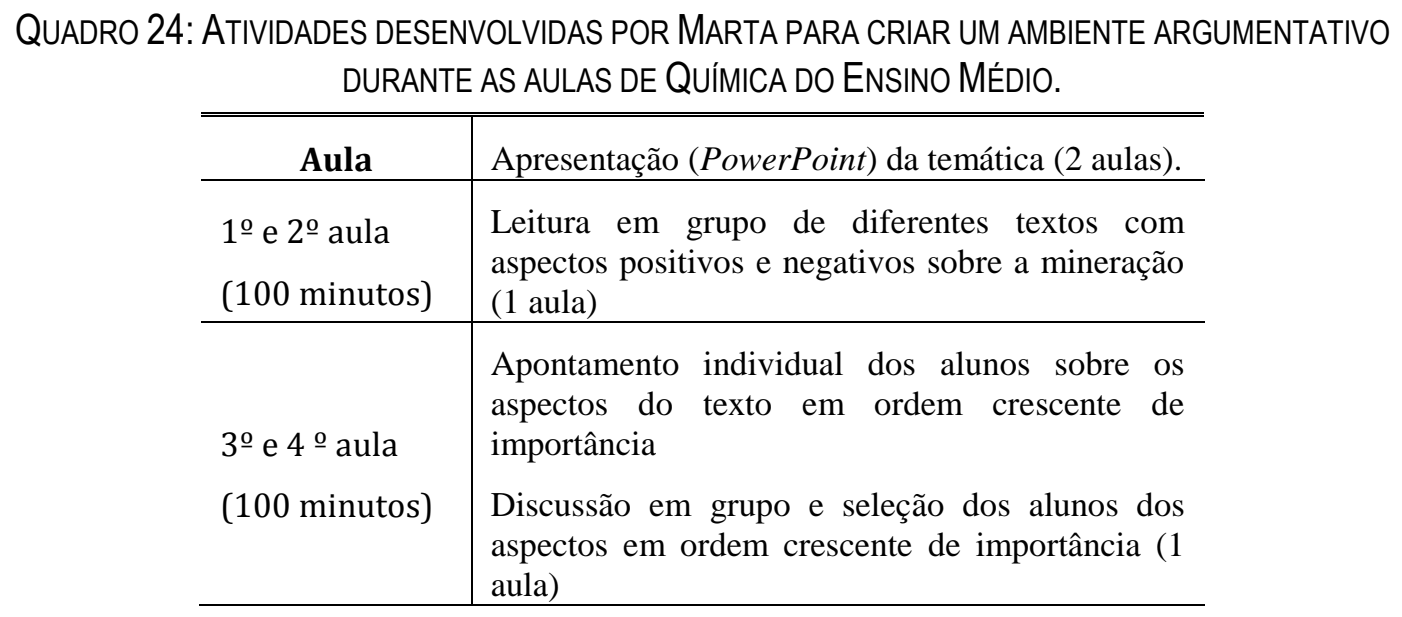

Marta relata que, antes de definir a atividade argumentativa, havia pensado em outras como um jogo de interpretação de papéis. No entanto, ao considerar o tempo necessário à realização da atividade e também as características dos alunos, optou por realizar um debate. Inicialmente havia realizado uma pesquisa de texto em fontes bibliográficas como o site SCIELO e a revista Veja, além de buscar 
propaganda de mineradoras como a Vale do Rio Doce. Porém, durante a apresentação de seu projeto de regência na disciplina de Prática do Ensino de Química percebeu que os textos se constituíam em materiais extensos, o que possivelmente não atrairia o interesse dos alunos por sua leitura. Assim, Marta optou por fazer recortes dos textos deixando-os mais sucintos.

Observamos a explicitação de Marta de dois saberes que possuem forte relação. O primeiro diz respeito, à escolha de estratégias que mais se adequavam ao público com o qual desenvolveu sua regência, sendo o SAD Relativo às Estratégias. Identificamos que Marta justifica o que a levou a escolher a estratégia utilizada e a importância de relacionar a metodologia com seu público alvo.

O segundo saber é o SAD de Gerenciar Ideias Instigando Questionamentos, pois Marta justifica que a escolha da estratégia estava vinculada ao objetivo de criar um ambiente em que os alunos pudessem apresentar suas ideias sobre o assunto abordado. Além disso, que pudessem justificar seus posicionamentos, o que considera que poderia conseguir com o uso de uma atividade em que os alunos teriam que em conjunto chegar a conclusões para posicionar em ordem crescente de importância os conceitos concernentes a extração mineral.

(Marta relatando o processo de escolha da estratégia argumentativa a ser utilizada em sala de aula) Como eu fiz inicialmente, eu tinha pensado em fazer um jogo. Eu tinha construído um jogo de interpretação de papéis. Só que aí eu pensei que de uma a três aulas ia ser muito pouco para eu desenvolver isso, porque eu queria que eles trabalhassem com a parte o impacto social dentro desse jogo. É, a parte social, Saúde, essa parte. Aí eu parei pra pensar "Eles não vão ler a caracterização dos personagens. Eles não vão entrar no espírito da coisa". Fiquei assim, pensando, pensando, pensando aí.. um mês de trabalho, foi para a cestinha. Aí eu pensei "Já que é uma atividade argumentativa, vamos debater vamos abrir um debate e criar um ambiente em que eles possam discutir várias informacões". Ai eu pensei nos textos. Eu separei texto pelo Scielo uns 4, 5 artigos. peguei recorte da Veja recorte da Época e recorte de tudo e mais um pouco, panfletagem da Vale de tudo. Aí chegou na aula,o.Tales disse “Eles não vão ler!”. Aí a professora disse "Eles não vão ler". Beleza, né, tem que fazer um picote. Aí o Pedro já tinha feito aquele texto que ele tinha falado da atividade dele em fazer recortes e usar a discussão da afirmação se era verdadeiro ou falso, aí eu pensei... Fiquei matutando, matutando enquanto o resto de pessoal falava ... (Fonte: Vídeo- Aula Prática do Ensino de Química)

Eu tentei fazer aquele método referencial: metade do grupo recebeu informações positivas, metade recebeu negativas, ranquearam inicialmente, individualmente os tópicos, depois em um grupo, entre pares e depois, em grupos com membros 
com informações contraditórias. (Fonte: Vídeo- Aula Prática do Ensino de Química)

(Marta relatando como foi conduzida a dinâmica da atividade argumentativa) Está é a última aula em que teve um debate aberto, eles já tinham feito esta atividade (mostra a folha com as instruções da atividade). Na frente eu queria a opinião dele, baseado nestes trechos (vira a folha e mostra os trechos) eu montei grupos com opiniões iguais e depois com opiniões diversas ... Tinha duas folhas com coisas boas e coisas ruins, só que os alunos não sabiam. A ideia é que eles conseguissem fazer uma lista geral que fosse igual para todo mundo e o grupo dois com as coisas diversas. E uma outra que era ofechamento do motivo dessas duas colunas (se referindo à terceira coluna da folha). (Fonte: Vídeo- Aula Prática do Ensino de Química)

Marta considerou também entre os aspectos para desenvolver a atividade, que os alunos não se sentissem pressionados a receber uma nota, de maneira a estarem mais a vontade em participarem. No entanto, os alunos ainda mantinham a ideia de qualificação por meio de menção.

Eu queria uma atividade em que eles não se sentissem pressionados a receber uma nota. Porque quando você fala "Ah, vocês vão dissertar pra mim, vocês vão produzir um texto", quer dizer que o texto vai ser corrigido. A própria atividade de argumentação, ahn, a própria atividade do referencial, as crianças, quando eu entreguei de volta eles perguntaram "Você corrigiu?". "Não. Não era esse o intuito". (Fonte: Entrevista)

Em relação às dificuldades e/ou facilidades que Marta teve no desenvolvimento de sua regência, a licencianda diz que sua primeira dificuldade está vinculada ao fato de que imaginava que as regências seriam desenvolvidas em um formato padrão, em que utilizaria um método tradicional de Ensino. No entanto, ao receber a orientação de que precisava desenvolver uma aula numa perspectiva de promover a argumentação dos alunos e ainda ser num tema escolhido pela professora de Química da escola, sentiu que teria relativa dificuldade para desenvolvê-la.

Marta elenca alguns aspectos da referida dificuldade, como sua falta de experiência, sua dificuldade em comunicar-se com os alunos, já que possui uma diferença de idade que considera significativa, e o fato de ter que desenvolver uma atividade que fosse agradável para os alunos. Vemos uma explicitação da licencianda de uma reflexão que tange ao desenvolvimento da regência em diferentes âmbitos, desde o momento que se depara com a necessidade de desenvolver uma regência numa perspectiva argumentativa, o que vai totalmente de encontro ao que esperava 
desenvolver em sua regência, até o momento em que esta inquietação a faz procurar atividades que realmente fossem efetivas e agradáveis aos alunos.

(considerações de Marta sobre sua impressão em desenvolver uma regência de natureza argumentativa) Inicialmente eu achei que a nossa regência ia ser aquela aula de Química redondinha, bonitinha, a gente pega o tema, desenvolve, vê no fim se todo o mundo consegue replicar, se todo o mundo balanceou as equações direitinho... Aí veio a atividade de argumentação. Aí você pensa "Meu Deus do céu, uma atividade de argumentação em Química. Meu Deus, Química! O que eu vou fazer?". E o pior, dentro do tópico que a professora escolher... (Fonte: Entrevista)

Eu me senti um peixe fora d'água! Até porque, a minha diferença de idade para eles, para os alunos, é, eu os vejo atualmente como crianças! É, é extremamente difícil pensar em como eles pensam. Então eu pensava atividade de argumentação, alunos, criança querendo fazer alguma coisa diferente. E eu pensando "Tem que ser alguma coisa agradável, porque 4 aulas com uma pessoa que você não conhece, aguentando a pessoa falando o tempo todo, tem que ser alguma coisa agradável" e mesmo assim acho que não foi 100\%. (Fonte: Entrevista)

Ainda em relação às dificuldades enfrentadas a licencianda aponta a falta de hábito de leitura dos alunos, pois mesmo tralhando com texto em um formato mais reduzido alguns alunos não o leram. Identificou também uma falta de interesse, por parte da maioria dos alunos, em relação à atividade, pois alguns deixavam transparecer que por ser a última aula estavam interessados em irem embora para casa.

\begin{abstract}
(Marta relatando suas dificuldades na implementação da atividade argumentativa) Primeiro, quando eu descobri que eles não iam ler, então essa foi uma dificuldade. É uma característica desse grupo etário. Eles não gostarem de ler também dificulta bastante. É... a falta de atenção muitas vezes. Às vezes eles perguntavam alguma coisa, eu começava a responder e tchum! Esqueciamse do assunto. É, a ausência de foco, por assim dizer. (Fonte: Entrevista)

Quando você entrega uma folha com letras nela, eles já olham para a sua cara e dizem "Dona, sério? Tem que ler?". Gente, eu leio um livro por mês! Aquelas crianças precisam ler mais! Precisam criar o hábito de ler. Então elas já têm aquela resistência: "peraê, eu tenho que ler alguma coisa". Eu tenho uma resistência a estar, muitas vezes, lá. Alguns têm. E aí, você olha as estratégias, assim alguns têm vergonha (se referindo aos alunos lerem em sala de aula). (Fonte: Entrevista)
\end{abstract}

Marta, em seu depoimento demostra grande frustração com sua atuação docente, já que em muitos momentos não conseguiu obter a participação dos alunos. Além disso, não conseguiu fazer com que os alunos percebessem o motivo de 
aprender, que pudessem perceber o quanto a educação independente da classe social e que pode trazer benefícios às pessoas. Marta mostra-se em muitos momentos decepcionada com os alunos, pois compara as condições que teve na sua formação básica e acredita que eles deveriam empenhar-se mais em estudar.

(reflexão da licencianda sobre sua regência) Olha... Eu preparei tudo, olhei tudo, como eu preparei a aula 1 e a aula 2, que eram apresentações, tá bem produtivo ... é, do ferro e do cobre, eu achei que ficou bom. "Olha, tá redondinho, tudo que tem de Química, do assunto tá aqui, tá redondinho". Lembrei, é, eu lembrava pra erguer um monte de fatos, que podiam ser inseridos, se desse tempo porque... Mas toda a vez que eu saia, todas as aulas eu tinha aquela sensação "Nossa, que aula chocha! Coisinha sem vergonha". (Fonte: Entrevista)

[...] Porque eu tinha, o que?, feedback de 2, 3 alunos, então isso me fazia sentir assim "Tem alguma coisa que eu não sei fazer direito. Tem alguma coisa que tá muito, muito errada aqui”. É, nessas últimas duas aulas, foi uma sensação assim "Eu estou tentando fazer eles fazerem alguma coisa pra mim, e a única coisa que eles fazem é falar 'Ô tia! Ô dona! 11:30h! Dona, meio-dia, a gente tem que ir pra casa!". Então dá aquela sensação de extremo desconforto e ao mesmo tempo uma frustração por não estar fazendo a aula interessante. (Fonte: Entrevista)

(considerações de Marta sobre os motivos de seu insucesso) É, o foco, acho que o motivo disso é porque eu queria que eles aprendessem, eu queria que eles se divertissem aprendendo porque, eu lembro das minhas aulas, eu lembro que eu era uma criança interessada, eu era uma aluna interessada ... acho que, foi no $1^{\circ}$ ou no $2^{\circ}$ que eu tava indo, que eu não lembro qual era. "Tia, pra que estudar? se vai virar caixa de supermercado" e eu olhando assim, aquilo me dava um nervoso porque, gente, minha mãe é cabeleireira, meu pai é mecânico, eu morava na beira de uma favela em São Paulo, ai que raiva! O tanto que a gente teve que vir pra chegar onde eu tô agora, e assim, um monte de criança me diz uma coisa dessa! Aí não presta atenção, é aquela coisa, eu não consegui chamar a atenção, eu não consegui fazer alguma coisa por elas. Aí fica a frustração. (Fonte: Entrevista)

No entanto, Marta destaca que em determinados momentos houve a participação dos alunos nas aulas, em que até mesmo assuntos correlatos e distintos da temática da aula eram suscitados.

Alguns alunos perguntaram bastante, queriam saber mais, é... a gente chegou a tópicos, assim, até bastante distantes do que a gente estava. As perguntas tangenciavam o assunto da aula, muitas vezes. E algumas vezes depois da aula eles perguntavam alguma coisa, em geral o Gabriel e o Lucas, que era aquela duplazinha, que a gente ia para assuntos que tangenciavam, às vezes se distanciavam bastante. (Fonte: Entrevista) 
A licencianda tinha a concepção de que o desenvolvimento da atividade argumentativa poderia ampliar a visão dos alunos de que um determinado assunto pode ser analisado, de diferentes perspectivas, com fortes influências em nossa sociedade. Além disso, esperava que os alunos percebessem a Química como algo integrador e que pode ser usada como fonte para diferentes discussões relacionadas diretamente à vida dos alunos. Porém, em sua análise Marta acredita que de uma maneira bem comedida, conseguiu que os alunos vissem um algo a mais da Química, não somente o que eles têm acesso na lousa e giz.

(considerações de Marta em relação à função da atividade argumentativa na sua regência) Mostrar a eles (alunos) que um assunto tem que ser analisado por vários ângulos. Que um evento na nossa sociedade não é, não é estanque, e mostrar pra eles que o que eles acham que é um assunto, assim, ver na lousa escrito química não era só química, é muito mais coisa. Mostrar que se eles, com quatro pessoas (se referindo ao ranque dos conceitos) estavam tendo problemas, imagine numa equipe maior. Por isso o desenvolvimento muitas vezes atravancado. (Fonte: Entrevista)

Para Marta, um professor que deseja trabalhar a vertente argumentativa em suas aulas necessita ter um preparo aprofundado do conteúdo, pois o fato de abrir questionamentos possibilita o aparecimento de perguntas que não estão em um padrão esperado e ter conhecimentos das atividades que podem possibilitar um ambiente argumentativo e conhecer os elementos que constituem um argumento. Marta explicita a necessidade do professor ao trabalhar com atividades ter claro o conteúdo o qual irá atuar, pois os alunos possuem um arsenal de possibilidades para colocar o professor em situações que precisa usar do seu conhecimento científico para sanar as dúvidas.

(Marta se referindo ao conhecimento necessário de um professor para desenvolver atividades argumentativas) Preparo é essencial. Você vai ter que ler bastante dentro do tópico que você vai trabalhar porque os alunos assistem muita TV, conversam muito com as pessoas, leem fontes duvidosas de informação na internet, então você tem que estar pronto para as mais insanas possibilidades. Uma maneira de manter o foco dentro do assunto que está tratando porque eles começam a criar digressões durante as aulas, conhecer propriamente as estratégias argumentativas, procurar os artigos, procurar, é, a base para você trabalhar. Começar a argumentar mais, para poder desenvolver e conhecer exatamente como é o argumento, bonitinho, redondinho... (Fonte: Entrevista) 
Além disso, Marta apresenta como fundamental que o professor tenha noção das habilidades e necessidades que estão vinculadas às atividades argumentativas, a qual não se caracteriza como uma atividade de lousa e giz. Nesta perspectiva o aluno é visto como um sujeito que tem voz ativa no processo de ensino-aprendizagem. Marta também apresenta que conseguiu aprender a desenvolver habilidades de comunicação com os alunos, configurando em um SAD Relativo às Estratégias, conforme podemos observar na transcrição abaixo (grifos nossos), em que apresenta como teve que se portar no papel de docente para conduzir uma atividade de natureza argumentativa.

\footnotetext{
(considerações da licencianda sobre desenvolvimento de uma atividade argumentativa) Essa atividade de argumentação faz você precisar ter uma interação maior com o aluno, não é aquela coisa taxativa "Estou na lousa, você está aí sentadinho na sua carteira, fique quieto enquanto eu falo!". (por que??) Você tem que falar você tem que interagir, você tem que conversar, você tem que estabelecer os limites, então ser um professor, ou você desenvolve ali e comeca a jogar ou não tem o que fazer ... Então, como habilidades que eu consegui, seria dizer 100\%, é, traquejo. social dentro dos alunos, dentro daquele ambiente com alunos. (Fonte: Entrevista)
}

Marta também discorre que aprendeu ao longo do desenvolvimento da atividade de natureza argumentativa, saber escolher a estratégia, saber ver as possibilidades positivas e negativas atreladas a ela. Destaca também o aprendizado relativo a ouvir as sugestões dos colegas (se referindo a momentos em que compartilhou seu projeto de regência na disciplina de Prática do Ensino de Química), e de compartilhar sua experiência numa perspectiva construtiva do aprender a docência. Reflete neste contexto um SAD Relativo às Estratégias.

(em relação ao que a licencianda aprendeu durante a dinâmica ocorrida na disciplina) Aspectos que influenciam as estratégias que você escolhe é.... elaborar e enxergar corretamente quais são seus objetivos dentro da própria ação de construça ão das aulas. É, propriamente argumentar com os professores (se referindo aos colegas da disciplina) sobre o desenvolvimento e o que eu gostaria de fazer. E o que é factível. (Fonte: Entrevista)

Em relação a sua ação como docente, Marta considera que conseguiu criar um ambiente para que os alunos argumentassem, mesmo não tendo a adesão de todos. Além disso, buscou utilizar dos elementos dados pelos alunos, como no caso em que questiona aos alunos quais aspectos poderiam considerar na instalação de uma 
mineradora, neste episódio uma aluna respondeu que estava com fome, diante da resposta a licencianda envolve uma outra linguagem mais voltada a temática abordada, conforme observado na transcrição abaixo.

(Marta se referindo a sua ação em sala de aula) Tentei dar o máximo de liberdade para que eles pudessem argumentar e tentar virar um ambiente onde eles pudessem argumentar, desde grupos pequenos a grupos maiores... (Fonte: Vídeo- Aula Prática do Ensino de Química)

Quando eu perguntei que outros aspectos eles poderiam vir a analisar para a instalação de uma mineradora a aluna respondeu: alimento. Eu perguntei que foi? To com fome... Ai eu disse para ela vamos reescrever de um modo elegante, agricultura, geração de alimentos (risos). (Fonte: Vídeo- Aula Prática do Ensino de Química)

Marta também usou de estratégias que pudessem melhorar o entendimento dos alunos em relação ao tema, por exemplo, ao analisar as fichas com os conceitos percebeu que os alunos tinham colocado tecnologia em último lugar no ranque, então chamou um aluno (doravante denominado de Robson) e começou a questioná-lo de onde vinham os acessórios que estava utilizando.

(Marta relatando uma situação de sala de aula) Foi assim eu peguei o Robson de cobaia, porque todo mundo jogou tecnologia lá em baixo (se referindo à colocação dos alunos em relação aos termos)... o que eu queria fazer é que eles compreendessem que o estilo de vida deles tá ligado com os metais. Ai o que eu fiz, o que do estilo de vida deles tá ligado aos metais, ou que foi usado de metal para fazer, ou que dependeu do metal para ser feito... Ai eu tirei o boné, o colarzinho mostrando o uso dos metais nos materiais. (Fonte: Vídeo- Aula Prática do Ensino de Química)

Porque quando eu fui analisar, eu achei que tecnologia, desenvolvimento social, estava muito longe da realidade deles por isso que eles jogaram para baixo na escala deles... Ai eu fiz aquela brincadeira onde vocês estariam sentados se não tivessem descoberto fundição? Eu fiz este tipo de pergunta numa sequência. (Fonte: Vídeo- Aula Prática do Ensino de Química)

Marta apresenta que em muitos momentos instigou os alunos a justificarem seus posicionamentos em relação à escolha de prioridades dos conceitos da atividade. A licencianda percebeu ao longo das atividades que alguns alunos mudaram radicalmente seu posicionamento em relação à posição dos conceitos e tentou instigá-los a justificar a mudança de posicionamento. Em um dos casos identificou que, por não chegarem a um consenso, o grupo optou por uma votação. São esses 
momentos em que houve discussão que a licencianda identifica a argumentação por parte dos alunos.

(considerações de Marta em relação a sua ação) eu peguei as fichas que eles preencheram no terceiro dia de regência. Eu notei que houve certos alunos que tinham impressões muito díspares dos demais. Por isso na quarta aula, na aula de hoje, eu tentei cutucar exatamente estes alunos que estavam com as informações, que mudaram de opinião radicalmente. É aí, perguntei ao grupo, né, que formou a opinião no fim, é eles tinham uma opinião diferente e ao outro, porque ele se deixou convencer. Num dos grupos, no fim das contas acabou em votação, porque ele não descia do cavalo nem os outros subiam (risos), (Fonte: Vídeo- Aula Prática do Ensino de Química).

No entanto, neste mesmo episódio, narrado acima, Marta esbarrou com uma questão que envolve a concepção que os próprios alunos têm em relação aos seus colegas de classe. Isso porque a justificativa de uma aluna em não aceitar a ideia do colega era de que ele não era inteligente, optando então por uma votação no grupo para decidir a posição do conceito.

\begin{abstract}
(Marta relatando a cena em que solicita a justificativa dos alunos de não terem considerado a ideia do colega) São duas meninas e dois meninos, as meninas na feira de ciências fizeram tudo bonitinho... e os meninos um deles fala bastante é articulado, tem ideias, insights, o outro entende bem, responde bem, mas tem problemas de se articular. E eles fizeram uma discussão bastante longa durante a terceira aula... E eles discutiram e eu fiquei interessada mais por causa das fichas. Porque nesse grupo um dos alunos colocou tecnologia no topo da lista dele, e quando foi feito o grupo ele jogou para baixo e eu queria saber o porque, que argumentos levaram ele a concordar com esta situação. E ai o negócio degenerou, porque no fim das contas ele tentou convencer os outros, tentou argumentar, os outros não aceitaram os argumentos deles, no final das contas os quatros votaram. Ai quando eu perguntei para os três porque eles não tentaram ver de outra forma o tópico ou porque resolveram votar, uma das meninas a mais santinha disse é porque ele é burro. (Fonte: Vídeo- Aula Prática do Ensino de Química)
\end{abstract}

Marta ao analisar os argumentos dos alunos viu que eles nem sempre continham os seus elementos necessários, e que em muitos casos o problema podia estar vinculado também ao fato dos alunos não estarem acostumados a desenvolver atividades desta natureza. Conclusão compartilhada pelos seus colegas licenciandos durante o momento de reflexão da regência na disciplina.

A licencianda considera que de uma maneira comedida alguns alunos argumentaram, e que uma explicação para esta baixa incidência pode estar relacionada à falta de interação com os alunos. A licencianda considerou também 
como critério para a ocorrência da argumentação a modificação dos tópicos, mesmo que em um caso específico a alteração tenha decorrido de uma não concordância entre os integrantes do grupo, resultando em uma votação, como mencionado anteriormente.

(Marta analisando se os alunos argumentaram durante as atividades) De uma certa forma sim. Por mais que a forma como eles argumentaram não tenha sido como eu esperava. É, o desenvolvimento, a própria linguagem que eles usam, dificulta às vezes a interação entre eles. Sendo que alguns são bastante hostis ou simplesmente ignoram o fato de que está acontecendo alguma coisa. (Fonte: Entrevista)

A licencianda em determinado momento também mostra que em sua época de estudante do Ensino Médio, aprendeu nas aulas de português a argumentar, a fazer redação de natureza argumentativa e diz que tinha uma professora de português que trabalhava estes aspectos na oitava série. A aluna se questiona se os professores mudaram tanto. Durante a discussão, feita no momento de reflexão da regência, surgiu o comentário de que o próprio coordenador da escola em que o estágio foi realizado falou que os professores, em geral, limitam-se ao uso da lousa e giz.

Ainda no trecho abaixo, vemos uma explicitação por parte da licencianda dos elementos do argumento e do papel que cada um assume dentro do ambiente argumentativo, de maneira a levar a um SAD de Gerenciar Ideias Conhecendo os Elementos do Argumento, os quais identificamos os porquês implícitos nas colocações de Marta.

(discussão dos licenciandos durante atividade de reflexão da regência ocorrida na disciplina)

João: Não que os alunos não estão interessados, mas porque eles não estão acostumados a fazer este tipo de atividade.

Marta: Não, eu notei isso quando eu comecei a ouvir as explicações, é porque eu estava pensando naquele argumento bonitinho né. $O$ dado, a justificativa aqui (licencianda gesticula a posição dos elementos no esquema de Toulmin) A conclusão aqui, ai pensei tem o backing. Ai quando eu comecei a analisar cortei o backing, o qualificador modal (risos), cortei a refutação, principalmente na hora em que a refutação da outra foi você é burro... Isso eu coloquei no relatório os alunos não estão acostumados a fazer está comunicação verbal e metade disso eu culpo o twitter, com 140 caracteres como você argumenta? (risos)

João: Não é isso, eles não estão acostumados. 
(Fonte: Vídeo- Aula Prática do Ensino de Química)

Em relação à atividade desenvolvida, os colegas de Marta opinam que a atividade caracterizou-se como um pouco complicada, em que faltou uma maior clareza do que os alunos deveriam realmente realizar. Marta é favorável a essa conclusão e diz que se pudesse reapresentar a regência a modificaria de maneira que os aspectos positivos da mineração fossem também percebidos pelos alunos.

\section{(discussão dos licenciandos durante as atividades de reflexão da regência ocorrida na disciplina)}

Tales: Eu achei a aula extremamente complicada.

Rose: Eu acho que ficou pouco dinâmico e acho que não ficou tão claro para eles, por isso até que pode ter havido esse desinteresse.

Marta: ... A ideia final é que eles soubessem a dificuldade de colocar as prioridades, e desde o primeiro dia que eu falei para eles que para resolver um caso deste (discutindo sobre a atividade mineradora) você precisava de muitos profissionais, sim são muitas pessoas trabalhando para resolver o problema.

Professora: E com isso você quer dizer?

Marta: Definir as prioridades do projeto. E eu queria que eles entendessem o qual difícil é para eles chegarem a um consenso ...

Professora: Como você redesenharia a atividade?

Marta: Hummm de uma forma em que eles pudessem observar os pontos positivos da mineração.

(Fonte: Vídeo- Aula Prática do Ensino de Química)

Marta considera que as atividades desenvolvidas na disciplina de Prática do Ensino de Química foram fundamentais, para a sua compreensão da argumentação em sala de aula, desde um aspecto teórico até o prático na elaboração da atividade com sua posterior análise juntamente com os demais licenciandos. Marta mais uma vez considera o papel ímpar dos seus colegas no desenvolvimento da sua regência, de modo a vir a expressar a importância do trabalho em colaboração, configurando o SAD da Aprendizagem Compartilhada.

(considerações de Marta sobre as atividades desenvolvidas na disciplina de Prática do Ensino de Química) Olha, os textos, os artigos que a gente usou naquela atividade (se referindo a oficina de leitura sobre argumentação) forneceram um monte de pistas e um monte de ideias. Trocar ideias com os outros alunos (se referindo aos licenciandos) no dia que a gente estava 
montando, apresentando as regências, os projetos de regência e cada um dando uma ideia aí eu notei que eu não podia colocar textos para eles lerem. Com uma folha eles estavam reclamando no dia. Então foi ótimo me avisarem daquilo. É, eu acho eu achei mais fácil construir a atividade argumentativa com a ajuda dos demais, porque eu tenho uma linha de raciocínio mas a minha linha de raciocínio não é não cobre todas as possibilidades. Com outras pessoas fica muito mais fácil, ficou muito mais fácil. o fato de a gente discutir bastante em sala de aula o que ia fazer ajudava bastante. (Fonte: Entrevista)

\section{Licenciando Pedro}

A temática do Pedro envolvia conceitos de eletroquímica e foram desenvolvidos em três aulas (Quadro 25), destinadas a alunos do segundo ano do Ensino Médio. Pedro inicialmente havia programado duas aulas, porém diante da ausência de conhecimento dos alunos sobre eletronegatividade foi necessário estender a regência em mais uma aula.

\section{QUADRO 25: ATIVIDADES DESENVOLVIDAS POR PEDRO PARA CRIAR UM AMBIENTE ARGUMENTATIVO DURANTE AS AULAS DE QUÍMICA DO ENSINO MÉDIO.}

\begin{tabular}{|c|c|}
\hline Aula & Atividades desenvolvidas \\
\hline $\begin{array}{c}1^{\circ} \text { e } 2^{\circ} \text { aula } \\
\text { (100 minutos) }\end{array}$ & $\begin{array}{l}\text { Aula expositiva dialogada iniciada com } \\
\text { perguntas de revisão sobre os } \\
\text { conhecimentos prévios dos alunos sobre } \\
\text { a temática e posterior explicação dos } \\
\text { conceitos. }\end{array}$ \\
\hline $\begin{array}{c}3^{\text {o }} \text { aula } \\
\text { (50 minutos) }\end{array}$ & $\begin{array}{l}\text { Leitura de textos, por parte dos alunos, } \\
\text { com posterior questionamento por parte } \\
\text { do licenciando aos alunos sobre } \\
\text { perguntas referente às temáticas. }\end{array}$ \\
\hline
\end{tabular}

Nas duas primeiras aulas Pedro usou como metodologia a aula expositiva e na terceira desenvolveu a atividade de caráter argumentativo. Na referida atividade a argumentação foi trabalhada por meio de uma oficina de leitura com textos (quatro no total) que versavam sobre pilha, corrosão e galvanização. A metodologia seguia a leitura de trechos dos textos pelos alunos com posterior questionamento do licenciando com o intuito de promover um ambiente argumentativo. 
daquela coleção do Tito Canto ${ }^{10}$, e nesses textos pequenos né, era tratado um fenômeno de eletroquímica, só que não explicava certinho porque que acontecia. Então através da leitura eu pedia para que os alunos tentassem explicar, argumentar porque que acontecia aquilo. (Fonte: Entrevista)

Segundo Pedro a escolha da estratégia argumentativa foi baseada na carência que os alunos possuem de desenvolverem atividades que envolvam a leitura e no fato da atividade apresentar-se relativamente fácil de ser realizada, pois considerou que por ser uma atividade que envolvia a leitura poderia abranger habilidades e conteúdos das áreas de Química e Português.

(considerações de Pedro sobre os critérios utilizados na escolha da atividade argumentativa) Eu achei um pouco mais... mais fácil e mais viável... uma grande coisa que eu vejo assim pela internet, nas mídias né, porque os alunos não sabem escrever, não sabem ler, então eu forçando eles a lerem né ... ajuda, é uma coisa meio interdisciplinar português, com química. (Fonte: Entrevista)

(explicação de Pedro em relação ao procedimento da atividade) todo mundo tinha que prestar atenção da leitura da colega... eu pedi para eles falarem para mim qual era a reação do fenômeno que estava escrito no texto ... ai com os argumentos que eles iam dando eu fui tentando construir o conhecimento até chegar nesta outra questão que era uma pilha. Para construir a explicação os alunos tinham que ler o texto procurar argumentos eu falei que eles podiam consultar o caderno. O objetivo era para eles explicarem para mim o fenômeno descrito no texto. (Fonte: Vídeo- Aula Prática do Ensino de Química)

O licenciando menciona que não encontrou grandes dificuldades na elaboração da regência com foco na argumentação e sim nas condições da aula, já que a terceira aula ocorreu duas semanas após a segunda e no mesmo dia não havia energia elétrica na sala de aula. Concepção que reitera ao ser questionado pelo licenciando Tales que uma mudança na atividade pudesse gerar uma melhor argumentação.

(análise de Pedro sobre de sua regência) Eu acho que a intensão da atividade foi boa, os textos também, mas foi o que eu falei neste clima (se referindo a falta de energia elétrica na sala de aula e da atividade ser realizada duas semanas após a última aula) exatamente neste episódio não teve o feedback que eu esperava, se aplicasse de novo ... se pudesse cumprir o plano mais a risca eu acho que teria um resultado um desempenho melhor. Mas foi assim baseado em uma oficina de leitura e a partir dai era para eles argumentarem. (Fonte: VídeoAula Prática do Ensino de Química)

${ }^{10}$ O licenciando refere-se ao livro Peruzzo, F. M. e Canto, E. L.; Química na abordagem do Cotidiano; $3^{\mathrm{a}}$ edição. São Paulo: Moderna, 2003. 


\section{(discussão ocorrida em aula da disciplina de PEQ)}

Tales: E se você tivesse feito um estudo dirigido no caso, faz um estudo dirigido depois o trabalho de argumentação dos alunos, porque ele (se referindo ao aluno da aula de Química) pega o texto e ele lê, depois ai ele pergunta o que eu vou fazer com isso? Ele ainda não sabe o que vai ser feito, foi à mesma coisa que aconteceu comigo, os alunos não sabem o que vai ser feito, é um texto gigante mesmo que for menor ele não sabe o que vai ser feito com aquilo, se você dá umas questões mesmo que seja com respostas quase mecânica, mas que depois vai ajudá-lo depois na hora da discussão ia ajudar um pouco mais.

Pedro: Não sei não, sabe por quê? O problema não era tanto assim a atividade, era o dia, duas semanas depois (Pedro ministrou a segunda aula duas semanas depois da primeira) ... porque não era difícil era ler o texto e eu perguntei o que está acontecendo? Qual o fenômeno químico?

(Fonte: Vídeo- Aula Prática do Ensino de Química)

Para Pedro a dificuldade encontrada ao elaborar a regência está vinculada a não ter encontrado textos com as características que desejava o que implicou em modificá-los. Em relação a sua aprendizagem neste processo de elaboração de uma atividade argumentativa o licenciando apresenta que aprendeu a estruturar atividades desta natureza e trabalhar com textos num contexto mais provocativo. Isto se revela como um SAD Relativo às Estratégias, em que podemos identificar a justificativa de maneira implícita na transcrição abaixo (grifos nossos).

(em relação à aprendizagem do licenciando quanto à elaboração da regência) Ah, eu aprendi, estruturar uma atividade, montar uma atividade, planejar uma atividade diferente né, baseada na argumentação, estruturar ela né, no caso eu estruturei ela com os textos né mais assim provocativos para os alunos e, foi isso que eu aprendi. (Fonte: Entrevista)

Em relação à promoção da argumentação dos alunos, Pedro destaca que a princípio tentou analisar os argumentos com base no modelo de Toulmin, no entanto, percebeu que algumas se resumiam aos elementos conclusão e conhecimento básico, perpassando em muitos momentos a tentativa de adivinhação dos alunos. Para Pedro, os alunos a partir do terceiro texto deixaram de argumentar e iniciaram um processo de adivinhar o fenômeno eletroquímico. Também nas transcrições abaixo identificamos explicitações de Pedro do SAD Relativo às Estratégias

(reflexão de Pedro sobre a atividade argumentativa) A princípio eu tentei analisar o argumento deles baseado em Toulmin, mas eu desencanei, porque a apresentação deles estava muito zuada. Ai eu falei assim né no relatório de que era tipo de uma atividade investigativa, que não importava se a resposta estava 
certa ou errada, (Por quê?) o que importa é eles participarem, tem que ser otimista porque a argumentação deles não tinha uma justificativa, porque via que era mais adivinhação... ai você pergunta: você diz isso baseado em que? Eles ficam mudo... eu também travei, porque eu não sabia mais o que falar para cativar eles. (Fonte: Entrevista)

[...] Mas eu vi que alguns eram argumentos que pareciam mais adivinhação, então eles estavam tentando meio que adivinhar, como se fosse ganhar um doce ou um meio ponto na média, sei lá. Aí depois a princípio começou a vim alguns argumentos fundamentados em teoria né, tipo "ai, vai dar um choquinho”, "vai ter, vai ocorrer uma oxi-redução”, eles falavam algumas coisas desse tipo, e ai eu conseguia trabalhar um pouco dentro desses argumentos até caminhar pra ver o fenômeno certo, o fenômeno que está sendo trabalhado no texto né, descrito no texto. (Fonte: Entrevista)

Pedro reflete também que o fato dos alunos não terem muito conhecimento sobre conceitos de Química e por serem tímidos em participarem de atividades escolares que os fazem expor seu ponto de vista, seu conhecimento, ocasiona que participem em menor grau das atividades.

(considerações do licenciando sobre a dificuldade dos alunos argumentarem) Dois fatores eu acho né, o primeiro é porque às vezes eles não sabem muito química ... então ele não tem onde fundamentar a argumentação dele. Às vezes ele até fala alguma coisa, mas com vocabulário que não é da área da química, um vocabulário mais de rua, mais informal. E outro é, seria timidez mesmo né, por ele não estar acostumado com esse tipo de atividade em sala né, é uma coisa que quebra um pouco o ensino tradicional, usar os dispositivos pra se dialogar né. (Fonte: Entrevista)

Quanto à receptividade dos alunos ante a atividade argumentativa, Pedro destaca novamente as condições em que a aula foi realizada, e fala que com exceção dos alunos que dormiram os demais participaram da atividade.

(análise da participação dos alunos nas atividades) Nas duas primeiras aulas acho que eles participaram bem, agora como para a terceira aula teve, mais de, acho que teve duas semanas assim de intervalo né, porque teve feriado tal, como era a primeira aula da manhã, de segunda feira, clima de chuva né, então, teve parte da sala que dormiu, que não participou bem assim então deu, justo na atividade argumentativa eles não, a sala, não estava a sala inteira presente então ficou uma coisa meio desfalcada assim, iria ter sido melhor. (quanto à receptividade dos alunos ante a atividade argumentativa) Acho que foi positiva, eles não, não resistiram nada, não bagunçaram. (Fonte: Entrevista)

Na visão de Pedro a principal função da atividade argumentativa foi criar uma base que pudesse possibilitar aos alunos incorporar o hábito da leitura em sua rotina 
de uma maneira crítica. No entanto, apresenta que como seu foco estava em promover uma mudança atitudinal dos alunos não conseguiu "medir" a eficácia.

\begin{abstract}
(posicionamento do licenciando quanto ao papel que a atividade argumentativa deveria desempenhar na formação dos alunos) Bom a principal função era forçar os alunos a participarem, é que a argumentação nesse ambiente criado pela leitura já cativasse os alunos a participar da aula e espero né, por meio dessa atividade né que eles passem a ler os textos né, em notícias né, tenham uma postura mais crítica. (Fonte: Entrevista)
\end{abstract}

Em uma perspectiva do que um professor deve saber para conduzir atividades com caráter argumentativo, Pedro destaca a importância do docente conhecer o modelo de Toulmin, e com o tempo (prática) conseguir envolver os alunos a participarem das atividades.

(necessidade de um professor para conduzir uma atividade argumentativa) o
professor tem que conhecer a argumentação né, como funciona, o que é, talvez
conhecer o Toulmin né, a participação dele, orientou bem para avaliar a
qualidade da participação dos alunos, e eu acho que é mais pela prática né, que
aprende, então, se eu começar a usar ele vai ficando bom. (Fonte: Entrevista)

Em uma análise pensando se usaria novamente atividades argumentativas Pedro se diz totalmente favorável ao uso e acredita que a argumentação esteja vinculada às atividades do tipo investigativa. O licenciando acrescenta que se refizesse sua regência a modificaria no aspecto de ter dos estudantes a certeza de que teriam o material de apoio à aula como tabela periódica, livros etc. Podemos identificar na transcrição abaixo um SAD Relativo às Estratégias em que o licenciando apresenta os motivos de se escolher uma atividade de caráter investigativo na promoção de um ambiente argumentativo, em que apresenta a necessidade de escolher uma atividade de caráter investigativo para promover a argumentação em sala de aula.

(considerações de Pedro sobre o que modificaria ao usar atividades argumentativas como docente) a argumentação ela existe dentro dos métodos de investigação, tipo mão na massa ... (Por quêe?) então aí eu poderia trabalhar mais o lado da argumentação dentro de uma metodologia de ensino por investigação então eu poderia fazer uma atividade investigativa e olhando essa parte de argumentação também, que antes eu não olhava, nem sabia que tinha. (Fonte: Entrevista)

(considerações de Pedro sobre o que modificaria ao usar a mesma atividade argumentativa em uma ação futura) alguns materiais de apoio que eu percebi que eles não tinham, eles até tinham livros né, mas é que tinham um lá dos 
potenciais padrões, mais eles não estavam com o livro na mão, não tinha no caderno do Estado, então eu achei que isso foi um desfalque né, eu fui pra regência considerando que eles já tinham isso né, iria ter isso em mãos, tabela periódica, tal. Mas eu percebi, cheguei lá eles não tinham então, ficou uma coisa vaga acho, essa parte, então é o que eu levaria, acrescentaria, mais essa parte. Talvez o experimento de pilha, tradicional. (Fonte: Entrevista)

Para Pedro as atividades realizadas em sala de aula na disciplina de Prática do Ensino de Química foram fundamentais para que fosse possível realizar a atividade de natureza argumentativa, pois possibilitaram que tivessem uma segurança em relação a como proceder.

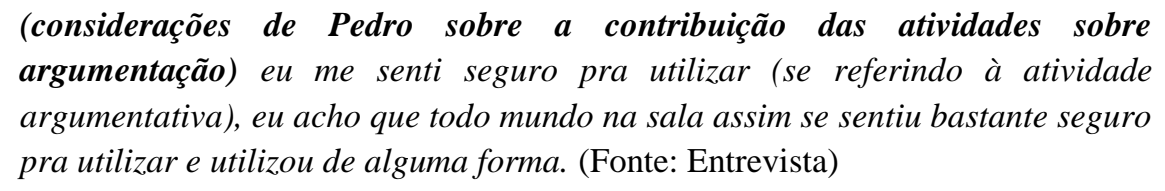

\section{Licencianda Rose}

A temática de Rose era a mesma de João e Marta estando relacionada aos impactos da extração de ferro e cobre para a sociedade, e suas aulas destinaram-se a alunos do primeiro ano do Ensino Médio. Rose no seu projeto de regência estava considerando que o assunto a ser abordado apresentava um caráter mais informativo do que conceitual. No entanto, ao preparar sua regência relacionou a extração mineral com seus aspectos químicos.

Como estratégia destinada a promover a argumentação dos alunos Rose, optou pela confecção em grupo de mapas conceituais. Sua justificativa é que ao desenvolverem o mapa os alunos teriam que argumentar em relação aos conceitos que iriam apresentar em cada nível hierárquico do mapa. Tal discussão, no ponto de vista da licencianda suscitaria a argumentação. Vemos uma reflexão da licencianda (transcrições abaixo, grifos nossos) quanto à escolha da estratégia em que apresenta o motivo pelo qual optou por mapa. Rose considera o fato de que os alunos ao terem que discutir entre si para optarem pelo posicionamento dos conceitos nos níveis hierárquicos suscitariam a argumentação. Rose expressa nesse posicionamento um SAD Relativo às Estratégias, pois expressa, as características das atividades que possibilitariam o ambiente argumentativo. 
(análise de Rose sobre o motivo de usar o mapa conceitual na promoção da argumentação) Porque eu pensei por ser uma atividade, um trabalho em grupo, e tendo em vista também que as opiniões das pessoas são diferentes mesmo que como eu disse o tema é um pouco polêmico não é aquela verdade. Nãa pode aceitar como uma verdade absoluta. Então eu pensei que eles poderiam estar trabalhando isso, essa argumentacão, no grupo, para poder montar toda a hierarquía dos conceitos no mapa e ai então seria essa troca de informação que eles estariam fazendo, né. De qual seria a melhor opcão para hierarquizar os conceitos. (Fonte: Entrevista)

A estratégia para promover a argumentação seria então na interação dos alunos da construção do mapa com posterior apresentação. E acredito que eles vão ter esta interação na hora de montar o mapa, então para discutir, ah onde que vai esse conceito como fazer a ligacão do conceito que frase a gente usa de ligação E também na hora de apresentar eles vão tá expondo a opiniãa deles. para os outros alunos ... (Fonte: Entrevista)

A atividade programada para que ocorresse a argumentação em sala de aula foi a construção do mapa conceitual em grupos. Essa construção, em grupos, possibilitou o desenvolvimento da argumentação entre os integrantes do grupo para a montagem dos conceitos e frases de ligação que melhor definem a hierarquização dos conceitos que aprenderam do assunto. Com esse tipo de atividade é possível obter evidências da aprendizagem significativa, além de desenvolver a escrita e a interpretação de texto. (Fonte: Relatório de Regência)

No entanto, para chegar até o momento de construção do mapa, a licencianda desenvolveu uma série de atividades, listada no Quadro 26, que no seu entender dariam a base para que os alunos pudessem construir o mapa. Tais atividades envolviam desde sua ação como docente em que desenvolveria uma aula, cujos conceitos seriam abordados de uma forma interativa, até as atividades dos alunos, em que ao longo das aulas teriam um papel ativo no processo de ensino-aprendizagem. A avaliação seria por Rose realizada com base nos mapas conceituais e na interação dos alunos durante a aula. 


\section{QUADRO 26: ATIVIDADES DESENVOLVIDAS POR ROSE PARA CRIAR UM AMBIENTE ARGUMENTATIVO DURANTE AS AULAS DE QUÍMICA DO ENSINO MÉDIO.}

\begin{tabular}{|c|c|c|}
\hline Aula & Atividade da licencianda & Atividade do aluno \\
\hline $\begin{array}{c}1^{\circ} \text { aula } \\
\text { (50 minutos) }\end{array}$ & $\begin{array}{l}\text { Apresentação e explicação } \\
\text { dos conceitos de forma } \\
\text { interativa. }\end{array}$ & $\begin{array}{l}\text { Escrever em cartões os } \\
\text { conceitos que durante as aulas } \\
\text { pareciam mais interesantes. } \\
\text { Ler uma reportagem, interpretar } \\
\text { o texto sobre extração mineral e } \\
\text { construir uma tabela com } \\
\text { aspectos positivos e negativos } \\
\text { da extração. }\end{array}$ \\
\hline $\begin{array}{c}2^{\circ} \text { aula } \\
\text { (50 minutos) }\end{array}$ & $\begin{array}{l}\text { Apresentação e explicação } \\
\text { dos conceitos de forma } \\
\text { interativa. Apresentação de } \\
\text { vídeos sobre a temática aos } \\
\text { estudantes. }\end{array}$ & \multirow{2}{*}{$\begin{array}{l}\text { Escrever em cartões os } \\
\text { conceitos que durante a aula } \\
\text { fossem mais interesantes e } \\
\text { participar da aula com dúvidas e } \\
\text { informações. }\end{array}$} \\
\hline $\begin{array}{c}3^{\circ} \text { aula } \\
\text { (50 minutos) }\end{array}$ & $\begin{array}{l}\text { Apresentação e explicação } \\
\text { dos conceitos de forma } \\
\text { interativa, e o uso de } \\
\text { mapas conceituais. }\end{array}$ & \\
\hline $\begin{array}{c}4^{\circ} \text { aula } \\
\text { (50 minutos) }\end{array}$ & $\begin{array}{l}\text { Ajudar os grupos de alunos } \\
\text { na construção dos mapas } \\
\text { conceituais. }\end{array}$ & $\begin{array}{l}\text { Construir os mapas conceituais } \\
\text { em grupos e apresentá-los aos } \\
\text { demais alunos da sala. }\end{array}$ \\
\hline
\end{tabular}

Um dos aspectos também de apreensão inicial de Rose, logo na apresentação do seu projeto de regência, era que seu primeiro dia de aula precedia a um feriado, o que poderia culminar na ausência de grande parte dos alunos. Durante a própria apresentação os envolvidos na disciplina deram sugestões do que poderia ser realizado caso isto acontecesse.

(discussão dos licenciandos durante atividade de apresentação do projeto de regência ocorrida na disciplina)

Tales: Então você tem que estar preparada para que um dia apareça dez e no outro vinte alunos e você tem que continuar com a matéria.

Rose: Ah sim, mas eu só falo em relação a cumprir o plano de aula.

Professora: o que você pode pensa é em um plano B. Se vier pouco aluno no primeiro dia, no segundo você precisa ter um texto falando que na aula passada foi discutido tal assunto, e com base neste texto...

Rose: Ou também fazer com que os alunos que estavam presentes (se referindo à presença na aula véspera do feriado) sejam colocados em grupos de alunos que faltaram. 
João: $\operatorname{Sim}$

Rose: tentar dividir a sala para que também depois eles possam passar um para os outros que não vieram.

Professora: É mais por via das dúvidas faz algum texto de base para que eles possam se orientar.

(Fonte: Vídeo- Aula Prática do Ensino de Química)

Para Rose, uma parcela dos alunos argumentou em suas aulas, já que pôde perceber ao percorrer os grupos, no momento em que confeccionavam os mapas, que os alunos estavam discutindo. Além disso, aponta que a argumentação ocorreu também durante os momentos de aula expositiva, pois os alunos participavam com questões as quais geravam discussões. Rose faz uma reflexão sobre como os posicionamentos dos alunos foram se alterando ao longo da ação didática de participação de atividades argumentativas, representando um SAD Relativo às Estratégias, já que deixa claro a importância de cada ação com a respectiva implicação no processo de ensino-aprendizagem.

(considerações de Rose sobre a argumentação dos alunos em sala de aula) Pela posição deles por algumas questões que foram levantadas durante a aula e pela construção do mapa que eu vi como começou e o jeito que foi finalizado também. Como ficou no final, teve as mudanças e eu acredito também que teve essa comunicação entre os grupos. (Fonte: Entrevista)

Porque como eu disse foram as informacões que eu trazia eu vi que os alunos eles ficavam assim em dúvida certas vezes, né? E eles expunham a posição deles, a opiniãa deles perguntando: mas o porquê disso? Se é assim assado? Por que que está falando que é assim? Então você já vê que você começa a ter uma posição sobre o assunto e fazer comparações também porque com os conhecimentos prévios deles... então eu achei que por isso eles tiveram essa vontade de fazer a argumentação de ter a argumentação. (Fonte: Entrevista)

Rose relata que teve que lidar com um fato inesperado ao pedir aos alunos que elaborassem o mapa conceitual, como na terceira aula ela explicou sobre o mapa e informou que eles iriam construir um na aula seguinte uma aluna o trouxe pronto. A aluna alegou que não gostava de trabalhar em grupo com os colegas de sua sala. Após algumas tentativas de tentar convencer a aluna a fazer o mapa em grupo e de refletir sobre a situação achou prudente deixá-la realizar a atividade individualmente.

(relato de Rose sobre imprevisto ocorrido em sua regência) Teve uma menina que trouxe pronto (se referindo ao mapa) e chegou na hora ela disse que queria fazer sozinha. Ela falou: "Ai dona, deixa eu fazer sozinha porque eu não gosto 
de ninguém dessa sala"... Eu falei para ela que essa atividade eu queria que fizesse em grupo, né? Porque a intenção é que vocês se comuniquem com o grupo para fazer a montagem. Mas você tem esse problema. Eu não posso forçar a menina a ficar lá. Eu acho que forçando acaba até atrapalhando do que melhorando. E ai ela falou: "Então dona eu já trouxe até pronto". (Fonte: Vídeo- Aula Prática do Ensino de Química)

No entanto, para Rose, essa situação não impossibilitou de ter sido criado um ambiente argumentativo, já que a mesma criou com a aluna um ambiente questionador em que esta precisava justificar as proposições dos mapas, pois muitas delas se encontravam erradas. Podemos considerar que nesse momento a licencianda explicita ações que estão diretamente relacionadas ao SAD de Gerenciar Ideias Instigando Questionamentos e ao SAD Gerenciar Ideias promovendo Justificação, como podemos observar nas transcrições abaixo (grifos nossos), pois, fica claro na fala de Rose sua consciência da importância do seu papel como mediadora na promoção de questionamentos e na justificação de ideias da aluna.

(análise de Rose sobre o processo de elaboração do mapa feito individualmente por uma aluna) Tinha algumas coisas que não estavam em concordância, inclusive assim dos conceitos, alguma coisa ela não entendeu muito bem. Ai eu fui ajudando ela e a gente montou um novo mapa. Quer dizer, fui conduzindo ela porque foi ela quem montou. E ai ficou um resultado muito bom. Eu acho que o dela foi o mais trabalhado. Eu acho que ela sozinha fez muito bem ... como e. disse ela tinha feito o mapa errado então eu falava assim: "Mas o que você quis dizer com isso?". E ai ela falava: "Não é para falar isso isso, isso.". Ai eu falava: "Pensa bem. O que você acha se? Esse conceito aqui está errado nãa é isso que significa. E se a gente pensasse de outra maneira? De outra forma?". Ou seja, eu questionava ela e tentava conduzir ela para a resposta certa também. (Fonte: Vídeo- Aula Prática do Ensino de Química)

A licencianda também destaca a importância de sua ação como docente ao instigar a participação de alunos que se apresentavam inerte às discussões. Rose apresenta que ao percorrer os grupos pôde ver que os alunos estavam discutindo entre si, de maneira a possibilitar um ambiente argumentativo.

(análise de Rose sobre a participação dos alunos nas discussões para a construção do mapa e de sua ação na suscitação de questionamentos) Porque eu vi na hora que eu estava passando pelos grupos, eu via que eles estavam discutindo. Alguns levaram bem a sério e outros não. Mas, eu vi que eles ficavam perguntando pro outro, questionando: "Essa aqui é melhor, Por quê?" "Porque eu acho que assim fica melhor". Às vezes eu dava, assim, umas cutucadas para eles tentarem desenvolver, aqueles que eram um pouco mais preguiçosos. (Fonte: Vídeo- Aula Prática do Ensino de Química) 
Para Rose, a atividade argumentativa assume um papel em que possibilita a troca de informações entre o professor e os alunos, tirando o foco de aulas nas quais a informação segue somente um sentido professor-aluno. Desta maneira, para Rose um professor que deseja desenvolver atividade desta natureza precisa ter claro os objetivos que deseja alcançar no processo de ensino e aprendizagem e a partir deles optar por estratégias que possibilitem alcançá-los. Além disso, a atividade argumentativa permite que alunos melhorem sua habilidade de expressão oral e ampliem seu vocabulário, que de acordo com Rose é limitado. Este sentido de troca de informações entre os envolvidos no processo de ensino, das necessidades de um professor para desenvolver atividades de caráter argumentativo as contribuições destas são explicitadas por Rose nos trechos abaixo.

(considerações de Rose sobre a função da atividade argumentativa) Eu acho que é a troca. É a troca de informações é o principal. É aquela coisa de você querer dar e querer receber também. Não ficar só em uma posição. Só querendo dar ou só querendo receber. É importante a troca. (Fonte: Entrevista)

(considerações de Rose sobre os conhecimentos necessários a um professor para desenvolver atividades argumentativas) Primeiro eu acho que ele deve estabelecer os objetivos dele. Então, quais são os objetivos que ele quer alcançar com os alunos com essa atividade. E então depois correr atrás da melhor forma da atividade que melhor se adapta ao conteúdo que ele quer explorar com a argumentação. (Fonte: Entrevista)

(posicionamento da licencianda sobre as contribuições das atividades argumentativas) Eu acho que muito vocabulário deles, provavelmente como a gente também viu no vídeo, né? Que eles falam, muitas vezes eles gesticulam porque eles ainda não tem uma formação, eles não acham verbos, eles não acham palavras pra tentar transmitir aquilo que eles estão pensando. Eu acho que isso é uma forma muito boa de desenvolver isso, desenvolver a fala, a comunicação deles. Não só tentar gesticular e ficar com aquele vocabulário restrito. Amplia um pouco. (Fonte: Entrevista)

Rose apresenta que não teve dificuldade em relação à implementação da estratégia argumentativa, mas que sua apreensão estava relacionada a escolher uma atividade que agradasse os alunos, objetivo que alcançou ao optar pelo desenvolvimento do mapa conceitual. Em sua trajetória de aprendizagem, ao ter que desenvolver uma atividade de natureza argumentativa, a licencianda destaca que o momento da regência se constituiu em uma experiência ímpar para que pudesse experimentar situações docentes as quais em sua concepção inicial demandariam muito tempo e não obteria os resultados esperado. 
(reflexão de Rose sobre sua regência) Eu gostei, assim, dela, sabe? Eu até achei que foi melhor do que a minha de Ciências. E o assunto da de Ciências eu manjava mais que foi até um assunto que eu trabalhei, mas eu acho que foi pelo retorno dos alunos, assim, não teve aquela bagunça, sabe? Eu acho que eles entenderam bem o conteúdo, sabe? Não o conteúdo, mas o meu objetivo com eles. Eu acho que eu consegui atingir o objetivo. Eu concordo que muitas vezes eu falhei ... principalmente aquela parte da tabela periódica (a licencianda não soube responder uma pergunta do aluno sobre uma família da tabela periódica) mas eu acho que todo mundo vai erra nela, não tem jeito, não da pra lembrar de tudo. Como eu disse, eu preferi não falar do que falar errado. E...mas acho que de uma maneira geral eu fiquei bem satisfeita com o resultado. (Fonte: Entrevista)

A licencianda aponta que se não fosse pela vivencia com a regência nunca iria desenvolver uma aula de natureza argumentativa em sua atuação docente e que aprendeu a vencer barreiras quanto a profissão docente. Rose Faz uma reflexão de como a oportunidade de desenvolver a regência numa perspectiva argumentativa trouxe crescimento ao seu aprendizado como docente, conforme transcrito abaixo.

(considerações de Rose sobre o que aprendeu ao elaborar a regência) Eu acho que foi vencer uma barreira de uma atividade. Porque é aquela coisa, uma atividade diferenciada é tempo gasto que a gente tem pra pesquisar e ir atrás. Muitas vezes a gente tem um pouco de receio da resposta dos alunos da atitude. E se isso vai ser bom ou não. A gente sempre fica com aquela dúvida. Então sãa várias dúvidas e essa questão do tempo que leva e a gente fala será que vai ser bom mesmo. Então você acaba indo para o tradicional mesmo. ou não quer fazer nada diferente. Então eu acho que valeu a pena porque eu acho que a intencão é essa mesmo da regência. A gente tentar fazer alguma coisa diferente. Porque essa parte de argumentacão pelo menos eu ainda não tinha visto no curso eu vi agora na parte final do curso na aula de química e a gente vê que é possível ter esse tipo de argumentação na área de ciências exatas porque muitas vezes a gente acha que é mais fácil na parte de humanas. (Fonte: Entrevista)

No que concerne à participação dos alunos durante as aulas Rose aponta que poucos participaram, mas os que se envolveram, foram efetivos em sua participação. Percebemos a colocação de Rose sobre a importância em se trabalhar com atividade que possam culminar em um posicionamento crítico dos alunos, como evidenciado na transcrição abaixo.

(considerações de Rose sobre a participação dos alunos nas atividades desenvolvidas em sua regência) Eu acho que poucos participaram. Mas eu acho que os poucos que participaram eles foram bem ativos, né? Tanto nas falas quanto nas atividades escritas... Eu achei que quando eu expliquei para eles na primeira aula, na verdade, na segunda eu achei que eles ficaram bem interessados (se referindo à atividade do mapa), o que eu gostei foi que um dos alunos se interessou bastante e até pediu para eu mandar o exemplo pra ele por 
e-mail porque ele queria estudar melhor como fazer. Eu cheguei a mandar, eu peguei o e-mail dele, e mandei, ele até me agradeceu, respondeu agradecendo. (Fonte: Entrevista)

Para Rose, inicialmente, a atividade argumentativa estaria atrelada ao desenvolvimento do mapa conceitual, porém percebeu que elementos da argumentação permearam todas as atividades desenvolvidas durante a regência.

(considerações de Rose em relação à estratégia desenvolvida para promover a argumentação) Então, assim, o que eu tinha pensado era no mapa conceitual, mas durante a regência eu vi que o tema é bem, tem uma parte um pouco polêmica né, da questão ambiental, da questão social e econômica que tá envolvido por trás do tema. E eu achei que durante a minha apresentação ouve também posições dos alunos, eles também argumentaram..., os pontos de vista deles. Então, eu achei que como um todo assim a minha regência teve um pouco de argumentação durante todo. (Fonte: Entrevista)

$\mathrm{O}$ fato de desenvolver uma atividade numa perspectiva de promover a argumentação dos alunos, inicialmente causou na licencianda certo receio de que não conseguiria promovê-la. Dentre os motivos destaca a necessidade de o professor estar preparado, saber o conteúdo a ser ensinado, pois se o aluno o questiona, precisa responder e por demandar mais trabalho na sua elaboração.

\begin{abstract}
(impressão de Rose ao ter que fazer uma atividade de natureza argumentativa) Bom, é aquilo que eu já falei, dá um pouco de trabalho, porque você tem que ter um domínio daquilo então se o aluno te pergunta você tem que estar preparada pra responder e ter uma posição sobre aquilo. E acho que é isso... Mas eu achei sinceramente que fosse ser uma coisa mais difícil sabe? Mas na hora, assim, não foi. E eu acho também que pegando prática desenvolvendo outras atividades ou até criando novas eu acho que vale a pena, não precisa ficar com medo. (Fonte: Entrevista)
\end{abstract}

No decorrer do desenvolvimento e aplicação da regência a licencianda foi alterando significativamente sua concepção em relação ao envolvimento dos alunos nas atividades. Inicialmente como mostra na transcrição abaixo, ao apresentar a primeira versão do seu projeto de regência, mostra-se totalmente incrédula da participação dos alunos nas atividades propostas.

(transcrição da discussão na apresentação da primeira versão do projeto de regência)

Rose: Eu estarei com o roteiro do Powerpoint, mas estarei interagindo (se referindo a metodologia da primeira aula).

Professora: mas se eles não interagirem você vai ficar com um monte de slides. 
Rose: Mas sinceramente eu não consigo pensar em nada diferente eu pensei em algumas informações eu não apresento no impresso, então eles teriam que olhar o slide e completar o que está na folha sabe.

Professora: mas fazer cópia?

Rose: É para fazer cópia ou observações. Se bem que eu conheço, eles não vão fazer nada.

(Fonte: Vídeo- Aula Prática do Ensino de Química)

No decorrer da discussão da apresentação do projeto, diferentes ideias foram suscitadas pelos licenciandos, pela docente e pela própria pesquisadora, para construir juntamente com Rose, uma aula em que fosse mais efetiva a participação dos alunos. Uma das sugestões realizadas e incorporada pela licencianda foi que durante as aulas os alunos iriam escrevendo em cartões os conceitos os quais considerassem importantes sobre a temática apresentada.

(discussão ocorrida na apresentação do projeto de regência na disciplina de $P E Q)$

Professora: outra coisa que você pode fazer talvez seja na primeira aula ainda, dá imagens e uns pedaços de cartolinas para eles escreverem os conceitos que eles acham que são importantes durante a discussão. Ai você recolhe no final da aula e organiza porque vão se repetir, entrega dizendo que são os conceitos que eles considerarem como importantes.

Rose: Mas ai eu entrego para a mesma pessoa?

Professora: Não, por exemplo, eu tenho dez duplas ai você veria quais são os conceitos que as duplas colocaram, que vai aparecer conceitos repetidos, e você faria uma seleção de todos os conceitos e disponibilizaria em algum lugar...

Rose: Ah tá, seriam conceitos iguais para todos.

Professora: Isso, igual para todos. (Fonte: Vídeo- Aula Prática do Ensino de Química)

(discussão na disciplina de PEQ após a regência de Rose)

Rose: O que eu achei legal é que muitos não participaram da aula, mas quando chegou no mapa, eles foram, eles fizeram, eles não se recusaram a fazer. Claro teve alguns que ficaram bem pobrezinho, que eles fizeram para não dar trabalho, mas todos fizeram e eu fiquei bem satisfeita.

(Fonte: Vídeo- Aula Prática do Ensino de Química) 
Ao apresentar sua reflexão de regência, Rose fez questão de mostrar aos colegas, à professora e à pesquisadora como havia ficado sua apresentação modificada com base nas sugestões discutidas na apresentação do projeto, conforme observado na transcrição abaixo.

\section{(discussão ocorrida na reflexão após a regência)}

Então né, eu falei sobre a mineração, peguei as ideias que a gente tinha discutido aqui no dia da apresentação do plano (se referindo à apresentação do projeto)... fiz as perguntas das figuras, então eu comecei colocando algumas figuras... Então fiz as perguntas para eles analisarem (se referindo aos alunos darem sua impressão sobre as figuras relacionadas a mineração), mas a princípio era para eles ficarem em dupla, mas acabaram ficando individual mesmo, mas eles falaram, eu mostrei do que falava as figuras.

João: Vocêfez as perguntas das imagens mesmo $?^{11}$

Rose: é

João Ah que legal... E eles responderam?

Rose: Então alguns falaram assim Ah é aterro sanitário, eu queria até que chegassem nisso, mas falaram mineração. Eu comecei com isso para introduzir o assunto. Eu cheguei mostrando essa imagem e fomos discutindo.

Comecei a aula e mostrei para eles também uma reportagem que a gente sugeriu aqui ...

Tales: Nossa! ficou ótimo com as sugestões.

(Fonte: Vídeo- Aula Prática do Ensino de Química)

Em relação às atividades desenvolvidas na disciplina, com o intuito de possibilitar uma base de conhecimentos sobre argumentação aos licenciandos, Rose revela que ter contato com a literatura a qual aborda as atividades argumentativas foi fundamental para a sua formação em relação a atividades desta natureza, conforme transcrição abaixo.

(em relação à formação de Rose para o desenvolvimento de atividades argumentativas) Eu acho que foi fundamental aprender como que funciona, como que aqueles textos que a gente leu sobre os vários tipos de atividades que envolvem argumentação. Então a gente teve conhecimento sobre essas diferentes atividades, e saber do conceito como funciona. (Fonte: Entrevista)

\footnotetext{
${ }^{11}$ Durante a apresentação do projeto de regência foi sugerido a Rose que no primeiro dia de aula levasse imagens de diferentes aspectos da mineração para que os alunos pudessem refletir sobre elas.
} 
Além disso, Rose também destaca a importância das atividades durante sua graduação que possibilitaram um contato direto com o mundo escolar da educação básica, desta vez em um papel de docente. Dá ainda destaque para a importância de durante sua formação ter trabalhado com material bibliográfico sobre a argumentação.

(Rose destacando um momento significativo na sua formação na graduação) Eu acho que são vários na verdade. Mas é aquilo que eu tinha comentado anteriormente. Eu acho que são essas atividades que a gente tem que ir até a escola, e conviver, e investigar. Eu acho que seria mais esse tipo de atividade. (Fonte: Entrevista)

\section{Licenciando Tales}

O tema da regência de Tales envolvia os ciclos biogeoquímicos e as aulas foram ministradas para uma turma de terceiro ano do Ensino Médio. A regência demandou quatro aulas (Quadro 27), em que na primeira e segunda foi realizada uma atividade dialogada expositiva e na terceira e quarta, na visão de Tales, foi desenvolvida uma atividade destinada à promoção da argumentação dos alunos. Na terceira aula os alunos leram um texto sobre Ciclos biogeoquímicos e na quarta aula o licenciando apresentou cinco afirmações sobre o texto em que os alunos, em grupo, deveriam justificar se eram verdadeiras ou falsas.

\section{QUADRO 27: ATIVIDADES DESENVOLVIDAS POR ROSE PARA CRIAR UM AMBIENTE ARGUMENTATIVO DURANTE AS AULAS DE QUÍMICA DO ENSINO MÉDIO.}

\begin{tabular}{c|c}
\hline \hline Aula & \multicolumn{1}{c}{ Atividades desenvolvidas } \\
\hline \hline $\begin{array}{c}1^{\circ} \text { e } 2^{\circ} \text { aula } \\
(100 \text { minutos })\end{array}$ & $\begin{array}{l}\text { Aula expositiva sobre a temática usando } \\
\text { lousa/giz e PowerPoint. }\end{array}$ \\
\hline $\begin{array}{c}3^{\circ} \text { aula } \\
(50 \text { minutos })\end{array}$ & Leitura de um texto sobre a temática. \\
\hline $\begin{array}{c}\text { o aula } \\
(50 \text { minutos })\end{array}$ & $\begin{array}{l}\text { Atividade de justificação de veracidade de } \\
\text { afirmativas relacionadas ao texto. }\end{array}$ \\
\hline
\end{tabular}


Durante a aula expositiva, o licenciando destaca que fez perguntas e comentários aos alunos na busca de promover um feedback, de maneira a despertar um maior interesse destes pelo assunto, conforme observado abaixo..

(reflexão do licenciando sobre sua aula expositiva) A aula se desenrolou normalmente ficando um pouco expositiva dialogada demais, mas foi intercalada com perguntas ou comentários dos alunos como uma forma de feedback da atenção deste para o professor e para o conteúdo que estava sendo ministrado. (Fonte: Relatório de regência)

Tales também procurou usar o modelo de Toulmin para promover o ambiente argumentativo, em que forneceu o Dado e os alunos com base no Conhecimento Básico oriundo da aula teórica e do texto de apoio deveriam construir os argumentos para concluírem suas argumentações. Neste aspecto podemos considerar um SAD de Conhecer os Elementos dos Argumentos, pois o licenciando apresenta a importância da presença dos elementos do argumento na elaboração de atividades de natureza argumentativa.

(considerações de Tales em relação ao desenvolvimento da atividade argumentativa) Notou-se que para a mínima quantidade de alunos que participaram da discussão um ensaio do que seria uma atividade argumentativa apoiada, por exemplo no modelo de Toulmin, o qual para uma argumentação o aluno recebe um dado e a partir de um conhecimento básico constrói sua argumentação. O dado (afirmacão) foi proposto o oluno por meio dos conhecimentos básicos (aula teórica e texto de apoio) montou seus argumentos. Sendo assim uma atividade argumentativa simples, que se julga aqui, um ensaio de argumentacão foi alcançado, fato ainda comprovado pela redacão de pequenas respostas que os alunos fizeram sobre as afirmacões. (Fonte: Relatório de regência)

Em relação a desenvolver atividades de natureza argumentativa, o licenciando apresenta que é possível realizá-las desde que: o professor e alunos estejam preparados; o professor tenha uma base sólida do conteúdo a ser trabalhado e que consiga ser um bom mediador despertando o interesse dos alunos. Além disso, apresenta alguns aspectos que dificultam a argumentação como a falta de motivação e a timidez dos alunos.

Observamos, nas transcrições abaixo, uma reflexão crítica e consciente do licenciando quanto ao desenvolvimento das atividades argumentativas e, principalmente, quanto ao seu papel como mediador das atividades, expressando 
assim um SAD Relativo às Estratégias, o qual serviu para a análise da ação, mas também, como base para as próximas atividades docentes desta natureza.

(reflexão de Tales quanto às necessidades para desenvolver atividades argumentativas) Vontade, tempo, motivação que você tem o professor muitas vezes ... muitas vezes não estão a fim, então se eu perguntar sobre fotossíntese pra eles, e trabalhar isso, se eles não estiverem entendendo não vão falar nada. Eu acho que a vergonha principalmente existe um problema sério na escola, que eu entendo que de pessoas são pessoas e outras são outras, então se eu tenho facilidade pra não ter vergonha de falar, tem aquele aluno que não tem, mas mesmo assim você teria que ele poderia falar, mas o que falta muito mais é educação entre os outros. (Fonte: Entrevista)

Tales, também, considera como fundamental a um professor que deseja trabalhar com atividades argumentativas saber buscar informações em fontes confiáveis e coloca como ideal que os professores da Educação Básica e universidades tivessem um elo permanente de colaboração. Identificamos na transcrição abaixo uma SAD Relativo às Estratégias, em que Tales justifica a importância de uma busca constante de atualização do professor para trabalhar a argumentação em sala de aula, buscando o uso de estratégias mais efetivas no processo de ensino.

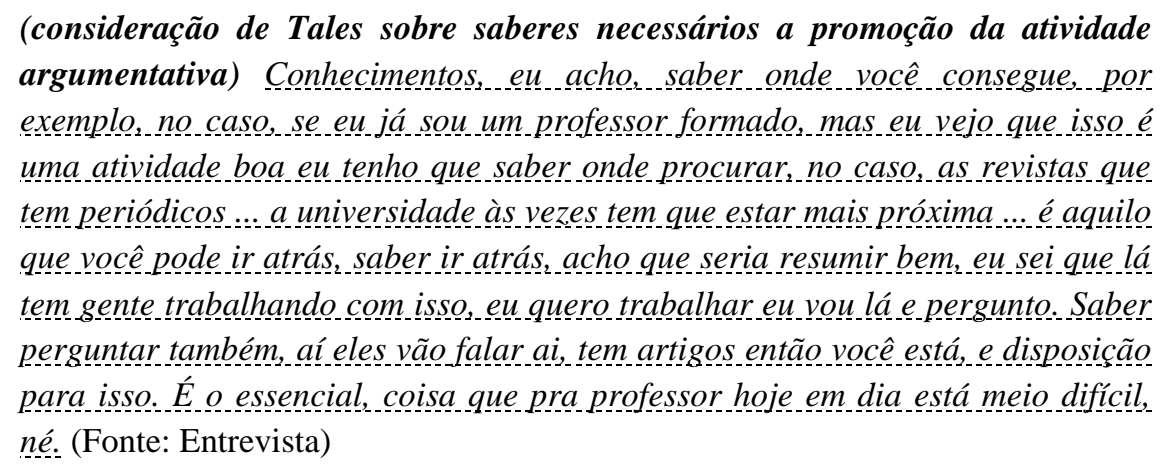

Sobre a opinião de Tales com relação a trabalhar atividades argumentativas em sala de aula, o licenciando se diz totalmente favorável já que elas podem aproximar alunos e professores. Percebeu que, quando estava ministrando a aula expositiva, ficava muito distante dos alunos, já na atividade argumentativa conseguiu se aproximar deles. Além disso, Tales tem a concepção que o papel da atividade argumentativa devia desempenhar na sua aula estava relacionado a colaborar na formação do cidadão para enfrentar a sociedade, pois a argumentação permeia todos 
os aspectos do nosso cotidiano e colabora para o desenvolvimento do conhecimento.

Tal posicionamento nos leva a uma explicitação do SAD dos Fins Educacionais.

Ao mesmo tempo em que considera importante o trabalho de atividades de natureza argumentativa. Tales apresenta que ficou totalmente inseguro para realizar suas atividades e considerando a sua personalidade acredita que isso dificultou um pouco a promoção de um ambiente argumentativo.

(reflexão do licenciando de como se sentiu a desenvolver uma atividade de natureza argumentativa) Inseguro só, e isso eu não sei esconder muitas vezes isso ainda não. E eu acho que a vergonha eu sei esconder diante dos alunos, às vezes a gente treme, a gente brinca, tenta aproximar dos alunos no caso da vergonha, mas no caso da argumentação eu não sabia, eu não estava seguro naquilo, e quando eu não fico seguro eu fico meio mal humorado. Você viu minha cara, depois que eu entrei na sala e comecei a fazer eu acho que mudou um pouco a minha cara, mas até começar e ver que aquilo estava dando certo eu me senti totalmente inseguro. (Fonte: Entrevista)

Refletindo sobre sua regência, Tales afirma que se pudesse reapresentá-la iria modificar as afirmações ${ }^{12}$, as escrevendo de uma maneira mais elaborada, já que as fez simples considerando sua insegurança. Também modificaria sua maneira de apresentar a aula expositiva, pois concluiu que sempre se mantinha na mesma posição, o que se justifica em certa medida, em função da necessidade de estar próximo ao computador para passar os slides. Tais aspectos podem ser observados nas transcrições abaixo.

(reflexão de Tales sobre o que modificaria se pudesse refazer a regência) eu acho que eu montaria afirmações um pouco mais elaboradas, por que as minhas afirmações foram um tanto quanto simples, mas isso não mostrou que os alunos não saberiam, é eu não saberia depois defendê-los no caso, acho que o jeito que foi montado foi mais a minha insegurança do que, de que eles trabalhariam muito bem. Seria uma coisa bem mais elaborada. (Fonte: Entrevista)

(reflexão de Tales sobre sua ação docente) ter ficado muito em um único lugar, porque querendo ou não o data show quando você não tem aquele equipamento que você pode mandar os slides enquanto você está bem longe da sala, eu acho que se tivesse eu teria andado um pouco mais. Então focaliza a aula eu estou sempre ali naquele lugar (se referindo à gravação em vídeo de sua regência), sempre naquela posição, e isso querendo ou não é maçante para o aluno... tem, tirando o mal humor do outro dia que eu acho que é totalmente errado você chegar e empurrar para os alunos se eles não tem culpa de nada, certo, mas

\footnotetext{
12 Tales na sua regência apresentou afirmações sobre a temática aos alunos e estes tinham que
} justificar a veracidade ou não das afirmações. 
como era uma insegurança minha, eu tiraria, ou seja uns seis e meio, sete (se referindo a uma nota que daria a sua regência). (Fonte: Entrevista)

Quanto ao seu aprendizado Tales considera que aprendeu a necessidade de estar bem preparado tanto em relação ao conteúdo como em relação à metodologia a ser utilizada, pois estes aspectos possibilitam que o aluno veja maior segurança no docente o que facilita o processo de ensino-aprendizagem.

(considerações de Tales sobre o que aprendeu ao desenvolver atividade de natureza argumentativa) tem que se preparar, se você vai trabalhar argumentação você tem que se preparar, tanto sobre o conteúdo que você vai trabalhar naquela atividade, você nunca você vai saber tudo, mas o máximo que você conseguir descobrir sobre isso é interessante pra você para trabalhar, porque você não é, você não vai ser outro que está aprendendo, a gente sempre aprende... deixar os alunos mais seguros daquilo que você está ensinando. (Fonte: Entrevista) 


\section{DISCUSSÃO}

Buscamos nesta seção interpretar os resultados com base na literatura, de maneira a destacar as similaridades e discrepâncias, ampliar nossa visão em relação aos dados e apresentar uma interpretação dos fenômenos. Iniciaremos com as concepções dos licenciandos sobre a argumentação, apresentaremos momentos principais de reflexões da trajetória sobre a prática docente dos licenciandos e finalizaremos abordando a discussão sobre o desenvolvimento e mobilização dos Saberes de Argumentação Docente. Destacamos que, embora apresentado os momentos de reflexão sobre a prática docente dos licenciandos separados da mobilização dos saberes docentes, consideramos que esses processos se fundem.

\subsection{Concepções dos licenciandos sobre argumentação}

As concepções de argumentação dos licenciandos que fizeram parte desta investigação vão ao encontro de ser uma atividade social, intelectual e verbal, que visa à aprovação de um auditório sobre um determinado assunto por meio de argumentos, os quais são usados para justificar ou refutar uma ou várias opiniões como defendem Vieira e Nascimento (2009b). Nesta perspectiva, considera-se a argumentação como um processo em que os envolvidos necessitam apresentar seus posicionamentos, contrastá-los e justificá-los mediante um público. Tais justificativas devem estar baseadas em informações, conhecimentos e bases confiáveis para defendê-los, o que lhes dará um caráter mais completo ao argumento, já que leis jurídicas e científicas podem validá-las (SÁ e QUEIROZ, 2009). 
$\mathrm{O}$ aspecto mencionado pelos licenciandos de usar a argumentação com o intuito de defender ou justificar uma posição é também referenciado em trabalhos da literatura. Islas, Sgro e Pesa (2009) expõem que para argumentar deve-se utilizar de estratégias verbais para defender uma ideia própria e/ou para replicar uma alheia, com a intenção de chegar a um acordo. Patronis, Potari e Spiliotopoulou (1999), defendem que as ideias apresentadas, ou seja, os argumentos podem ser classificados como sendo de defesa ou ataque.

Sá e Queiroz (2007) também endossam esta opinião, pois apresentam que a argumentação é uma atividade social, intelectual e verbal utilizada para justificar ou refutar uma opinião e que consiste em fazer declarações considerando o receptor e a finalidade com a qual se emitem. Gutiérrez e Correa (2008) apresentam a argumentação como um discurso destinado a resolver um conflito de opiniões por meio da avaliação da aceitabilidade dos sujeitos envolvidos. Tal avaliação depende da capacidade dos interlocutores para resolverem o determinado problema.

Em um contexto de sala de aula, os licenciandos mencionam que se pode argumentar em um papel de aluno ou professor. No primeiro âmbito, o licenciando assume a argumentação como uma maneira do aluno demonstrar o conhecimento que possui. Já no contexto do professor encontramos concepções dos licenciandos que consideram a argumentação num papel de transmissão do conhecimento, o que está em relação direta com a argumentação em uma conotação retórica a qual se caracteriza com o docente em um processo de transmissão de conhecimentos (MONTEIRO e TEIXEIRA, 2004). Neste tipo de argumentação o docente utiliza ferramentas retóricas para persuadir os alunos, num contexto em que as ideias dos mesmos não são levadas em consideração.

Resultado, em coerência com o acima descrito, foi obtido ao questionarmos os licenciandos sobre situações que haviam vivenciado como alunos ou professores nas quais a argumentação tenha ocorrido. Três, dos seis licenciandos afirmaram argumentar como alunos em um processo de comprovar a aprendizagem, ou seja, em uma conotação retórica.

Ainda em relação a momentos de argumentação como alunos, identificamos respostas em que esta foi desenvolvida em um contexto no qual tiveram que se 
posicionar a favor ou contra determinado assunto. Dando ênfase à referida estratégia ao Ensino de Ciências, destaca-se que atividades com este perfil podem contribuir para a construção de uma visão científica mais realista, uma vez que a Natureza da Ciência é marcada pelo caráter argumentativo em uma concepção extremamente controversa.

No trabalho desenvolvido por Perez, Rebechi, Azevedo, Schreiner, Mattia, Slowik e Oliveira (2011) identifica-se uma abordagem sobre o aspecto acima mencionado. Os autores promoveram um debate em sala de aula com alunos de um curso de Ciências Biológicas; no qual um grupo tinha que se posicionar a favor e o outro contra o mercado de carbono e o uso de animais em experimentos científicos.

Os referidos autores concluem o trabalho de maneira a reafirmar a importância do Ensino das Ciências a partir da abordagem de situações controversas visando o desenvolvimento de argumentos, uma vez que o raciocínio argumentativo é uma das dimensões do trabalho científico. No entanto, destacam que, em atividades como esta, deve ser indicado aos alunos textos de natureza científica, possibilitando um maior embasamento teórico aos mesmos, além da busca de informações visando à construção de argumentos mais consistentes, e também a facilitação no uso de diferentes tipos de argumentos, como retóricos, dialógicos, racionais e persuasivos. Propõem que nesse tipo de atividade

\section{[...] o estudante poderá se armar de ferramentas teóricas para convencer o outro, para examinar alternativas, para buscar solução para um problema e até para chegar a um consenso. Assim, o estudante estará vivenciando atividades de propor e discutir ideias, ou seja, estará fazendo Ciência. (PEREZ et al., 2011, p. 149)}

Outro aspecto analisado em relação aos licenciandos como sendo os sujeitos que argumentam, é que estes apresentam a necessidade de se prepararem de uma maneira formal, o que irá proporcionar sua segurança no processo de argumentação. Destacam-se destes resultados que os licenciandos parecem não considerarem que a argumentação pode ocorrer a qualquer momento no processo de ensinoaprendizagem. A análise indica que os mesmos a consideram como sendo um evento, requerendo, assim, uma profunda preparação. No entanto, ao serem questionados sobre o que pensavam sobre a promoção da argumentação em sala de aula os seis licenciandos se posicionaram como favoráveis. 
Quanto às justificativas, sobre o porquê de trabalhar a argumentação, destacase a contribuição desta no processo de ensino-aprendizagem dos conceitos científicos. Tal concepção vai ao encontro do que preconiza Sardà e Puig (2000), de que o fundamento da Ciência escolar é importante na discussão dos critérios para avaliar as teorias científicas, o que leva a uma postura do professor de proporcionar situações nas quais se possa falar na sala de aula de reflexões existentes entre as hipóteses, os fenômenos, os experimentos, os modelos teóricos e a evolução das teorias.

De acordo com Sardà e Puig (2000), esse procedimento possibilita ao aluno entrar no mundo da Ciência, na medida em que precisa utilizar os instrumentos conceituais e procedimentais que a cultura científica vai construindo, para falar, escrever e ler Ciências. Isso é, também, o que lhes proporciona subsídios para aprender a estruturar seu discurso argumentativo. As categorias obtidas das respostas dos licenciandos abarcaram os aspectos mencionados por Sardà e Puig (2000) em relação aos objetivos gerais do uso da argumentação no processo de ensinoaprendizagem, sendo: a compreensão do conhecimento científico, a formação do cidadão crítico (PATRONIS, PORTARI e SPILIOTOPOULOU, 2010) e a capacidade de optar entre diferentes argumentos de maneira que possam tomar decisões em sua vida como cidadão.

Em relação às estratégias que facilitam ou dificultam a argumentação em sala de aula destacam-se as atividades nas quais o aluno participa ativamente do processo de ensino, como pode ocorrer quando se utiliza métodos investigativos e leitura de textos com discussão em sala de aula. Tais atividades tem seu alicerce na discussão e no debate entre os sujeitos do processo de ensino-aprendizagem. Esta base torna-se fundamental, pois, de acordo com Capecchi e Carvalho (2002), o professor em suas aulas deve criar espaços cooperativos para a exposição de ideias.

O professor, neste contexto, assume um papel de suma importância uma vez que a maneira com a qual intervêm na discussão em sala pode encorajar ou reprimir os alunos a participarem da atividade. Este último aspecto foi também destacado pelos licenciandos, pois citaram a necessidade do professor agir como mediador no processo argumentativo. Tal posicionamento converge com o que preconiza 
Capecchi e Carvalho (2000), que consideram a necessidade das discussões em sala de aula serem conduzidas sem se perder o foco, pois não basta deixar os alunos expressarem livremente é preciso encontrar um equilíbrio entre a livre apresentação de ideias e a atenção às questões já discutidas. Tais necessidades tornam a atuação do professor o eixo o qual irá conduzir o rumo da atividade, em que irá solicitar esclarecimentos quando necessário, relacionar falas de diferentes alunos e resgatar conceitos.

Além das estratégias, os licenciandos também mencionaram aspectos que não favorecem a argumentação, em que citam a dificuldade do professor em mediar o processo argumentativo. Aspecto também mencionado no trabalho de Capecchi e Carvalho (2002), no qual se demonstra que o professor tem dificuldade em organizar as tarefas que proporcionam discussões. Esta dificuldade vai desde incitar nos alunos a necessidade de falar e ouvir os colegas, até o direcionamento das questões a serem realizadas em aula para promover uma sistematização de ideias que possa levar a conclusões.

\subsection{Uma trajetória de reflexões sobre a prática docente dos licenciandos}

Podemos considerar que houve três momentos principais de reflexão dos licenciandos, sendo:

1) Reflexão no planejamento da ação, a qual envolveu reflexões: sobre o Estágio de Observação (Segundo momento: Estágio de Observação), sobre as reflexões teóricas quanto aos aspectos da argumentação em sala de aula (Terceiro momento: Atividades sobre Argumentação), e sobre as discussões ocorridas vinculadas a disciplina de PEQ em que os licenciandos apresentaram, compartilharam e discutiram seus projetos de regência com os demais colegas da disciplina, com a professora e a monitora (Quarto momento: Atividade de Regência);

2) Reflexão na Ação em que os licenciandos fizeram uma análise de suas ações ocorridas em sala de aula no momento em que ocorreram (Quarto momento: Atividade de Regência); 
3) Reflexão Sobre a Ação, a qual foi explicitada pela elaboração dos licenciandos do relatório de regência, na atividade de reflexão compartilhada, em que cada licenciando selecionou episódios de sua regência para discutir com os colegas e nos momentos de entrevista realizada pela pesquisadora (Quinto momento: Reflexão da prática docente).

Tecendo comentários, inicialmente no que concerne à Reflexão no planejamento da ação, percebemos que as reflexões sobre o Estágio de Observação tornaram-se importantes para a formação docente dos licenciandos. Tais reflexões não estavam diretamente relacionadas à sua ação, mas a fatores que poderiam influenciá-las e que foram identificados no período de observação.

Durante as Atividades sobre argumentação, vimos que os licenciandos puderam discutir sobre os principais aspectos que concernem ao desenvolvimento de um ambiente argumentativo em sala de aula. Compartilharam suas ideias sobre o papel da argumentação com seus colegas e responsáveis da disciplina e foram construindo uma base de conhecimento que serviu de apoio ao desenvolvimento de sua regência. Por termos trabalhado nesta etapa do projeto com estratégias de diferentes naturezas vimos que os licenciandos conseguiram observar a questão teórica na prática. Isso ficou evidente ao pedirmos que elaborassem um texto sobre as estratégias usadas pelas professoras e o processo sobre como o conhecimento científico foi sendo construído pelos alunos no vídeo sobre "Atividades de Conhecimento Físico - Física no Ensino Fundamental", antes e após a discussão teórica.

Percebemos que no texto inicial os licenciandos destacaram as atividades com um caráter descritivo e após o estudo, apresentaram relações de causa e efeito sobre as ações das professoras que observaram no vídeo. Nota-se claramente pelos resultados uma mudança de visão dos licenciandos em relação à aula observada. Esse exercício tornou-se fundamental, já que possibilitou ao futuro professor começar um contato mais próximo com a sala de aula, em uma conotação de vê-la como um ambiente de pesquisa. Desde esta perspectiva o futuro professor considera que pode estudar a sala de aula desde um ponto de vista teórico e contribuir ao desenvolvimento de teorias que visem entender, melhorar e modificar o processo de 
ensino-aprendizagem. Consideramos tal exercício como fundamental, pois como preconizado por Zeichener (1993),

[...] os professores devem ter em atenção as investigações feitas pelos terceiros. No meu trabalho com os alunos-mestres tenho, sobretudo, tentado ajudá-los a tornarem-se tanto consumidores críticos destas investigações como pessoas capazes de participarem na sua criação. (ZEICHENER, 1993, p.27)

No que concerne à elaboração do projeto de regência vimos que os artigos e as discussões teóricas desenvolvidas em sala de aula tiveram grande influência na escolha da estratégia. Porém percebemos que os licenciandos não usaram de forma acrítica as atividades estudadas na teoria, mas, ao contrário tentaram modificá-las buscando uma aproximação com a realidade em que iriam atuar, a qual tinham tido contato no momento do Estágio de Observação.

Tales, Pedro, João e Marta trabalharam com textos e usaram diferentes estratégias para criar um ambiente argumentativo em suas regências, já Beatriz optou por usar atividades experimentais, no entanto, relatou que encontrou dificuldades na elaboração de perguntas que pudessem suscitar a argumentação. Além destas estratégias, que de certa forma estavam diretamente relacionadas aos artigos discutidos na etapa de formação de conhecimentos sobre argumentação, destacamos a escolha de Rose que usou Mapa Conceitual (MC) para a promoção da argumentação.

Destacamos que o MC foi usado na disciplina de PEQ como uma ferramenta no processo de ensino - aprendizagem dos licenciandos na temática argumentação, de maneira que não foi explicitada a possibilidade do uso dessa ferramenta na promoção de ambientes argumentativos. Cabe destacar que Rose foi uma das alunas que mais sucesso teve na promoção da argumentação dos alunos nas aulas de Química.

Durante o desenvolvimento da regência os licenciandos tomaram consciência da complexidade da prática docente, no entanto, puderam também buscar alternativas para os problemas enfrentados. Foi comum o relato dos licenciandos que no momento em que estavam realizando a atividade tiveram que modificar sua prática, pensar sobre uma maneira diferente de agir e até mesmo de se darem conta da necessidade de ampliarem seus conhecimentos no que tange ao conteúdo científico 
em que estavam ensinando, apresentando vários indícios da ocorrência de reflexões nas ações.

Destacamos um momento de Reflexão na Ação, descrito na seção de resultados, em que a licencianda Rose durante sua regência não soube responder a um aluno o nome de uma família da Tabela periódica. Tal situação foi destacada pela licencianda no momento de reflexão coletiva, mas de maneira que fazia referência ao tipo de reflexão que ela fez no momento em que foi inquirida. Rose coloca que ao não saber a resposta pensou que seria melhor não responder a ter que passar uma informação errônea ao aluno. Podemos inferir que Rose passou pelas etapas preconizadas por Jalbut (2011), no processo de Reflexão na Ação, em que houve o momento de surpresa em relação a pergunta do aluno, de reflexão sobre seu conhecimento científico, de reflexão da busca da melhor atitude frente a situação e de decisão, no caso, de expor ao aluno o seu desconhecimento sobre a informação. A ação de Rose fez com que a docente colaboradora da escola a ajudasse dando a informação ao aluno.

Já num momento de Reflexão sobre a Ação vimos que o episódio acima descrito possibilitou que a licencianda se sentisse amparada em relação à ajuda da professora da escola, estreitando os laços de uma relação de professor parceiro com a estagiária. Relação que só vem a contribuir com o desenvolvimento profissional do licenciando como é destacado por Galindo (2012). Outro momento que também converge ao estreitamento de relação dos estagiários com a professora da Educação Básica aconteceu com João. O mesmo havia programado que os alunos responderiam por escrito algumas questões, porém, como a aula foi realizada na sala de vídeo a maioria não levou material. Ao perceber tal situação, João por algum tempo se viu sem saber o que fazer, até que a professora sugeriu que os alunos respondessem oralmente as questões.

Para o licenciando este apoio foi fundamental, pois mostrou a necessidade de se ter um plano extra para as ações e uma aproximação consciente do aprender do licenciando com um parceiro mais experiente, no caso, a professora de Química da escola. Tal experiência é um caminho aberto para que os futuros professores vejam 
no professor mais experiente uma fonte de conhecimento e colaboração para sua prática docente.

A Reflexão sobre a Ação se configurou a nosso ver em três momentos explícitos: um, quando os licenciandos tiveram que elaborar um relatório reflexivo de suas regências, seguindo orientações previamente entregues aos mesmos. O outro quando tiveram que apresentar nas aulas da disciplina de PEQ dois episódios de suas aulas, de maneira a compartilhar e discutir com seus colegas suas ações e o terceiro, ao serem entrevistados. Observamos que no relatório os licenciandos puderam ampliar suas reflexões buscando em muitos momentos explicações causais para as reações tanto deles no papel de docente como dos seus alunos. Tais considerações também foram encontradas nos demais momentos de Reflexão sobre a Ação.

Quanto ao compartilhamento dos episódios de ensino, os licenciandos nas aulas de PEQ, se pautaram em diferentes bases para os selecionarem. Por exemplo, Tales optou por mostrar suas ações que desencadearam um ambiente pouco argumentativo. Já João mostrou como conseguiu fazer com que um aluno que a princípio não se interessava por nada, passasse a participar das aulas.

João fez questão de mostrar o progresso que conseguiu com o aluno (que denominamos de Francisco), começando a mostrar os problemas que inicialmente teve e como ocorreu sua participação na apresentação do cartaz realizado pelos alunos sobre a temática e a redação de uma carta aos órgãos competentes se posicionando em relação à implementação de uma mineradora na região em que vive. João comenta cada episódio e apresenta qual foi sua ação e o que ela desencadeou na atitude dos alunos e de Francisco, em especial. Os licenciandos que tiveram contato no momento do Estágio de Observação com este aluno da escola básica se surpreenderam com a mudança de atitude.

Ficou clara a importância do uso do vídeo para a reflexão dos licenciandos, todos tiveram um olhar diferenciado sobre suas regências. Quanto a esse aspecto Garrido e Carvalho (1999) apontam que a gravação das aulas dos professores colabora na dinâmica de discussão e favorecem a relação de teoria e prática, na medida em que as ações dos professores mostradas no vídeo precisam ser defendidas podendo incorporar aspectos teóricos. 
Tivemos reflexões dos licenciandos de diferentes naturezas: as que estavam relacionadas diretamente a sua ação como docente, como a sua opção pelas estratégias utilizadas, como reflexões que envolviam o contexto escolar de uma maneira ampla. Vimos os licenciandos refletirem sobre aspectos do ambiente escolar que de forma direta ou indireta influenciaram na sua ação docente. Exemplo desses elementos é o fato dos licenciandos Pedro e Tales que ao tentarem realizar uma aula prática com os alunos se depararem com a porta do laboratório sem maçaneta, o que impossibilitou a aula experimental. Temos também Marta que aponta a dificuldade que teve em conseguir a chave da sala de informática da escola, considerando neste caso, que a mesma havia feito reserva prévia. Esses e outros entraves relacionados a questões de organização e infraestrutura escolar foram considerados pelos licenciandos como elementos dificultadores da ação docente.

Devemos levar em consideração que a maneira como o sistema escolar do contexto em que esta pesquisa foi desenvolvida está organizado dificulta em certos aspectos a ação docente. Nesse sistema, muitas vezes o professor acaba por ter que lecionar em diferentes escolas, possui longas jornadas de trabalho, as aulas para uma mesma sala nem sempre são no formato duplo, o que implica que as ações devem ser realizadas em aulas de 50 minutos cada, dentre outros fatores. Quanto a isso, identificamos falas dos próprios licenciandos que ao realizarem o Estágio de Observação perceberam que o tempo efetivo de aula variava muito e que geralmente os 15 minutos iniciais de cada aula eram utilizados para que a professora conseguisse ter a atenção dos alunos.

Vemos que tais aspectos foram destacados pelos licenciandos como algo que dificulta a ação docente, no entanto, não os impediram de desenvolverem suas atividades. Em relação a esses aspectos encontramos convergências em Garrido (2010), que discorre sobre trabalhos realizados por seu grupo de pesquisa envolvendo projetos de pesquisa-ensino colaborativa com professores em atividade. A autora relata que encontrou dois tipos de dificuldades, a saber:

[...] uma delas é de ordem institucional, e diz respeito aos conflitos e contradições próprios à organização escolar; a outra é inerente à natureza complexa, criadora e singular do mundo da prática e da pesquisa sobre a prática docente (GARRIDO, 2010, p. 106). 
Ainda como produto da sua Reflexão sobre a Ação, encontramos nos licenciandos um espírito de busca de um entendimento melhor sobre o que compõe a prática docente e como poderiam melhorá-la. Foi comum ouvirmos dos licenciandos explicações de suas ações e reações dos alunos. A título de exemplo, destacamos o licenciando Tales, o qual apresentou que no dia da atividade em que iria trabalhar a estratégia argumentativa, estava de mau humor, não tinha vontade de falar e o fato de ser a primeira aula com início às sete horas da manhã o fez chegar desanimado. Tales percebeu que sua postura influenciou diretamente os alunos no que tange a participação na aula e no interesse pela atividade.

Tales tomou consciência de que o insucesso da sua atividade deveu-se em grande parte da sua atitude como docente. O fato de não ter logrado uma aula totalmente argumentativa não invalidou, a nosso ver, a riqueza da experiência, já que a tomada de consciência por parte do licenciando foi fundamental para seu crescimento profissional. Considerações que ampliamos também para a Beatriz e Pedro.

Já Marta em suas primeiras reflexões é taxativa ao considerar que o insucesso de sua regência está vinculado diretamente aos alunos da Educação Básica. Garrido e Carvalho (1999), encontraram resultados semelhantes em um trabalho realizado com alunos da licenciatura em Física. As autoras viram que inicialmente para justificar suas dificuldades de implementar atividades de natureza construtivistas os licenciandos apontavam deficiências nos alunos e que depois suas questões versavam no interesse em saber desenvolver de forma efetiva as atividades.

Além disso, concordamos com Archila (2012), de que o sucesso das atividades argumentativas não está atrelado apenas à seleção de estratégias adequadas, mas sobretudo, ao discurso construído em torno das mesmas. Este fato ficou evidente nas atividades do licenciando Tales, o qual selecionou uma estratégia que a princípio poderia suscitar a argumentação durante a aula, mas que sua ação docente inviabilizou o sucesso da ação.

Em nosso trabalho percebemos que no decorrer das reflexões da Marta realizadas de forma coletiva, a mesma foi alterando sua concepção de que o motivo principal de sua dificuldade foi em sua gênese a falta de interesse dos alunos pelas 
atividades. João no momento em que Marta está apresentando esta ideia torna-se contrário à justificativa e acrescenta que na verdade os alunos não estão acostumados com atividades de natureza diferenciada, ação que a faz refletir.

Durante diferentes momentos da trajetória dos licenciandos, no que concerne a sua formação na disciplina de Prática do Ensino de Química, pudemos identificar situações em que os mesmos tiveram colaboração de diferentes sujeitos envolvidos no processo. Tais colaborações ocorreram tanto numa via em que eles iam procurar o auxílio com os responsáveis pela disciplina, a professora de Química da escola e seus pares, como numa via em que a disciplina PEQ proporcionou momentos de colaboração. Um desses momentos ocorreu na atividade de Estágio de Observação em que os licenciandos tinham que postar no blog da disciplina suas impressões acerca das experiências vividas, as quais eram compartilhadas e acrescentadas pelos demais licenciandos e comentadas pela professora e monitora da disciplina.

Ainda como espaço de reflexão, os licenciandos tinham abertura em todas as aulas da disciplina PEQ para apresentarem suas inquietações em relação ao processo de ensino-aprendizagem, mas em algumas, em específico, está abertura era explicitada pela docente da disciplina. Nestes momentos, os licenciandos tinham consciência de que havia ali um espaço em que poderiam compartilhar com os demais suas angústias, sucessos, dificuldades, dúvidas e colaborar no processo evolutivo docente de seus colegas. Destacamos o fato de que para os licenciandos, estes momentos configuravam-se como de extrema riqueza e de edificação.

Como todas as regências foram gravadas, foi comum após as aulas os licenciandos construirem um diálogo conosco. Em alguns casos a conversa pautavase na necessidade do licenciando em obter uma aprovação da sua regência por nossa parte. No entanto, na maioria das vezes o diálogo permeava os aspectos que poderiam ser melhorados na atuação do licenciando como docente. O vídeo (gravação das regências) possibilitou que os licenciandos focassem ainda mais sua análise no caminho ao qual introduziram e desenvolveram as atividades de natureza argumentativa. Além disso, no momento em que estavam compartilhando seus episódios de ensino, os licenciandos usavam das cenas para justificarem suas ações, sejam elas desde uma perspectiva de sucesso na argumentação, como de dificuldade. 
Como exemplo, podemos citar Tales o qual destaca no vídeo que sempre ficava na mesma posição na frente da sala, o que juntamente com outros fatores dificultou um maior envolvimento com os alunos.

Assim, foram fundamentais os momentos em que os licenciandos tiveram um espaço para sanarem dúvidas, dividirem suas inquietações e terem contribuições dos diferentes participantes do processo, sendo seus colegas da licenciatura, a docente responsável pela disciplina de Prática do Ensino de Química, a monitora, a professora de Química da Escola Básica e os demais professores que compunham o quadro escolar.

Observamos que os alunos estiveram imersos em um ambiente no qual tiveram espaços para experimentarem, cometerem erros, tomarem consciência dos seus equívocos, refletirem sobre os problemas educacionais e sobre seu papel fundamental como mediador do processo de ensino-aprendizagem numa vertente argumentativa, conforme nos apresenta Penteado (2010) para uma formação docente com característica do modelo da Racionalidade Prática. Outro fator chave foi o fato de assumirem sua prática como um momento de investigação e desenvolvimento profissional docente em que as dimensões prática e teórica caminharam de forma colaborativa (ARAUJO, 2009; PEREIRA, 2006 e GHEDIN, 2001).

Buscamos ainda nesta dinâmica de formação que os licenciandos pudessem incorporar elementos da sua reflexão também sobre o ambiente social assumindo um papel de investigador da sua prática e aspectos da realidade social. Além disso, que pudessem suscitar nos alunos da escola básica a capacidade de interpretação e atuação crítica na sociedade, oriundo da articulação entre o conhecimento científico abordado na escola e sua vida cotidiana, como defende Abib (1996).

Entendemos que desenvolver nos licenciandos o desejo de trabalhar com atividades argumentativas em sala de aula e entender os benefícios da mesma à formação do estudante para uma atuação na sociedade apresenta elementos da Racionalidade Crítica. Tais elementos podem contribuir significativamente para a realidade social já que é de conhecimento que a argumentação também pode colaborar ao desenvolvimento de um cidadão que venha atuar de forma crítica na sociedade em seus diferentes âmbitos. Além disso, o trabalhar em um ambiente 
argumentativo contribui na busca de uma educação igualitária e na diminuição da desigualdade social (BATISTA, 2009).

Com um foco mais direcionado ao aspecto da argumentação destacamos a natureza diferenciada das reflexões dos licenciandos ocorridas dentro dos momentos de Reflexão sobre o planejamento da ação, Reflexão na Ação e Reflexão Sobre a Ação. Percebemos movimentos dos licenciandos em transporem as questões teóricas concernentes à argumentação discutidas durante a disciplina de Prática do Ensino de Química para sua ação em sala de aula. Tal transposição não foi feita de maneira literal, mas eles conseguiram se apropriar de aspectos fundamentais da teoria e a adaptaram a sua prática na busca da criação de instrumentos da investigação de sua regência.

Além disso, vimos o movimento dos licenciandos em criarem indagações sobre como melhorar sua prática e de como poderiam ter utilizado mais da teoria em sua prática docente. Identificamos estes aspectos em todos os licenciandos nos diferentes momentos das atividades. Por exemplo, Beatriz destaca muito esses aspectos de mudança na sua apresentação da reflexão da regência, no seu relatório e na entrevista. Já Marta, além destes momentos também o fazia em diferentes oportunidades logo após a regência e durante a aula da disciplina de Prática do Ensino de Química.

Quanto a isso Penteado (2010) nos coloca que o uso de conhecimentos das ciências humanas e dos demais campos devem ser ministrados de maneira teórico/prática em que esses conhecimentos, no papel de instrumentos intelectuais, servirão de base à criação dos instrumentos de investigação, de propostas de intervenção didática que venham a superar problemas docentes e de reflexões sobre os processos desenvolvidos e descobertas realizadas. Isso possibilita que o professor transite da teoria a prática docente e desta à teoria.

Identificamos o referido movimento nos licenciandos que usaram da teoria, em especial, no que concerne a argumentação para desenvolver sua regência, mas também fizeram o movimento de as utilizarem para analisarem sua prática e, em muitos casos, para observarem a existência ou não da criação de um ambiente argumentativo. Podemos citar Tales que usou do modelo de Toulmin para elaborar 
sua estratégia argumentativa, em que se preocupou em fornecer materiais que pudessem servir de base, justificativa e refutação para os alunos chegarem as conclusões.

Os momentos de compartilhamento da experiência possibilitaram aos licenciandos tomarem consciência de que muitos problemas que encontraram na sua regência como a indisciplina dos alunos, a dificuldade em conduzir atividades de natureza argumentativa, entre outros, também eram comuns com seus colegas. E puderam ainda ver como cada um superou ou não os obstáculos encontrados. Este momento se caracterizou como uma oportunidade dos futuros professores refletirem sobre os problemas e a dinâmica gerada por sua ação cotidiana na busca de um paradigma da prática reflexiva (SCHÖN, 2000; ABIB, 1996).

Ainda em relação à reflexão dos licenciandos quanto às atividades desenvolvidas ao longo da disciplina PEQ no que tange a temática da argumentação, vimos um grande aproveitamento das mesmas desde a elaboração, implementação e reflexão da regência até a sua projeção futura na ação docente. Foi unânime e consciente por parte dos licenciandos que as atividades tanto as teóricas como as práticas e os momentos de compartilhamento de informações criaram um ambiente saudável de aprendizagem no que tange a sua formação de base de conhecimentos relativos à argumentação.

Além disso, vemos expresso nas falas dos licenciandos que a oportunidade de vivenciarem um processo de elaboração de atividades argumentativas foi um momento de grande aprendizagem à sua futura atuação docente, pois forneceram o primeiro passo para uma mudança de paradigma do modelo tradicional de ensino. Podemos citar Marta de exemplo que imaginava que desenvolveria uma aula de "Química redondinha", em que desenvolveria o tema e depois veria se todos aprenderam. Ao passar pela dinâmica de formação ampliou sua visão de ensino e foi uma das licenciandas que mais refletia sobre suas ações.

Podemos fazer uma comparação dos resultados acima com a posição de Archila (2012) que considera que a qualidade dos argumentos dos estudantes está condicionado ao estímulo que recebem para envolver-se numa prática de discussão reflexiva. Assim, se temos professores capacitados a desenvolverem habilidades 
argumentativas, certamente conseguirão criar ambientes que possam promover a motivação de seus alunos.

Vemos também que estas contribuições à formação dos licenciandos não estão limitadas a questões sobre argumentação, mas a uma ampliação de seus saberes do processo de ensino-aprendizagem. Beatriz é uma das licenciandas que expressa tal movimento, revelando que a mesma aprendeu... "olhar de outra maneira o conteúdo da disciplina que eu for ministrar porque não precisa ser transmitida da forma que está no livro, pode ser transmitida de outra forma tentando trazer os alunos a participarem".

Os licenciandos puderam também alterar a concepção de que os alunos não participam de atividades, ideia oriunda em certa parte do Estágio de Observação, em que os licenciandos presenciaram cenas de desinteresse dos estudantes. Vivenciaram uma aprendizagem da escolha da estratégia para trabalhar a argumentação de maneira que pudessem ter um olhar crítico em relação às mesmas antes e após a sua ação em sala de aula. Além disso, compartilharam suas experiências com seus colegas em uma perspectiva construtiva do aprender a docência.

Em relação, a como os licenciandos se sentiram ao terem que desenvolver atividades que saiam do modelo tradicional e abordavam um ambiente numa perspectiva argumentativa tivemos que alguns se sentiram desconfortáveis e com receio de não conseguirem sair do modelo tradicional de ensino. Vimos, porém, que ao serem indagados se utilizariam novamente atividades desta natureza todos se mostraram favoráveis sendo que, em alguns casos, apresentaram o que mudariam em uma próxima oportunidade. Quanto às dificuldades encontradas ao desenvolver atividades de natureza argumentativa os destaques dos licenciandos foram no sentido de:

a) não encontrarem modelos de perguntas que poderiam ser feitas aos alunos em relação à atividade experimental,

b) falta de experiência dos licenciandos em vivenciarem e desenvolverem atividades de natureza argumentativa,

c) falta de experiência dos alunos da Educação Básica em participarem de atividades argumentativas, 
d) resistência do próprio licenciando em considerar o desenvolvimento de atividades que saem do padrão tradicional,

e) dificuldade de comunicação com os estudantes,

f) falta de hábito de leitura e interpretação de textos por parte dos alunos da escola básica,

g) falta de materiais, como textos, com caráter de modelo numa vertente argumentativa para que pudessem ser utilizados em sala de aula e

h) encontrar uma atividade que agrade os alunos do Ensino Médio.

Identificamos que as dificuldades dos licenciandos permearam quatro campos:

a) falta de materiais mais direcionados que poderiam servir de guia aos professores para desenvolverem atividades de cunho argumentativo,

b) a sua própria falta de experiência em promover situações argumentativas,

c) do seu papel como mediador do processo argumentativo,

d) da falta de preparo e desinteresse dos alunos da Educação Básica em participar das aulas.

Uma vez desenvolvida a atividade argumentativa os licenciandos utilizaram diferentes critérios para analisar a promoção de um ambiente argumentativo em suas regências. Beatriz considerou a participação dos alunos na atividade a qual considera que ficou a desejar, o que atribui em alguns aspectos aos alunos, e em parte a sua deficiência quanto ao seu papel de mediadora do processo. Similar critério foi usado por Rose a qual se baseou na participação efetiva dos alunos com questões que geravam discussões ao confeccionarem o mapa conceitual e por João que obteve grande participação dos alunos durante as atividades.

Já Marta, buscou encontrar nas falas dos alunos os elementos do modelo de Toulmin e percebeu que nem sempre eles estavam presentes o que a levou a considerar que em suas aulas os alunos argumentaram de maneira comedida. Pedro também buscou os elementos do referido modelo nas falas dos alunos e de forma 
similar concluiu a baixa argumentação dos alunos em suas aulas. Tales além de usar o modelo para analisar a argumentação o utilizou como base para elaborar a atividade e concluiu que a argumentação não foi suscitada da maneira como esperava atribuindo tal resultado em grande parte a sua ação como docente.

Tais resultados levam a concluir que as bases de análises dos licenciandos centraram-se no grau de participação dos alunos nas atividades e na busca dos elementos de Toulmin na análise dos argumentos. Em uma busca na literatura encontramos que critérios similares são reportados em pesquisas que visam a um ambiente argumentativo em sala de aula, por exemplo, em Sá e Queiroz (2009), as autoras utilizaram o modelo de Toulmin para estudarem a argumentação de alunos de um curso de Química. Buscando sintetizar aspectos de mudança dos licenciandos ao longo de sua trajetória pela disciplina de PEQ, no que concerne a temática argumentação, elaboramos o esquema da Figura 4. Destacamos que está é uma visão do contexto em uma perspectiva geral e não específica para cada licenciando.

Retomando inicialmente aos resultados sobre as concepções dos licenciandos sobre argumentação, temos que as mesmas aproximavam-se em muito de uma atividade social, intelectual e verbal, na qual se busca obter a aprovação de um auditório sobre um determinado assunto por meio de argumentos que justificam ou refutam uma ou várias opiniões como defendem Vieira e Nascimento (2009b). Tal concepção não se mostrou alterada ao longo das atividades desenvolvidas, no entanto, podemos ver, analisando o esquema (Figura 4), uma diferença significativa na concepção das estratégias que podem ser utilizadas em salas de aula para promover um ambiente numa perspectiva argumentativa.

Destacamos que, inicialmente, Rose, Marta e Pedro apresentaram que no papel de alunos, eles argumentam para verificar conhecimentos aprendidos, dentro de uma conotação retórica. No entanto, os mesmos escolheram estratégias que vão em sentido oposto a essa conotação. Rose escolheu usar mapa conceitual, ferramenta que preza pelo desenvolvimento cognitivo do aluno, Marta optou por uma atividade em que o produto final seria uma relação de aspectos em uma forma priorizada o qual deveria ser realizado em conjunto e discutido entre os pares, já Pedro tentou usar oficina de leitura para que os alunos pudessem participar de forma colaborativa 
num contexto argumentativo. Percebemos que estes licenciandos buscaram alternativas que saíssem do contexto em que eles, como alunos, segundo suas óticas, argumentam.

As concepções iniciais dos licenciandos quanto ao uso de estratégias argumentativas em sala de aula estão relacionadas ao seu auxílio no processo de aprendizagem dos conceitos, na formação do cidadão crítico e na identificação das dificuldades e conhecimento prévio dos alunos. Após passarem por todo o processo da elaboração, implementação e avaliação das regências, os mesmos, continuam com estas concepções, porém, acrescentaram novas, considerando também que a argumentação,

a) auxilia na criação de um hábito da leitura de forma crítica;

b) aproxima alunos e professores;

c) colabora na formação do cidadão capaz de enfrentar a sociedade;

d) contribui ao desenvolvimento do conhecimento científico;

e) possibilita aos alunos melhorarem sua habilidade de expressão oral;

f) amplia o vocabulário e a visão dos alunos em relação a determinado assunto, mostrando os diferentes posicionamentos que se pode ter de um mesmo aspecto e sua influência direta na sociedade;

g) colabora no desenvolvimento cognitivo do aluno tornando-o uma pessoa mais culta, de melhor comunicação, mais crítica;

h) auxilia o professor a direcionar a aprendizagem dos alunos;

É evidente a ampliação do papel da argumentação no contexto de sala de aula. Destacamos, portanto uma evolução das concepções dos licenciandos em um campo mais complexo e profundo, no qual além de explicitarem as contribuições também apontam os motivos dessas. Tais mudanças atribuímos ao conjunto de atividades desenvolvidas com os licenciandos, desde a parte teórica em que puderam ter contato com os aspectos de pesquisa sobre a temática até sua ação no estágio que possibilitou a elaboração de conhecimentos práticos em associação com elementos teóricos sobre o uso de atividades argumentativas em sala de aula. 
Quanto às estratégias potencialmente promotoras de um ambiente argumentativo temos que inicialmente os licenciandos consideravam que estas deveriam ser pautadas na participação ativa dos alunos, porém não apresentam estratégias concretas a serem desenvolvidas. Já numa visão reflexiva posterior dos licenciandos quanto às estratégias que eles usaram para promover a argumentação, podemos identificá-las e inclusive encontrar os motivos que os levaram às suas escolhas. A seguir, destacamos cada uma delas e, em alguns casos, as explicações concernentes às mesmas:

a) metodologia de Laboratório Aberto. Nesta estratégia, as perguntas realizadas buscavam identificar as hipóteses dos alunos durante a realização de um experimento sobre a temática;

b) produção de textos com necessidade de posicionamentos críticos sobre aspectos sociocientíficos;

c) debate com dinâmicas em grupos pequenos e depois com toda a sala;

d) discussão com base em aspectos do cotidiano suscitada pelo licenciando com a colaboração dos alunos;

e) construção de mapas conceituais em que a eleição dos conceitos suscitaria uma discussão de natureza argumentativa;

f) discussão de afirmativas apresentadas pelo licenciando em que os alunos tinham que apresentar justificativas para seu posicionamento. Nesta caso, o licenciando forneceu o Dado e os alunos com base no Conhecimento Básico oriundo da aula teórica e do texto de apoio deveriam construir as conclusões. Vemos neste último uma busca da utilização do modelo de Toulmin para o desenvolvimento da atividade.

Atribuímos estas mudanças observadas nas concepções dos licenciandos a um trabalho em conjunto que se compôs de discussões numa perspectiva argumentativa dos mesmos com os demais envolvidos na disciplina de PEQ sobre os aspectos teóricos e práticos concernentes a argumentação. Percebemos também que o grupo de discussão representou um papel fundamental na edificação dos saberes de cada licenciando. 
Em um momento de reflexão sobre quais os conhecimentos necessários a um professor para atuar com atividades argumentativas, percebemos uma clara e significativa mudança ao longo do processo. Antes de participarem das atividades os licenciandos consideravam que o professor deveria ter um preparo, mas não especificam que tipo de conhecimento seria requerido do mesmo. Já após terem vivenciados o movimento cíclico de teoria - prática - teoria é nítida a ampliação de suas concepções na busca de apresentar elementos necessários ao desenvolvimento de um ambiente argumentativo em sala de aula.

Os licenciandos apresentam a necessidade de o professor saber argumentar; conduzir a dinâmica com os alunos; ter os conceitos de argumentação bem definidos; conhecer os elementos que definem um argumento, em especial, o modelo de Toulmin; ter domínio sobre o conteúdo a ser ensinado; ter conhecimentos de atividades que venham a propiciar um ambiente numa perspectiva argumentativa; conhecer as potencialidades e limites das atividades a serem usadas;se preparar para a realização da atividade; saber buscar informações em fontes confiáveis e manter um contato com a universidade na busca de construir um elo entre os dois universos (universidade e escola) de modo a contribuir e receber apoio da academia.

Fica evidente o movimento cíclico, de ampliação, que os licenciandos fizeram em relação às teorias que concernem à argumentação e a sua prática em sala de aula. Tal movimento possibilitou que os mesmos baseassem sua prática em um arcabouço conceitual e pudessem entender seus resultados desde uma perspectiva teórica e prática, em que assumiram sua regência, em certa medida, como um espaço de pesquisa da sua própria prática docente. Além disso, vimos claramente a contribuição significativa da participação de ações coletivas em que os licenciandos puderam ter momentos de troca com seus pares, com profissionais mais experientes e com pesquisadores da universidade. Esta combinação veio a contribuir para uma ação mais consciente da atual e futura prática docente dos licenciandos.

Vimos também no decorrer do desenvolvimento das atividades uma mudança significativa na concepção dos licenciandos sobre a implementação de atividades diferenciadas. Considerando como exemplo a licencianda Marta, percebemos que ao explicitar suas considerações sobre o Estágio de Observação destaca o fato de chegar 
à sala de aula e não encontrar as carteiras posicionadas em fileiras como em sua época de estudante da Educação Básica, o que lhe causou estranhamento. A mesma sequer considerou que tal disposição poderia estar vinculada a uma dinâmica de atividade. Já em sua regência, numa perspectiva argumentativa, a mesma utilizou dinâmicas em que as disposições das carteiras saíam do modelo tradicional e considerava um modelo em que os alunos teriam um ambiente mais propício para discutirem com o professor e com os colegas. 
Momento I: Concepções antes

da dinâmica de formação

\section{Momento II: Concepções durante e/ou após a dinâmica de formação}

\begin{tabular}{|c|c|c|}
\hline $\begin{array}{l}\text { Elementos } \\
\text { Argumentação }\end{array}$ & Conotação retórica & Conotação dialógica \\
\hline $\begin{array}{l}\text { Função da argumentação } \\
\text { em sala de aula }\end{array}$ & $\begin{array}{l}\text { Facilitar a aprendizagem } \\
\text { Formar cidadão crítico } \\
\text { Identificar conhecimento prévio } \\
\text { dos alunos }\end{array}$ & $\begin{array}{l}\text { Facilitar a aprendizagem } \\
\text { Formar cidadão crítico } \\
\text { Identificar conhecimento prévio dos alunos } \\
\text { Desenvolver habilidades de expressão } \\
\text { Auxiliar na criação de hábito de leitura crítica } \\
\text { Aproximar alunos e professores } \\
\text { Contribuir ao desenvolvimento do conhecimento científico } \\
\text { Melhorar a habilidade de expressão oral de alunos e professores } \\
\text { Ampliar o vocabulário de alunos e professores } \\
\text { Ampliar a visão de Ciências Exatas no cotidiano dos alunos }\end{array}$ \\
\hline $\begin{array}{l}\text { Estratégias promotoras } \\
\text { da argumentação em sala } \\
\text { de aula }\end{array}$ & $\begin{array}{l}\text { Atividades que tenham } \\
\text { participação ativa dos alunos }\end{array}$ & $\begin{array}{l}\text { Metodologia de Laboratório Aberto } \\
\text { Produção de textos com necessidade de posicionamentos crítico sobre aspecto sóciocientífico } \\
\text { Debate com dinâmicas em grupos pequenos e depois com toda a sala } \\
\text { Discussão com base em aspectos do cotidiano dos alunos } \\
\text { Construção de mapas conceituais } \\
\text { Discussão com posicionamentos críticos dos alunos }\end{array}$ \\
\hline $\begin{array}{l}\text { Saberes necessários a um } \\
\text { professor para } \\
\text { desenvolver atividades } \\
\text { argumentativas }\end{array}$ & Não definem & $\begin{array}{l}\text { Saber argumentar } \\
\text { Saber conduzir a dinâmica com os alunos } \\
\text { Ter os conceitos de argumentação bem definido } \\
\text { Conhecer os elementos que definem um argumento } \\
\text { Conhecer as potencialidades e limites das atividades a serem usadas } \\
\text { Estar preparado para a realização da atividade } \\
\text { Saber buscar informações em fontes confiáveis } \\
\text { Manter contato com a universidade na busca de manter elo entre dois universos de maneira a } \\
\text { contribuir e receber apoio da academia. }\end{array}$ \\
\hline
\end{tabular}

FIGURA 4: RESUMO DAS CONCEPÇÕES DOS LICENCIANDOS SOBRE ASPECTOS DA ARGUMENTAÇÃO EM SALA DE AULA EM DOIS MOMENTOS CONFIGURADOS COMO MOMENTO I - CONCEPÇÕES ANTES DE VIVENCIAREM AS ATIVIDADES DA DINÂMICA DE FORMAÇÃO VINCULADA A DISCIPLINA DE PRÁTICA DO ENSINO DE QUÍMICA E MOMENTO II APÓS PARTICIPAREM DA DINÂMICA. 
Percebemos a importância que os momentos reflexivos tanto de maneira individual como de forma conjunta trouxeram ao desenvolvimento dos futuros professores em sua prática docente. Vimos os licenciandos passarem por diferentes etapas de reflexão sendo a perplexidade, a elaboração, a geração e a comparação de hipóteses e a implementação da ação. Como busca de fechamento da discussão elaboramos o esquema (Figura 5), no qual expressamos os movimentos por nós identificados ao longo de todo o processo. Identificamos três movimentos principais de reflexão, sendo:
a) Reflexão no planejamento da ação
b) Reflexão na ação
c) Reflexão sobre a ação

Percebemos que os três movimentos principais de reflexão estão em um ciclo, os quais fornecerão a base ao desenvolvimento dos Saberes de Argumentação Docente. Identificamos que o movimento de Reflexão no planejamento da ação colabora com a Reflexão na ação e sobre a ação, pois, sabendo os objetivos iniciais de cada atividade é possível no momento da ação, e depois dela, realizar uma análise consistente relacionando resultado com objetivo. A Reflexão na ação e sobre a ação dá subsídios para que novas reflexões no planejamento em ações docentes futuras sejam realizadas. Dando embasamento a estes movimentos temos os aspectos teóricos e os práticos que fundamentam os processos de ensino-aprendizagem, numa perspectiva de desenvolvimento de um ambiente argumentativo e das ações/reflexões compartilhadas dos licenciandos. 


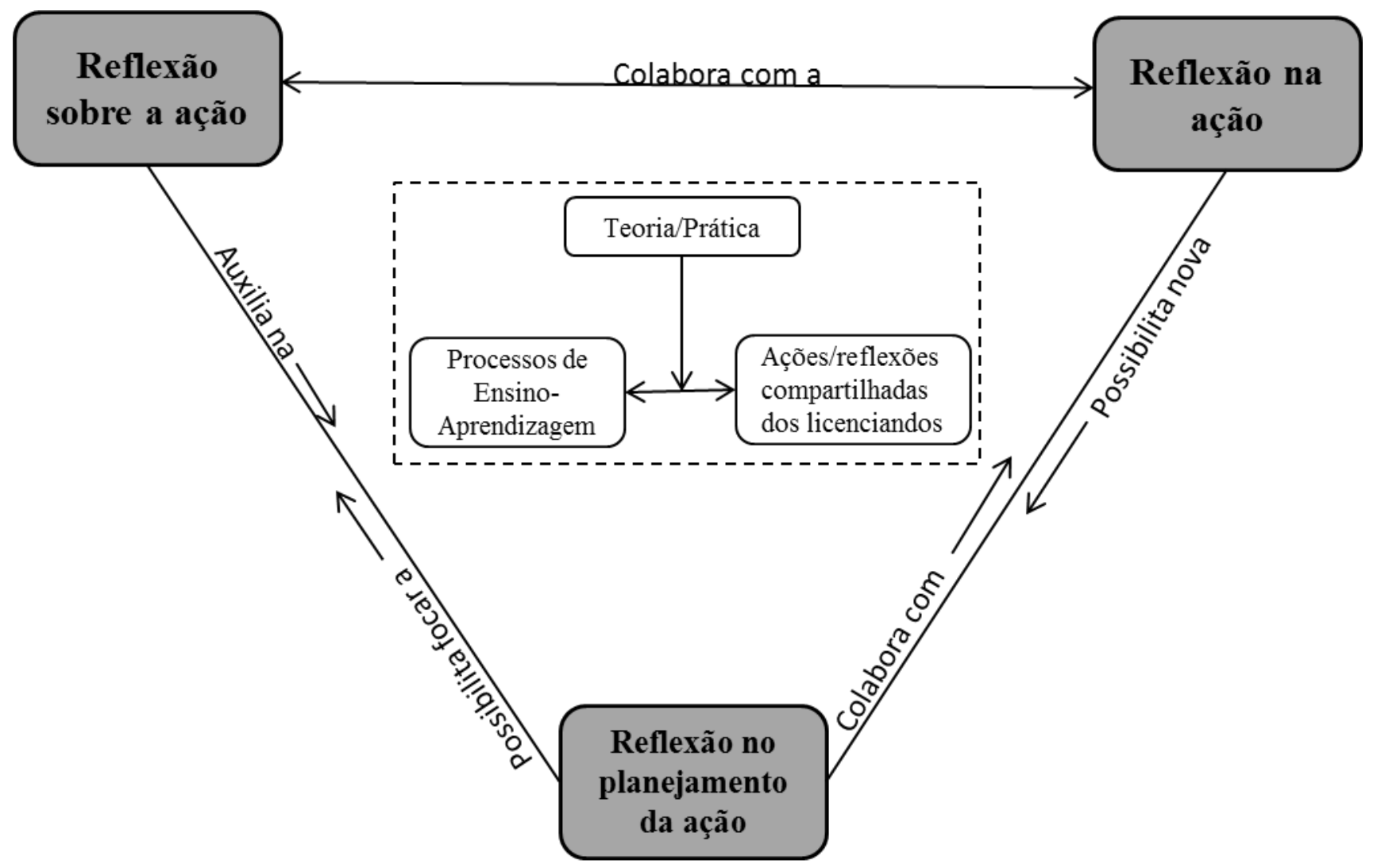

FIGURA 5: ESQUEMA DOS MOVIMENTOS DE REFLEXÃO IDENTIFICADOS AO LONGO DAS ATIVIDADES DESENVOLVIDAS PELOS LICENCIANDOS. 


\subsection{O desenvolvimento e mobilização de Saberes de Argumentação Docente}

$\mathrm{O}$ fato dos licenciandos terem desenvolvidos saberes concernentes à ação docente numa perspectiva argumentativa é de grande importância para seu desenvolvimento profissional. Consideramos que os SADs foram desenvolvidos e/ou mobilizados a partir dos movimentos reflexivos que os licenciandos vivenciaram ao longo de todo o processo de elaboração da regência numa perspectiva argumentativa. Categorizamos com base em Schön (2000) estes momentos em: Reflexão sobre o planejamento da ação, Reflexão na Ação e Reflexão Sobre a Ação.

Percebemos que ao longo do processo os licenciandos foram alterando seus saberes e aprendendo a planejar atividades que pudessem vir a possibilitar em sala de aula um ambiente argumentativo. Como exemplo, citamos o caso de Rose que no começo tinha seu plano de aula sem um direcionamento claro de como conduziria as atividades. Na segunda vez em que apresentou seu projeto de regência, determinou que usaria mapa conceitual, no entanto, as outras atividades a serem desenvolvidas não tinham sido definidas. Esse movimento de pensar as atividades, numa busca de optar pela estratégia que mais se adequava a promoção de um ambiente argumentativo contribuiu para o desenvolvimento de saberes.

Outro benefício da reflexão sobre o processo que os licenciandos desenvolveram está atrelado às reflexões que fizeram no momento de sua ação. Tais reflexões propiciaram em alguns momentos que mudassem sua postura ainda em sala de aula, e em outros casos, que refletissem sobre possíveis mudanças futuras. Destacamos que muitas das reflexões foram explicitadas pelos licenciandos após suas regências, mas os mesmos deixaram claro o que pensaram no momento em que estavam em sala de aula. Ainda tomando Rose como exemplo, vemos que a mesma ao passar por uma situação em que não soube responder uma pergunta do aluno se coloca numa posição em que considera a importância de conhecer os conteúdos a serem ensinados, principalmente em uma atividade argumentativa em que a abertura aos alunos é maior.

Consideramos que ao refletirem sobre todo o processo desenvolvido, os licenciandos puderam ter uma maior conscientização da importância de suas ações no processo de ensino-aprendizagem e um entender de como poderiam modificá-las 
visando ações docentes futuras. Além disso, o fato dos licenciandos compartilharem esse movimento de reflexão sobre a ação com os demais sujeitos envolvidos em sua formação na disciplina de Prática do Ensino de Química, possibilitou verem suas dificuldades em muitos casos são de igual grau que a dos outros licenciandos. Além disso, em algumas situações mudaram sua concepção sobre sua reflexão e os sujeitos, juntos, em alguns casos, chegaram a conclusões de como poderiam melhorar a prática docente.

Percebemos que o Saber de Argumentação Docente dos Fins Educacionais foi em muitos momentos o direcionador dos licenciandos na elaboração, implementação e análise da atividade de natureza argumentativa. Como exemplo, destacamos João que com o objetivo de possibilitar o desenvolvimento e/ou aprimoramento de posicionamentos críticos dos alunos conduziu uma atividade em que estes tinham que se posicionar criticamente quanto à instalação de uma mineradora na região em que vivem. Neste momento também encontramos indícios do SAD Sociocientífico.

A escolha desta estratégia feita por João está diretamente atrelada à concepção que tem sobre os benefícios de trabalhar com atividade desta natureza, a qual pode possibilitar o desenvolvimento de um cidadão crítico na sociedade, num movimento dos alunos em extrapolarem os conceitos científicos ao seu cotidiano. Habilidade também preconizada por Jiménez-Aleixandre (2010) e Caamaño (2010), como um dos benefícios decorrentes do uso de atividades argumentativas em que o cidadão deve ter uma opinião independente, uma capacidade de refletir sobre a realidade da sociedade e que possa intervir na sua melhora.

Destacamos a relação direta do SAD dos Fins Educacionais com o SAD Relativo às Estratégias, pois foi com base no primeiro que muitos licenciandos escolheram e desenvolveram as estratégias com os alunos. Atrelado ao SAD Relativo às Estratégias identificamos mais cinco saberes, sendo: SAD de Gerenciar Ideias promovendo Justificação; SAD Promover Feedback; SAD de Conhecer os Elementos do Argumento; SAD de Gerenciar ideias Instigando Questionamentos e SAD da Análise do Argumento. É verdade que os referidos saberes foram identificados em menor frequência, pois nem todos os licenciandos os expressaram de forma que pudéssemos caracterizar as ideias por eles explicitadas como saberes. 
No entanto, percebemos em sala de aula e nas estratégias escolhidas pelos futuros professores uma busca por criarem ambientes propícios à explicitação e justificação de diferentes posicionamentos, de possibilitarem que os alunos tivessem acesso aos dados e conhecimento básico. Tais aspectos possibilitariam aos alunos um embasamento para construírem argumentos mais complexos e elaborados, o que ajudaria na elaboração dos argumentos uma vez que estariam abordando os elementos constituintes de um argumento como definem Solbes, Ruiz e Furió (2010) e Sá e Queiroz (2009).

Outro saber que identificamos na nossa pesquisa foi SAD Disciplinar, porém esse não foi identificado na fala dos licenciandos. Embora, tenha ocorrido este fato defendemos a sua importância, pois o domínio do conteúdo torna-se fundamental no processo argumentativo, de maneira a dar mais confiança ao professor para trabalhar com atividades argumentativas em sala de aula. Além disso, extrapolando para a aplicação de atividades de diferentes naturezas torna-se fundamental que o professor tenha um conhecimento sólido sobre o assunto, para que possam sentir-se seguro em atuar com diferentes estratégias, principalmente as que possibilitam uma ação mais ativa do aluno no processo de ensino-aprendizagem.

Percebemos ao longo do estudo que os Saberes de Argumentação Docente são articulados entre si no sentindo de que formam uma rede que possibilita o desenvolvimento de um ambiente argumentativo. Percebemos que os saberes não só estão atrelados ao sucesso da ação docente, mas também à construção de um ensinar reflexivo. Os saberes dos licenciandos foram se constituindo e/ou modificando a partir de reflexões na prática, sobre a prática e no planejamento da mesma. Em muitos casos para desenvolver os saberes foi necessário que os licenciandos fizessem uma reflexão crítica sobre diferentes aspectos do processo do planejamento, implementação e análise da sua prática docente em uma perspectiva argumentativa. E, para se darem conta de seus saberes tiveram que refletir assumindo uma postura crítica sobre suas ações, sobre seus conhecimentos e também sobre suas lacunas.

Os resultados nos levam a concluir a importância da vivência dos professores ainda em processo de formação inicial em dinâmicas como as desenvolvidas nesta investigação. Neste caminho percebemos que as atividades desenvolvidas pelos licenciandos possibilitaram com que estes refletissem sobre os problemas de sua 
atuação, estabelecendo um diálogo com a situação complexa, que envolve o processo de ensino-aprendizagem em sala de aula (JALBUT, 2011). Os licenciandos tiveram na sala de aula e na disciplina de Prática do Ensino de Química espaços de prática reflexiva que culminou na suscitação dos SADs.

Com o intuito de integrarmos os resultados obtidos fizemos um mapa conceitual (Figura 6) no qual buscamos relacionar os diferentes aspectos discutidos nesta investigação. Demos destaque para os processos ocorridos na disciplina de Prática do Ensino de Química vinculados ao Estágio Curricular Supervisionado, as quais colaboraram ao desenvolvimento e mobilização de saberes docentes. Saberes que possibilitaram a criação de ambientes argumentativos em sala de aula e de um olhar crítico dos licenciandos sobre sua prática docente. 


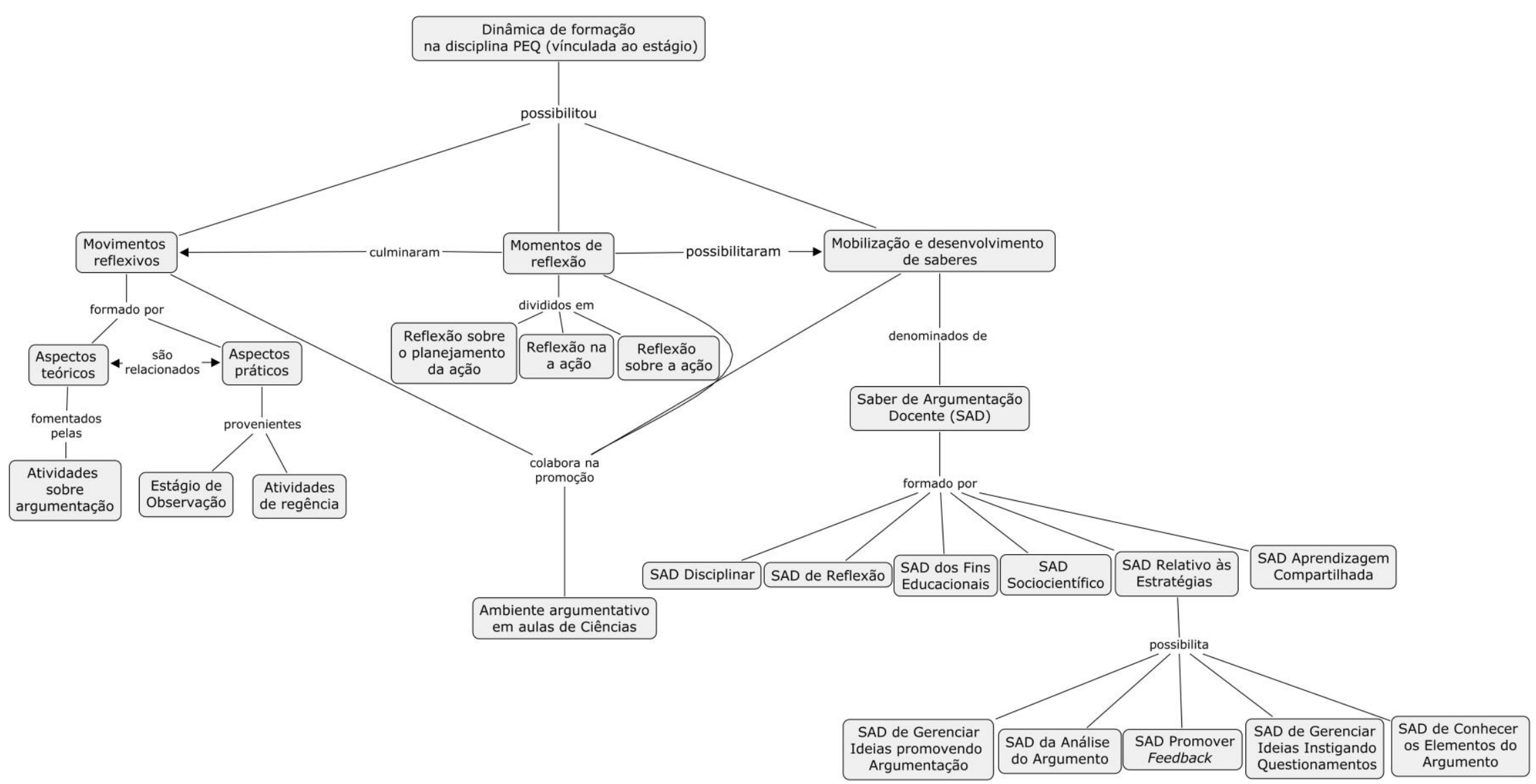

FIGURA 6: MAPA CONCEITUAL QUE BUSCA INTEGRAR OS RESULTADOS OBTIDOS AO LONGO DO PROCESSO DE INVESTIGAÇÃO REALIZADO NESTA PESQUISA 
Destacamos que no primeiro nível hierárquico do mapa encontra-se a Dinâmica de formação desenvolvida na disciplina de PEQ, que está vinculada diretamente as atividades de Estágio Curricular Supervisionado. Temos em seguida os Movimentos Reflexivos realizados pelos licenciandos, os seus Momentos de reflexão e a Mobilização e Desenvolvimento de Saberes.

A começar pelos Movimentos Reflexivos vimos que estes foram formados por um ciclo contínuo em que os alunos usaram de Aspectos Teóricos para analisarem suas ações Práticas e de outros Docentes, mas também usaram a Prática para pensarem de forma crítica na teoria, de maneira que pudessem contribuir com a formação teórica da área. Os conhecimentos sobre argumentação foram em sua maioria oriundos das atividades sobre argumentação realizadas pelos futuros professores e os aspectos práticos estavam vinculados as atividades de Estágio de Observação e do processo de elaboração, implementação e análise da regência em uma perspectiva argumentativa.

Estes Movimentos reflexivos possibilitaram os Momentos de Reflexão os quais dividimos em: Reflexão sobre o planejamento da ação, Reflexão na Ação e Reflexão Sobre a Ação, os quais compuseram o refletir dos licenciandos sobre todo o processo que compunham sua ação docente num buscar de desenvolver um ambiente em aulas de Química numa perspectiva argumentativa. Tais movimentos culminaram em uma mobilização e desenvolvimento de saberes docentes, os quais denominamos de Saber de Argumentação Docente e que a nosso ver formam a base de conhecimento ao docente para a promoção de atividades de natureza argumentativas.

Os saberes principais são vinculados ao conteúdo programático ao que o docente irá atuar, vinculando-o sempre que possível aos aspectos sóciocientíficos, ao saber da finalidade das atividades de natureza argumentativas, de um conhecer em desenvolver, implementar e usar as referidas atividades, de um processo de reflexão sobre todo o processo e de um processo de aprender de forma compartilhada. No que concerne ao saber das estratégias vemos que as mesmas são usadas de maneira a gerar novos saberes concernentes a gerenciar ideias para que os alunos justifiquem seus posicionamentos, que sejam atores questionadores do processo, e que os 
professores saibam sobre os elementos do argumento e que sempre forneçam um feedback aos alunos de suas ações. 


\section{CONSIDERAÇÕES FINAIS}

Nesta seção, sintetizamos os resultados e as discussões que nos deram embasamento ao estudo de como se configuram os momentos de reflexão de licenciandos em uma dinâmica de formação, vinculada ao Estágio Curricular Supervisionado, em que se priorizou o desenvolvimento de saberes de argumentação. Discutiremos também as limitações, contribuições e aplicações da investigação e propomos sugestões de estudos futuros que possam ampliar este trabalho de pesquisa. Ao final, apresentaremos as conclusões em estreita associação com as questões de pesquisa.

\subsection{Síntese dos Resultados}

Em relação às concepções iniciais dos licenciandos sobre argumentação constatamos que estes as consideram como um processo em que os sujeitos necessitam apresentar seus posicionamentos, contrastá-los e justificá-los mediante determinado público. Alguns relatam a necessidade de considerar as justificativas para apoiar as informações, os conhecimentos e as bases confiáveis para defendê-las. Consideram ainda que a argumentação ocorre tanto num movimento em que alunos argumentam para seus professores quanto no sentido contrário. Também se posicionam favoráveis ao uso de estratégias que potencializam um ambiente argumentativo em sala de aula. Notamos ao longo das atividades o aumento considerável do conhecimento dos licenciandos sobre aspectos da argumentação e de estratégias de ensino que podem favorecer ações educativas numa perspectiva argumentativa. 
Ao longo do estágio de observação os futuros docentes foram vivenciando novas experiências, participando das ações desenvolvidas pela professora da escola básica e tomando ciência e contato com o ambiente escolar, sob uma perspectiva docente. Também relataram suas experiências e, principalmente, expressaram seus sentimentos e reflexões sobre como determinadas ações poderiam ser modificadas visando um processo de ensino-aprendizagem mais eficaz. Já num contexto em que trabalhamos as teorias da argumentação, com o intuito de formar e/ou aprimorar uma base conceitual sobre a temática, tivemos a possibilidade de discutir aspectos sobre a argumentação, as estratégias de ensino e as necessidades do professor para criar um ambiente argumentativo.

Na etapa de regência, em que os licenciandos planejaram, implementaram e analisaram ações docentes numa perspectiva de promover a argumentação em sala de aula, identificamos a ocorrência de movimentos reflexivos compostos pela Reflexão no Planejamento da Ação, Reflexão na Ação e Reflexão sobre a Ação. Estes movimentos possibilitaram que os licenciandos desenvolvessem e/ou aprimorassem saberes docentes concernentes à promoção da argumentação em sala de aula.

Analisando os dados construídos a partir das falas dos licenciandos, juntamente com aspectos teóricos da argumentação, pudemos identificar seis saberes principais, que em nossa concepção colaboram para a emergência da argumentação em contexto de sala de aula. Os saberes foram denominados de saberes de Argumentação Docente (SAD), que podem ser caracterizados por: SAD Relativo às Estratégias, SAD de Reflexão, SAD dos Fins Educacionais, SAD Sociocientífico, SAD de Reflexão, SAD Disciplinar e SAD da Aprendizagem Compartilhada. Além destes, definimos como subcategorias do SAD Relativo às Estratégias os: SAD de Gerenciar Ideias promovendo Justificação, SAD Promover Feedback, SAD de Conhecer os Elementos do Argumento, SAD de Gerenciar ideias Instigando Questionamentos e o SAD da Análise do Argumento.

\subsection{Síntese da Discussão}

Os licenciandos, ao longo das atividades desenvolvidas na dinâmica de formação, foram modificando e ampliando suas concepções iniciais sobre a argumentação, mudanças estas facilitadas pelo modelo de formação adotado, que 
teve como base a Racionalidade Prática. Ao realizarem a regência, os licenciandos participaram de um movimento cíclico em que utilizaram as teorias que concernem à argumentação e a prática em sala de aula, para desenvolverem aulas numa perspectiva argumentativa. Tal movimento possibilitou que os mesmos baseassem sua prática em um arcabouço conceitual e pudessem entender seus resultados a partir de uma perspectiva teórica e prática, em que assumiram sua regência como um espaço de reflexão sobre a prática docente.

Ao longo do processo de formação, ficou evidente a contribuição significativa das ações coletivas em que os licenciandos puderam ter momentos de troca de experiências com seus pares, profissionais mais experientes e com pesquisadores da universidade. Esta combinação contribuiu para uma ação mais consciente e reflexiva sobre a prática docente dos licenciandos. Pudemos, por meio do movimento cíclico e das reflexões dos futuros professores, identificar elementos preconizados por Schön (2000), os quais integram o desenvolvimento de uma prática na formação de um profissional reflexivo, sendo a Reflexão na Ação e a Reflexão sobre a ação.

Ampliamos tais interpretações sobre os momentos de reflexão, ao considerar que ocorreu uma Reflexão no Planejamento da Ação, em que o licenciando refletiu de forma individual e coletiva sobre as atividades que precediam suas ações em sala de aula. Acrescentamos que este elemento perpassou todo o desenvolvimento da regência, pois constantemente os licenciandos analisavam como desenvolver suas aulas, que características utilizar no desenvolvimento das estratégias, como se colocarem como docentes, entre outros aspectos. A Reflexão no Planejamento da Ação possibilitou que tivessem uma visão mais focada para uma análise de sua ação (Reflexão na Ação) no momento de sala de aula e após a mesma (Reflexão sobre a Ação).

Consideramos que a Reflexão sobre a Ação ocorreu em momentos que os licenciandos se afastaram da regência e podiam refletir a partir de uma visão teóricaprática e de forma individual e compartilhada sobre suas ações em sala de aula. Este momento foi fundamental, já que possibilitou aos licenciandos terem um entendimento de suas práticas pedagógicas, em que puderam reavaliar suas ações desde o sucesso aos pontos deficientes, em um movimento de resignificação e 
replanejamento de suas ações. Este momento foi caracterizado como um retomar das ações, em que procuramos relacionar a questão prática à teórica. Consideramos que a iniciativa de gravar as regências em vídeo e depois disponibilizar aos alunos, caracterizou-se como material importante para a condução da dinâmica e qualidade das discussões das reflexões sobre a ação.

Os movimentos e momentos de reflexão possibilitaram aos licenciandos mobilizarem e desenvolverem Saberes de Argumentação Docente, que definimos e identificamos com base no trabalho de Tardif (2010) e nas ideias de Freire (1996), principalmente por considerarmos que é necessário dar aos licenciandos a possibilidade de se assumirem como sujeitos da produção do saber e que ensinar não é transferir conhecimento, mas criar possibilidades para sua elaboração. Além disso, trabalhos como de Jimenez-Aleixandre (2005), Dawson, Venville, (2010) e Evagorou e Osborne (2013) nos deram a base para analisarmos os saberes desde uma perspectiva argumentativa.

Ao longo de todas as atividades desenvolvidas os licenciandos mostram-se receptivos ao compartilhamento de suas experiências e das considerações realizadas por seus colegas e responsáveis pela disciplina. Foi constante a colocação de que se sentiam à vontade para falar das suas dificuldades, êxitos e fracassos ao longo do percurso de regência, o que em muitos momentos, significou ter no colega uma fonte de colaboração, vindo a reforçar os aspectos da racionalidade prática. Tal resultado vem ao encontro das colocações de pesquisadores como Schön (2000), Garrido e Carvalho (1999), Sannamed e Abeledo (2010) e Jalbut (2011), que apoiam a necessidade do professor organizar sua prática com base em reflexões ocorridas em diferentes momentos da ação docente.

\subsection{Limitações da Investigação}

Compreendemos as limitações inerentes a uma pesquisa do tipo estudo de caso. No entanto, estudos desta natureza possibilitam uma interpretação dos fenômenos no seu contexto natural, realizada de forma profunda e que pode possibilitar ao leitor estabelecer relações e se apropriar do que for compatível a sua realidade. 
Ao longo da pesquisa identificamos onze Saberes de Argumentação Docente, os quais facilitaram o desenvolvimento das atividades dos licenciandos que visavam à promoção de um ambiente argumentativo em aulas de Ciências. Acreditamos que existem mais saberes que dão sustentação ao desenvolvimento de habilidades argumentativas e que as relações entre os saberes possam ser mais exploradas.

\subsection{Aplicação e contribuições da Investigação}

Consideramos que as atividades desenvolvidas nesta pesquisa podem contribuir para compor um conjunto de referências para a organização de momentos de formação inicial de professores no que tange à argumentação. Nosso estudo identificou evidências sobre a importância de incorporar a argumentação em disciplinas vinculadas ao Estágio Curricular Supervisionado de futuros professores de Ciências. Evidenciamos a importância de trabalhar com um modelo de formação pautado na Racionalidade Prática e obtivemos que é possível desenvolver atividades nos cursos de formação inicial em que haja momentos de reflexão dos licenciandos em um âmbito individual e coletivo.

Em especial, destacamos três momentos de reflexão (Reflexão no Planejamento da Ação, Reflexão na Ação e Reflexão sobre a Ação), os quais, juntamente com a teoria sobre argumentação e a prática dos licenciandos, podem possibilitar aos futuros professores experimentarem, estudarem e proporem soluções para o trabalho da argumentação em sala de aula e desenvolverem e mobilizarem saberes. Além disso, os SADs podem servir de base para o estudo dos saberes necessários ao professor para desenvolver atividades de natureza argumentativa e também ao formador de professores para que possa planejar atividades em que o desenvolvimento destes saberes sejam facilitados.

O modelo de formação vinculado ao estágio desenvolvido nesta tese poderá servir como uma alternativa à organização de cursos de formação de professores que visem trabalhar habilidades argumentativas docentes, desde uma imersão em situação real de sala de aula e do trabalho em equipe. Acreditamos que o desenvolvimento efetivo de tais habilidades é concretizado quando o licenciando vivência a necessidade deste conhecimento em sua formação e em sua prática docente. 


\subsection{Conclusões}

No intuito de gerar conhecimentos para os cursos de formação inicial de professores da área de Ciências Exatas no que concerne ao desenvolvimento de saberes da argumentação docente, nos pautamos em duas questões de investigação, a saber: Como se configuram os momentos de reflexão explicitados por futuros professores de Ciências em uma dinâmica de formação vinculada a atividades de Estágio Curricular Supervisionado, que priorizam o desenvolvimento de saberes de argumentação? E Quais saberes futuros professores de Ciências desenvolvem no sentido de promover um ensino de caráter argumentativo?

Obtivemos que os momentos de reflexão, vivenciados pelos licenciandos no âmbito das ações ocorridas em uma perspectiva teórica e prática, culminaram nos movimentos de Reflexão sobre o planejamento da ação, Reflexão na ação e Reflexão sobre a ação. Além disso, destacamos que os momentos de reflexão vinculados ao estágio e às discussões ocorridas nos diferentes momentos da dinâmica de formação apresentaram-se fundamentais para a superação de um modelo de formação pautado na Racionalidade Técnica para a formação em que a base foi a Racionalidade Prática.

Identificamos que a referida dinâmica possibilitou um movimento em que os aspectos teóricos e práticos estavam em um constante movimento articulado, no sentido da prática sendo utilizada para dar sentido à teoria e vice-versa. Este movimento colaborou para que os futuros professores tivessem uma vivência em considerar a sua prática docente como um ambiente de estudo, de maneira a buscar sempre melhorá-la e se desenvolver profissionalmente.

Percebemos que as atividades sobre argumentação foram fatores primordiais para o desenvolvimento da base teórica dos licenciandos sobre a temática. Entendemos também que as ações relacionadas ao Estágio de Observação e a Atividade de regência possibilitaram este movimento recíproco de Teoria-Prática. Além disso, o fato dos licenciandos terem compartilhado seus planejamentos e reflexões com os demais colegas e responsáveis pela disciplina possibilitou encontrarem sustentação e crescimento mútuo numa busca de uma prática social.

Atrelando aos movimentos reflexivos nos diferentes momentos de reflexão, percebemos o surgimento de saberes relacionados com a argumentação em sala de 
aula, que denominamos de Saberes de Argumentação Docente. Estes saberes foram divididos em seis grandes categorias e tiveram como base dois conjuntos de aspectos: o primeiro, em que nos baseamos em referenciais teóricos relacionados aos saberes docentes dos professores (TARDIF, 2010 e FREIRE, 1996) e em referências como Sasseron e Carvalho (2011a), Jiménez-Aleixandre (2010) e Toulmin (2001), que abordam o processo argumentativo em sala de aula. $\mathrm{O}$ segundo conjunto de elementos, foi baseado na própria prática dos licenciandos. Desta maneira, buscamos atrelar teoria e elementos provenientes dos dados para a elaboração das categorias.

Com base em nossos resultados, assumimos o momento do Estágio Curricular Supervisionado como um espaço fundamental para o desenvolvimento e mobilização de saberes docentes no sentido de que os licenciandos, ao se formarem, possam ter habilidades que possibilitem o desenvolvimento de aulas de ciências numa perspectiva argumentativa.

Concluímos que o uso do modelo da Racionalidade Prática possibilitou que os licenciandos refletissem sobre sua prática docente na perspectiva da criação de ambiente argumentativo em suas regências, desde uma percepção individual como coletiva. Vimos que o referido modelo, ao servir de base para o desenvolvimento de atividades vinculadas ao Estágio Curricular Supervisionado com foco na argumentação, possibilitou a valorização do trabalho e da aprendizagem com os pares com relação à elaboração de Saberes de Argumentação Docente.

Assim, destacamos que consideramos a argumentação como uma ferramenta valiosa no processo de ensino-aprendizagem da área de ensino de ciências e na formação de um cidadão com um maior compromisso social. Neste sentido, enfatizamos a importância de que os futuros professores desde sua formação inicial reconheçam a importância da argumentação e tenham a oportunidade de planejarem, implementarem e avaliarem atividades desta natureza.

\subsection{Futuras Investigações}

A partir do estudo realizado, destacamos a necessidade de aprofundarmos a questão de como os licenciandos se apropriam dos conhecimentos teóricos abordados 
nas disciplinas vinculadas ao Estágio Curricular Supervisionado para desenvolverem saberes que visem à promoção da argumentação em sala de aula.

Este estudo traz uma importante contribuição para o desenvolvimento de novas estratégias e/ou aprimoramento das existentes, como as utilizadas neste trabalho, visando o desenvolvimento de SAD ainda no contexto de formação inicial. Consideramos que é possível aprofundar o estudo sobre como ocorre à influência entre diferentes saberes. Assim, julgamos importante pesquisar como os SADs colaboram para o desenvolvimento de outros saberes docente, que também podem contribuir à melhoria da prática docente no Ensino de Ciências. 


\section{REFERÊNCIAS}

ABIB, M. L. V. S. Em busca de uma nova formação de professores. Pesquisas em Ensino de Ciências e Matemática. Bauru: Faculdade de Ciências, UNESP, Série Educação para a Ciência, n. 3, p. 60-72; 1996.

ACAR, L. T. O.; ROYCHOUDHURY, A. Student difficulties in socio-scientific argumentation and decision making research findings: crossing the borders of two research lines. International Journal of Science Education. v. 32(9), p. 1191-1206, 2010.

ALMEIDA, P. C. A.; BIAJONE, J. Saberes docentes e formação inicial de professores: implicações e desafios para as propostas de formação. Educação e Pesquisa, v. 33(2), p. 281-295, 2007.

ANDRE, M. E. D.A. Estudo de caso: seu potencial na educação. Caderno de Pesquisa, v 49, p. 51-54, 1984.

ARAUJO, M. P. Formação docente: caminhos percorridos em busca de um processo Colaborativo Disponível em: HTTP://www.ufpi.br/subsiteFiles/ppged/arquivos/files/evevtos2009/GT.2/36 Marlinda\%20Pessoa\%20Araujo.pdf, 2009.

ARCHILA, P. A. La investigación en argumentación y sus implicaciones en la formación inicial de profesores de ciências. Revista Eureka sobre Enseñanza y Divulgación de las Ciencias, v. 9(3), p. 361-375, 2012.

ARRUDA, S. M.; LIMA, J. P. C.; MENEGHELLO, M. Um novo instrumento para a análise da ação do professor em sala de aula. Revista Brasileira de Pesquisa em Educação em Ciências v. 11(2), p. 139-160, 2011 
ASSIS, A.; TEIXEIRA, O. P. B. Argumentações discentes e docente envolvendo aspectos ambientais em sala de aula: uma análise. Ciência \& Educação, v. 15(1), p. 47-60, 2009.

AUFSCHNAITER, C. V.; ERDURAN, S.; OSBORNE J.; SIMON, S. Arguing to learn and learning to argue: Case studies of how students' argumentation relates to their scientific knowledge. Journal of Research in Science Teaching, v.45(1), p. 101-131, 2008.

AZEVEDO, M. N. Pesquisa-ação e atividades investigativas na docência em ciências. 2008. 224 f. Dissertação (Mestrado em Pós-graduação em Educação) - Faculdade de Educação da Universidade de São Paulo, 2008.

AZEVEDO. M. A. R. Os saberes de orientação dos professores formadores: desafios para ações tutoriais emancipatórias. 2009. 259 f. Tese (Doutorado em Pós-Graduação em Educação) - Faculdade de Educação da Universidade de São Paulo, 2009.

BACCON, A. L. P.; ARRUDA, S. M. Os saberes docentes na formação inicial do professor de física: elaborando sentidos para o estágio supervisionado. Ciência \& Educação, v. 16(3), p. 507-524, 2010.

BARGALLÓ, C. M.; PRAT, A. Favorecer la argumentación a partir de la lectura de textos. Alambique. Didáctica de las Ciencias Experimentales, n. 63, p 39-49, 2010.

BARREIRO, I. M. F.; GEBRAN, R, A. (orgs.). Prática de ensino e estágio supervisionado na formação de professores. São Paulo: Avercamp, 2006.

BATISTA, E. R. M.; MORAES, A:A:A. As concepções de formação: aproximações teóricas. Revista EDUCAmazônia Educação Sociedade e Meio Ambiente, 2009.

BELEI, R. A.; GIMENIZ-PASCHOAL, S. R.; NASCIMENTO, E. N.; MATSUMOTO, P. H. V. R. O uso de entrevista, observação e videogravação em pesquisa qualitativa. Cadernos de Educação FaE/PPGE/UFPel, Pelotas v. 30, p 187 - 199, janeiro/junho 2008

BIANCHI, A. C. M.; ALVARENGA, M.; BIANCHI, R. Orientação para estágio em licenciatura. São Paulo: Thomson Learning, 2005.

BONI, V.; QUARESMA, S. J. Aprendendo a entrevistar: como fazer entrevistas em Ciências Sociais. Revista Eletrônica dos Pós-Graduandos em Sociologia Política da UFSC, v. 2, 1(3), p. 68-80, 2005.

BRASIL. Diretrizes e Bases da Educação Nacional. Lei $n^{\circ}$ 9.394/1996, de 20 de dezembro de 1996. Estabelece as diretrizes e bases da educação nacional. Diário Oficial da União. Brasília, DF, 23 dez. 1996. Disponível em: http://bd.camara.gov.br/bd/bitstream/handle/bdcamara/2762/ldb_5ed.pdf. 
BRASIL. Parâmetros Curriculares Nacionais Ensino Médio. Disponível em: <http://portal.mec.gov.br/seb/arquivos/pdf/blegais.pdf>, 2000. Acesso em: 15 de fevereiro de 2010.

BRASIL. Ministério da Educação. CONSELHO NACIONAL DE EDUCAÇÃO CONSELHO PLENO RESOLUÇÃO CNE/CP 1, DE 18 DE FEVEREIRO DE 2002. Institui Diretrizes Curriculares Nacionais para a Formação de Professores da Educação Básica, em nível superior, curso de licenciatura, de graduação plena. Disponível em: http://portal.mec.gov.br/cne/arquivos/pdf/CP012002.pdf.

BRASIL. Ministério da Educação. CONSELHO NACIONAL DE EDUCAÇÃO. Parecer CNE/CP 28/2001: Dá nova redação ao Parecer CNE/CP 21/2001, que estabelece a duração e a carga horária dos cursos de Formação de Professores da Educação Básica, em nível superior, curso de licenciatura, de graduação plena. Disponível em: http://portal.mec.gov.br/cne/arquivos/pdf/028.pdf.

BRAVO, B.; JIMÈNEZ-ALEIXANDRE, M. P. ¿Salmones o sardinas? Una unidad para favorecer el uso de pruebas y la argumentación en ecología. Alambique. Didáctica de las Ciencias Experimentales, n. 63, p. 19-25, 2010.

BROIETTI, F. C. D.; BARRETO, S. R. G. Formação inicial de professores de química: a utilização dos relatórios de observação de aulas como instrumentos de pesquisa. Semina: Ciências Exatas e Tecnológicas, Londrina, v. 32(2), p. 181-190, 2011.

BROWN, R. Exploring the social positions that students construct within a classroom community of practice. International Journal of Educational Research. v 46, p. 116-128, 2007.

CAAMAÑO, A. Argumentar em ciencias. Alambique. Didáctica de las Ciencias Experimentales, n. 63, p. 5-10, 2010.

CAPECCHI, M. C. V.; CARVALHO, A. M. P.; SILVA, D. Relações entre o discurso do professor e a argumentação dos alunos em uma aula de física. Ensaio. Pesquisa em Educação em Ciências, Belo Horizonte, v. 2(2), p. 189208, 2002.

CAMPOS, L. M. L.; DINIZ, R. E. S. A prática como fonte de aprendizagem e o saber da experiência: o que dizem professores de Ciências e de biologia. Investigações em Ensino de Ciências. v. 6(1), p. 79-96, 2001.

CAPECCHI, M. C. V. M.; CARVALHO, A. M. P. Argumentação em uma aula de conhecimento físico com crianças na faixa de oito a dez anos. Investigações em Ensino de Ciências, v. 5(3), p. 171-189, 2000.

CAPECCHI, M. C. V.; CARVALHO, A. M. P.; SILVA, D. Relações entre o discurso do professor e a argumentação dos alunos em uma aula de física. 
Ensaio - Pesquisa em Educação em Ciências, Belo Horizonte, v. 2(2), p. 189208, 2002.

CARVALHO, A. M. P. Os Estágios nos cursos de Licenciatura. São Paulo: Cengage Learning. 2012.

CARVAlho, A. M. P. Práticas Experimentais no Ensino de Física, In: CARVALHO, A.M.P., Ensino de Física. $1^{a}$ ed., p. 53-78, São Paulo: Cengage Learning, 2010.

CARVAlHO, A. M. P. Prática de Ensino. Os estágios na formação do professor. São Paulo: Livraria Pioneira, 1985.

CHAMIZO, J. A. G. Las aportaciones de Toulmin a la enseñanza de las ciencias. Enseñanza de las Ciencias, v. 25(1), p. 133-146, 2007.

CHIARO, S.; LEITÃO, S. O papel do professor na construção discursiva da argumentação em sala de aula. Psicologia: Reflexão e Crítica, v. 18(30), p. 350-357, 2005.

COLOMBO JR., P. C.; LOURENÇO, A. B.; SASSERON, L. H; CARVALHO, A. M. P. Ensino de física nos anos iniciais: análise da argumentação na resolução de uma atividade de conhecimento físico. Investigações em Ensino de Ciências (Online), v. 17, p. 489-507, 2012.

CONSELHO NACIONAL DE EDUCAÇÃO. Parecer CNE/CP 28/2001: Dá nova redação ao Parecer CNE/CP 21/2001, que estabelece a duração e a carga horária dos cursos de Formação de Professores da Educação Básica, em nível superior, curso de licenciatura, de graduação plena. Disponível em: http://portal.mec.gov.br/cne/arquivos/pdf/028.pdf.

COSTA, A. Desenvolver a capacidade de argumentação dos estudantes: um objetivo pedagógico fundamental. Revista Iberoamericana de Educación, n. 46/5, p. 18, 2008.

COUTINHO C. P.; CHAVES, J. H. O estudo de caso na investigação em Tecnologia Educativa em Portugal. Revistas Portuguesa de Educação, v. 15(1), p. 221243, 2002.

CROSS, D.; TAASOOBSHIRAZI, G.; HENDRICKSC, S.; HICKEYA, D. T. Argumentation: A strategy for improving achievement and revealing scientific identities. International Journal of Science Education, v.30, p. 837-861, 2008.

DAWSON, V.; VENVILLE, G. J. High-school students' informal reasoning and argumentation about biotechnology: An indicator of scientific literacy? International Journal of Science Education, v. 31(11), p. 1421-1445, 2009. 
ERDURAN, S.; SIMON, S.; OSBORNE, J. Tapping into argumentation: developments in the application of Toulmin's argument pattern for studying science discourse. Science Education, v. 88(6), p. 915-933, 2004.

EVAGOROU, M.; OSBORNE, J. Exploring Young Students' Collaborative Argumentation Within a Socioscientific Issue. Journal of Research in Science Teaching, v. 50(2), p. 209-237, 2013.

FERNANDES, D.; FONSECA, L. Argumentação e Demonstração no Contexto da Formação Inicial de Professores. Disponível em: http://spiem.pt/DOCS/ATAS_ENCONTROS/2003/2003_13_DFernandes.pdf.

Acesso em: 12 de fevereiro de 2013.

FREIRE, Paulo. Pedagogia da autonomia. Saberes necessários à prática educativa. $7^{\mathrm{a}}$ ed. São Paulo: Paz e Terra, 1996.

FREITAS, D.; VILLANI, A. Formação de professores de ciências: um desafio sem limites. Investigações em Ensino de Ciências, v.7(3), p. 215-230, 2002.

GALINDO, M. A. O. Melhoria do ensino de ciências nas séries iniciais do ensino fundamental: contribuições e limites de um projeto colaborativo. 2007. Dissertação (Mestrado em Pós-Graduação Interunidades em Ensino de Ciências) - Universidade de São Paulo, Secretaria da Educação do Estado de São Paulo.

GALINDO; M: A. O professor da escola básica e o estágio supervisionado: sentidos atribuídos e a formação inicial docente. 2012. 296 f. Tese (Doutorado em PósGraduação em Educação da USP) - Faculdade de Educação, 2012.

GARCÉS, A. M. G; PRIETO, M. S. F. Análisis crítico del prácticum de magisterio en una facultad de formación de profesorado y educación. Tendencias Pedagógicas. n.14, p. 417-432, 2009.

GARCÍA DE CAJÉN, S.; DOMÍNGUEZ CASTIÑEIRAS, J. M.; GARCÍARODEJA F. E. Razonamiento y argumentación en ciencias. diferentes puntos de vista en el currículo oficial. Enseñanza de las Ciencias, v.20(2), p. 217-228, 2002.

GARCÍA, C. M. Pesquisa sobre formação de professores: o conhecimento sobre aprender a ensinar. Revista Brasileira de Educação, n. 9, p. 51-75, 1998.

GARCIA, L.; VALEIRAS, N. Lectura y escritura en el aula de ciencias: una propuesta para reflexionar sobre la argumentación. Didáctica de las Ciencias Experimentales, n. 63, p. 57-64, 2010.

GARRIDO, E.; CARVALHO, A. M. P. Reflexão sobre a prática e qualificação da formação inicial docente. Cadernos de Pesquisa, n.107, p.149-168, julho, 1999. 
GARRIDO, E.; Desafios à pesquisa que o professo faz sobre sua prática. In: PENTEADO, H. D.; GARRIDO, E. (orgs.) Pesquisa-ensino: a comunicação escolar na formação do professor. São Paulo: Paulinas, 2010.

GAUTHIER, C.; MARTINEAU, S.; DESBIENS, J.; MALO, A.; SIMARD, D. Por uma teoria da pedagogia - pesquisas contemporâneas sobre o saber docente. Rio Grande do Sul: Editora UNIJUÍ, 1998.

GHEDIN, E. L. Professor-reflexivo: da alienação da técnica à autonomia da crítica. Disponível em: <http://www.anped.org.br/reunioes/29ra/trabalhos/trabalho/GT08-2403-Int.pdf>, Acesso em: 08 de janeiro de 2012. 2001.

GUTIÉRREZ R. M. F., CORREA, R. M. Argumentación y concepciones implícitas sobre física: un análisis pragmadialéctico. Acta Colombiana de Psicología, v.11 (1), p. 55-63, 2008.

HENAO, B. L.; STIPCICH, M. S. Educación en ciencias y argumentación: la perspectiva de Toulmin como posible respuesta a las demandas y desafíos contemporáneos para la enseñanza de las ciencias experimentales. Revista Electrónica de Enseñanza de las Ciencias, v. 7(1), p. 47-62, 2008.

ISLAS. S. M.; SGRO, M. R.; PESA, M. A. La argumentación en la comunidad científica y en la formación de profesores de física. Ciência e Educação, v.15(2), p. 291-304, 2009.

JALBUT, M. V. Fundamentos teóricos para a formação de professores: a prática reflexiva, Veras Revista Acadêmica de Educação do ISE Vera Cruz, v.1(1), p. 66-85, 2011.

JIMÉNEZ-ALEIXANDRE, M. P. 10 ideas clave - competencias en argumentación y uso de pruebas. Barcelona: Graó, 2010.

JIMÉNEZ-ALEIXANDRE, M. P. A argumentação sobre questões sócio-científicas: processos de construção e justificação do conhecimento na aula. Atas do V Encontro Nacional de Pesquisa em Ensino de Ciências, 2005.

JIMÉNEZ-ALEIXANDRE, M. P.; BUSTAMANTE, J. D. Discurso de aula y argumentación em la clase de ciencias: cuestiones teóricas y metodológicas. Enseñanza de las Ciencias, v. 21(3), p. 359-370, 2003.

JIMÉNEZ-ALEIXANDRE, M. P.; CASTRO, C. R.; PÉREZ, V. A. Argumentación en el laboratorio de física. In: ENCONTRO DE PESQUISA EM ENSINO DE FÍSICA, Florianópolis. Resumos. Florianópolis: Sociedade Brasileira de Física, 1998.

JIMÉNEZ-ALEIXANDRE, M. P.; RODRÍGUEZ, A. B. "Doing the Lesson" or "Doing Science": Argument in High School Genetics. Science Education, v. 84(6), p. 757-792, 2000. 
JIMÉNEZ-ALEIXANDRE, M., P.; OTERO, J. R. G.; SANTAMARÍA, F. E.; MAURIZ, B. P. Actividades para trabajar el uso de pruebas y la argumentación en ciencias. Editora: Santiago de Compustela, 2009.

JORDÃO, R. S. Tutoria e Pesquisa-ação no Estágio Supervisionado: Contribuições para a Formação de Professores de Biologia. 2005.120 f. Tese (Doutorado em Pós-Graduação em Educação) - Faculdade de Educação da Universidade de São Paulo, 2005.

KENSKI, V. M. A vivência escolar dos estagiários e a prática de pesquisa em estágios supervisionados. In.: PICONEZ, S. (Coord.) - A prática de ensino e o estágio supervisionado. Campinas: Papirus, 1991.

LABURÚ, C. E.; BARROS, M. A.; KANBACH, B. G. A relação com o saber profissional do professor de física e o fracasso da implementação de atividades experimentais no ensino médio. Investigações em Ensino de Ciências, v. 12(3), p.305-320, 2007.

LANGHI, R,; NARDI, R. Formação de professores e seus saberes disciplinares em astronomia essencial nos anos iniciais do ensino fundamental. Rev. Ensaio Belo Horizonte, v.12(02) p.205-224, mai-ago, 2010.

LARRAÍN, A. J. C. Donald Schön: una práctica profesional reflexiva en la universidad. COMPÁS Empresarial, v. 3(5), p. 54-58, 2011.

LEMKE, J. L., Investigar para el Futuro de la Educación Científica: Nuevas Formas de Aprender, Nuevas Formas de Vivir. Enseñanza de las Ciencias, v.24(1), p.5-12, 2006.

LONGUINI, M. D.; NARDI, R. Uma pesquisa sobre a prática reflexiva na formação inicial de professores de física. ENSAIO - Pesquisa em Educação em Ciências. v.4 (2), p. 1-13, 2002.

MALDANER, O. A. A formação inicial e continuada de professores de química. Ijuí: UNIJUİ, 2000.

MEC, Ministério da Educação. Disponível em: http://portal.inep.gov.br. Acesso em: 11 de maio de 2012.

MELLADO JIMENEZ, V. Concepciones y prácticas de aula de profesores de ciências, em formacion inicial de primaria y secundaria. Enseñanza de Las Ciencias, v. 14, n. 3, p. 289-302, 1996.

MELO, G. F. Estágio na formação inicial de professores: aguçando o olhar, desenvolvendo a escuta sensível. In: SILVA, L. C. (org). Estágio Supervisionado e prática de ensino: desafios e possibilidades. Araraquara: Junqueira \&Marin, 2008. 
MIZUKAMI, M. G. N.; REALI, A. M. M. R.; REYES, C. R.; MARTUCCI, E. M.; LIMA, E. R.; TANCREDI, R. M. S. P.; MELLO, R. R. Escola e aprendizagem da docência: processos de investigação e formação. São Carlos: EdUFSCar, 2002.

MONTEIRO, A. M. A prática de ensino e a produção de saberes na escola. In: CANDAU, V. M. (org.) Didática, Currículo e saberes escolares. Rio de Janeiro: DP\&A, 2002.

MONTEIRO, M. A. A.; TEIXEIRA, O. P. B. Uma análise das interações dialógicas em aulas de ciências nas séries iniciais do ensino fundamental. Investigações em Ensino de Ciências, v. 9 (3), p. 243-263, 2004.

MORAES, R. Análise de conteúdo. Revista Educação. Porto Alegre, v. 22(37), p. 732, 1999.

MORAES; V. R. A. Estágio e supervisão ecológica: crenças e saberes na aprendizagem da docência. 2010. 314.f. Tese (Doutorado em Pós Graduação FEUSP) - Faculdade de Educação da Universidade de São Paulo, 2010.

NASCIMENTO, S. S.; PLANTIN, C.; VIEIRA, R. D. A validação de argumentos em sala de aula: um exemplo a partir da formação inicial de professores de física. Investigações em Ensino de Ciências, v.13(2), p.169-185, 2008.

NASCIMENTO, S. S.; VIEIRA, R. D. Contribuições e limites do padrão de argumento de Toulmin aplicado em situações argumentativas de sala de aula de Ciências. Revista Brasileira de Pesquisa em Educação em Ciências, v.8(2), p. 1-20, 2008.

NUNES, C. M. F. Saberes docentes e formação de professores: um breve panorama da pesquisa brasileira. Educação \& Sociedade, ano XXII, n ${ }^{\circ} 74$, p. 27-42, Abril/2001.

OFICIAL DA UNIÃO. Parecer nº: CNE/CP 28/2001. Dá nova redação ao Parecer CNE/CP 21/2001, que estabelece a duração e a carga horária dos cursos de Formação de Professores da Educação Básica, em nível superior, curso de licenciatura, de graduação plena. Disponível em: http://portal.mec.gov.br/cne/arquivos/pdf/028.pdf, 2001b.

OFICIAL DA UNIÃO. Parecer n $\mathrm{n}^{\mathbf{0}}$ :CNE/CP 009/2001: Diretrizes Curriculares Nacionais para a Formação de Professores da Educação Básica, em nível superior, curso de licenciatura, de graduação plena: Despacho do Ministro em 17/1/2002, publicado no Diário Oficial da União de 18/1/2002, Seção 1, p. 31. Disponível em: < http://portal.mec.gov.br/cne/arquivos/pdf/009.pdf>, 2001 a.

OFICIAL DA UNIÃO. Resolução CNE/CP 01, de 18 de Fevereiro de 2002 - Institui Diretrizes Curriculares Nacionais para a Formação de Professores da Educação Básica, em nível superior, curso de licenciatura, de graduação plena. Diário 
Oficial da União, Brasília, 09 Abr. 2002, Seção 1, p. 31, 2002 Disponível em: http://portal.mec.gov.br/cne/arquivos/pdf/rcp01_02.pdf, 2002.

PADILHA, J. N., CARVALHO, A. M. P. Relações entre os gestos e as palavras utilizadas durante a argumentação dos alunos em uma aula de conhecimento físico. Revista Brasileira de Pesquisa em Educação em Ciências, v.11(2) 2, p. 25-40, 2011.

PATRONIS, T.; POTARI, D.; SPILIOTOPOULOU, V. Students' argumentation in decision-making on a socio-scientific issue: implications for teaching. International Journal of Science Education, v. 21(7), p. 745-754, 1999.

PENTEADO, H. D. Pesquisa-ensino e formação de professores. In: PENTEADO, H. D.; GARRIDO, E. (orgs.) Pesquisa-ensino: a comunicação escolar na formação do professor. São Paulo: Paulinas, 2010.

PEREZ, D. M.; REBECHI, D.;AZEVEDO, K. L.; SCHREINER, P. G.; MATTIA, R. C.; SLOWIK, R.; OLIVEIRA, O. B. Temas polêmicos e a argumentação de estudantes do curso de ciências biológicas. Rev. Ensaio Belo Horizonte, v.13(02) p.135-150 mai-ago 2011.

PINTO, M. G. G.; FELDKERCHER, N.; VASCONCELOS, C. O estágio curricular supervisionado nos cursos de formação de professores da UFPel: Limites, Dilemas, Perspectivas, In: GAIGER, P. J. G.; PINTO, M.G.G.; PITANO, S.C. (orgs). Currículo e projeto pedagógico, estágio e formação continuada: outros olhares e outras reflexões. Pelotas: Ed. da UFPEL, 2010.

RAMOS, E. E.; RUZ, T. P. Problemas socio-científicos y enseñanza-aprendizaje de las ciências. Investigación en la escuela, p. 17-24, 2010.

REBECHI, D.; AZEVEDO K. L.; SCHREINER, P. G.; MATTIA, R. C.; SLOWIK, R.; OLIVEIRA, O. B. Temas polêmicos e a argumentação de estudantes do curso de ciências biológicas. Rev. Ensaio Belo Horizonte, v.13(02), p.135-150, mai-ago 2011.

RODRIGUES, M. I. R. Aspectos do Desenvolvimento Profissional dos Formadores de Professores de Ciências: no contexto de integração - Universidade, Diretorias Regionais de Ensino e Escolas. 2006. 248 f. Tese (Doutorado em Programa de Pós-Graduação em Educação) - Universidade de São Paulo, 2006.

SÁ, L. P.; FERREIRA, J. Q.; QUEIROZ, S. L. Os professores de ciências devem ensinar os alunos a argumentar? Encontro Nacional de Pesquisa em Educação em Ciências, 2009.

SÁ, L. P.; QUEIROZ, S. L. Estudo de casos no ensino de química. São Paulo: Editora Átomo, 2009.

SÁ, L.; QUEIROZ, S. L. O. Promovendo a argumentação no ensino superior de química. Química Nova, v.30(8), p. 2035-2042, 2007. 
SÁ, L.; QUEIROZ, S. L. Argumentação no ensino de ciências: contexto brasileiro. Ensaio, v. 13(2), p. 13-30, 2011.

SANTOS, W. L. P.; MORTIMER, E, F.; SCOTT, P. H. A argumentação em discussões sócio-científicas: reflexões a partir de um estudo de caso. Revista Brasileira de Pesquisa em Educação em Ciências, Porto Alegre, v. 1(1), p. 140152, 2001.

SARDÀ, A. J.; PUIG, N. S. Enseñar a argumentar científicamente: um reto de las clases de ciencias. Enseñanza de las Ciencias, v. 18(3), p. 405-422, 2000.

SANNAMED, M. G.; ABELEDO, E. J. F. El practicum ene el aprendizaje de la profesión docente. Revista de Educación, 354, enero-abril, p.47-70, 2010.

SANTOS, W. L. P.; MORTIMER, E. F.; SCOTT, P. H. A argumentação em discussões sócio-científicas: reflexões a partir de um estudo de caso. Revista Brasileira de Pesquisa em Educação em Ciências, v. 1, 2007.

SÃO PAULO/CONSELHO ESTADUAL DE EDUCAÇÃO. Deliberação CEE N 78/08. Fixa normas complementares para a formação dos profissionais docentes em cursos de licenciatura para a educação básica, oferecidos pelos estabelecimentos de ensino superior, vinculados ao sistema estadual ressalvada a autonomia universitária. Publicado no DOE em 04/12/08 Seção I Página 25. Disponível em: <http://iage.fclar.unesp.br/ceesp/cons_ava.php>, 2008.

SÃO PAULO/CONSELHO ESTADUAL DE EDUCAÇÃO. DELIBERAÇÃO CEE No 111/12. Fixa Diretrizes Curriculares Complementares para a Formação de Docentes para a Educação Básica nos Cursos de Graduação de Pedagogia, Normal Superior e Licenciaturas, oferecidos pelos estabelecimentos de ensino superior vinculados ao sistema estadual. Publicado no DOE em 03/02/2012 Seção I - Página 46, Disponível em: <http://iage.fclar.unesp.br/ceesp/cons_ava.php>, 2012.

SASSERON, L. H. E.; CARVALHO, A. M. P. Almejando a alfabetização científica no ensino fundamental: a proposição e a procura de indicadores do processo. Investigações em Ensino de Ciências, v.3(3), p.333-352, 2008.

SASSERON, L. H. E.; CARVALHO, A. M. P. Uma análise de referenciais teóricos sobre a estrutura do argumento para estudos de argumentação no ensino de Ciências. Revista Ensaio - Pesquisa em Educação em Ciências,v.13(3), p.243262, set-dez. 2011a.

SASSERON, L. H. E,; CARVALHO, A. M. P. Construindo argumentação na sala de aula: a presença do ciclo da Argumentação, os indicadores de Alfabetização Científica e o padrão de Toulmin, Ciência \& Educação, v.17(1), p. 97-114, 2011 b. 
SAVIANI, D. Os saberes implicados na formação do educador. In: BICUDO, M. A. V.; JUNIOR, C. A. S.(orgs.) Formação do educador: dever do Estado, tarefa da universidade. São Paulo: Editora da Universidade Estadual Paulista, 1996.

SILVA, M. L. R Desafios dos cursos de formação docente frente às políticas públicas no Brasil. Revista Internacional d'Humanitats, v.24, jan-abr, p. 57-62, 2012.

SIMON, S.; ERDURAN, S.; OSBORNE, J. Learning to teach argumentation: research and development in the science classroom. International Journal of Science Education, v. 28(2-3), p. 235-260, 2006.

SCHÖN, D. A. Educando o profissional reflexivo: um novo design para o ensino e a aprendizagem. Trad. Roberto Cataldo Costa. Porto Alegre: Artes Médicas, 2000.

SOLBES. J.; RUIZ, J. J.; FURIÓ, C. Debates y argumentación en las clases de física y química. Didáctica de las Ciencias Experimentales, n.63, p.65-75, enero, 2010.

SHULMAN, L. Knowledge and teaching: Foundations of the new reform. Harvard Educational Review, v.1(57), p. 1-22, 1987.

VASCONCELOS, S. D.; LIMA, K. E. C. O professor de biologia em formação: reflexão com base no perfil socioeconômico e perspectivas de licenciandos de uma universidade pública. Ciência \& Educação, v. 16(2), p. 323-340, 2010.

VIEIRA, R. D.; NASCIMENTO, S. S. A argumentação no discurso de um professor e seus estudantes sobre um tópico de mecânica newtoniana. Cad. Bras. Ens. Fís., v. 24(2) p. 174-193, ago. 2007.

TARDIF, M. Saberes profissionais dos professores e conhecimentos universitários Elementos para uma epistemologia da prática profissional dos professores e suas consequências em relação à formação para o magistério. Revista Brasileira de Educação, n. 13, Jan/Fev/Mar/Abr, p. 5-24, 2000.

TARDIF, M. Saberes docentes e formação profissional. $11^{\circ}$ edição. Petrópolis: Vozes, 2010.

TEIXEIRA, E. S.; NETO, C. P. S.; FREIRE Jr. O.; GRECA, I. M. A construção de uma argumentação sobre a síntese newtoniana a partir de atividades em grupos. Investigações em Ensino de Ciências, v. 15(1), p. 61-95, 2010.

TOULMIN, S. Os usos do argumento. Tradução Reinaldo Guarany. São Paulo: Martins Fontes, 2001. 375p.

TRINIDAD, O. Producción de argumentaciones escritas en las clases de física. Alambique. Didáctica de las Ciencias Experimentales, n. 63, p. 50-56, 2010. 
VIEIRA, R. D., NASCIMENTO, S. S. Uma visão integrada dos procedimentos discursivos didáticos de um formador em situações argumentativas de sala de aula. Ciência \& Educação, v. 15(3), p. 443-457, 2009 a.

VIEIRA, R. D.; NASCIMENTO, S. S. Uma proposta de critérios marcadores para identificação de situações argumentativas em salas de aulas de ciências. Caderno Brasileiro de Ensino de Física, v. 26(1), p. 81-102, 2009 b.

VILLANI, C. E. P.; NASCIMENTO, S. S. A argumentação e o ensino de ciências: uma atividade experimental no laboratório didático de física do ensino médio. Investigações em Ensino de Ciências, v. 8(3), p. 187-209, 2003.

ZANON, D. A.; OLIVEIRA, J. R. S.; QUEIROZ, S. L. O “saber” e o "saber fazer" necessários à atividade docente no ensino superior: visões de alunos de pósgraduação em Química. Revista Ensaio, v. 11(1), p. 1-20, junho 2009.

ZEICHNER, K. M. A Formação reflexiva de professores, ideias e práticas. EDUCA, Lisboa, 1993.

ZIBETTI, M. L. T.; SOUZA, M. P. R. Apropriação e mobilização de saberes na prática pedagógica: contribuição para a formação de professores. Educação e Pesquisa, v.33(2), maio/ago, p. 247-262, 2007. 


\section{Apêndice 1. Referências dos trabalhos localizados sobre saberes docentes nas principais revistas brasileiras de Ensino de Ciências}

\section{Referências}

Campos, L. M. L., Diniz, R. E. S. A prática como fonte de aprendizagem e o saber da experiência: o que dizem professores de Ciências e de biologia. Investigações em Ensino de Ciências. v. 6(1), p. 79-96, 2001.

Laburú, C. E., Barros, M. A., Kanbach, B. G. A relação com o saber profissional do professor de física e o fracasso da implementação de atividades experimentais no ensino médio. Investigações em Ensino de Ciências. v. 12(3), p.305-320, 2007.

Zanon, D. A., Oliveira, J. R. S., Queiroz, S. L. O “saber" e o "saber fazer" necessários à atividade docente no ensino superior: visões de alunos de pós-graduação em Química. Revista Ensaio, v. 11 (1), p. 1-20, junho 2009.

Baccon, A. L. P., Arruda, S. M. Os saberes docentes na formação inicial do professor de física: elaborando sentidos para o estágio supervisionado. Ciência \& Educação, v. 16 (3), p. 507-524, 2010

Langhi, R. , Nardi, R. Formação de professores e seus saberes disciplinares em astronomia essencial nos anos iniciais do ensino fundamental. Rev. Ensaio. Belo Horizonte , v.12 (2), p.205-224, mai-ago, 2010.

Arruda, S. M., Lima, J. P. C. Passos, M. M. Um novo instrumento para a análise da ação do professor em sala de aula. Revista Brasileira de Pesquisa em Educação em Ciências v. 11(2), p. 139-160, 2011. 


\title{
Apêndice 2- referências dos trabalhos localizados sobre argumentação nas principais revistas brasileiras de Ensino de Ciências.
}

\begin{tabular}{ll}
\hline \hline Referências \\
\hline \hline
\end{tabular} \\ Capecchi, M. C.V.M., Carvalho, A. M. P.; Argumentação em uma aula de \\ conhecimento físico com crianças na faixa de oito a dez anos. Investigações \\ em Ensino de Ciências. v.5 (3), p. 171-189, 2000. \\ Santos, W. L. P., Mortimer, E. F., Scott, P. H. A argumentação em discussões \\ sócio-científicas: reflexões a partir de um estudo de caso. Revista Brasileira de \\ Pesquisa em Educação em Ciências, v. 1 (1), p. 140-152, 2001. \\ Capecchi, M. C.V.M., Carvalho, A. M. P.; Silva, D. Relações entre o discurso do \\ professor e a argumentação dos alunos em uma aula de física. Revista Ensaio - \\ Pesquisa em Educação em Ciências. v 2(2), 2002. \\ Villani, C. E. P., Nascimento, S. S. A argumentação e o ensino de Ciências: uma \\ atividade experimental no laboratório didático de física do ensino médio. \\ Investigações em Ensino de Ciências. v 8(3), p. 187-209, 2003.
}

Monteiro, M. A. A. Teixeira, O. P. B. Uma análise das interações dialógicas em aulas de Ciências nas séries iniciais do ensino fundamental. Investigações em Ensino de Ciências. v. 9 (3), p. 243-263, 2004.

Sá, L. P., Queiroz, S. L. Promovendo a argumentação no ensino superior de Química. Química Nova, v. 30 (8), p. 2035-2042, 2007

Vieira, R. D.; Nascimento, S. S. A argumentação no discurso de um professor e seus estudantes sobre um tópico de mecânica newtoniana. Cad. Bras. Ens. Fís., v. 24, n. 2: p. 174-193, ago. 2007.

Nascimento, S. S.; Vieira, R. D. Contribuições e limites do padrão de argumento de Toulmin aplicado em situações argumentativas de sala de aula de Ciências. Revista Brasileira de Pesquisa em Educação em Ciências. v. 8(2), 2008.

Nascimento, S. S., Plantin, C. Vieira, R. D. A validação de argumentos em sala de aula: um exemplo a partir da formação inicial de professores de física. Investigações em Ensino de Ciências. v.13(2), p.169-185, 2008.

Assis, A., Teixeira, O. P. B. Argumentações discentes e docente envolvendo aspectos ambientais em sala de aula: uma análise. Ciência \& Educação, v. 15 (1), p. 47-60, 2009.

Vieira, R. D., Nascimento, S. S. Uma proposta de critérios marcadores para identificação de situações argumentativas em salas de aula de Ciências. Cad. Bras. Ens. Fís., v. 26, n. 1: p. 81-102, abr. 2009.

Vieira, R. D., Nascimento, S. S. Uma visão integrada dos procedimentos discursivos didáticos de um formador em situações argumentativas de sala de aula. Ciência \& Educação, v. 15 (3), p. 443-457, 2009.

Teixeira, E. S.; Neto, C. P. S.; Freire Jr. O.; Greca, I. M. A construção de uma argumentação sobre a síntese newtoniana a partir de atividades em grupos. Investigações em Ensino de Ciências. v. 15(1), p. 61-95, 2010.

Padilha, J. N., Carvalho, A. M. P. Relações entre os gestos e as palavras utilizadas durante a argumentação dos alunos em uma aula de conhecimento físico. Revista Brasileira de Pesquisa em Educação em Ciências. v. 11(2), p. 25- 
40, 2011.

Sasseron, L. H. Carvalho, A. M. P. Construindo argumentação na sala de aula: a presença do ciclo da Argumentação, os indicadores de alfabetização científica e o padrão de Toulmin. Ciência \& Educação, v. 17 (1), p. 97-114, 2011.

Sasseron, L. H. Carvalho, A. M. P. Uma análise de referenciais teóricos sobre a estrutura do argumento para estudos de argumentação no ensino de Ciências. Revista Ensaio - Pesquisa em Educação em Ciências. v.13 (3), p.243-262, setdez. 2011.

Perez, D. M.; Rebechi, D.; Azevedo, K. L.; Schreiner, P. G. ; Mattia, R. C.; Renata Slowik, R.; Oliveira, O. B. Temas polêmicos e a argumentação do curso de Ciências biológicas. Revista Ensaio - Pesquisa em Educação em Ciências, v.13, n.02, p.135-150, mai-ago, 2011.

Sá, L. P.; Queiroz, S. L. Argumentação no ensino de Ciências: contexto brasileiro. Revista Ensaio - Pesquisa em Educação em Ciências, v.13(2), p.1330, 2011. 


\section{Apêndice 3 - Roteiro para o estágio de observação}

Orientações para a realização do estágio de observação

Observe e reflita sobre os aspectos abaixo mencionados.

- Disposição dos alunos em sala de aula.

- Maneira com os alunos reagem quando o professor pede para que façam exercícios.

- Como o professor realiza a avaliação dos alunos.

- Como os alunos se comportam na presença de alunos deficientes.

- Como o professor interage com alunos deficientes.

- Como a aula é conduzida.

- Reflita como você agiria diante dos problemas enfrentados pelo professor.

- Tenha contato com o material (cadernos de Química do Estado de SP) e a estrutura da escola.

- Como é o comportamento (a fala, organização, interesse pela disciplina) dos alunos em sala de aula.

- O comportamento do professor diante do interesse/ desinteresse dos alunos.

- Que tipo de condições físicas a escola possui e se elas influenciam no sistema educacional.

- Perceba a heterogeneidade dos alunos da sala de aula e observe como o professor lida com ela.

- Qual o nível em que o conteúdo é ministrado aos alunos.

- Há diferenças na maneira em que o professor apresenta o mesmo conteúdo para salas diferentes? Se sim, qual poderia ser o motivo? 
- Dentro de um tema quais são os conteúdos que são escolhidos pelo professor para ser trabalhados com os alunos.

- Quais recursos didáticos são utilizados em sala de aula e como são utilizados. 


\section{Apêndice 4- Orientações à elaboração do projeto de regência}

\section{Orientacões para elaboração do projeto de regência}

As atividades a serem desenvolvidas durante a regência devem criar um ambiente propício para que os alunos do ensino médio argumentem colaborando na construção do conhecimento

O projeto de regência deverá apresentar os seguintes itens:

1) Apontar os assuntos que serão abordados.

2) Apresentar os objetivos que se pretende atingir (considerar, se for o caso, objetivos: procedimentais, atitudinais, de conteúdo).

3) Descrever a(s) estratégia(s) que será(ão) utilizada(s).

4) Justificar a escolha da(s) estratégia (s) que será(ão) empregada(s).

5) Descrever o material necessário para a regência.

6) Descreva que estratégia pretende desenvolver na sala de aula para promover a argumentação de maneira a colaborar na construção do conhecimento.

7) Justificar a escolha da estratégia a ser utilizada na perspectiva da promoção da argumentação dos alunos do Ensino Médio.

8) Apresentar a proposta de avaliação.

9) Apresentar cronograma de desenvolvimento do projeto.

10) Elaborar e anexar plano de aula para cada uma das aulas que serão ministradas.

11) Citar as referências bibliográficas. 
Apêndice 5- Ficha para anotações das apresentações de compartilhamentos de experiências dos licenciandos.

Atividade de reflexão da regência - Ficha do Tales

Apresentação Rose

Apresentação João

Apresentação Beatriz

Apresentação Paula

Apresentação Pedro 


\section{Apêndice 6- Roteiro da entrevista realizada com os licenciandos.}

\section{Bloco 1: Processo de formação}

1) Que aspectos você considera que foram fundamentais no seu processo de formação ao longo do curso de licenciatura para a sua futura atuação docente?

2) Para você quais foram às contribuições que a disciplina de Prática do Ensino de Química trouxe para a sua futura atuação docente?

3) Quais atividades da disciplina que você mais gostou, quais que mais aprendeu? Justifique e dê exemplos concretos. (saberes docentes, formação de Professores de Química, Mapas Conceituais, Movimento das Concepções Alternativas, As sete visões deformadas sobre o trabalho científico, História da Química no ensino de Química, Tendências atuais e Pesquisas no Ensino de Ciências, Aprendizagem Cooperativa e Argumentação.

4) Para você o que é ser um bom professor?

5) Quais os conhecimentos necessários para ser um bom professor?

6) Se você tivesse que destacar um momento no curso de licenciatura fundamental para a sua formação como docente, qual seria?

\section{Bloco 2: Experiências em relação à argumentação}

7) Você tem lembrança de atividades argumentativas ocorridas na sua vida escolar? E fora da escola?

8) Em que situações você acha que argumenta?

9) Como você se sente quando precisa argumentar?

10) Você já teve outras experiências como docente? Se sim em alguma delas trabalhou com atividade argumentativa? Quais?

11) Você tinha ideia de que se poderia trabalhar a argumentação com os alunos?

\section{Bloco3: Concepção sobre atividades argumentativas}

12) Para você o que é a argumentação?

13) Você acha importante trabalhar com atividades argumentativas em sala de aula? Justifique.

14) Que benefícios você acredita que a argumentação pode trazer para a formação dos estudantes?

15) O que você acha que dificulta a argumentação dos alunos? 


\section{Bloco 4: Elaboração da regência}

16) Que atividade você desenvolveu na regência para promover um ambiente da Argumentação em sala de aula?

17) Qual foi o critério que você utilizou para escolher a atividade para promover a argumentação dos alunos?

18) Você acha que a atividade que escolheu promoveu a argumentação dos alunos? Por quê?

19) Que critério você utilizou para concluir que os alunos argumentaram ou não?

20) Quais elementos específicos da disciplina foram mais significativos (principalmente para a argumentação) e o que foi feito, em termos de processos, para ajudar no desenvolvimento das atividades argumentativas?

\section{Bloco 5: Impressão do desenvolvimento da regência}

21) Como você se sentiu ao ter que fazer uma aula com foco na argumentação?

22) Você usaria atividades argumentativas novamente? Usaria da mesma forma? Explique.

\section{Bloco 6: Reflexão em relação à regência}

23) De que forma você avalia a sua regência?

24) Se você pudesse refazer a regência o que mudaria?

25) Você acredita que a forma como conduziu a sua regência possibilitou que os alunos argumentassem? Por quê?

26) A(s) estratégia(s) utilizada por você atendeu suas expectativas? Justifique.

27) Como se deu a participação dos alunos durantes as aulas? e a receptividade dos mesmos frente às estratégias utilizadas para promover a argumentação?

28) Na sua concepção, quais foram às principais funções que a atividade argumentativa deveria assumir na sua regência? Você acha que essas funções foram cumpridas?

29) Quais dificuldades você encontrou para implementar a atividade argumentativa em sala de aula? 
Bloco 7: Saberes docentes elaborados no processo de desenvolvimento e execução da regência

30) O que você acha que aprendeu ao longo do processo de elaboração e execução da regência com foco na argumentação para sua futura atuação como docente?

31) Para você quais são os conhecimentos necessários a um professor para desenvolver uma atividade argumentativa?

Bloco 8: Pretensões futuras

32) Quais são as suas pretensões futuras profissionais?

Bloco 9: Visão geral da prática da disciplina Prática de Ensino

33) Você acha que ter feito a disciplina de Prática do Ensino de Química fez diferença na sua formação como futuro professor? 